كلية اللغة العربية بأسيوط المجلة العلميسة

الإسطاج النموي' ( تعدد المدلول والمقابل )

إعداد

د/ صابر حامد عبدالكريم

أستاذ اللغويات المساعد فى كلية اللغة العربية بأسيوط

( العدد السادس و الثلاثون الجزء الثالث V V ) 


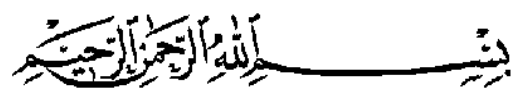

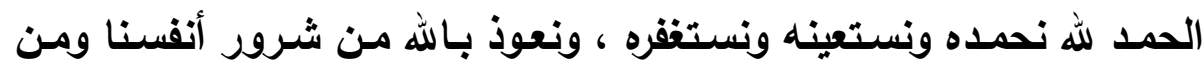

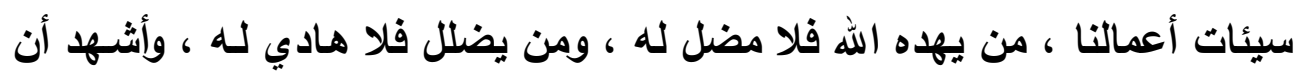

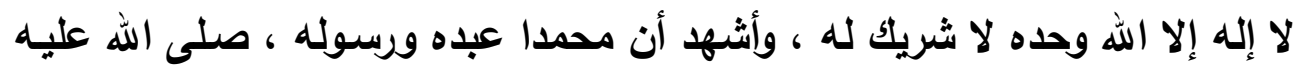
وعلى آله وصحبه وسلم ، ورضي عن صحابته أجمعين .

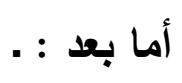

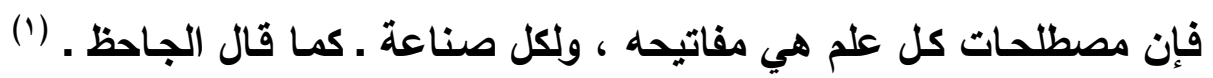

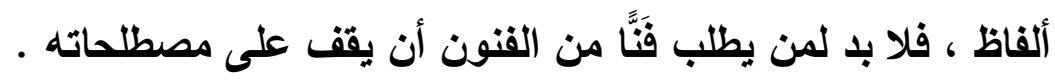

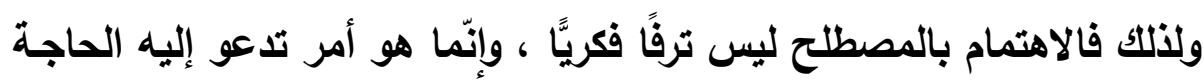

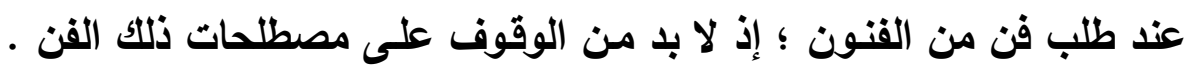

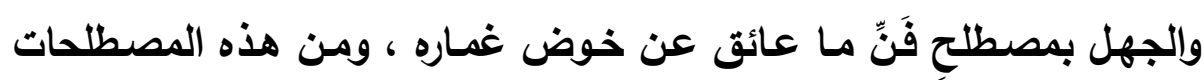

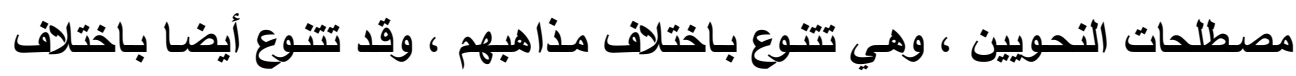

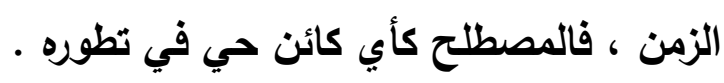

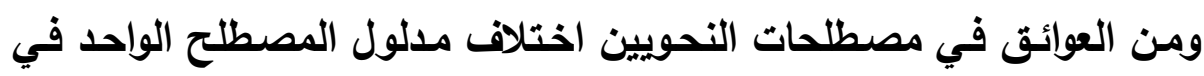

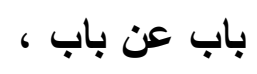

كذلك قد يكون لهذا المصطلح مقابل فيختلف ذلك المقابل تبعًا لمدلول ذلك في

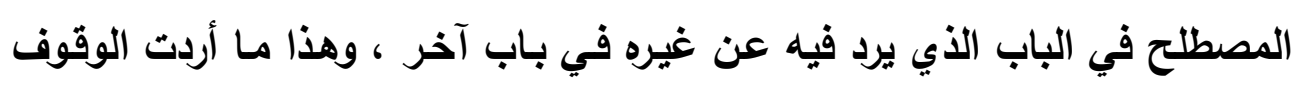

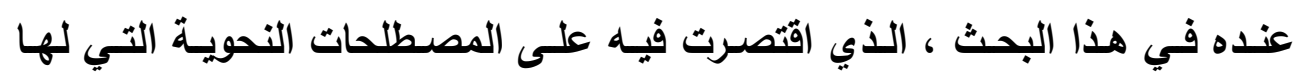

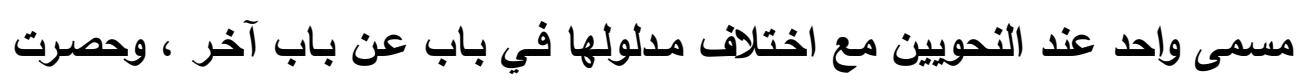
مقابلها في كل بـاب ، وفصلت القول في مدلول المصطلح ومقابلـه ، والأحكام 
المتعلقة بهما ، ولم أتعرض للمصطلح الأي لم يرد في أكثر من باب ، أو الذي لم يختلف مدلوله ، أو الأي لم يتعدد مقابله ـ ـوجاء هذا البحث في:

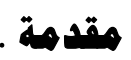

وتمهيد : تكلمت فيه عن المصطلح : معناه ، ونشأته ، وأنواعه ، وتعدده. ثم ثلاثة مباحث : المبــث الأول : عن مصطلح المفرد في أبـواب : الكلمـة والكـلام ، والإعراب والعلم،والخبر والحال والنعت،و "لا" النافية للجنس،والتمييز،والنداء،والعدد . المبمث الثاني : عن مصطلح المتصل في بابي : الضمير ، والاستثناء .

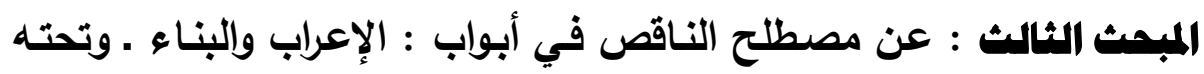
الاسم المنقوص ، والنقص في الأسماء الستة . ، والمعرفة والنكرة ، والنواستخ .

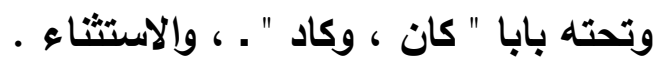

ثم ختمت البمث بخاتمة ذكرت فيها ما توصلت إليه ، وما أوصي به . . وأرجو أن أكون قد وُفِّهُتُ ، وجزى الله خيرا من قرأ هذا البحث فوضـع يـدي على خطا وجده أو توجيه لنَأََْْى لآه . وأسـأل الله ـ تعالى ـ أن يوفقتي أنـا ، أو غيري لاراسـة المصطلحات الصرفية حتى تكتمل دائرة مصطلحات هذا الفن .

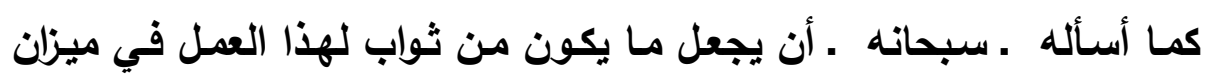

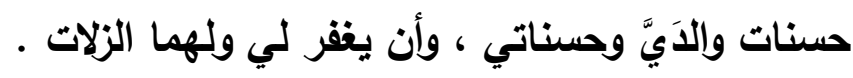
وأختم بمـا قاله الله . عزّ وجلّ . حاكيًا عن نبيه شعيب ـ ـ على نبينا وعليه

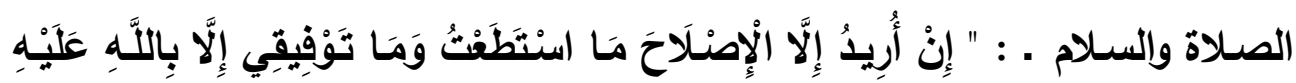

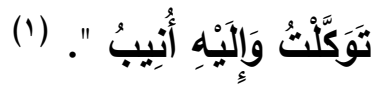

$$
\text { (1) من الآية (^^) في سورة " هود " . }
$$




\section{الدراسات البابقة}

اهتم الباحثون بالمصطلح من الناحية التاريخية،ومن جهة تطوره ، واختلافه باختلاف الزمن ، والفن الأي يرد فيه ، والمذهب الذي ينتمي إليه واضع المصطلح. ومن الدراسات النحوية التي عالجت جانبا من هذه الأمور :

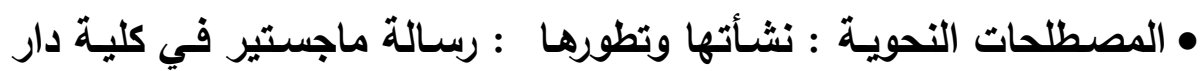

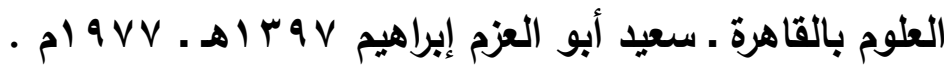

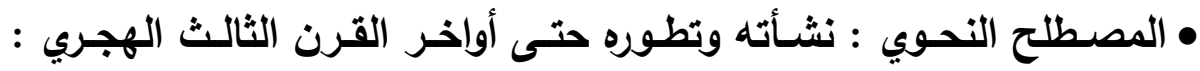

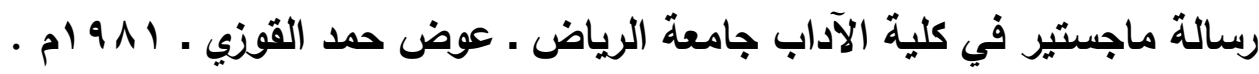

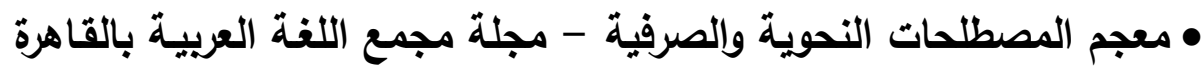

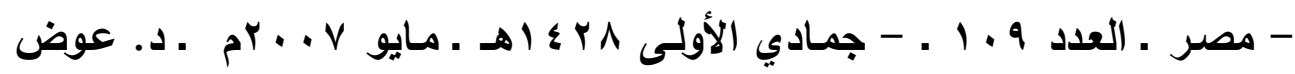
حمد القوزي مديز

• المصطلح النحوي دراسة نقدية تحليلية - أحمد عبد العظيم عبد الغني الناشر دار الثقافة للنشر والتوزيع • • معجم المصطلحات النحويـة والصـرفية - محمد سـمير اللبدي - مؤسسـة الرسبالة.

• المصطلح النحوي عند الفـراء في معساني القـرآن - رسـالة ماجستير في جامعة الموصل . حسن أسعد محمد . 991 ام . • مصسطلحات علـم أصسول النحـو دراســة وكثـاف معجمـي - أثـرف مـاهر

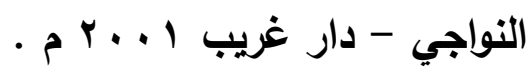

• المصطلح العلمي في اللغة العربية : عمقه التراثي ويعده المعاصر م رجاء

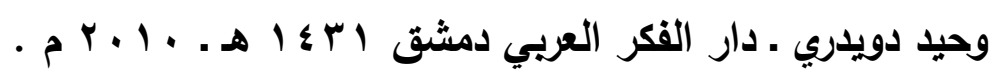

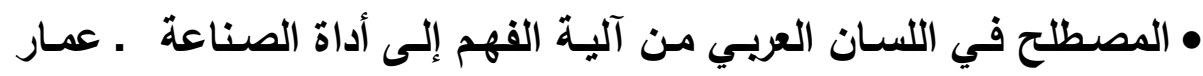

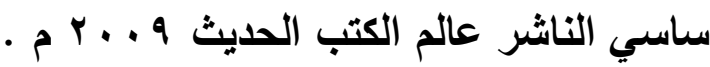


• من قضايا المصطلح اللغوي العربي ـ مصطقى طاهر الجنادرة ـ عالم الكتب

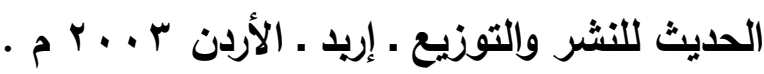

وهناك مؤلفات مشهورة في الاصطلاحات استفلت منها في التمهيد : - الكليات - أبو البقاء الكفوي - مؤسسة الرسالة . - كثاف اصطلاحات الفنون - التهانوي .

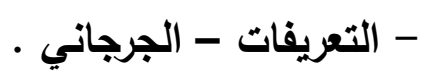

- دستور العلماء - عبد النبي بن عبد الرسول .

ويعد أن انتهيت من إعداد هـا البحث توصلت إلسى أن هنـاك بحثا يـوحي عنوانـه بقرب بحثي هذا منـه ، وهو " تعدد المصطلح وتداخله : قراعة في التراث

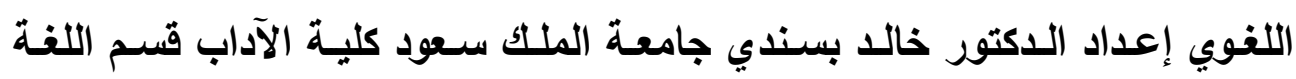

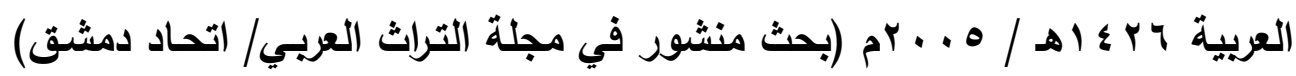

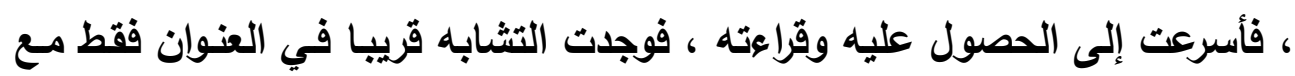

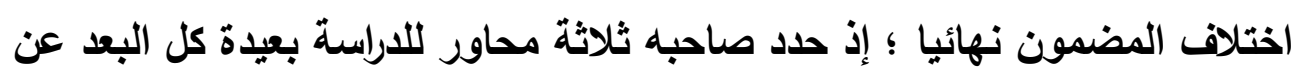
دراسـتي ، وهذه المحاور كمـا نص صـاحب البحث في الصفحة الأولى ( ملخص (البحث ) (

( ) تعدد المصطلح وتداخله للمفهوم الواحد :

نحو إطلاق العلماء مصطلحات ( الاستغناء وسد المسد والاكتفاء ) ، رغم أن الاستفناء يختلف في طبيعته وحكمسه ومواضعه عن المصطلحين الأخيرين ، لكنّ الكّاء

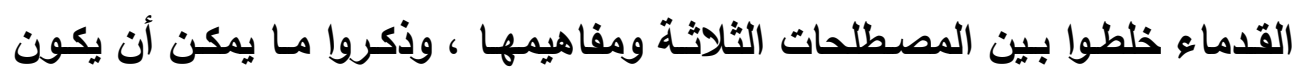

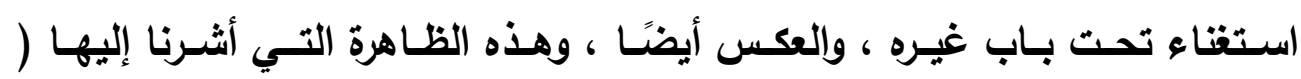

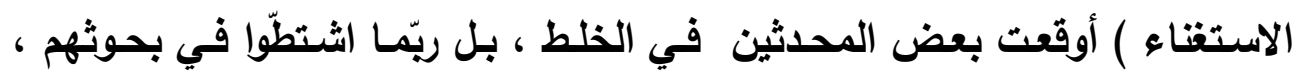

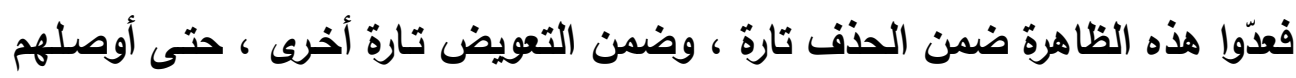
ذلك إلى عدّها من قوانين التحويل اللغويـة الحديثة التي توصّل إليها تشومسكي . ونحو إطلاق سييويه مصطلح ( الخبر ) للالالة على الحال إضـافة إلى مصطلح 
الحال ، ونحو إطلاق سيبويه مصطلح ( الصفة والنعت )على مفهوم واحد ، وإطلاق

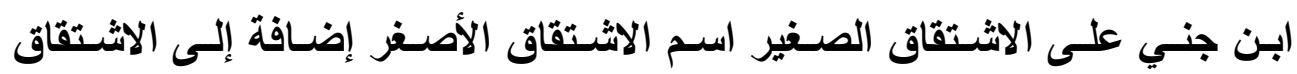

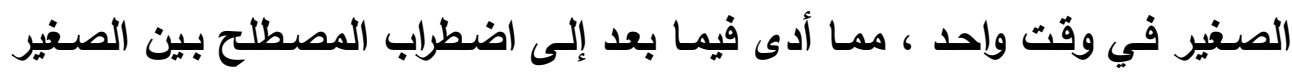

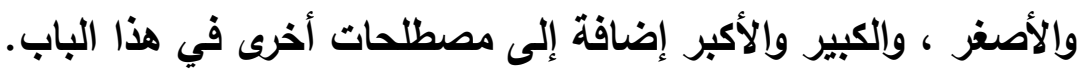

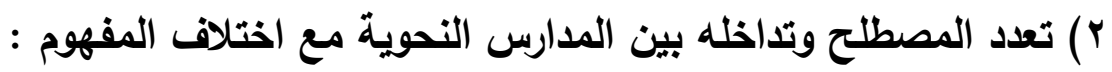

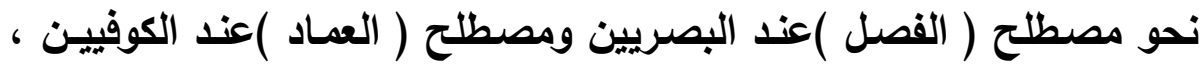

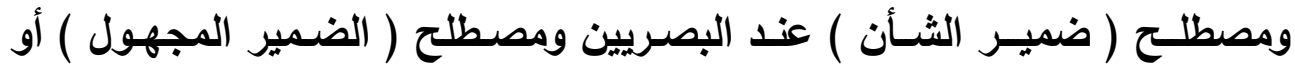

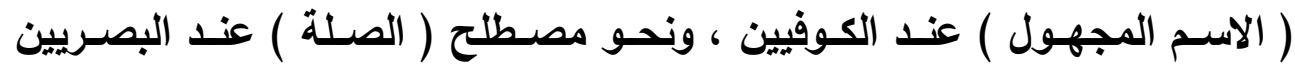

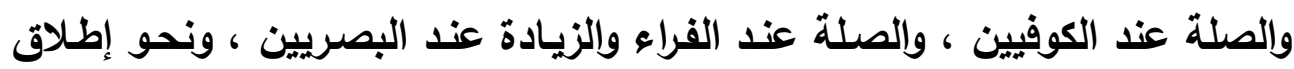

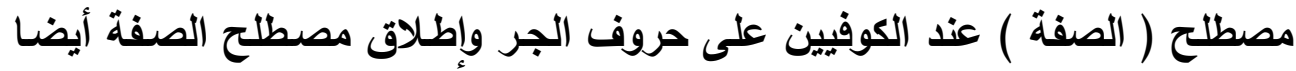
عند بعض الكوفيين على ظرفي الزمان والمكان .

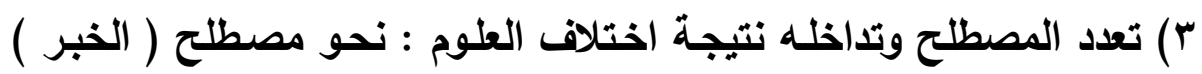
ومفهومه عند النحويين ، ومصطلح الخبر ومفهومـه عند البلاغيين ، ونحو تداخل

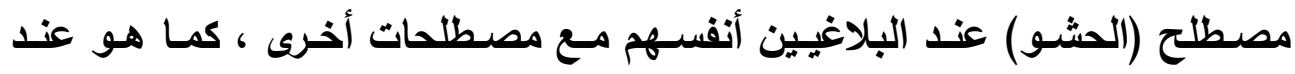
النحويين أيضًا . النئرا 


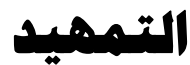

المصطلحات هـي مفاتيح العلوم ـكما قال الخوارزمي ـوقد قيـل إنّ فهـ المصطلحات نصف العِّم ؛ لأنّ المصطلح هو لفظ يعبر عن مفهوم ، والمعرفة مجموعة من المفاهيم التي يرتبط بعضها ببعض .

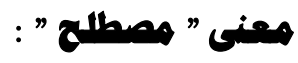
المصطلح في اللغة مـأخوذ من مـادة " ص ل ح " التي تدل على التصـالح • والتوافق

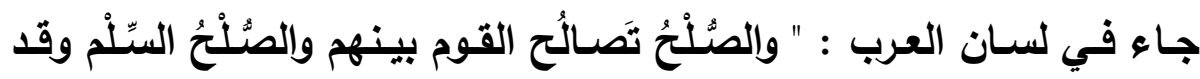

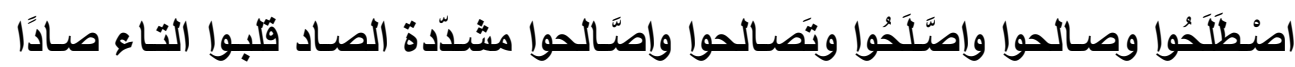
وأَدُغموها في الصاد بمعنى واحد ـ " ( ) ومن هنا فكأن المصطلح يعني أنه حدث خلاف عند إطلاق اسم على مسمَّى ما ، ثم تم توافق واصطلاح على هذا الاسم . وامـا المعنى الاصطلاحي فله صلة بـالمعنى اللغوي للمـادة ، ويفيد أن القوم اختلفوا عند ظهور مدلول جديد على تسميته فأعطاه كلٌّ منهم اسمًا إلى أن صسار اتفاق واصطلاح على تسمية واحدة لذلك المدلول . ومن هنا فالمصطلح عرفيّا عبارة عن اتفاق أهل علم من العلوم أو صناعة

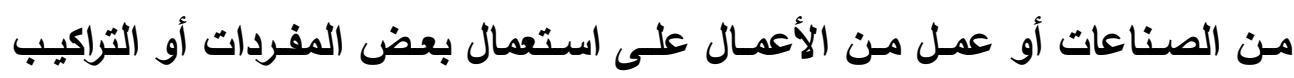

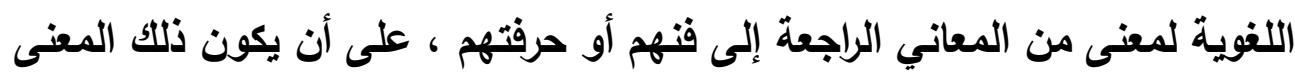

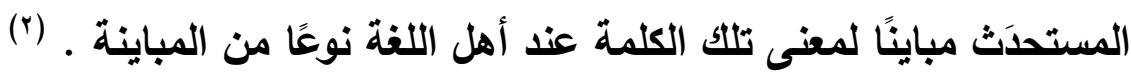


وهذه المصطلحات لا توضـع ارتجـالًا ، بـل لابـ في كل مصطلح من وجود

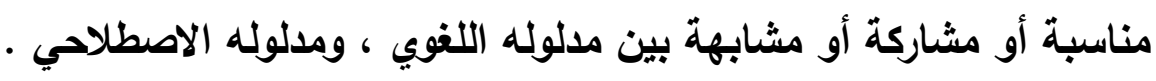

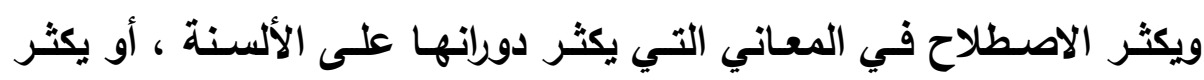

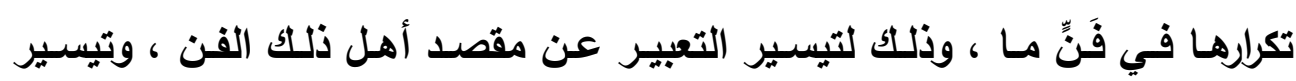
إفهامهم المخاطَبين .

قال ابن جنـي : " ... وذلك كأن يجتمع حكيمـان أو ثلاثة فصاعدًا فيحتاجوا

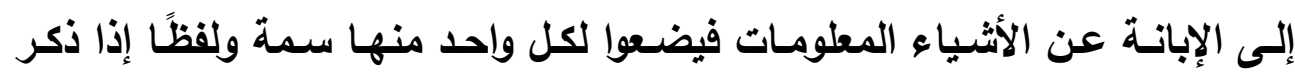

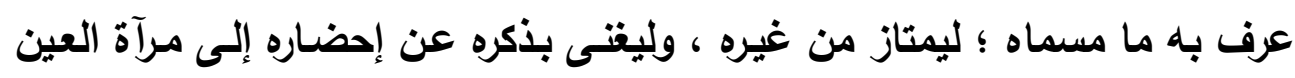

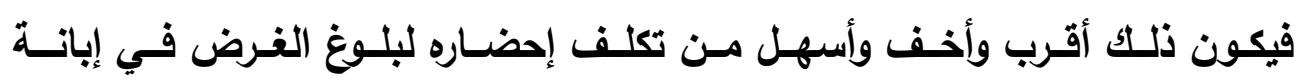

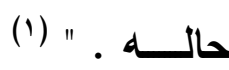

وقد تعددت الأقوال في تعريف " المصطلح " في الاصطلاح ، ففي كتاب

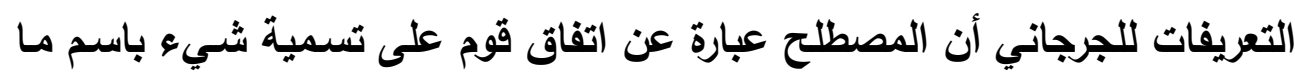

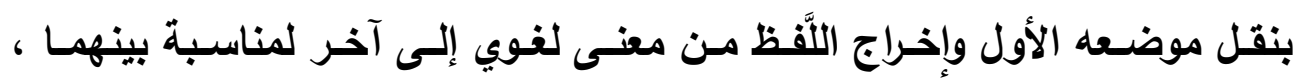

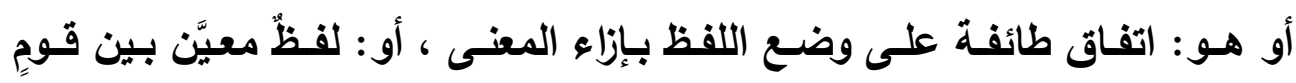

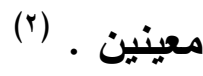
وقال أبو البقاء في الكليات : " الاصطلاح هو اتفاق القوم على وضع الثـيء

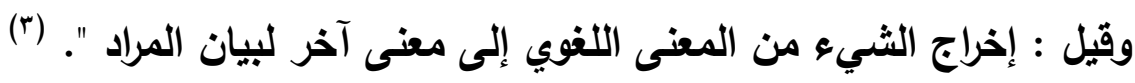

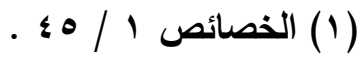

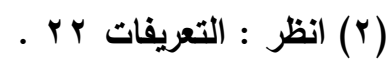

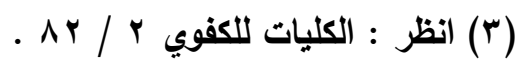


وقـال القـاري في " شـرح نخبـة الفكر " مبينًا معنى عبـارة ابن حجر " في اصـطلاح أهـل الحـديث " : أي في عـرفهم ، وهـو تـوافقهم على اسـتعمال ألفــاظ

مخصوصة يتداولونها على وجه التعارف فيما بينهم،كما اصطلحوا عليها. (1) وقيل:هو اللفظ المختار للالالة على شيء معلوم ليتميز به عما سواه ـ (؟) ولفظ مصطلح مصدر ميمسي أو اسـم مفعول من الفعل الـلازم " اصطلح " وكان حق اسـم المفعول هنـا أن يستعمل معسه جـار ومجرور لينوب عن فاعلـه ،

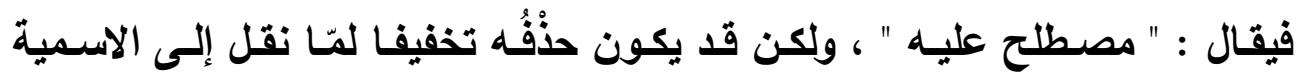
الخالصة لتخصيصه بهذا المدلول الجديد ، فصار كالعلم المـأخوذ من الوصف في نزع الوصفية منها ، وعدم تحمله للضمير • ومفهوم المصطلح يتضمن ثلاثة عناصر : الاتفاق ، والطائفة المخصوصة ، والشيء المخصوص الأي يعني اللفظ والمفهوم •

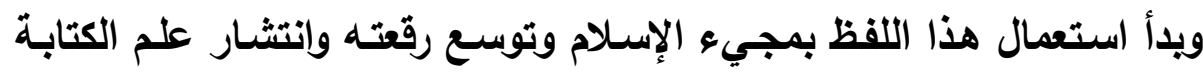
وضرورة المسلمين الملحة إلى تدوين كل ما يتعلق بالشرع ، فظهر من هذه الحركة علم الحديث الأي عرف ب " علم المصطلح " . وسماه أهل الحديث هذه التسمية لأنّه علم اهتم باصطلاحات أهل الحديث من تعريف وتبيين وإيضاح لما كانوا قـ اصطلحوا عليه من ألفاظ في هذا العلم . ولعل أول من اهتم بعلم المصطلح جابر ابن حيان المتوفى سنة . . rهـ في كتابـهـ " الحـدود " ، وتتـاول فيـه المصـطلحات الكيمائيـة والطبيـة ، وأراد بالحـدود المصطلح

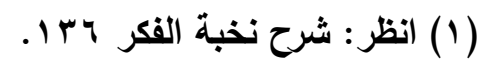

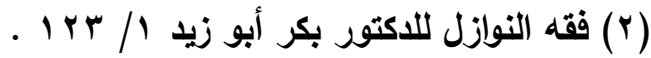


ثـم كـان أبـو حساتم الـرازي المتـوفى سـنة ب r بهـ في كتـاب " الزينـة في

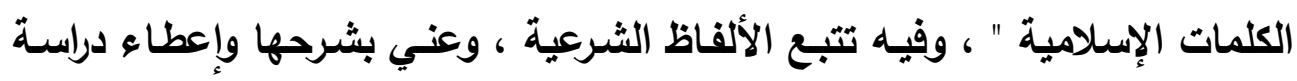
عنها

ثم " الفارابي " المتوفى و وبه في كتابه " الألفاظ المستعملة في المنطق " والخوارزمي المتوفى rAV هـ " في كتابـه " مفاتيح العلوم " ، وابن فارس المتوفى له هو سهـ في كتابـه " الصـاحبي " الذي عقد فيسه بابـا سـماه بالأسباب الإسـلامية ، ومـراده بالأسباب الإسـلامية المصطلحات ، والميداني المتوفى اسه هـ في كتابـه

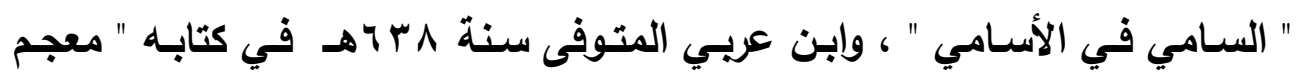
المصطلحات الصوفية " ، والجرجاني المتوفى سنة 1 ا 1هـ في كتابه " التعريفات ".

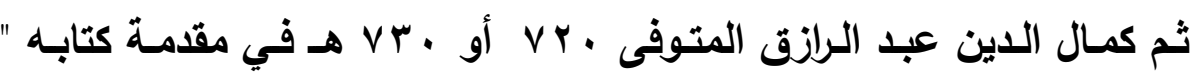
اصطلاحات الصوفية " ، وابن خلدون ^ ـ ^ هـ في الفصل الحادي والخمسين من مقدمته . (1)

\section{أنواع الإمطات :}

تتــوع المصطلحات حسب الفن الذي توضـع لـه تلـك المصطلحات ، فهنـاك مصطلحات فقهية ، ومصطلحات حديثية ، ومصطلحات في النحو ، ومصطلحات في علم البلاغة ، ومصطلحات في الأدب ، ومصطلحات في التاريخ ، ومصطلحات في القلسفة ، ومصطلحات في الطب ، ومصطلحات في الهندسـة ، ومصطلحات في ، الكيمياء ، والفيزياء ، والقانون ، وعلم الحيوان ، وعلم التبات ، وعلم الرياضيات

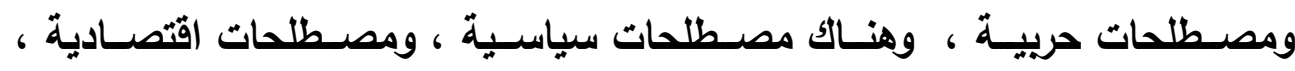
وجغرافيـة ، وجيولوجيـة ، وغيرهـا مسن العلوم فلكل فن مصسطحات تعسارف عليهـا

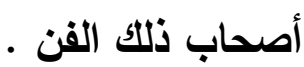

(1) انظر : مجلة لسان العرب . العدد الثامن والأريعون 1 . 


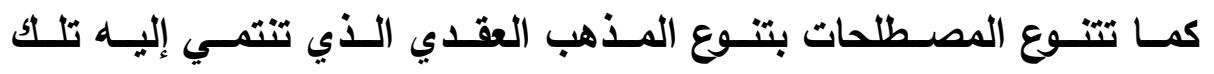

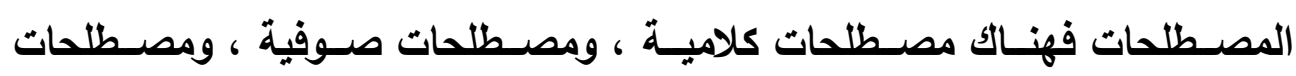
شيعية.

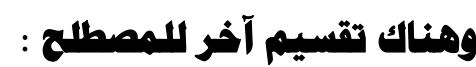

فهناك مصطلح الرمز بالحرف ، كما هو لدى المحدثين في ألفاظ التصحيح والتضعيف ، والعزو والتخريج ، وأيضا علماء الجبر والكيمياء والهندسة ونحوها ، ومصطلح الأرقام والحروف الأبجدية ، ومصطلح الرمز بالثكل والرسم كما هو للى ، علماء الرياضيات . (1) واختلاف الاصطلاحات قد تكون سببا في صعوية التحصيل ، ولذا وجب على طالب العلم الوقوف عليها ، ومعرفة دلالتها في العلم الذي يطلبه ، وطلبها من أهل

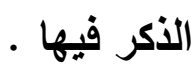

يقول ابن خلاون : " والاصطلاحات أيضا في تعليم العلوم مخلّطة على المتعلّم

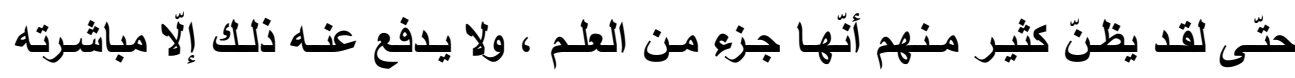
لاختلاف الطّرق فيها من المعلّمين ، فلقاء أهل العلوم وتعدّد المشـايخ يفيده تمييز الاصطلاحات بما يراه من اختلاف طرقهم فيها فيجرّد العلم عنها ويعلم أنّها أنحاء تعليم وطرق توصل وتنهض قواه إلى الرّسـوخ والاستحكام في الملكات وتصـحّح

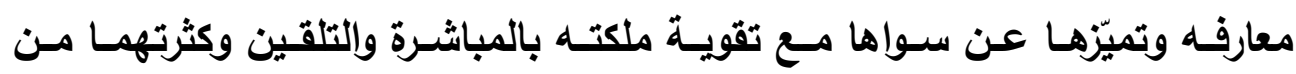

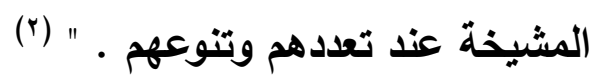

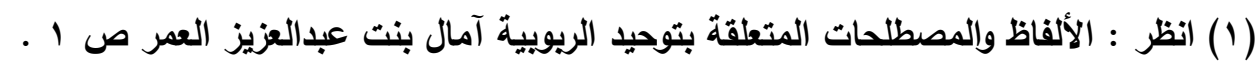

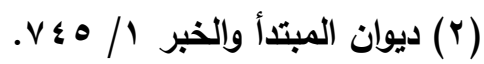


ظمهر الإسطاج النموي :

إذا كان تأسيس النحو قد بـأ على يد البصريين فإنـه مـن الطبعي أن تكون بايـة وضـع المصطلحات على يـهم ، وإن كانت المصطلحات حينئذِ لـم تصل إلى مرحلة النضج التي هي عليه الآن .

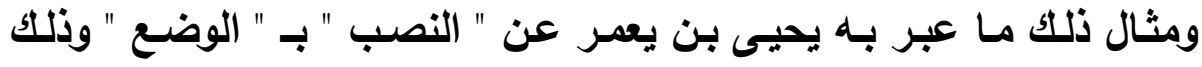
عندما قال لله الحجاج : خبرّنى عنّى هل ألحن ؟ فسكت ، فقال : أقسمت عليك ، فقال : أما إذ سألتتى أيها الأمير فإنك ترفع ما يوضع ، وتضع ما يرفع . (1) ومن النحاة اللذين كان لهم الفضل في ذلك أيضا عبد الله بن أبي إسحاق

الحضرمي (r) (1).

ويذكر أن أول من وضع المصطلح النحوي هو أبو الأسود الدؤلي ، وقد أشـار إلى ذلك ابن النديم معتمدًا على ذكره لمصطلحات مثل الفاعل والمفعول والفتح والكسـر ، كمـا أنـه أطلق كلمـة " النحو " على هذا العلـم اقتباســا مـن كلمـة أمير المؤمنين علي بن أبي طالب ـ رضي الله عنه ـ ("). لكن البداية الحقيقية للمصطلح النحوي بصورته الناضجة كانت عند الخليل وسيبويه وذلك في كتاب سيبويه الأي يمثل خلاصة علم الخليل . وكان المصطلح في كتاب سيبويه عبارة عن اللفظ الدال على معنى نحوي محدد كالاسم ، والفعل ، والفاعل ، والمفعول ، والرفع ، والنصب ، دون ذكر تعريف دقيق لمثل هذه المصطلحات ، وريما اكتفى سيبويه في توضيح الباب الذي يتكلم عنه بذكر أمثلة توضحه . مله

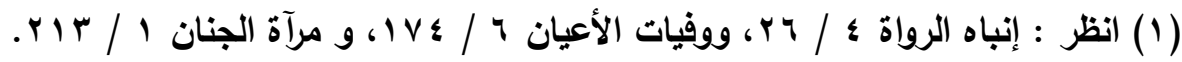

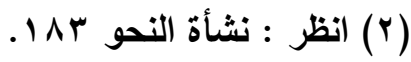

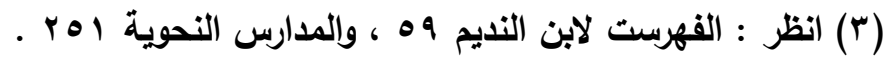


ثم توافرت جهود النحاة من بعده حتى وصل المصطلح النحوي إلى مـا هو عليه الآن - من مون فبعد سيبويه ظهر نحاة كبار ارتقوا بالمصطلح النحوي البصري ، منهم قطرب والأخفش الأوسط ، والجرمي ، والمازني ، والمبرد . كما ظهر في الكوفة نحاة منهم الكسـئي ، والفراء ، وثُعب الذين حاولوا أن ، الن ، يصوغوا آراءهم بمصطلحات جديدة . وإن كانت المصطلحات التي وضـعها البصريون هي التي سـادت للدى نحساة بغداد ، ومصر ، والأندلس ، ومن بعدهم · : تعدد الإم

وقد تعدد المصطلح للمفهوم الواحد ، كما نجد ذلك في تسميتهم " لاسم النكرة الأي يكون بمعنى " من " ، مبينا إبهام اسم أو نسبة " ، فقد أطلقوا عليه أكثر من لن

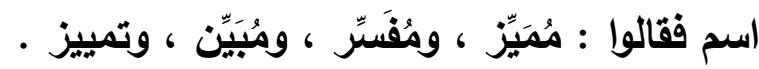

وقد يتعدد المصطلح لاختلاف المدرسـة النحويـة وذلك كما في تعبيرهم عمـا يقوم مقام الفاعل بعد حذفه وتغير صورة الفعل ، فقد عبر البصريون عنه بـ " نائب القاعل " في حين يعبر عنه الكوفيون بـ " ما لم يُسَمَّ فاعله " . وكذلك التعبير بما لا يدخله التنوين ، ولا الجر بالكسرة بـ " مـا لا ينصرف "

عند جمهور النحاة ، في حين يعبر عنه البغداديون بـ " ما لا يُجْرَى ". (1) وقد وضـع المصطلح ليدل على صورة محددة في الفن الذي يوضـع فيها ، ولألك كان الأولى ألا تتعدد دلالته .

(1) انظر : شرح المفصل لابن يعيش 170 
ولكنتـا نجد مصطلحات مشتركة بين علوم مختلفة ، ففي العريبة نجد مثتلا

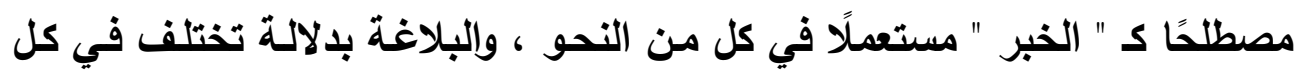

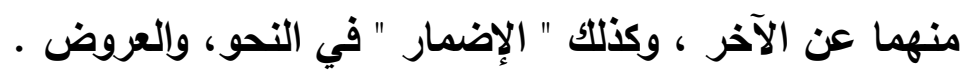

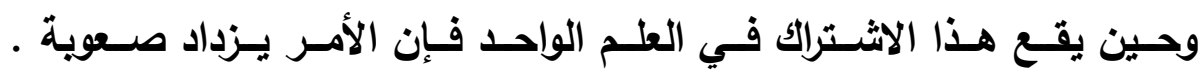

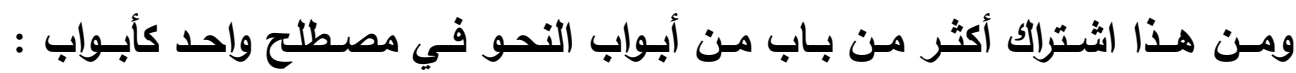

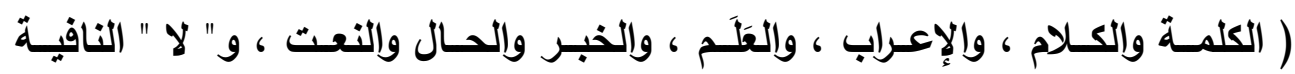

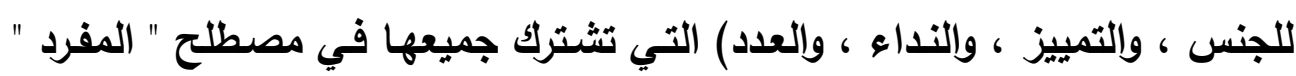

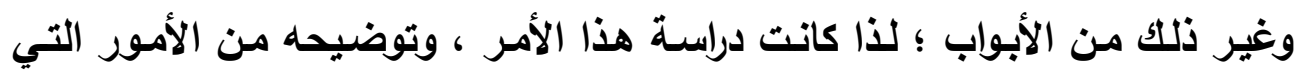
يجدر الاهتمام بها في كل فن من فنون المعرفة . 


\section{المبسث الأول}

\section{المفرد}

المفرد في باب الكمبمة والكلامم :

وهو مشـارك في هذا الباب لمصطلح الكلمـة في أحد إطلاقيها ، فهي تطلق

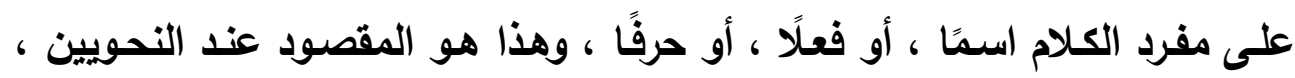
وعلى الكلام التام ، وهذا إطلاق لغوي .

قال " ناظر الجيش " : " الكلمة : تقال في اللغة بطريث الاشتراك لمعنيين :

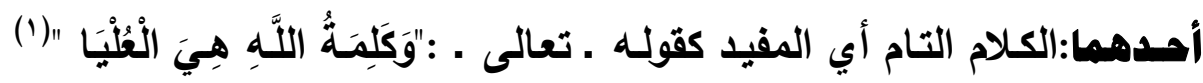
وكقوله ـ صلى الله عليه وسلم ـ " الكلمة الطيّبة صدقة "(r) ، و أصدق كلمة قالها شاعر كلمة لبيد (r)

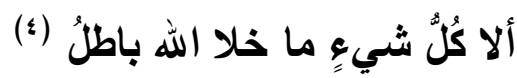

ثانيهما: أحد مفردات الكلام وهو الاسم وحده أو الفعل وحده أو الحرف وحده وهذا هو المصطلح عليه في علم النحو " (0).

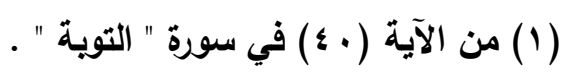

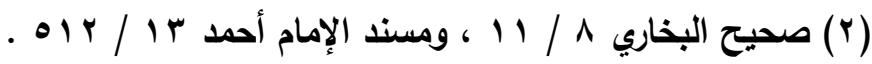

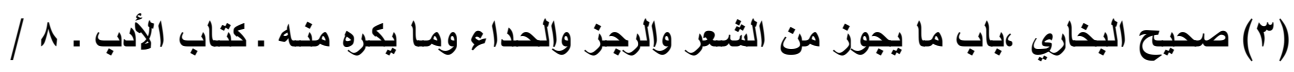

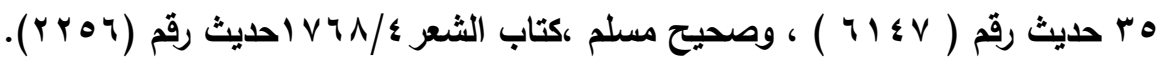

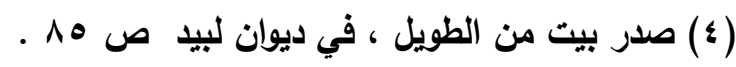

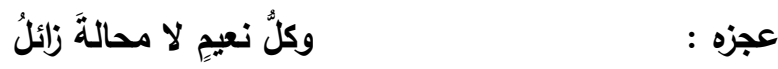

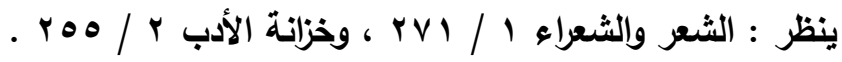

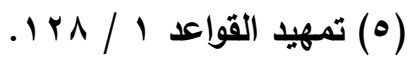


• والمفرد في هذا الباب هو ما لا يلاُّ جزؤه على جزء معناه كـ " زيلـ " ، فلا

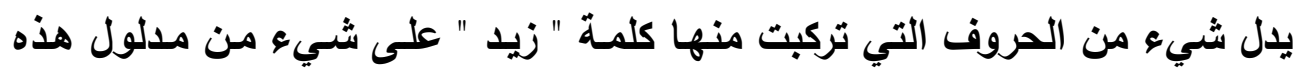
الكلمة.

والمراد بالإفراد أن الكلمة بمجموعها وضعت لذلك المعنى دفعة واحدة ، ثم إذا

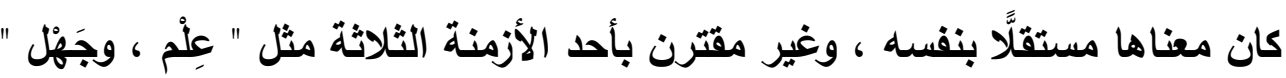

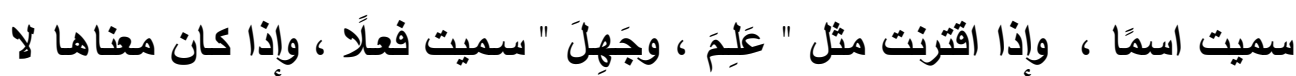

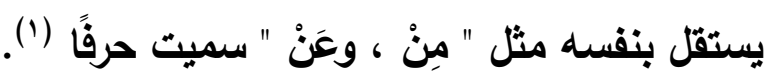

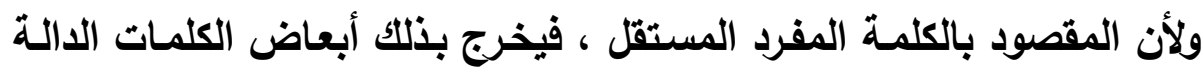

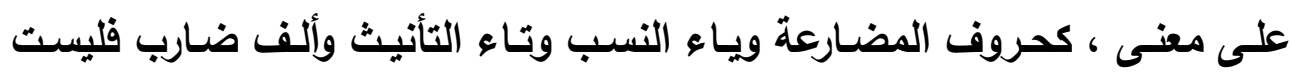

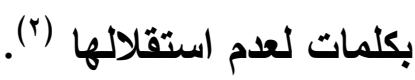
ويلذخل فيه مثل " ضرب " ، وغيره من الأفعال ، مـع أنـه داخل في تعريف

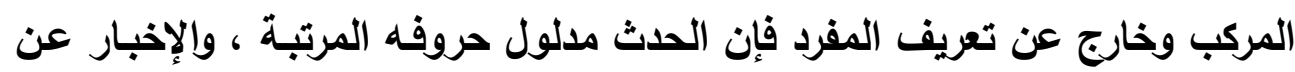
كون ذلك في الزمن الماضي مدلول وزنه الطارئ على حروفه ، والوزن جزيع اللفظ ؛

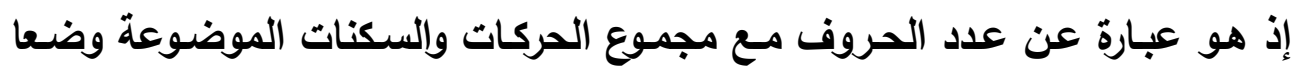
معيّا ، والحركات مما يُتلفظ به ، فهو حينئذ كلمة مركبة من جزأين يدل كل منهو منهما

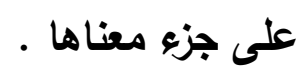

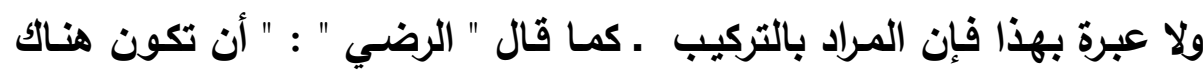

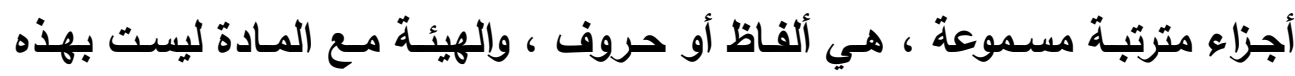
المثابة ، بل الجزآن مسموعان معا ، فلا يلزم التركيب (ץ).

(1) انظر : مفتاح العلوم للسكاكي ص 9 . .

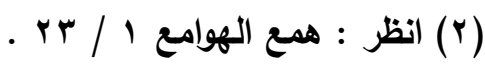

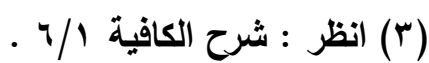




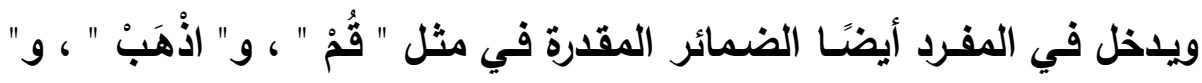
انْطَّقُ " ، لأنها وإن لم تكن كلمات بالفعل إلا أنها كلمات بالقوة . قال في التصريـح : " والضمائر المستترة ألفاظ بالقوة،ألا ترى أنها مستحضـرة

عند النطق بما لابسها من الأفعال استحضارًا لا خفاء معه ولا لبس" (') ولو ركبت كلمة من اسمين مثل " بعلبك " ، أو حرفين مثل " لولا " ، ثم سُمِّيَ

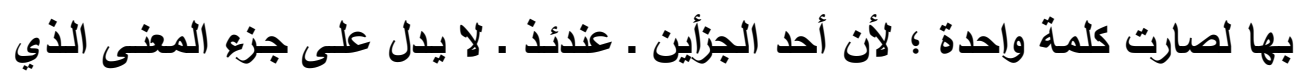

هو الذات المسماة بتلك الكلمة ، ومن هنا فتكون هذه الكلمة من قبيل المفرد (؟). وهو أخص من القول ؛ لاخوله تحته ؛ إذ المفرد هو الكلمة التي هي نوع من

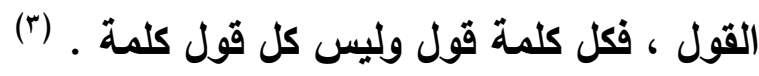

\section{بإ)}

• ويقابل المفرد هنا المركب ، ويشمل الكلم ، والكلام ، والجملة . فالكلم : ما تركب من ثََلاث كلمـات فصـاعدا أفاد ، أم لـ يفد ، مثل " قد قام

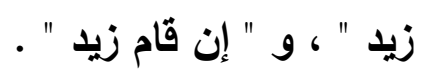

والكلام : ما تضمن من الكلام إسنادا مفيدا مقصودا لاتـه (๕) ، مثل " زيــ

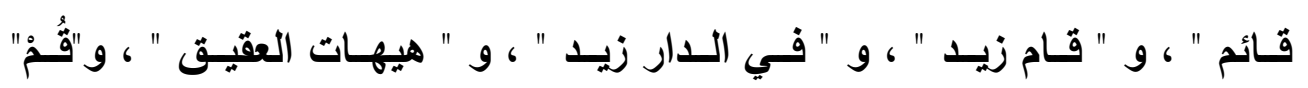




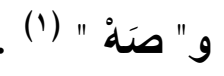

والمركب هنا هو ما دل جزؤه على جزي معنـاه ، و قد يكون بوضـع كلمـة مـع

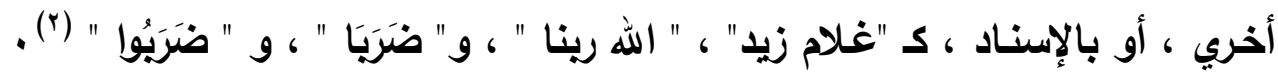

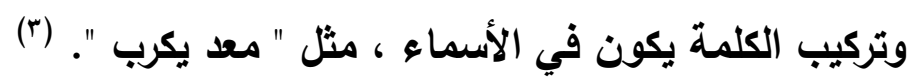

وفي الحروف ، مثل " لولا " ، ولا يكون في الأفعال ، ومـا أخذت منهه ـ وهو

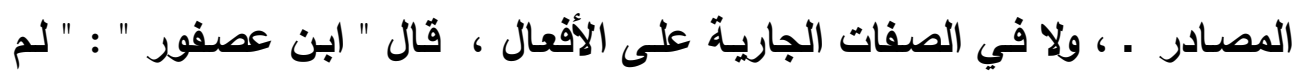

يوجد في الأفعال ما هو مركب " (؛ ) .

والتركيب الإسنادي لا يتأتى إلا من اسمين ، أو من اسم وفعل (•) .

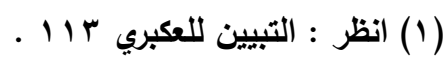

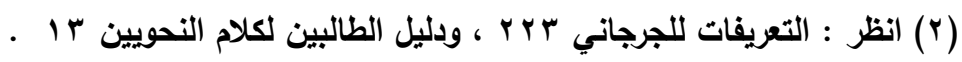

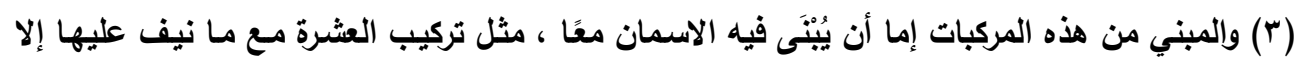

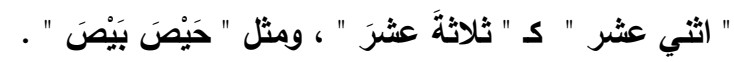

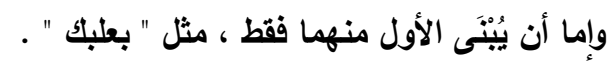

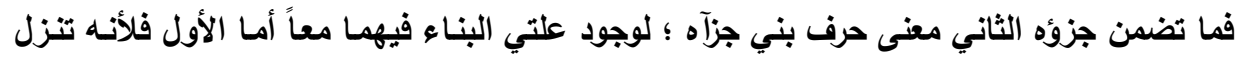

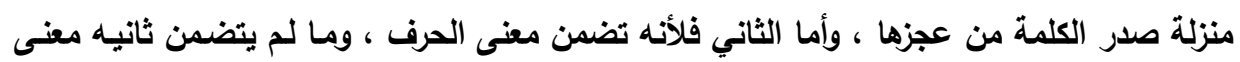

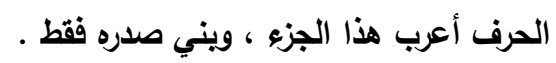

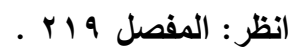

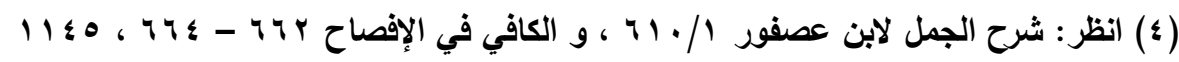

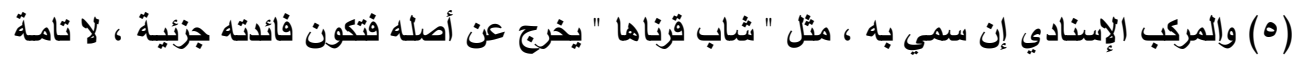

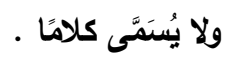

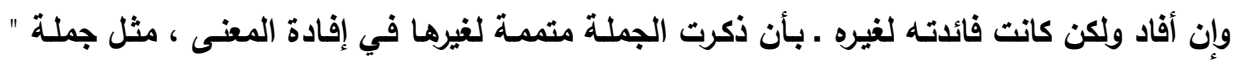

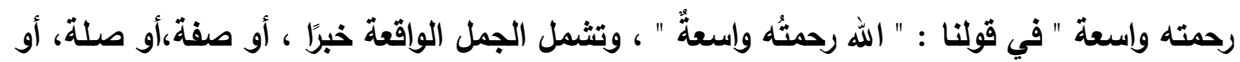

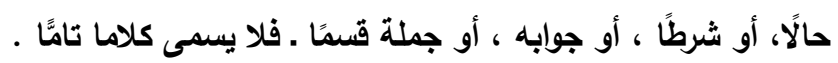

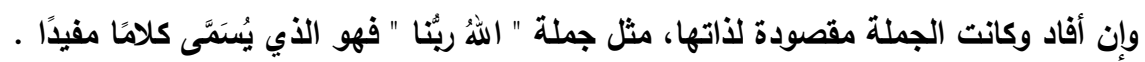


فلا يتأتتى من فعلين ، ولا حرفين ، ولا اسم وحرف ، ولا فعل وحرف ، ولا

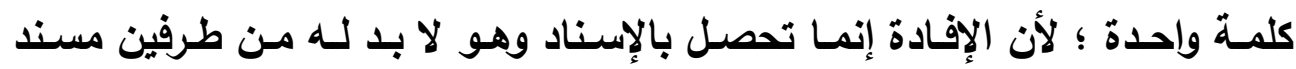

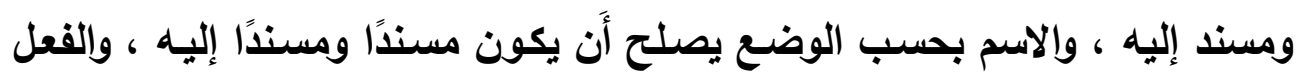

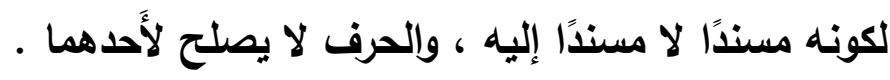

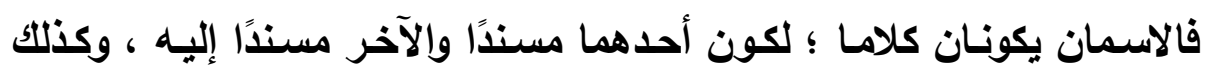

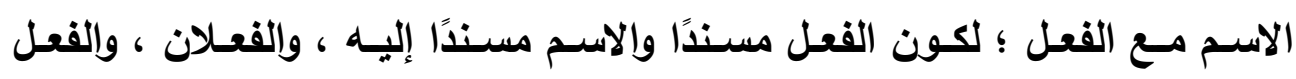

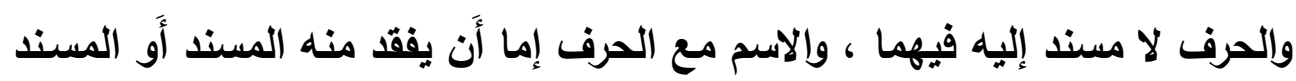

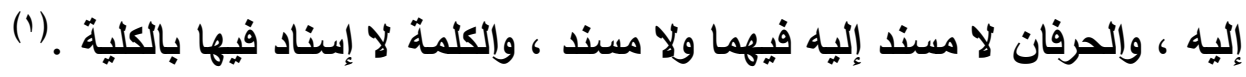
والجملة مختلف فيها :

فذهب الزمخشري إلى أن الكلام يرادف الجملة ، وأفاد ابن هثـام بأن الجملة

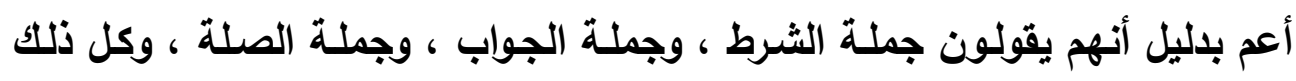
ليس مفيدا فليس كلاما وعلى هذا فحد الجملة القول المركب (؟). بقي أن نقول:إن الإفراد هو الأصل والتركيب خـلاف الأصلـإذ الأصل في

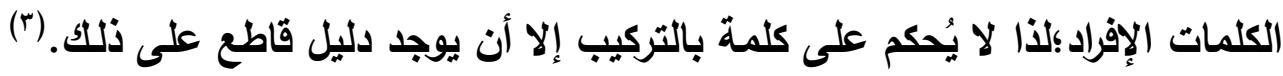

\section{المغرد في باب الإعراب : المراب}

المفرد هنا ما دل على واحد ، أو واحدة ، مثل " كتاب " ، و " ورقة " . ويعرب بالعلامات الأصلية ظ ظاهرة ، أو مقدرة .

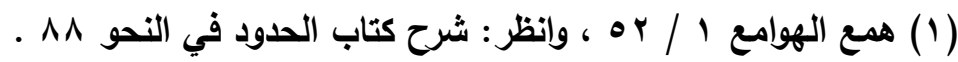

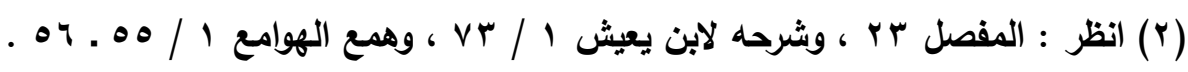

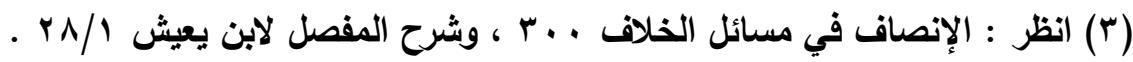




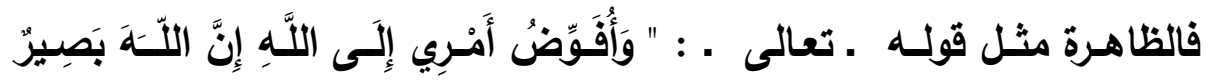

بِالْعِبَِ " (1)

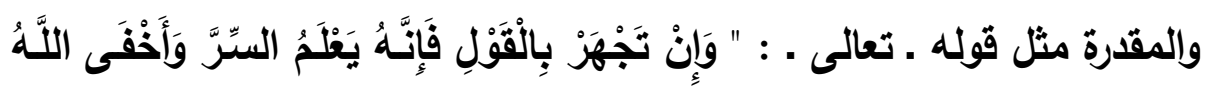

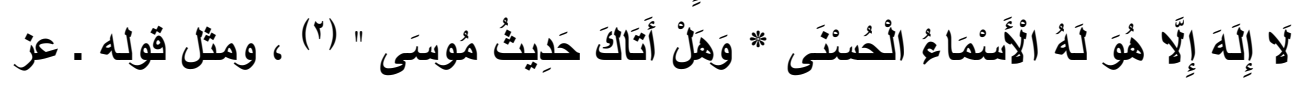

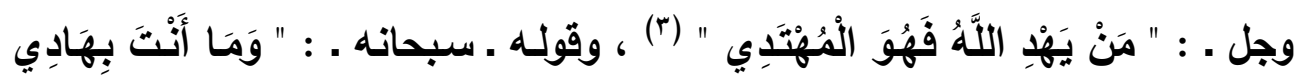

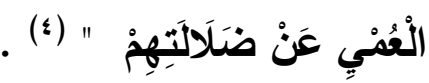

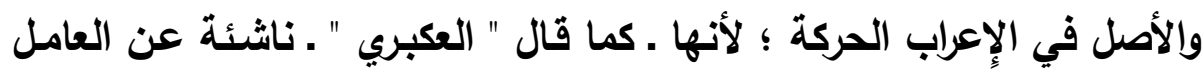

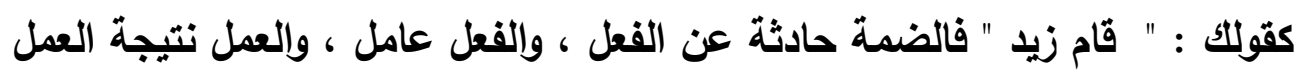

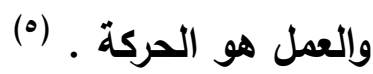

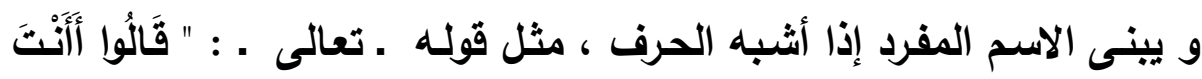

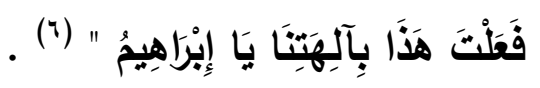

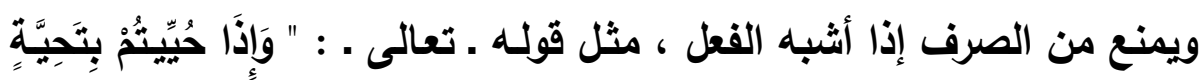

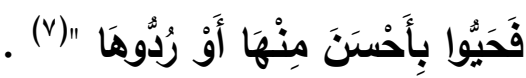

$$
\begin{aligned}
& \text { (1) من الآية (؛ ؛ ) في سورة " غافر ". }
\end{aligned}
$$

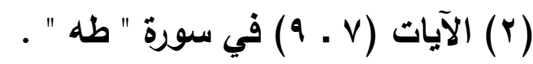

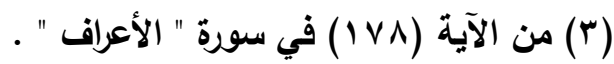

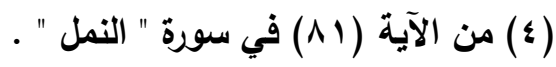

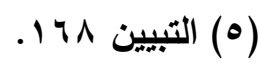

$$
\begin{aligned}
& \text { (T) الآية (ץT) في سورة " الأنبياء ". }
\end{aligned}
$$

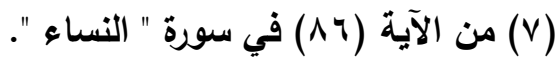




\section{المقابل}

يقابل المفردَ في هذا الباب المثَى، والجمعُ السالمُ بنوعيه ، والجمعُ المكسَّر.

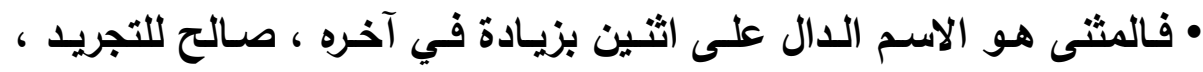

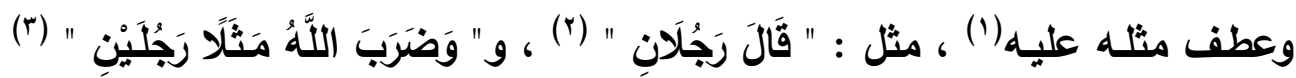

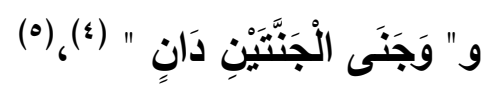
أمـا التثنيـة فعبر عنهـا ابـن مالك بقولـهـ : " جعل الاسـم القابلِ دليـلَ اثتين متفقين في اللفظ غالبًا وفي المعنى على رأي بزيادة ألف في آخره ـ رفًْا ـ وياءٍ

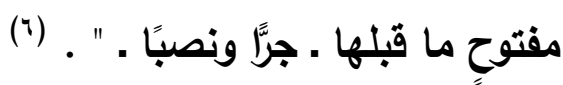
وقـال ابـن الخبـاز : " إنمـا جـيع بها (علامـة التثنيـة ) في الكـلام للإيجـاز والاختصار؛ لأن قولك : " زيدان " يغتي عن " زيد وزيد " ل

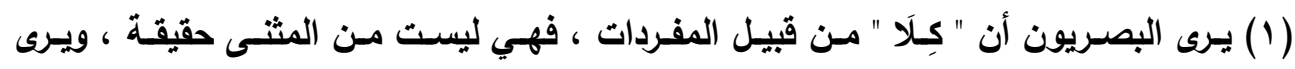

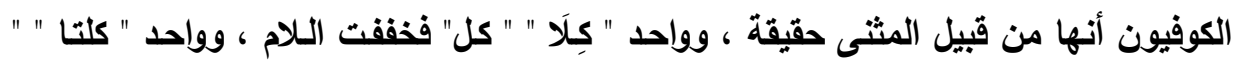
كِلت " ، وأنثدوا :

في كلت رجليها سلامى واحده كلتاهما مقرونـة بزائده

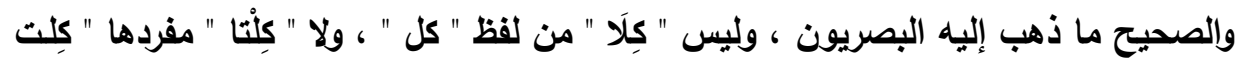

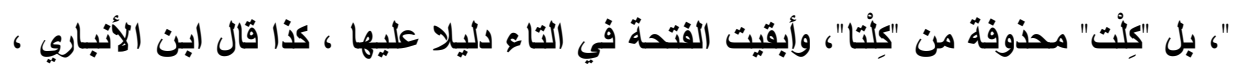

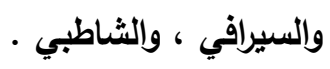

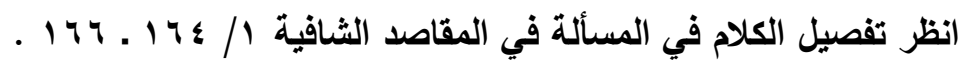

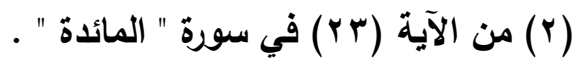

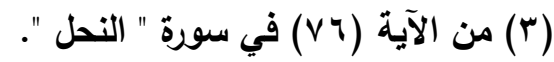

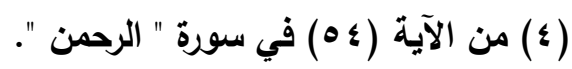

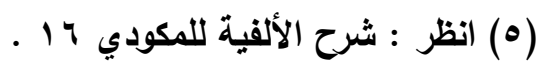

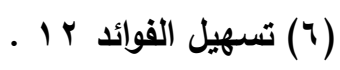

$$
\begin{aligned}
& \text {. . توجيه اللمع (V) }
\end{aligned}
$$


والألف والياء في المثنى علامتا إعراب عند الجمهور • وقال الأخفش والمازني والمبرد : إنهما دليل الإعراب ، فوجود الألف دليل على الرفع ، ووجود الياء دليل على النصب أو الجر ، والإعراب مقدر عليهما كما يقدر

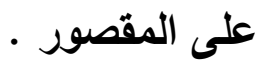

وقال الجرمئٌ : الألفُ حرفُ إعراب ، وانقلابُها هو الإعراب . (1) وحُكِيَ عن " الزجاج " أن المثنى ـ ومثثله جمع السـالم ـ يتضمنان معنى واو العطف فكان الاسم به مبنيًّا ك " خمسة عشر " ونحوه . والصـواب أنهمـا غير مـركبين ؛ لأن التركيب يبقى معسه لفظ كل واحد مـن

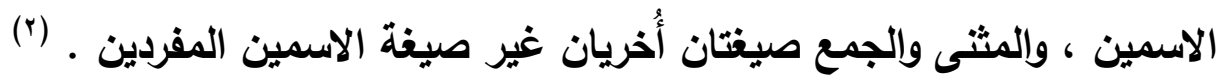
• والجمع هو ما دل على أكثر من اثثين أو اثتثين ، فإن سلم فيه بناء المفرد فهو السالم ، وإن تغير فهو المكسَّر ، ثم إن السالم إن دل على أكثر من اثثين فهو جمع المذكر ، وإن دل على أكثر من اثنتين فهو جمع المؤنث .

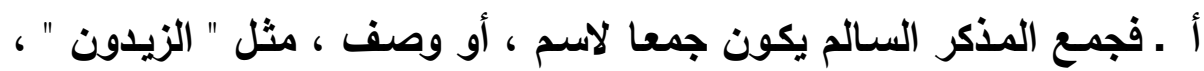

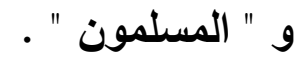
ويشترط فيما يجمع هذا الجمع أن يكون مذكرا عاقلا خاليًا من تاء التأنيث. (r)

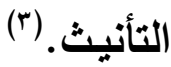

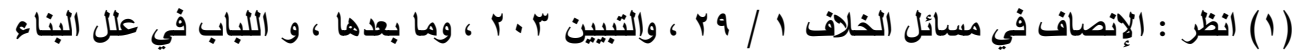

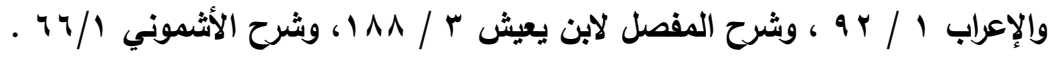

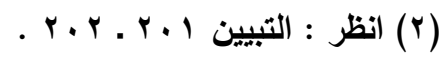

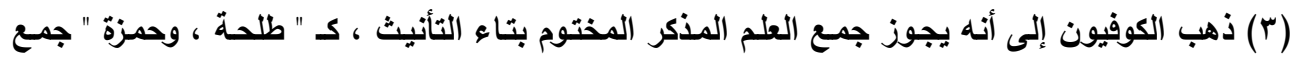

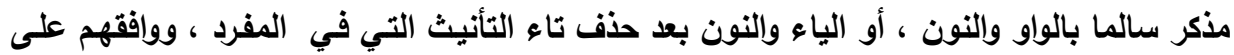

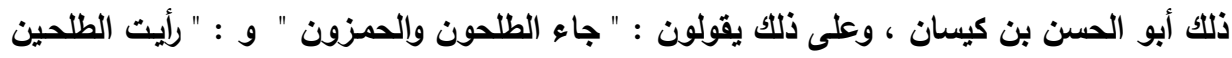


فإن كان علمـا (') زِيدَ على ذلك أن يكون خاليا من التركيب(†) ، وإن كان

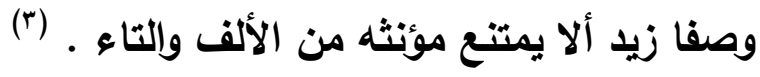

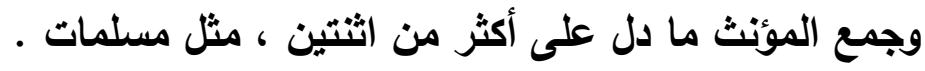

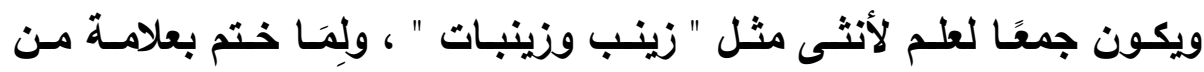

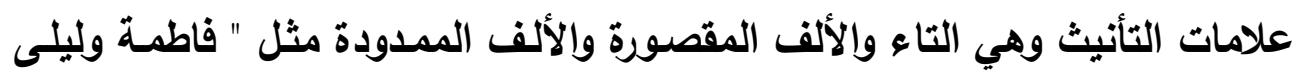
وحسناء " فتجمع على " فاطمات وليليات وحسناوات " .

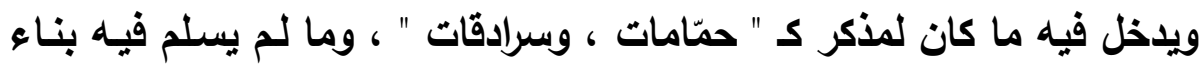

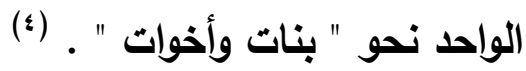

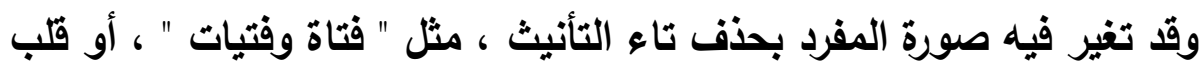

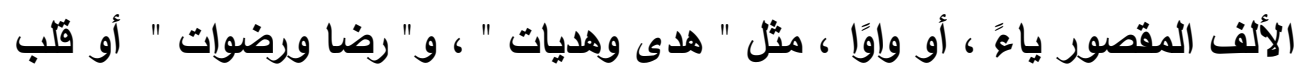

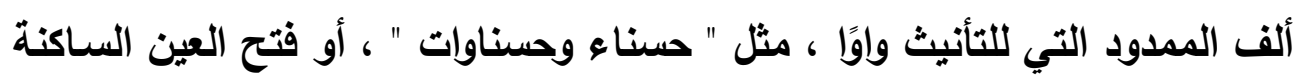

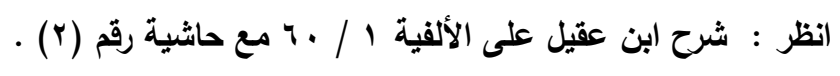

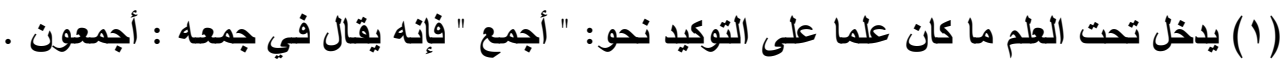

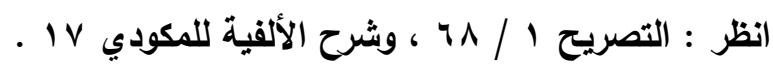

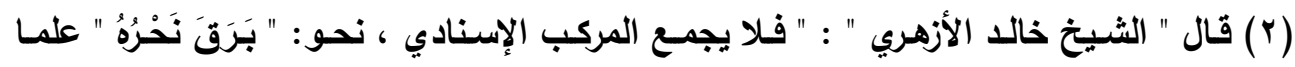

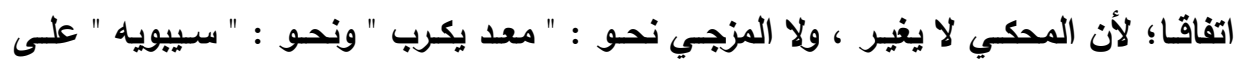

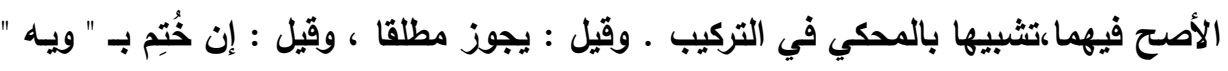

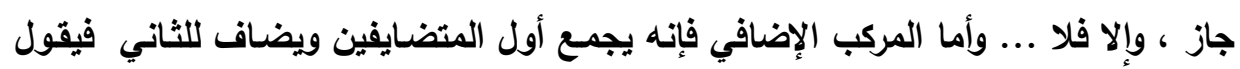

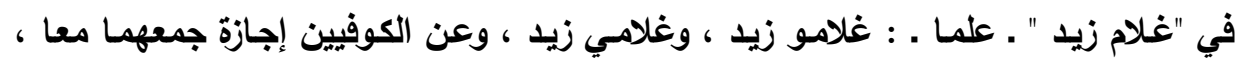

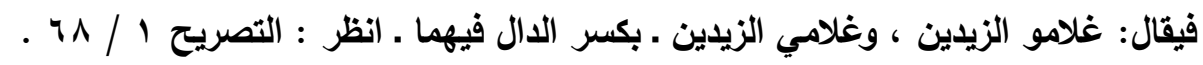

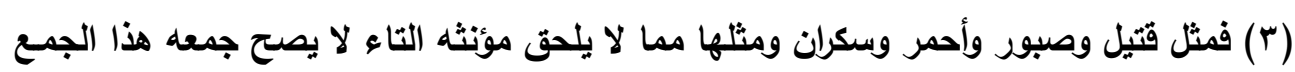

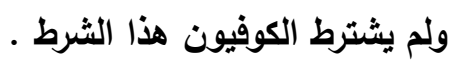

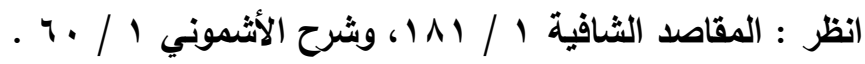

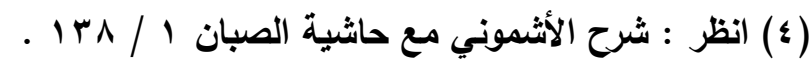


في الأسماء التي على وزن " فُعل " ، أو " فُعْلة " ، مثثل " سجْدة وسجَدات " (1) ، وتنوب الكسرة عن القتحة فيه في حالة النصب حملًا على جمع المذكر السالم لأنسه فرعه ، فحملوا النصب على الجر ليلتحق الفرع بالأصل ، كما جعلوا التنوين هنا في

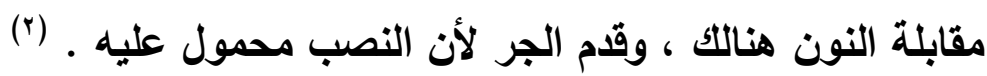

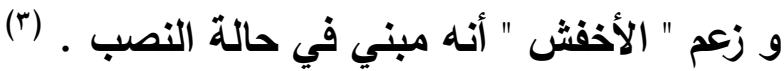

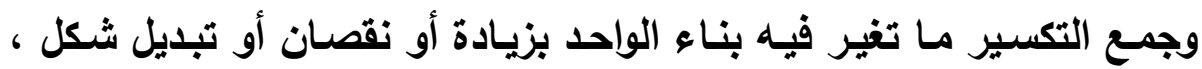

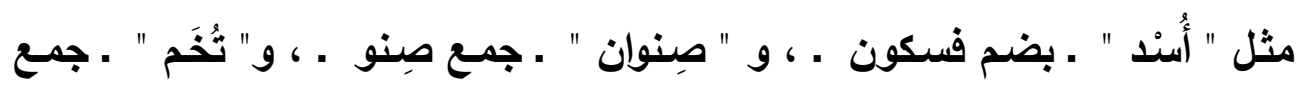

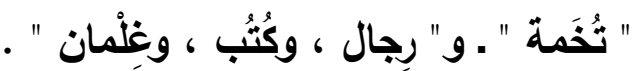

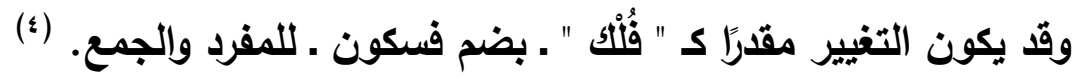

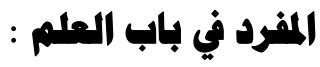

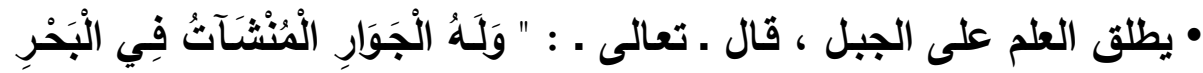

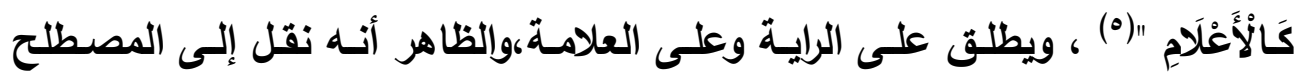

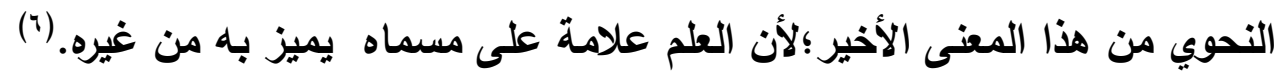

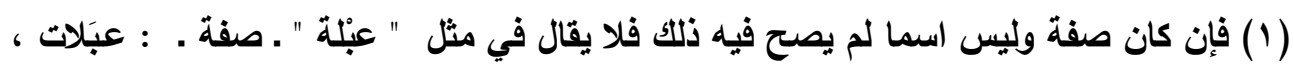

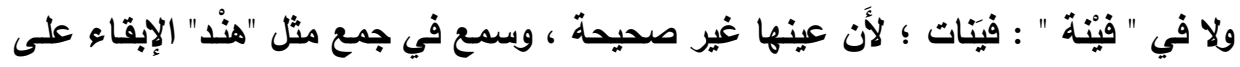

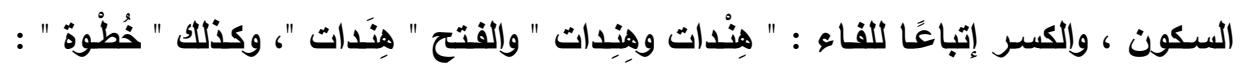

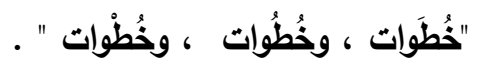

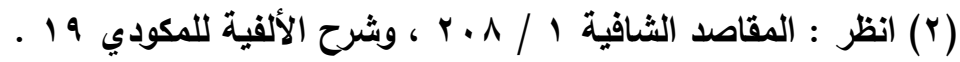

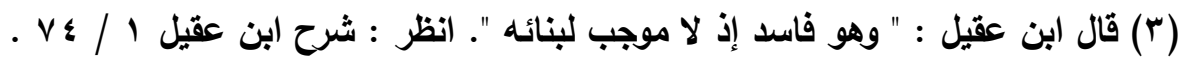

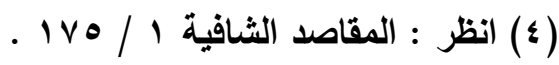

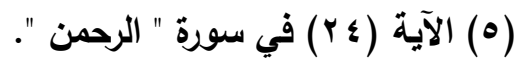

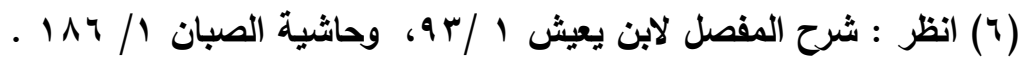


أما عند النحويين فهو الاسم الأي علق في أول أحواله على شـيء بعينه في

جميع أحواله من غيبة وخطاب وتكلم . (1)

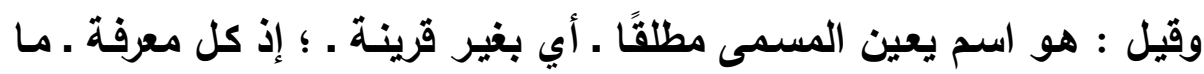

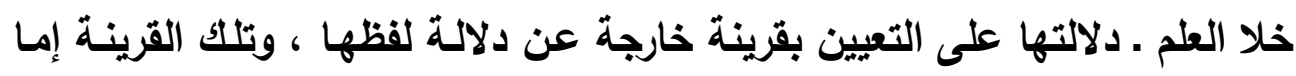

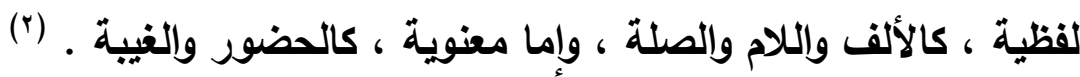
• والمفرد في هذا الباب هو مـا عيَّن مسماه وتَكَّون من كلمـة واحدة ، مثل "

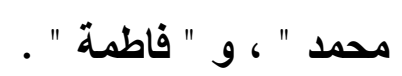

والمراد بالإفراد أنه يدل على حقيقة واحدة قبل النقل ويعده .

والعلم المفرد هو الأصل ؛ لأَن التركيب بعد الإفراد، وذلك نحو " خالا وعمرو". والعلم المفرد يأخذ حكمه الإعرابي ، رفعا أو نصبا أو جرا ، بعلامـات ظاهرة أو الو مقدرة حسب موقعه في الجملة ، وصحة آخره أو علته ، وإذا وجدت فيه علة مانعة اونة من الصرف منع من من من من

\section{الإقابل}

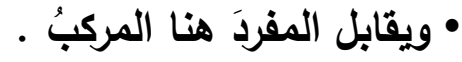

وهو الأي يالّ على حقيقة واحدة بعد النقل ، وقبل النقل كان يدلّ على أكثر

من ذلك . منو (r)

أ ـ فبإن تركب من مضـاف ومضـاف إليه ، مثل " عبدالله " ، و " أبويكر " ،

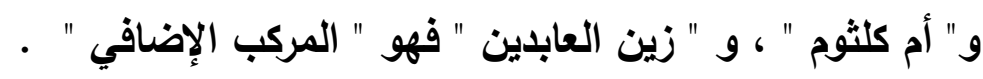

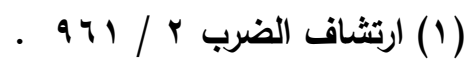

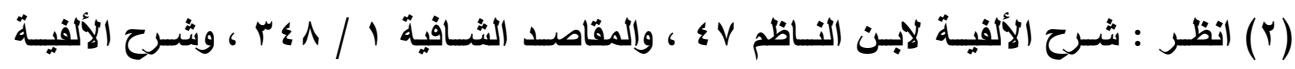

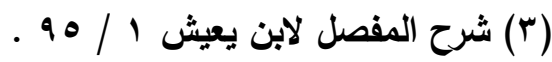


وحكمه أن يعرب صدره حسب موقعه في الجملة،ويلزم آخره الجر بالإضافة . ب وإن تركب من جملـة تكونت في الأصل من مبتدأ وخبر (1) ، أو فعل وفاعل أو نائبه،مثل " النصر قادم " ، و " برق نحره " فهو " المركب الإسنادي". ويسميه بعضهم " المركَّب الجُمْلِيّ " (؟) . وحكمه أن يبقى على صورته قبل التسمية على سبيل الحكاية ، وتقدر عليه علامات الإعراب . ماب

ج - وإن تركب من كلمتين امتزجتا ـ أي: اختلطتا ـ ، فهو المركب المزجي . وركبت الكلمتان هنـا ـ لا على جهة الإضـافة ، ولا الإسناد - حتى صسارتا

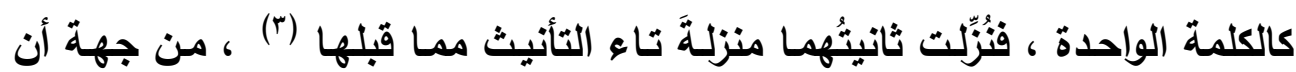
الإعراب والبنـاء يكون على آخرهـا ، أمسا آخر الأولى فيلزم حالة واحدة ، مثل: "

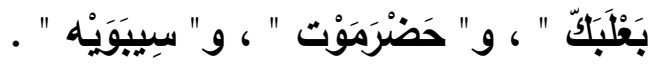

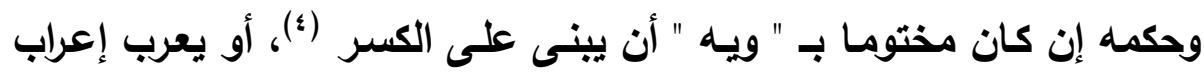
الممنوع من الصرف ـ على خلاف في ذلك . .

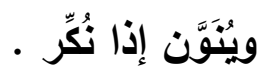

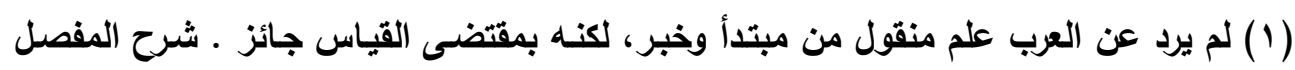

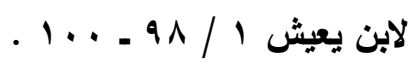

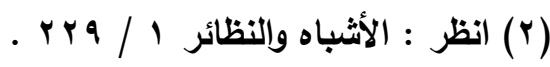

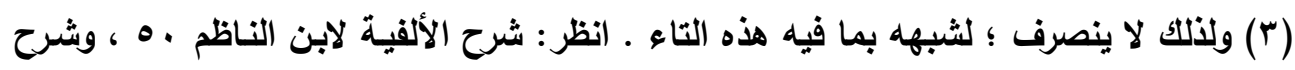

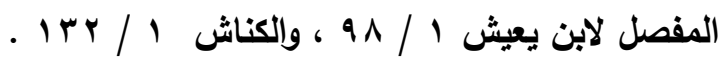

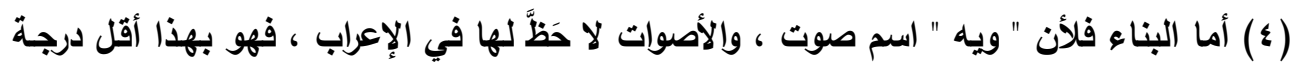

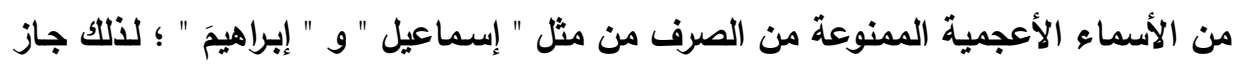

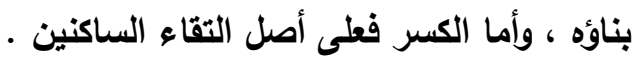

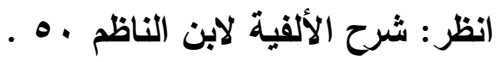


وإن لم يكن مختوما بها فيأخذ حكم الممنوع من الصرف ، ويفتح جزؤه الأول

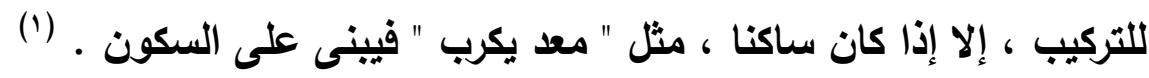

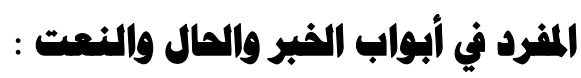

المفرد في هذه الأبواب مـا ليس جملة ، ولا شبهرها ، مثنى كان أو مجموعا

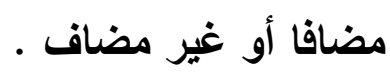

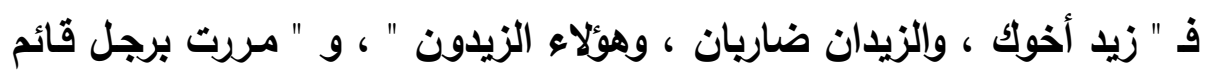

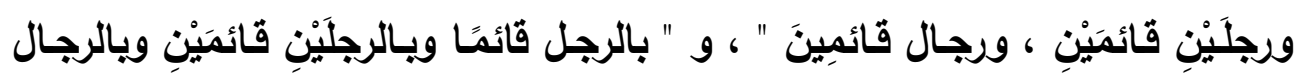

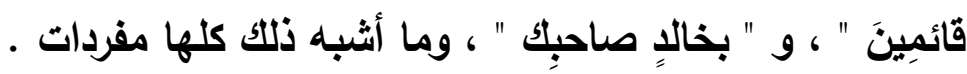

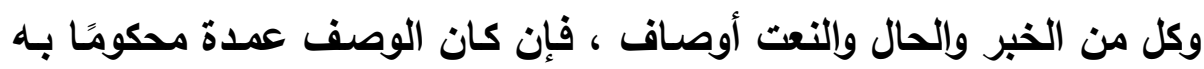

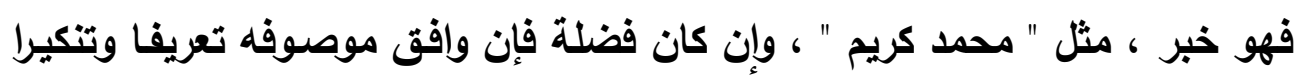

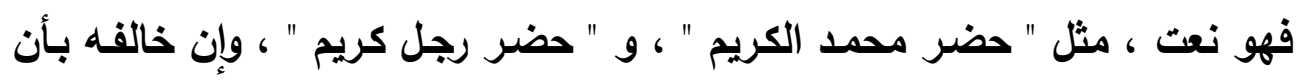
جاء نكرة وموصوفه معرفة فهو حال ، مثل " حضر محمد كريمًا " .

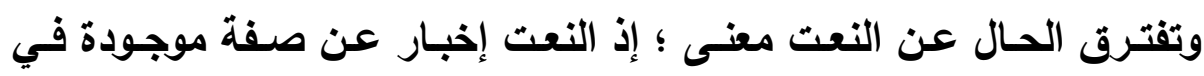

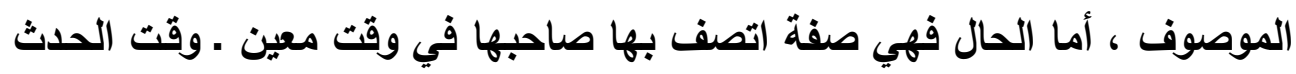

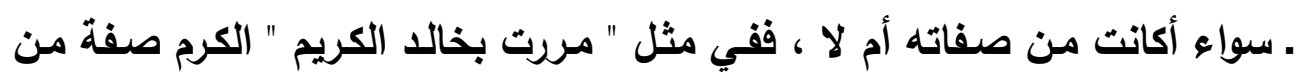

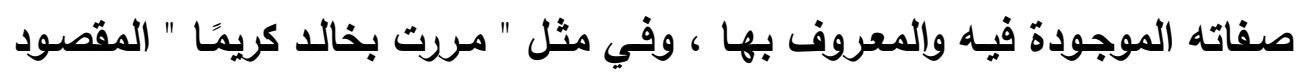

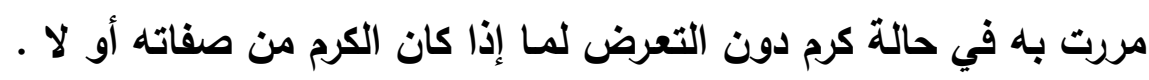

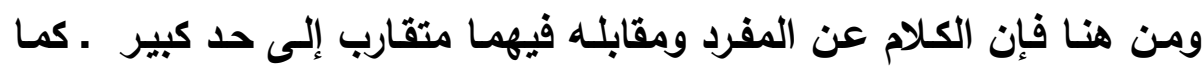
سيأتي . - n

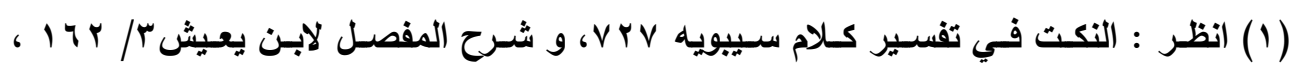

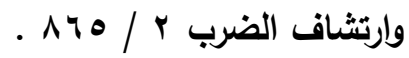


أولَا : الخبر :

هو الجزء من الجملة الاسمية الذي تحصل به الفائدة التامة مع مبتدئه ( ).

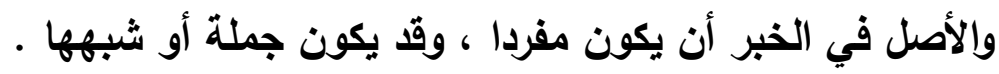

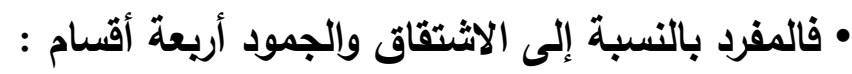

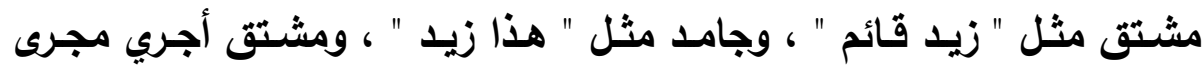

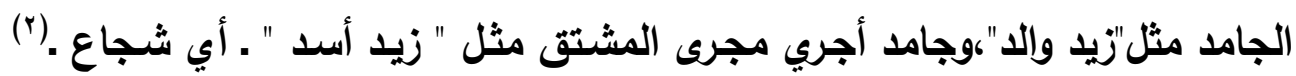

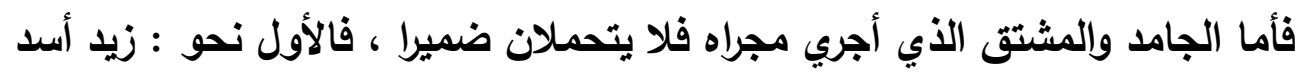

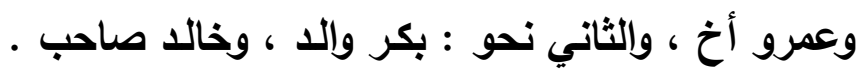

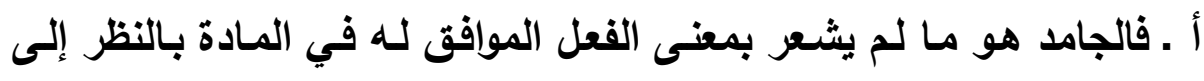

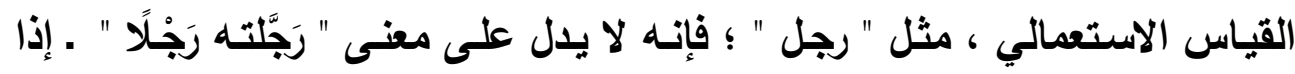

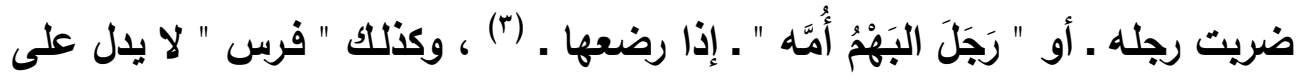

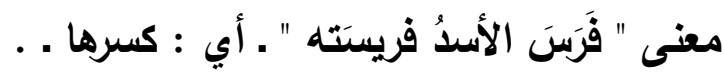

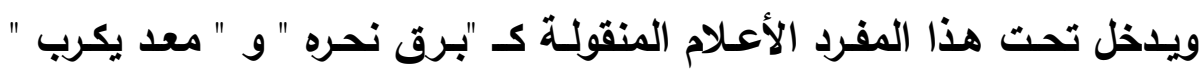
وغيرهما ، فإنها بهذا الإطلاق مفردات لا جمل ، وكذلك الموصولات مفردات أيضًا؛

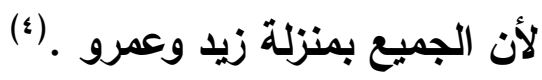

(1) قد تكون الفائدة بهه مثل " الله رينا " ، أو بمتعلقه كما في صورة الإخبار بالظرف والجار

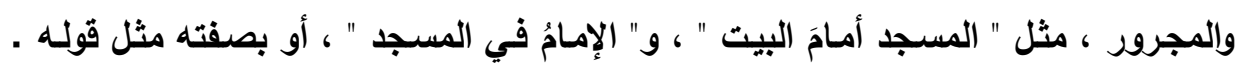

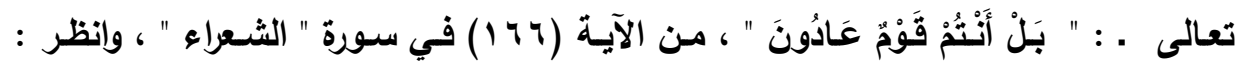

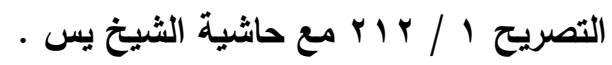

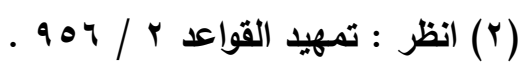

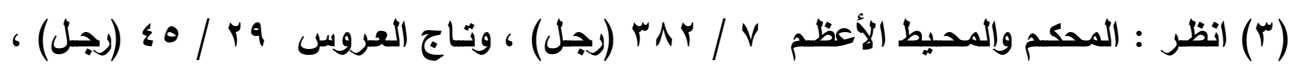

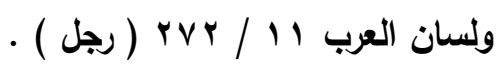

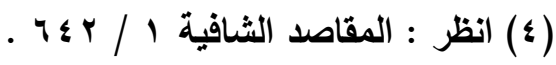




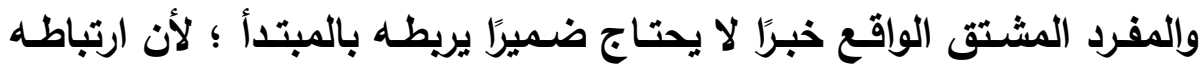

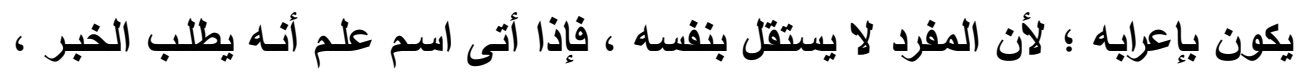
وإذا جاء بعده اسم مرفوع علم أنه خبره .

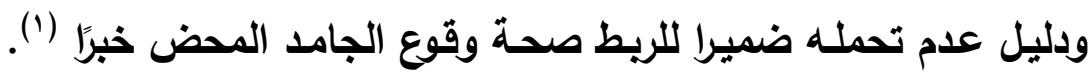

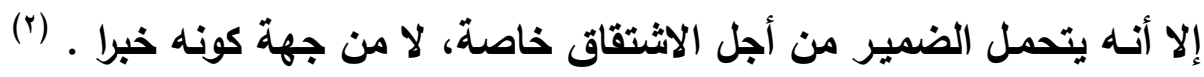
وقد يجري المفرد الجامد الواقع خبرًا مجرى المشتق فيتحمل الضمير ، مثل .

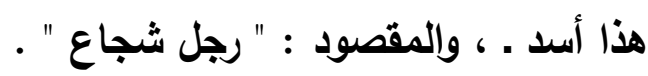

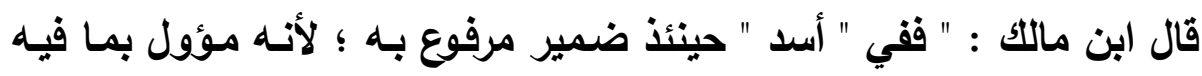

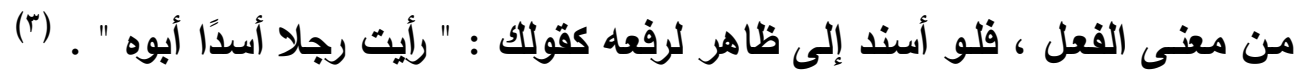

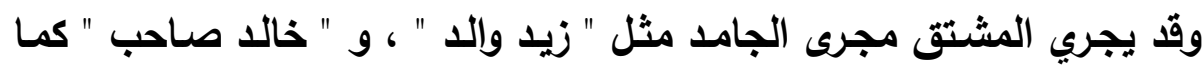

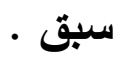
ب ـ وأما المشتق فهو الذي يشعر بمعنى الفعل الموافق لـه في المـادة بالنظر

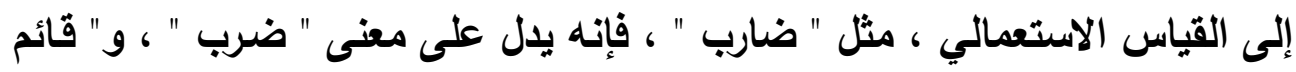

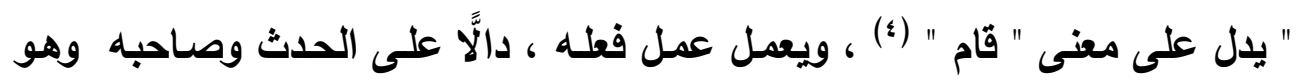

(1) وذهب الكوفيون ، وعلي بن عيسى الرماني من البصريين إلى أنّ خبر المبتدأ إذا كان اسمًا

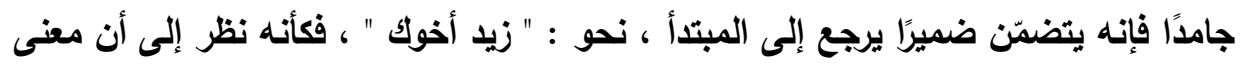

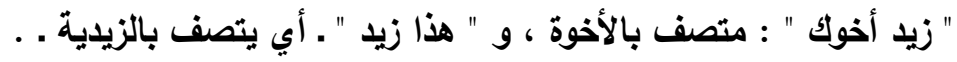

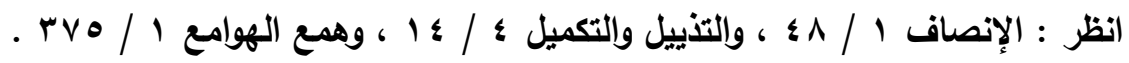

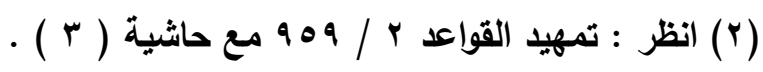

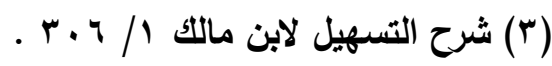

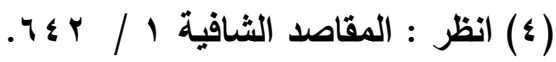


اسم الفاعل ، واسم المفعول ، وما هو بمعناه ، كفعيل بمعنى مفعول ـ في مثل أمين

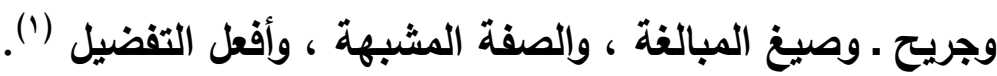

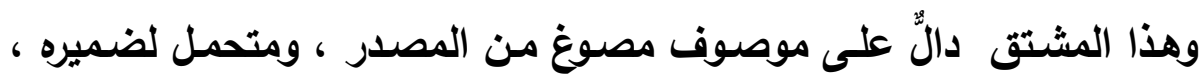

ك " ضارب ، ومضروب ، وحسن ، وأحسن منه " .

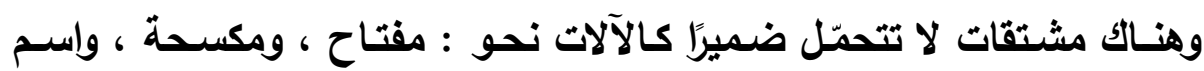

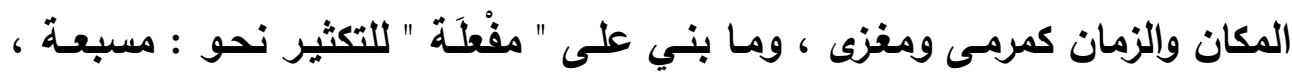

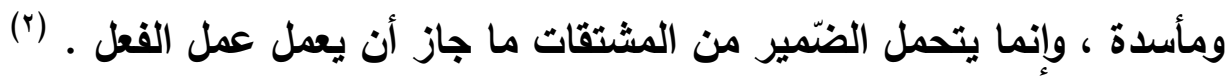

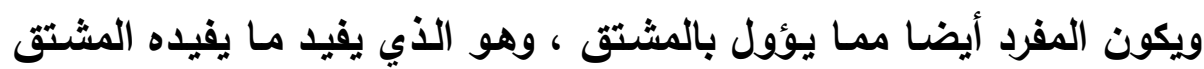

من المعنى ، وهو المسمى بالمشتق تأويلا ، كاسم الإثارة ، و" ذو " بمعنى صساحب

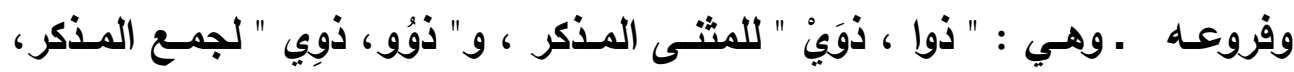
و" ذات " للمفـردة المؤنثـة ، و" ذاتـا ، وذاتَـي " للمثنى المؤنـث ، و" ذوات " لجمـع المؤنت و" ذو " الموصولة وفروعها ، وكذلك الموصولات الاسمية المبدوعة بـ " ال "

ك"الأي والتي"و"ال" نفسها،والاسم المنسوب كـ " دمشقي ، وأسماء الأعداد . (r)

\section{إلمابل}

• كما سبق فالمفرد هنا يقابله الجملة ، وشبهها .

فالجملة قد تكون اسمية ، مثل " الجنة أبوابها ثمانية " ، أو فعلية ، مثل :

" لشَّبَّطَانُ يَعِدُكُمُ الْفَقْرَ " (؛) ، وهذه الجملة تكون مؤولة بالمفرد ، وهي إما أن تكون بمعنى المبتدأ ، أو تخالفهه ، فِإن كانت بمعنى المبتدأ فـلا تحتاج إلى رابط ، وذلك

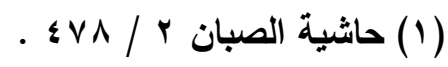

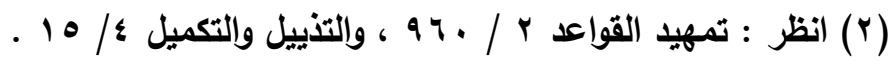

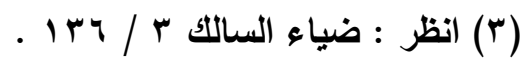

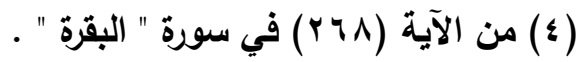


بأن تكون جملة الخبر تلدّ على المعنى نفسـه الذي يدل عليه المبتدأ ، نحو : "

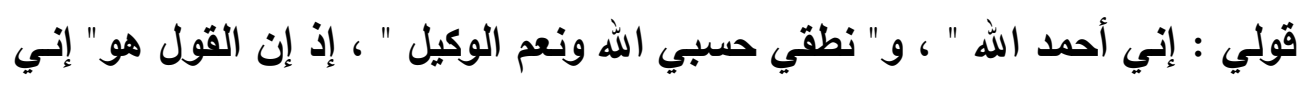
أحمد الله " ، و النطق هو " حسبي الله ونعم الوكيل " ، فدلت جملـة الخبر في لهي

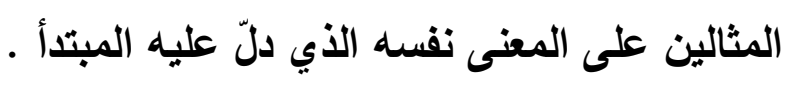
وإن لم تكن بمعنى المبتدأ فلابد من وجود رابط يريط بين جملة الخبر والمبتدأ

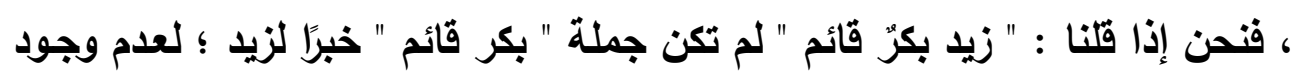

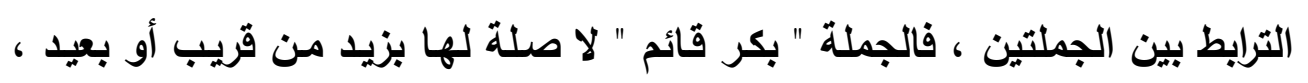

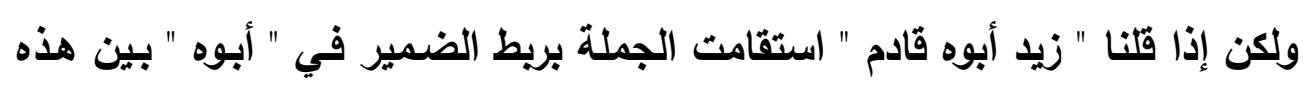
(الجملة وإلمبتدأ . الجنأ ومذهب الجمهور أن الجملة في هذا الباب تكون خبرية و طلبية ، ولا يثترط فيها أن تكون محتملة للصدق والكذب .

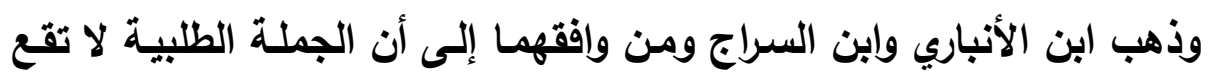

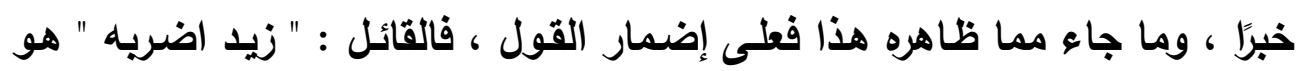

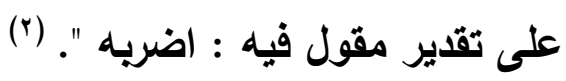

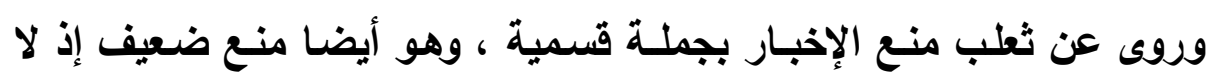

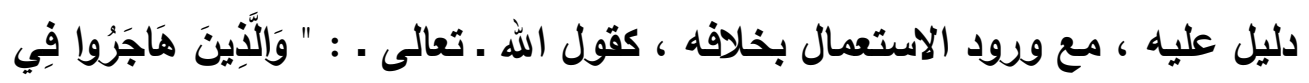

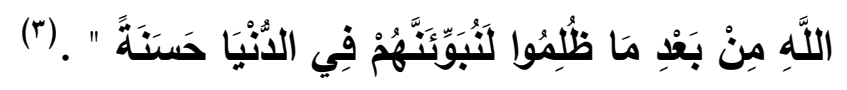

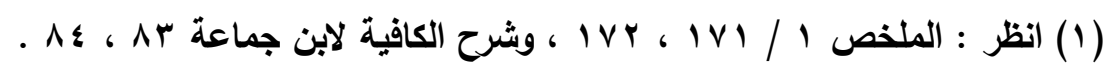

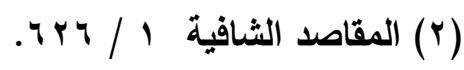

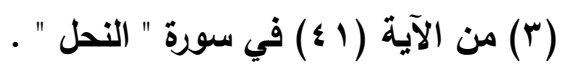




\section{ويتعين الإخبار بالجملة إن كان المبتدأ واحدًا مما يأتي :}

أ- أسماء الشرط الواقعة مبتدأ وخبرها جملة الشرط وجوابه ، مثنل " مَنْ يَعْمَلْ

\section{سُوعًا يُجْزَ بِهِ " (1)}

ب- المخصوص بالمدح أو الأم إن كان مقدّما مثل " الصدق نعم المنطق " .

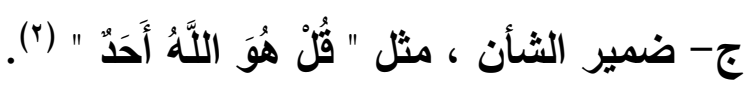

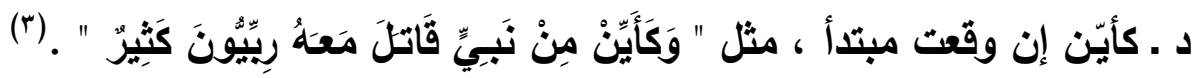

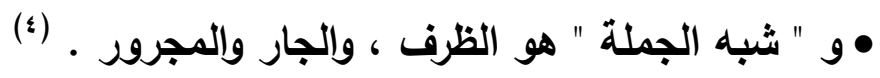

• وأطلق عليهمـا " شبه جملـة " ؛ لأنهمـا ينويـان عن الجملـة وينتقل إليهمـا ضمير متعلقيهما نحو "زيد في البيت ، أو عندك " ، فبإن المعنى زيد استقر أو مستقز ، أو كان أو كائن .

وكذلك فإنهمـا سـواء كانـا تـامين أو غير تـامين لا يؤديـان معنى مستقلا في الكلام وإنما يؤديان معنى فرعيًّا فكأنهما جملة ناقصة ، أو شبه جملة .

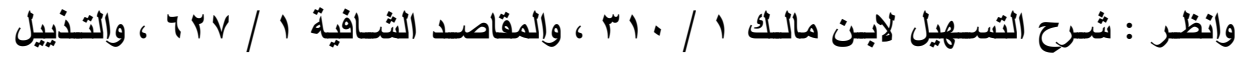

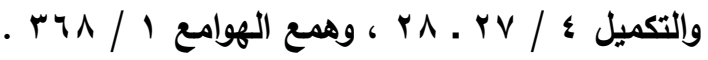

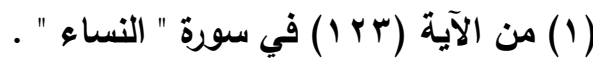

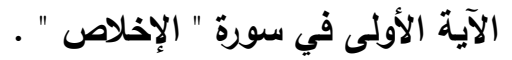

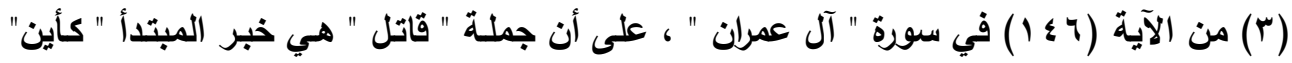

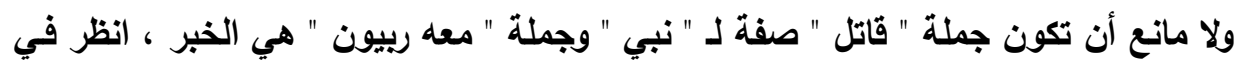

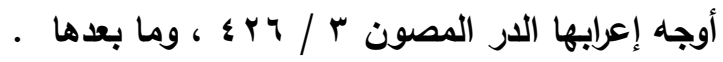

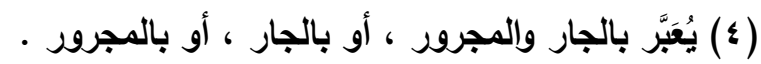


ولابدّ لثبه الجملة من متعلق تتعلّق بـه ، والتعلق يعني ارتباط شبه الجملة

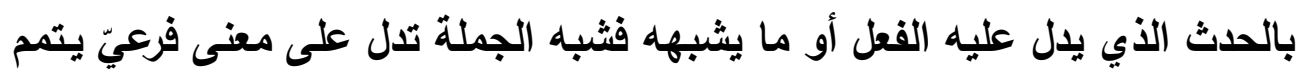

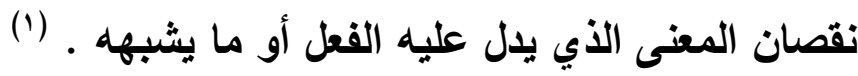

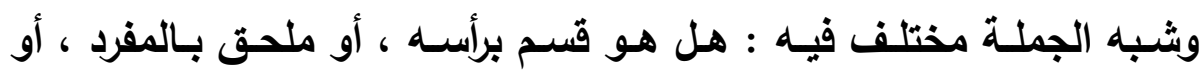
الجملة :

فيرى المحقّقون كابن السـراج والفارسيّ والثـلوبين وغيرهم أن الظرف ، أو الجار والمجرور قسم قائم برأسه بين المفرد والجملة ، فهو ليس من قبيل فيل المفرد

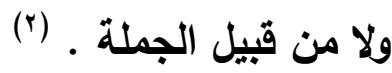

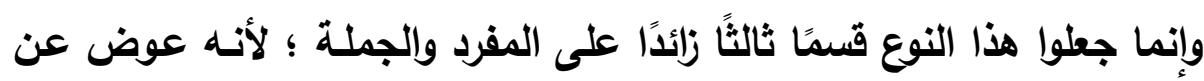

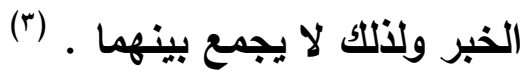

وقالوا : إن وجوب تعلق الظرف والجار والمجرور بمقدر والمقدر كالظاهر لا

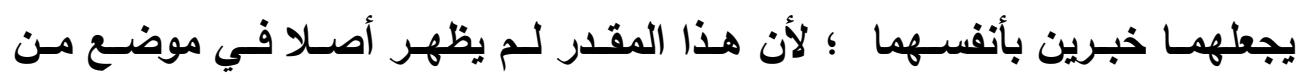

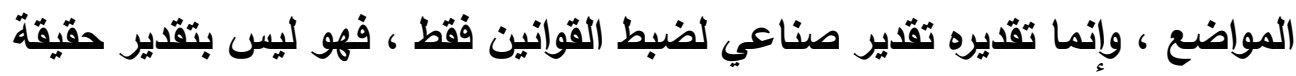

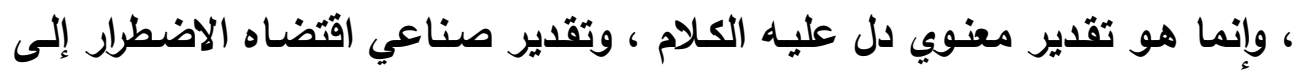

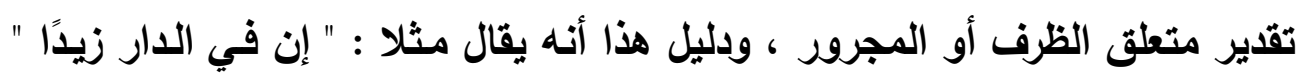

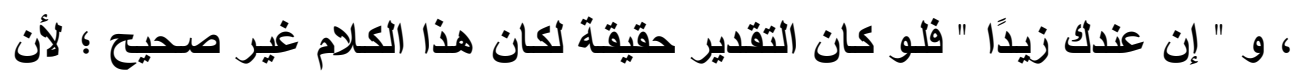

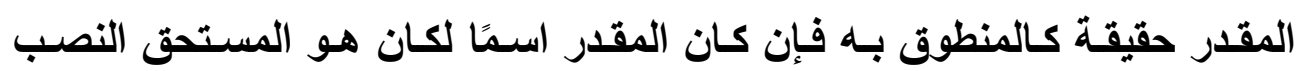

(1) انظر : التطبيق النحوي Vor rov.

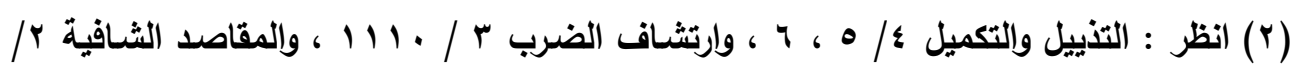
. qor

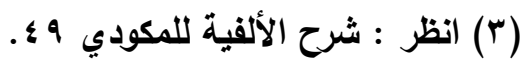


ولارتفع " زيد " في المثالين ، وإن كان المقدر فعلًا فالفعل لا يصح أن يلي " إنّ " .

وقيل : بل هو ملحق بالمفرد ، أو الجملة حسب التقدير ؛ فإنسه لابد للجار

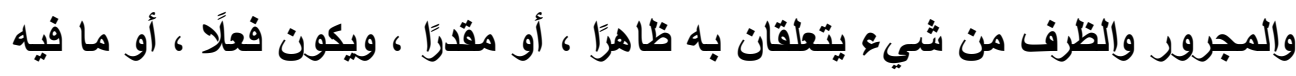

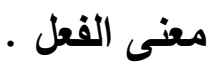
قال المكودي : " واختار ابن مالكك ـ يغني في نظمه للألفية ـ تقديره بالمفرد ولذلك قدمه ، ووجهه أن أصل الخبر الإفراد وإختار أكثر البصريين تقديره بالفي مالفعل

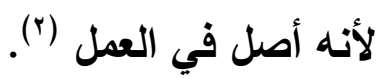
والمتفق عليه أن الجار والمجرور والظرف يتعلقان بمحذوف هو عند أكثرهم

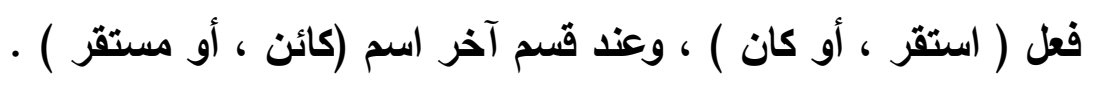

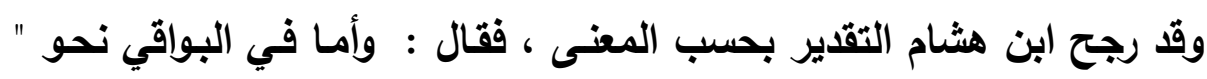

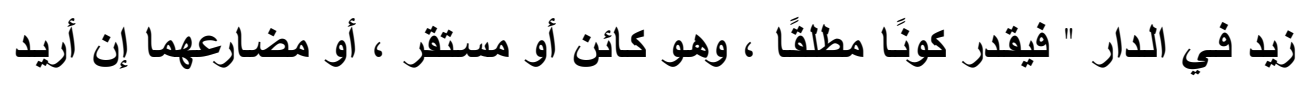

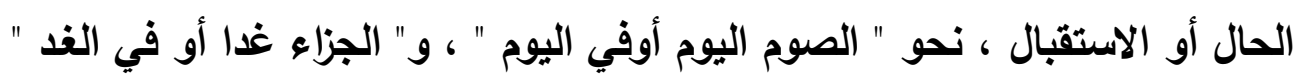

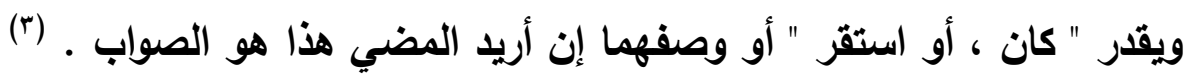

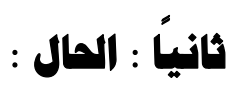

• والمفرد هنا يشمل الحال عندما تكون اسمًا مشتقًا وعندما تكون مصدرًا ،

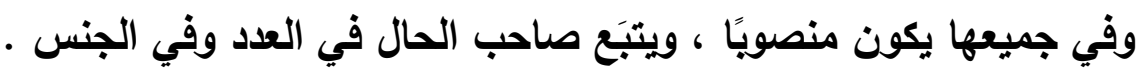

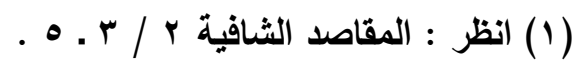

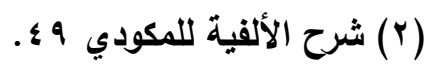

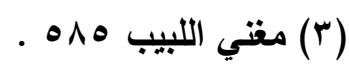




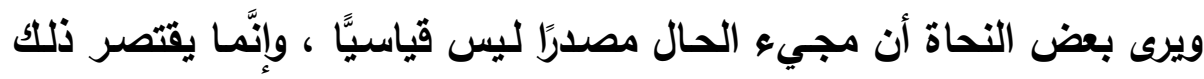

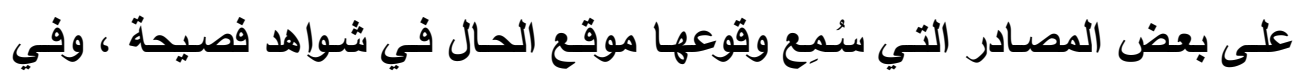

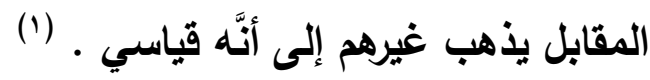

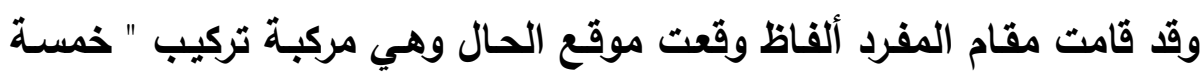

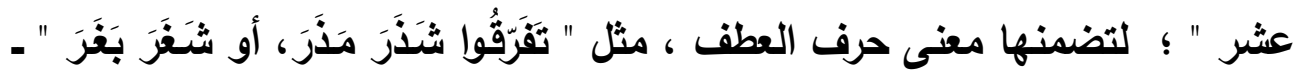

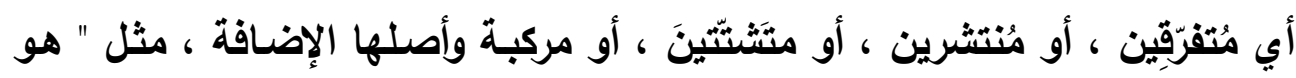

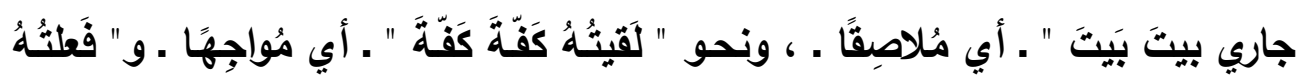

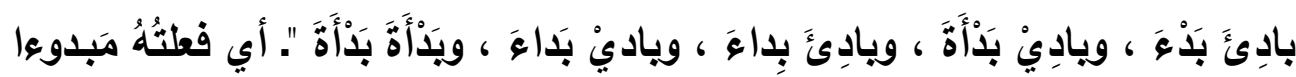

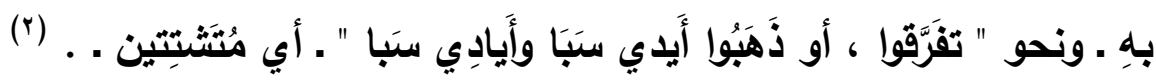

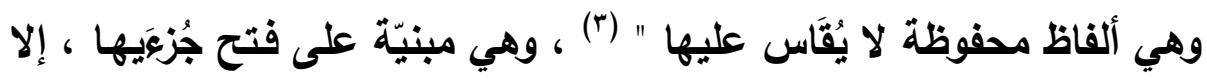

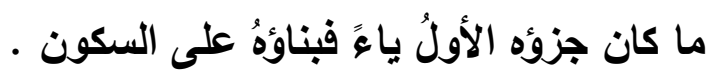

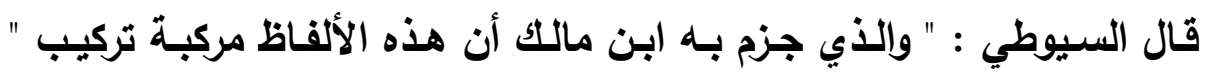

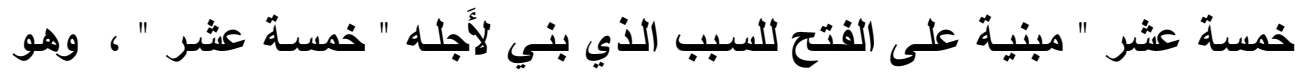

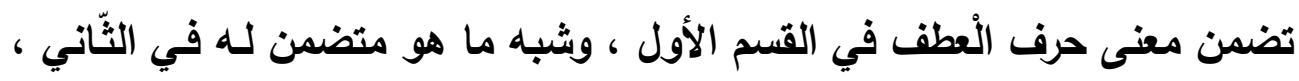

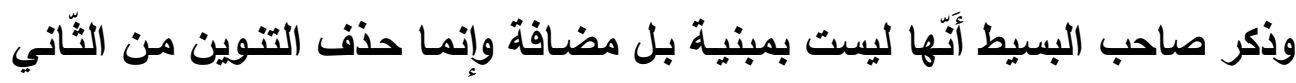
للإتباع وحركة الإتباع ليست حركة إعراب فهو مخفوض في التقدير كما أتبع الأول

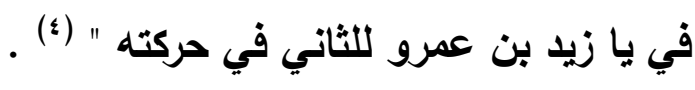
الإقابل

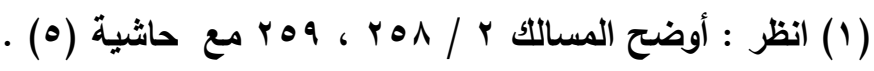

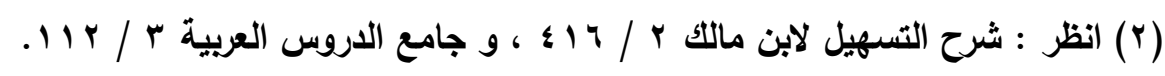

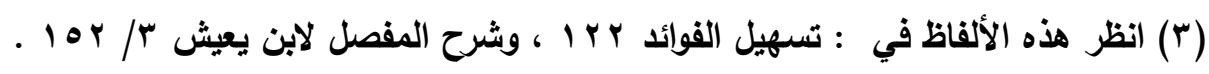

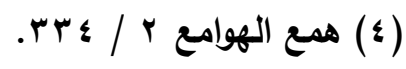


• كما سبق فالمفرد هنا يقابله الجملة ، وبثبهها .

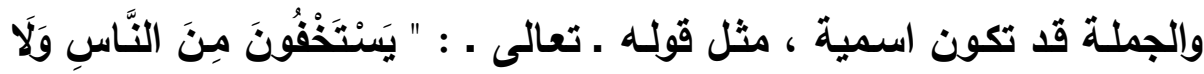

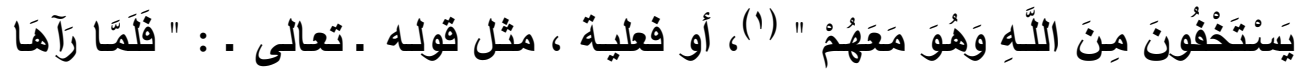

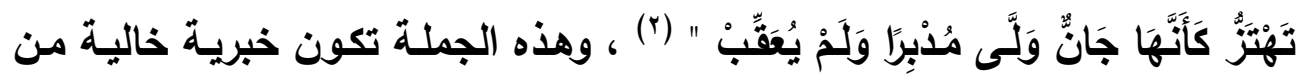

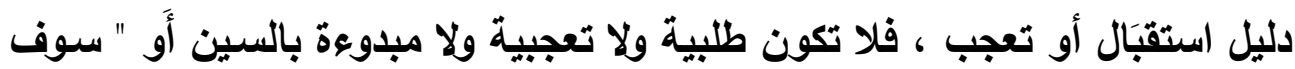

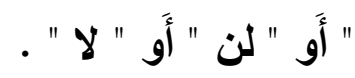
قـال السـيوطي : " وجـوز الفـراء وقـوع جملـة الأَمـر تمسكا بنحو : " وجدت

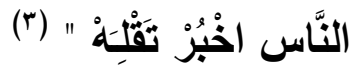
وأجيب بأَنه على تقدير : " مقولا فيهم " . وجوز الأمين المحلي وقوع جملة النهي نحو :

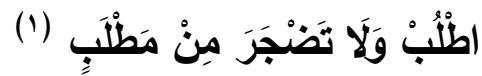

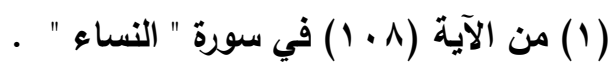

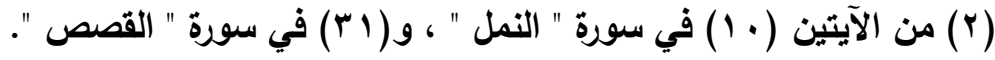

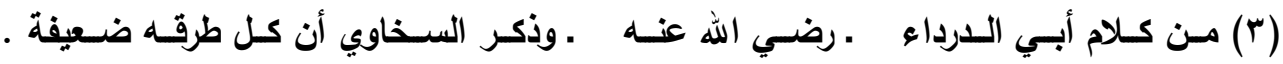

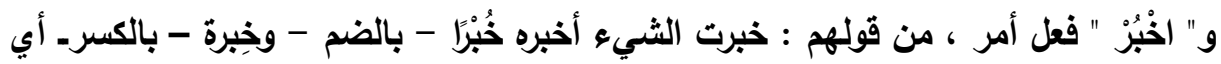

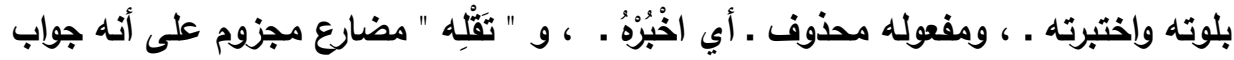

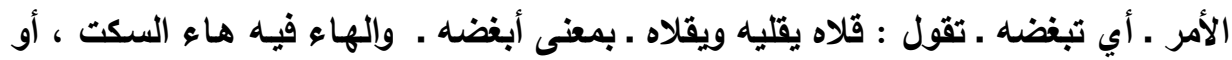

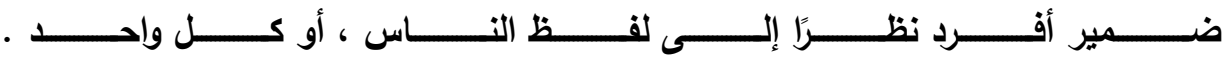

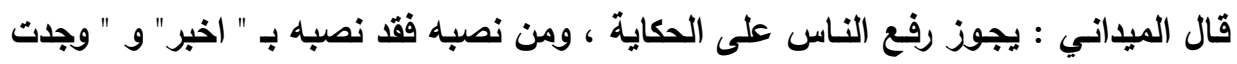

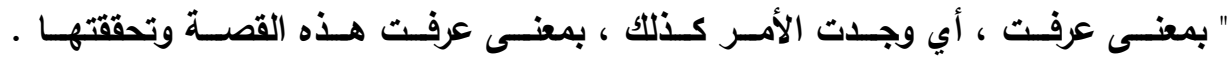

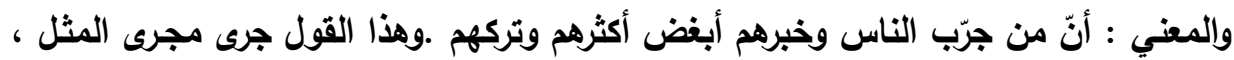

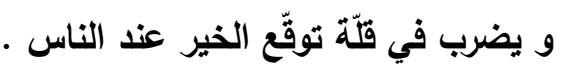

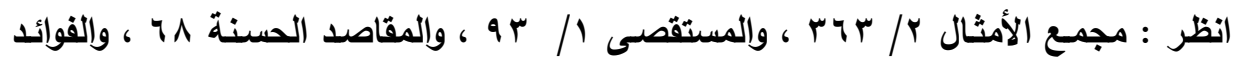

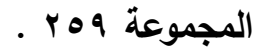


ورد بأن الواو عاطفة ـ (ץ)

وإذا جاعت الحال جملة فقد تحتاج إلى رابط ، وهو إمـا الضمير والـواو معًا

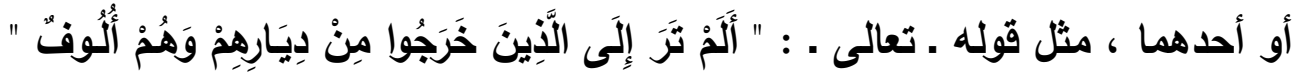

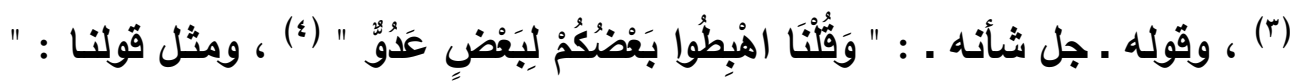

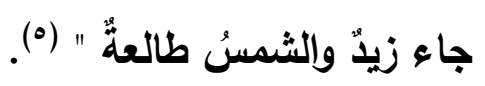

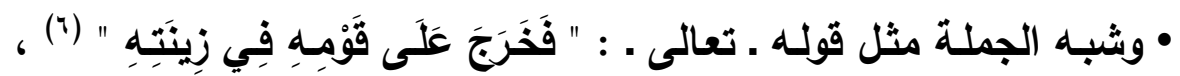
وقولهم : " أيث الههلال بين السحاب "

ويشترط فيما يقع حالا من الجار والمجرور أو الظرف أن يكون تاما . والقول في شبه الجملة هنا هو القول في شبه الجملة في باب الخبر •

ثالثا : النعت. (v) وأيضًا يقابل المفردَ في هذا الباب الجملةُ ، وشبهُها .

(1) صدر بيت من السريع ، ولم اهتد على قائله .

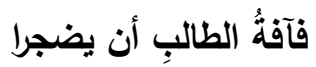
عجزه :

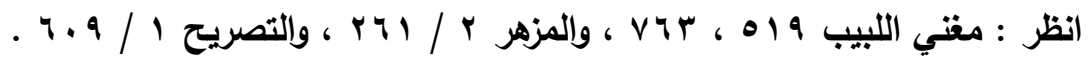

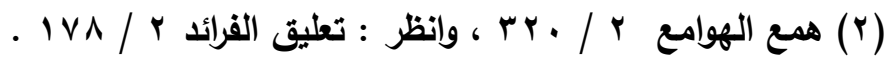

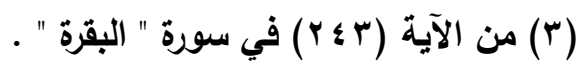

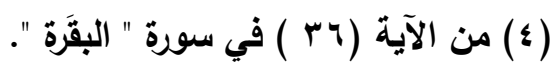

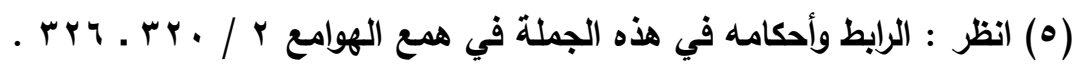

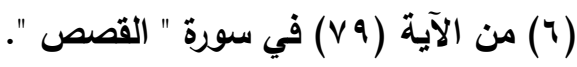

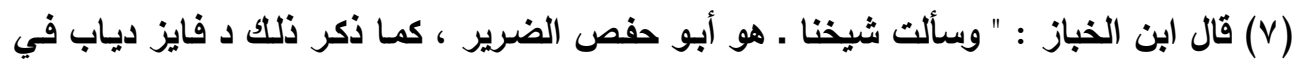

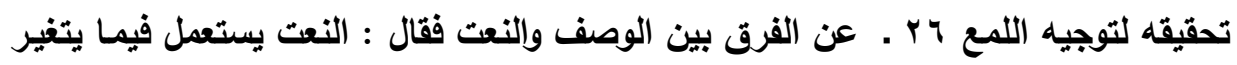

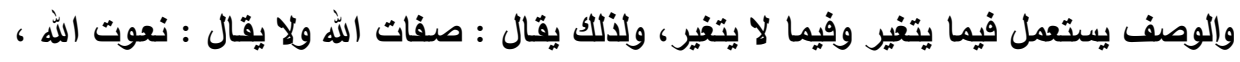

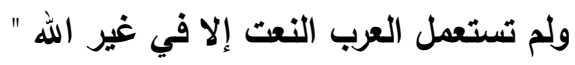


• فالمفرد يكون من الأسـماء المشتقة العاملـة ، وهـي مـا تدل على الحدث وصساحبه ـ كما سبق في باب الخبر . ، أمـا غير العاملة كاسمي الزمان والمكان واسم الآلة ، فلا ينعت بها ؛ لأنها لا تدل على صـاحب الحدث ، بل هي مشتقة

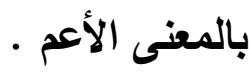

ومثُل هذا الوصف بالمصدر نحو " أقبّل رجلّ عدلّ ". جاء في الخصائص : " إذا وصف بالمصدر صار الموصوف كأنه في الحقيقة مخلوق من ذلك الفعل وذلك لكثرة تعاطيه لـه واعتياده إيـاه ، ويدل على أن هذا معنى لهم ومتصور في نفوسهم قوله :

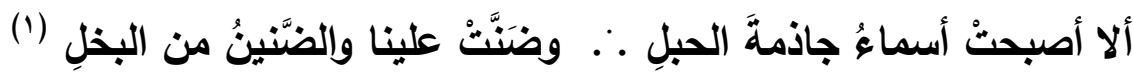
أي كأنه مخلوق من البخل لكثرة ما يأتي به منه .

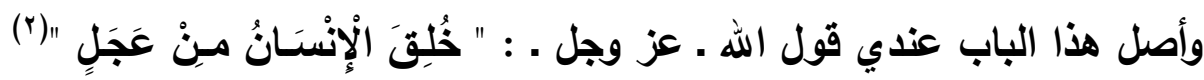
، وقوللك " رجل دنف " ، أقوى معنى لما ذكرناه من كونه كأنه مخلوق من ذلك الفعل ، وهذا معنى لا تجده ولا تتمكن منه مع الصفة الصريحة (r) .

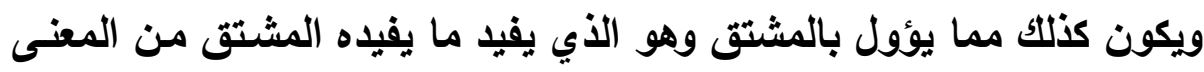
وهو المسمى بالمشتق تأويلاً ـ كما سبق هناك أيضا . .

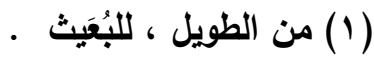

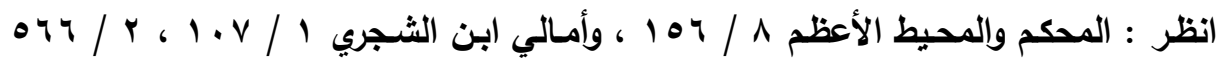

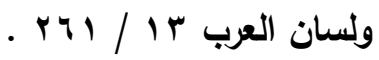

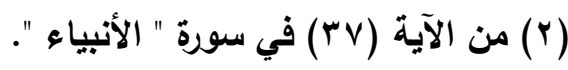

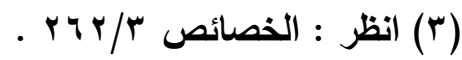


وإنمــا لـزم الاشــتقاق أو تأويلــه ؛ لأن المقصــود مـن الصـفة الفـرق بـين المشتركين في الاسم ، وذلك لا يحصل إلا بذكر المعاني العارضـة القائمسة بالذوات

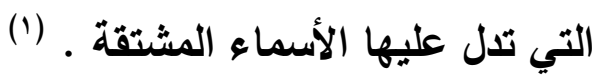
ويلزم هنا توافق النعت مع منعوته تعريفًا وتنكيرًا .

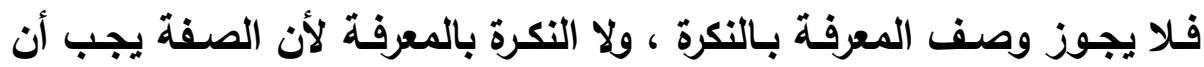
تكون على وفق الموصوف في المعنى ، فلو تخالفتا لـ يتحقق ذلك ؛ فالنكرة تدل على الشياع والعموم فهي كالجمع ، والمعرفة تدل على الاختصـاص فهي كالواحد فكمـا لا يوصـف الواحــ بـالجمع ، ولا الجمـع بالواحــ ، فكذلكك لا توصـف المعرفـة بالنكرة ، ولا النكرة بالمعرفة ، ووجب أن يوصف كل واحد منهمـا بمـا يلائمسه ، ومـا

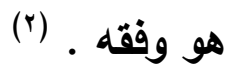

وقال الشاطبي : " وإنما لم تُعت النكرةُ بالمعرفة ، ولا المعرفةُ بالنكرة من جهة أن النعت والمنعوث في المعنى كالشيء الواحد ، والثيء الواحد لا يكون معرفةً نكرةً

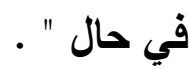
وإلى هذا المعنى أشار سيبويه بقوله : " زيدٌ الأحمرُ " عند من لا يعرفه كزيلدٍ عند من يعرفه . يريد : أن زيدًا الأحمرَ عند من لا يعرفه وحده بمنزلة زيد وحده عند

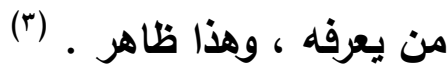

\section{الإقابل}

• والجملة هنـا تكون خبريـة ، ولا ينعت بها إلا النكرة ؛ لأنها مؤولة بالمفرد

النكرة .

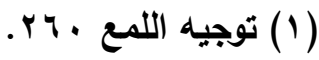

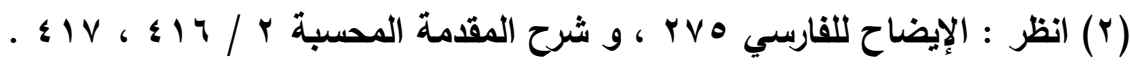

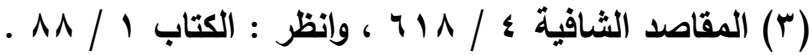


أ ـ فإن سمع ما ظاهره وقوعها طلبية فإنه يؤول تأويلا يُخرجها عن أن تكون

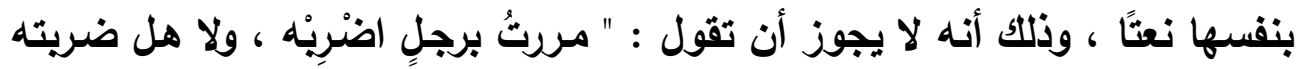

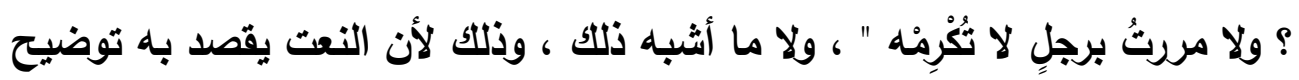

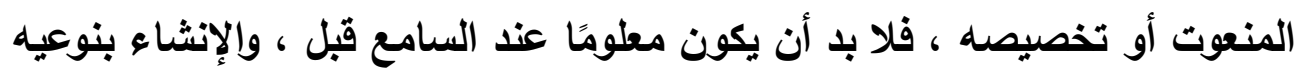

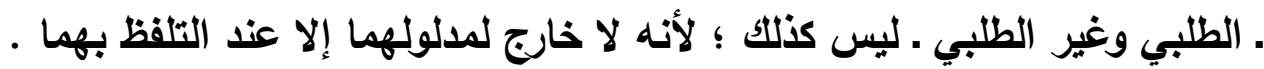

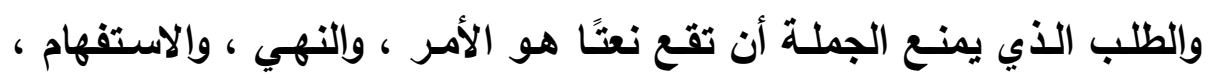

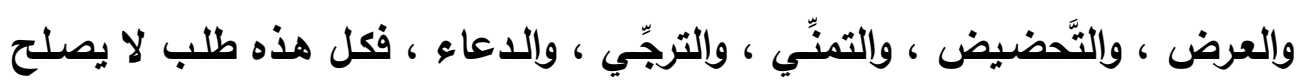

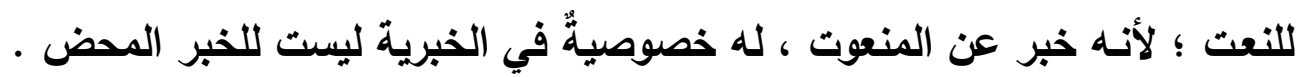

\section{ومما سمع من ذلك استفهاما قول العجاج :}

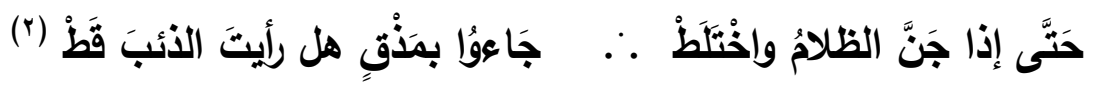

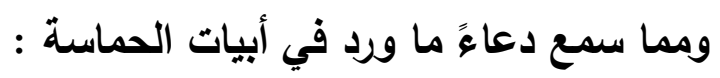

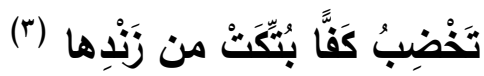

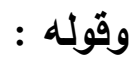

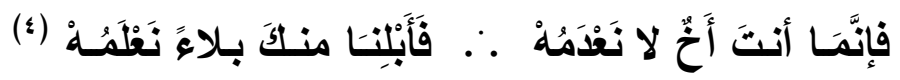

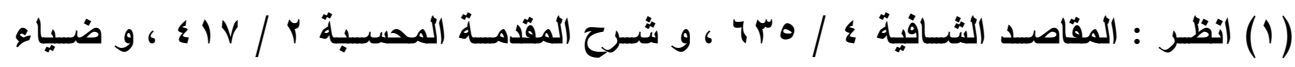

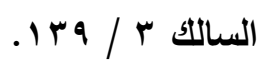

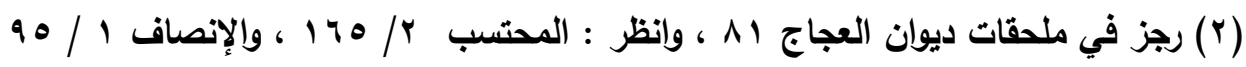

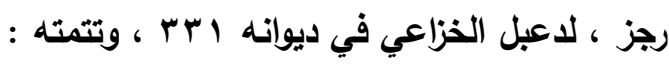

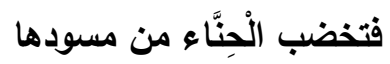

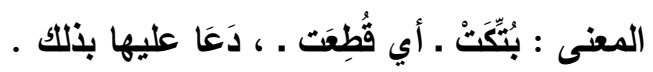

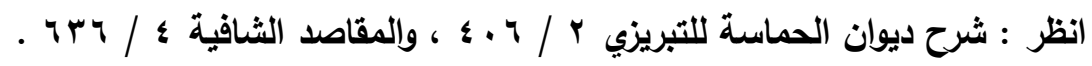

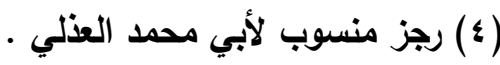


فهذا وغيره تجعل الجملةَ الطلبية فيه معولئة لقَول مقدَّر يقع صفة ، فتخرج

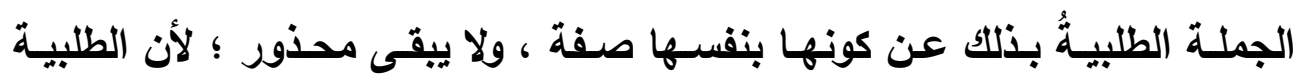

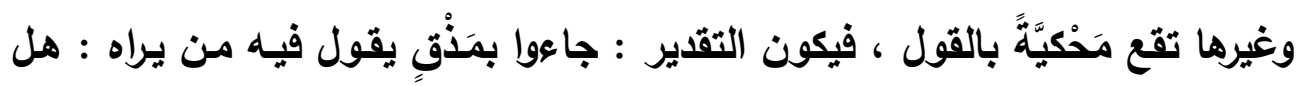

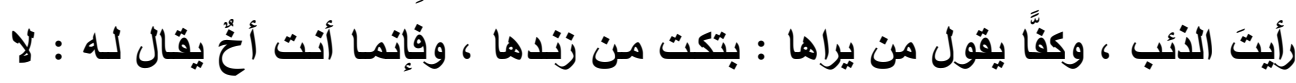

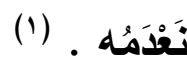

ب . وأما أنه لا ينعت بها إلا النكرة فلأنها تعطي معنى الاسم المشتق ، وهي

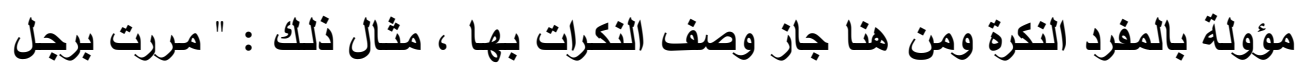

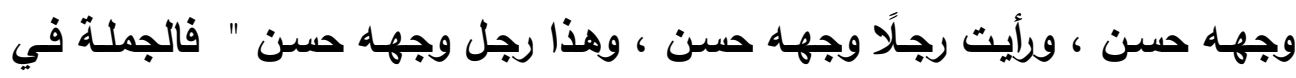

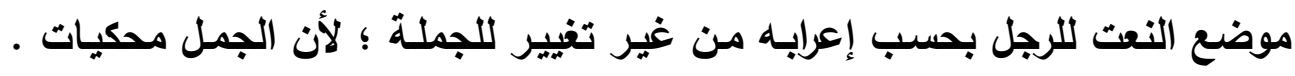

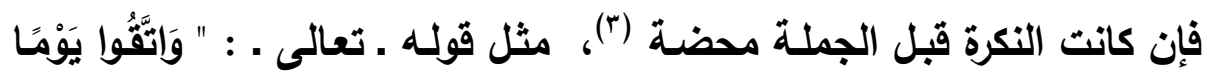

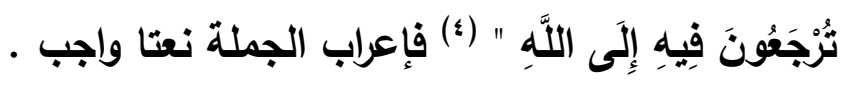

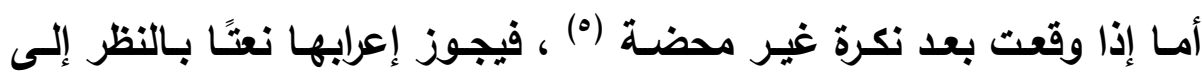

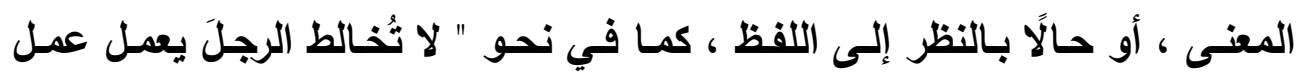

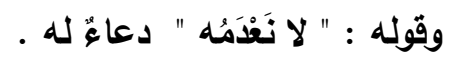

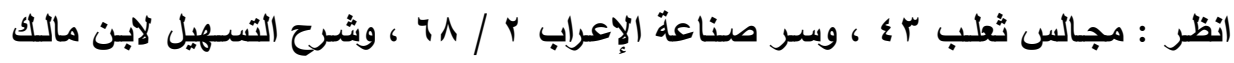

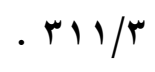

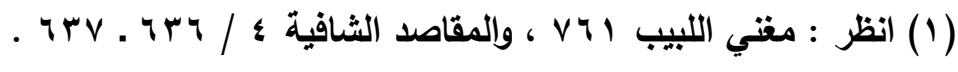

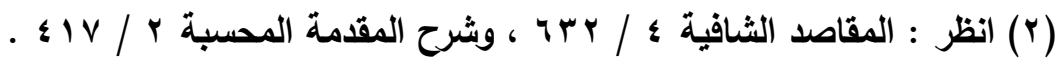

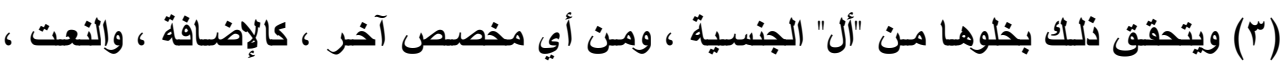

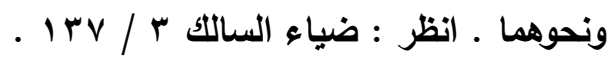

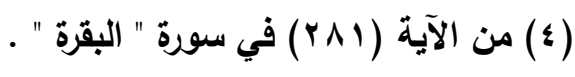

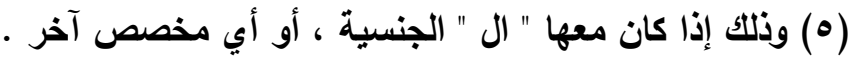


السفهاء " ؛ ف " ال " في " الرجل " جنسية وجملة " يعمل عمل السفهاء " يصح أن أن أنهاء

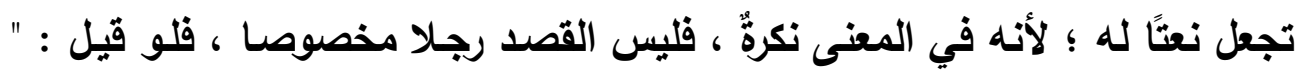

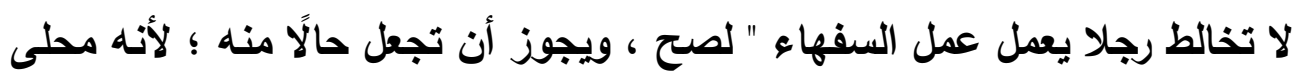

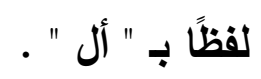

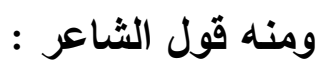

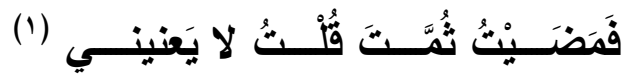

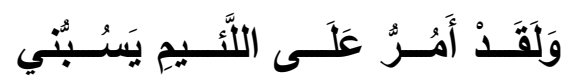

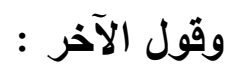

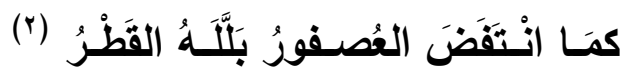

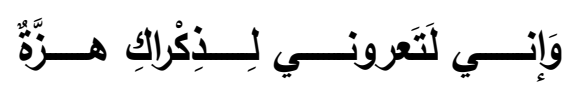

فليس القصد لئيما مخصوصـا ، ولا عصفورا مخصوصـا ؛ إذ لـو قيـل : لقد

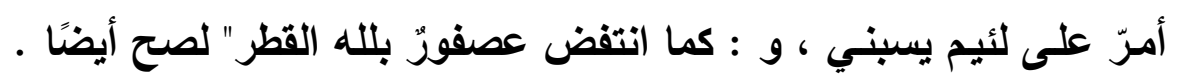

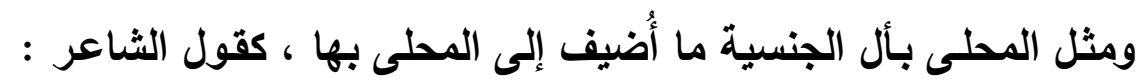

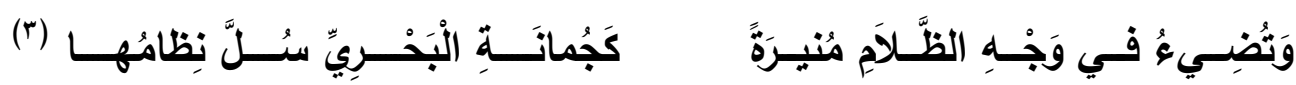

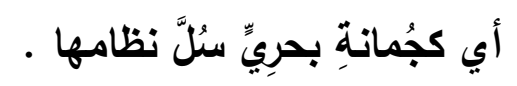

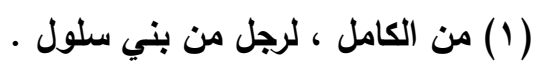

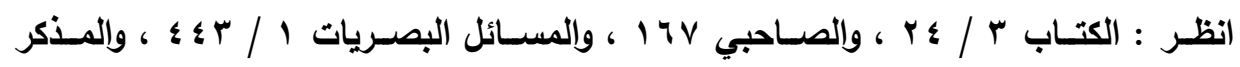

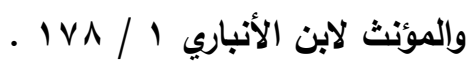

$$
\begin{aligned}
& \text { (r) من الطويل ، لأبي صخر الهألي . الأباري }
\end{aligned}
$$

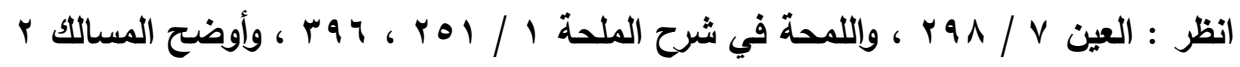

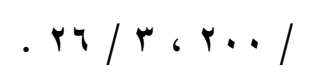

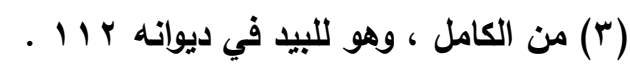

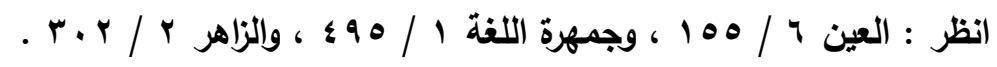


فالجملة الخبريـة إذا وقعت بعد نكرة محضـة أعربت نعتا ، أو بعد نكرة غير

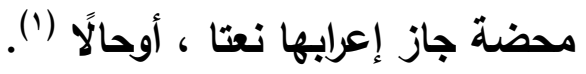

(1) انظر : جامع الدروس العربية ץ / צr ب . 


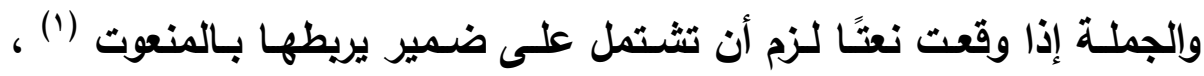

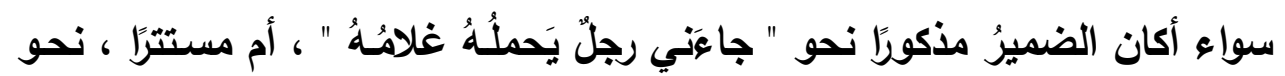

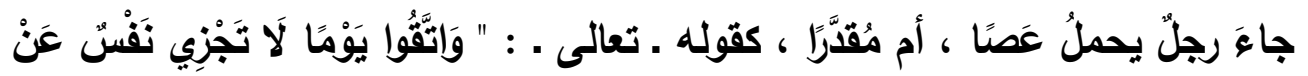

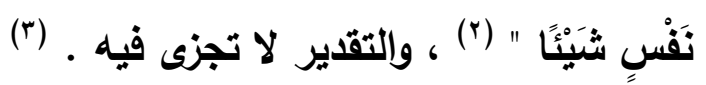
والوصف بالجملة الفعلية أقوى منه بالاسمية .

وإذا كانت جملة النعت فعلية بعد مبتدأ هو ضمير للمتكلم أو للمخاطب ، جاز في الضـمير الرابط أن يكون للمـتكلم أو للمخاطب ، وأن يكون للغائب يقـال : أنـا

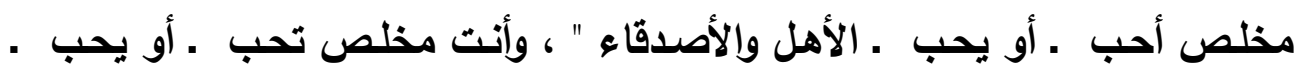

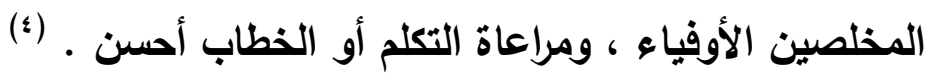
وإذا جمعت بين الجملة والمفرد فالجيد تقديم المفرد كقوله ـ تعالى . : " وَهَذَا

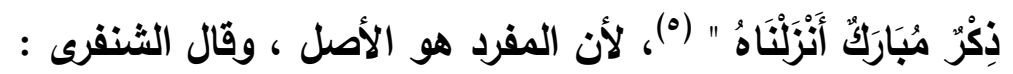

(1) وقد تغني " ال " عند بعض النحاة عن الضمير الرابط إذا دخلت على الجملة الاسمية الواقعة

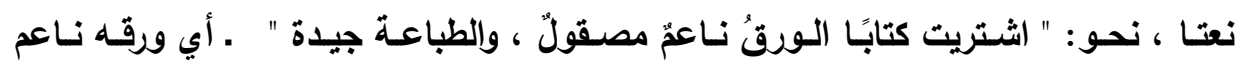
وطباعته جيدة ـ وهو مسموع كثيرا يصح القياس عليه إذا أمن اللبس . ولا تصلح الواو التي تسبق جملة الوصف للريط ، بخلاف الجملة الحالية ، بل هي تزاد أحيانًا

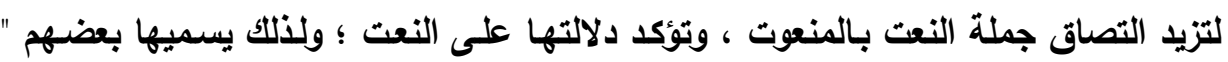

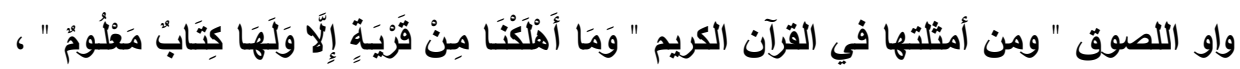

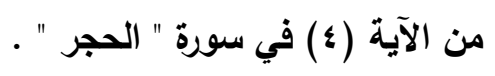

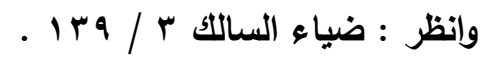

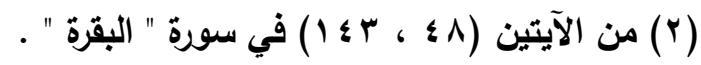

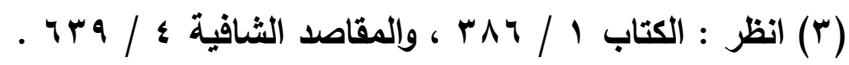

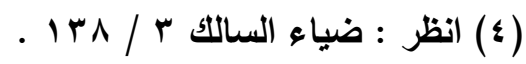

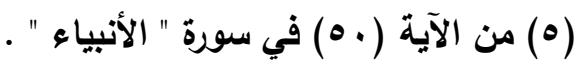




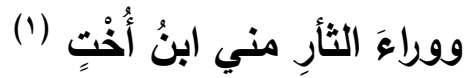

• وشبه الجملة أن يقع الظرف ، أو الجار والمجرور بعد نكرة محضة ، مثل أنل "

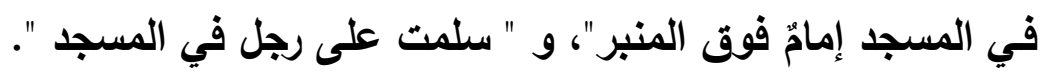
والقول في شبه الجملة هنا هو القول في شبه الجملة في بابي الخبر والحسال

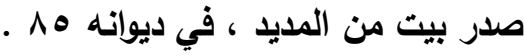

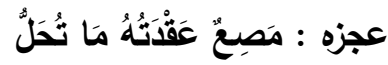

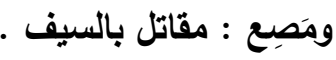

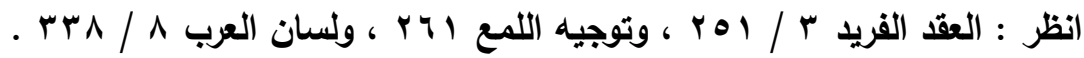




\section{الفرده في باب " لاب " النافية لابنس}

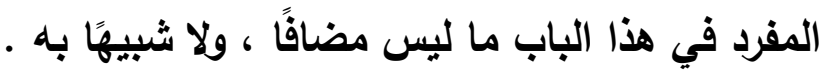

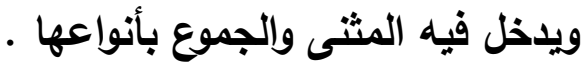

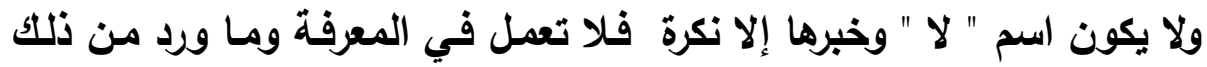

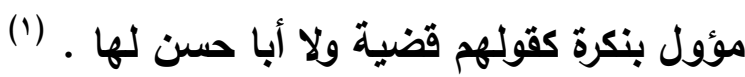

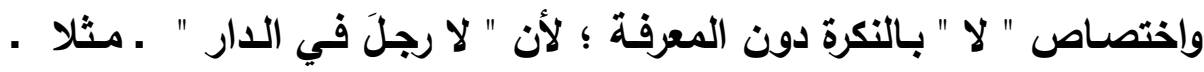

جواب لمن سأل : " هل مِنْ رجلٍ في الدار ؟ " ، والذابي يقع بعد " مِنْ " في السؤال

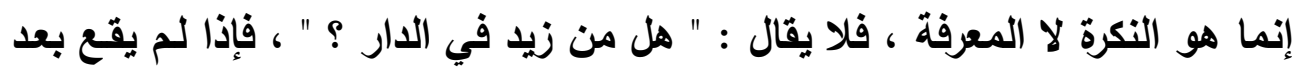

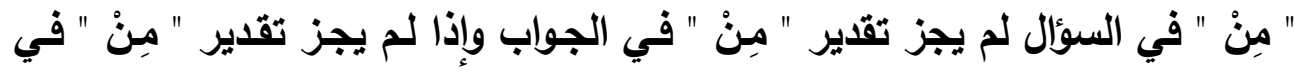
الجواب لم تتضمن المعرفة معنى الحرف فوجب أن يبقى على أصله في الإعراب .

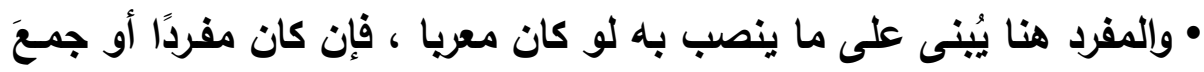

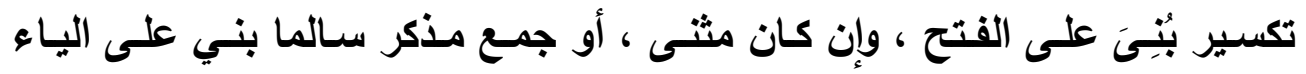

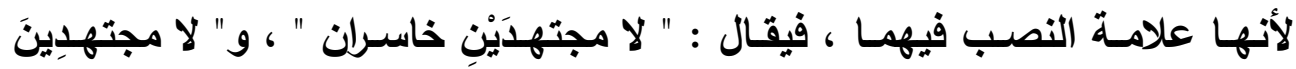

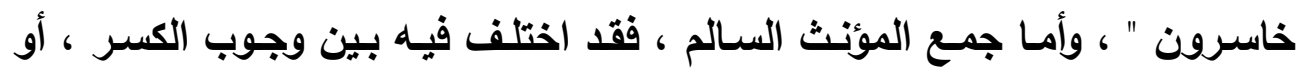

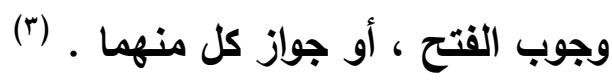

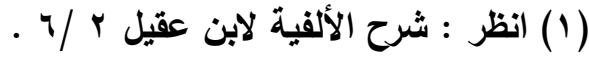

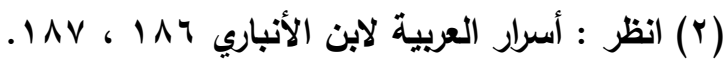

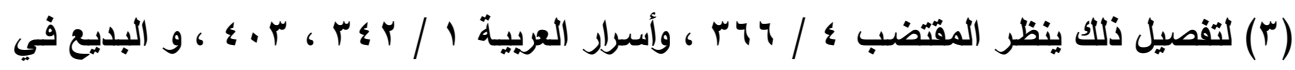

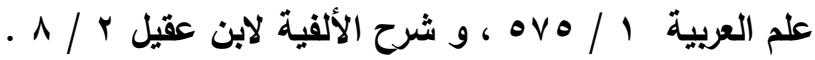




\section{الإقابل}

والمقابل للمفرد في هذا الباب هو المضاف والثبيه به .

أولَُ : الاغناف

وهو الاسـم الذي ينضـم إليـه اسـ آخر مجرور بعده يكمل بـه معنـاه ، وهو

المضاف إليه .

وإن كانت الإضافة معنوية وجب أن يكون المضاف إليه نكرة مثل : " لا طالبَ

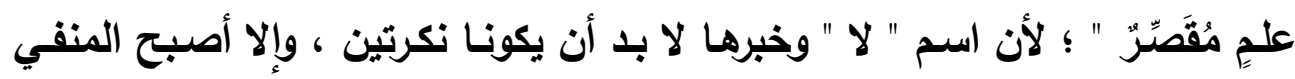
هنا معرفة ، وخرج من هذا الباب . ويشمل المضاف ما فصل فيه بين المضاف والمضاف إليه باليلام الزائدة ، مثل من " لأبا للك "

قال الصبان : " ودخل في المضاف مـا فصل باللام المقحمـة بين المضاف و المضـاف إليهه نحو " لا أباً لك ، ولا أخـاً لك ، ولا غلامسي لك ، ولا يـدي لك " بنـاء على مذهب سيبويه والجمهور أن مدخول " لا " مضاف حقيقة إلى المجرور باللام

واسـم " لا " هنـا لا يكون مبنيـا كمـا كان في المفرد ؛ لأن علـة البنـاء هنـاك كانت تركب " لا " مـع اسمها ، وهي هنا ممتنعة ؛ لتعذر تركب ثلاثة أشياء ، هي " لا " ، والمضـف ، والمضاف إليه ، فامتتع التركيب لطول الاسم ، وكذلك الشبيه بـه

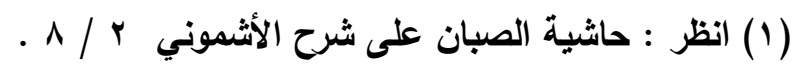

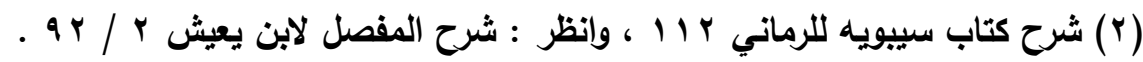


وقال الرضـي : " ولــم يُبْنَ المضـاف ، ولا المضـارع لـه ؛ لأن الإضـافة ترجح جانب الاسمية فيصير الاسم بها إلى مـا يستحقه في الأصل ـ أعني الأعراب ـ ولا

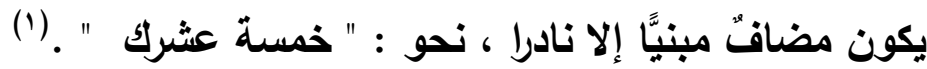
أما العكبري فقد قال : " وإنَّما خالف هذا الاسم النكرة المفردة لثنلاثة أوجه : أحدها : أن المضـاف والمضـاف إليه كالثـيء الواحد وهما في اللفظ اسمان فلو بنيت الأسم الأول مـع " لا " لكان لعلة التركيب فتصير ثلاثة أشياء كالشيء واحد

والثاني : أنّ المضاف إليه واقع موقع التتوين وكما أن التنوين لا يكون بعد حركة البناء كذلك المضاف إليه . والثالث : أن المضـاف عامـل في المضـاف إلبهه وقد ألُّفَ من كل مبني إذا أضيف إلى مفرد أعرب ، فأما " لان " فبنيث مـع الإضـافة لإيغالها في شبه الحرف

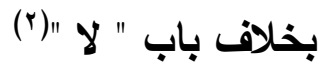

\section{(v) : قانيا : الشبيه بالاكغافه}

وهو ما اتصل به شيء من تمام معناه ، فهو متعلق بما بعده ، إمـا بعمل ،

أوعطف .

فالعمل إما رفع ، أو نصب ، أو جر بالحرف ، فالرفع نحو " لا محمودًا فعلُه

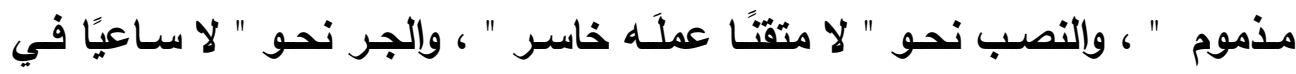

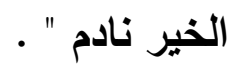

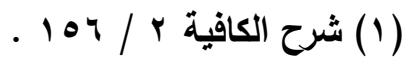

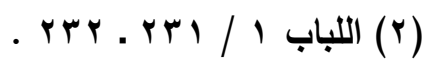

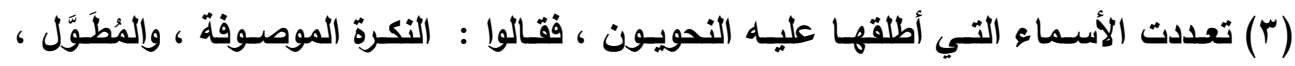

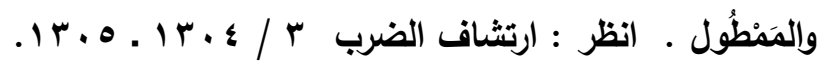


والعطف نحو " لا ثُلاثةً وثثلاثين عندنا " .

ويلخل فيه ما وصف بمفرد معرف أو منكر ، أو بجملة ، أو بظرف . قال ابن مالك في التسهيل : " ويجوز نصب ما وصف من معرف بقصد وإقبال

(1)."

قال الصبان : " وعلى هذا لا يختص الشبيه بالمضاف بما عمل فيمـا بعده ،

أو عطف عليه ما بعده ".(r)

وقال السيوطي في باب النداء ـ من الهمع . : " أما الموصوفة بمفرد أَو جملَة

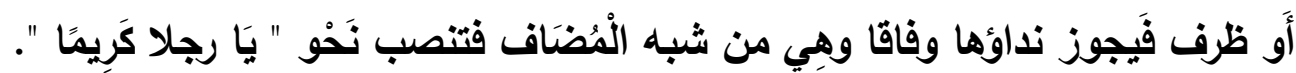

وهذا القسم أشببه المضـاف في أن الجزه الأول منـه عامـل في الثاني ، وأن الأول خُصِّص بالثاني ، وأن الثاني من تمـام الأول ، وهذه كلهـا أمور متحققة في التهي المضاف ولكنه في الوقت نفسـه لـ تتحقق فيه صفات المضاف لفظًا ، وليس في قوتنه معنى

وقد يلتبس بالمفرد ويفرق بينهما لفظا ـ فهو منصوب منون ، والمفرد مبني على ما يرفع به . ، ومعنى ، فمعنى الجملة يختلف في كل منهما عن الآخر فــع

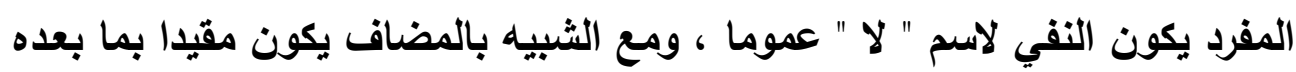

قال سييويه: " وقال الخليل . رحمه الله . : كذلك " لا آمِرا بالمعروف لك " إذا

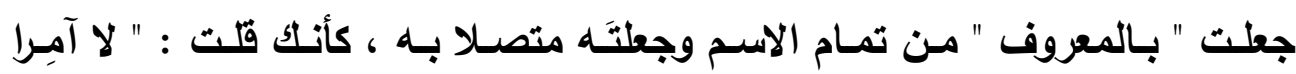

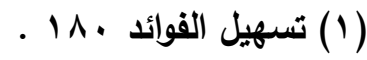

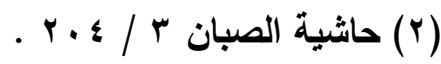

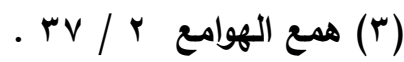


معروفا للك " ، وإن قلت : " لا آمرَ بمعروف " ، فكأنك جئت بمعروف بعد ما بنيتَ

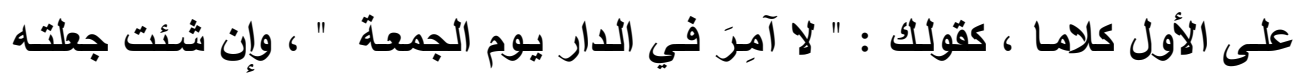

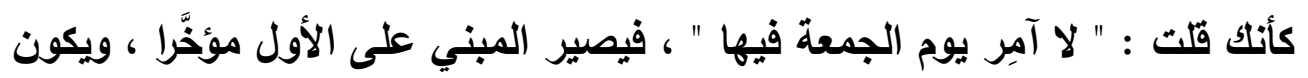

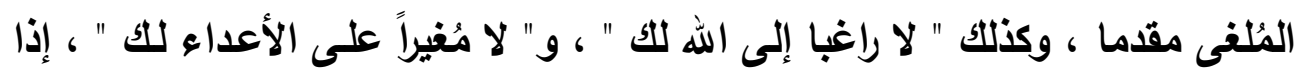

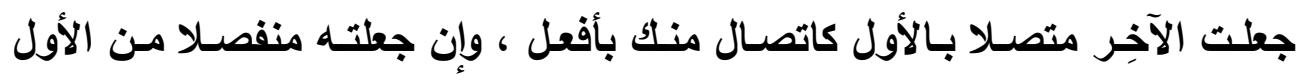

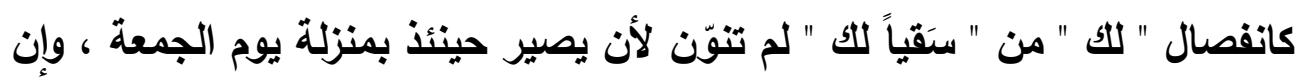

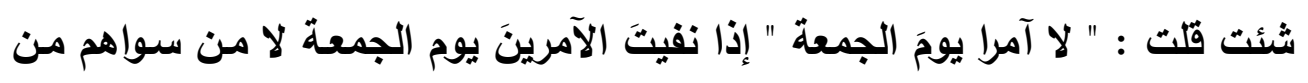

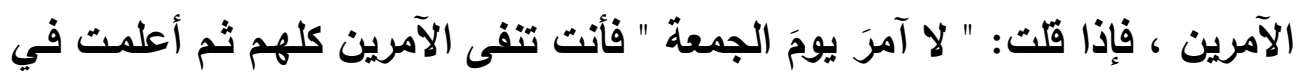

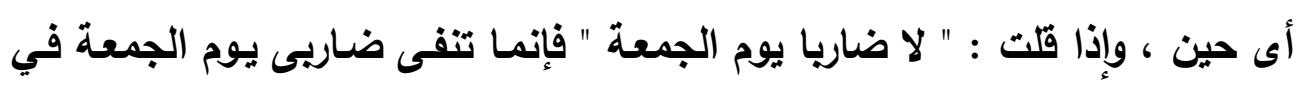

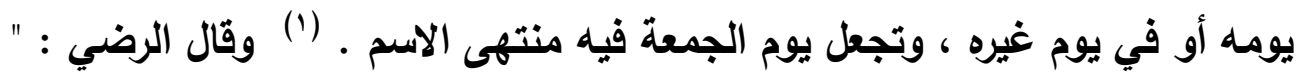

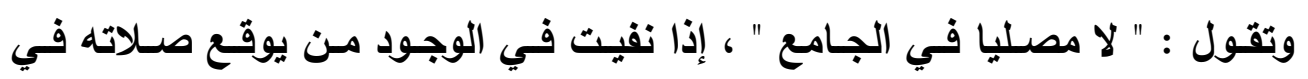

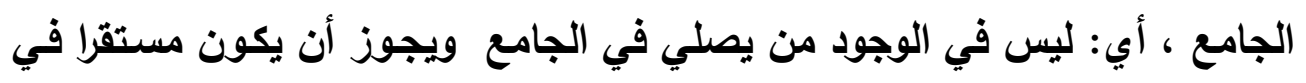

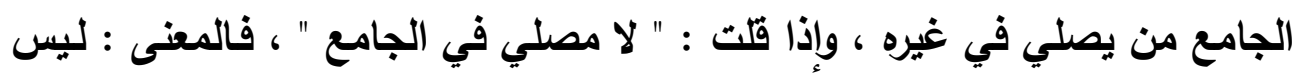

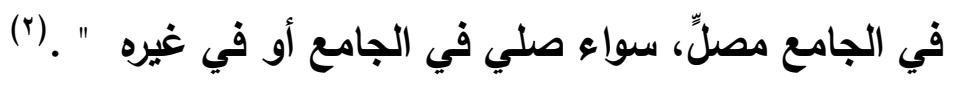

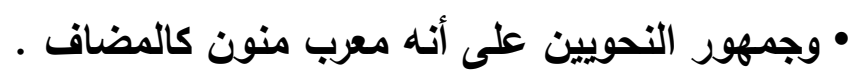

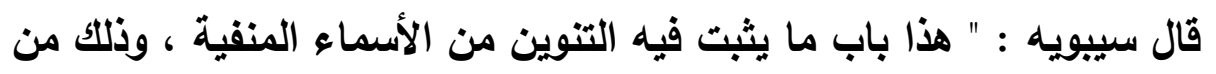

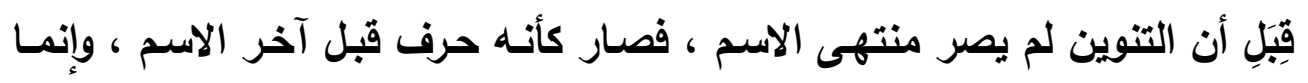

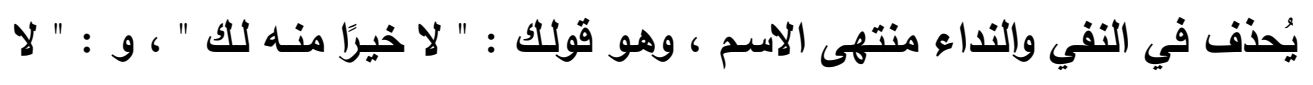

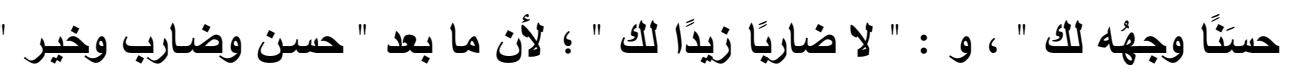

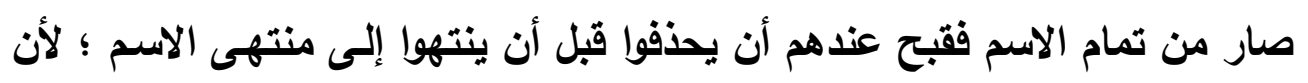

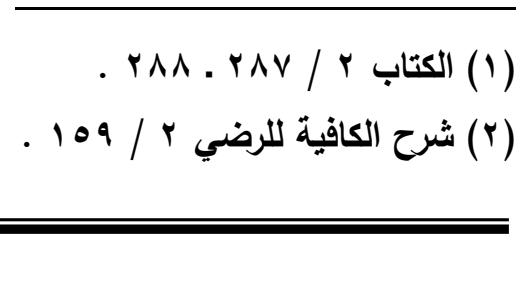


الحذف في النفي في أواخر الأسماء ، ومثل ذلك قولك : " لا عشرين درهما للك ". "

• وأجاز (بن كيسان حذف تنوينه ، وهذا عنده أحسن من إثباته ، ونسب

هذا للبغداديين • (r)

كما نَسَب إليهم أبو حيان ، والسيوطي جوازَ بنائه إن كان عاملا في ظرف أَو

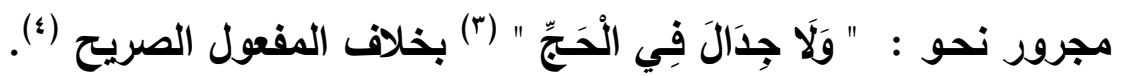
قال ابن هشـام : " وهو ـ أي ترك تنوين الشبيه بالمضاف ـ قََول البغداديين

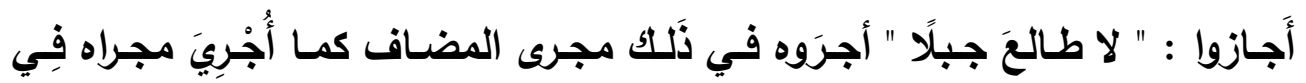

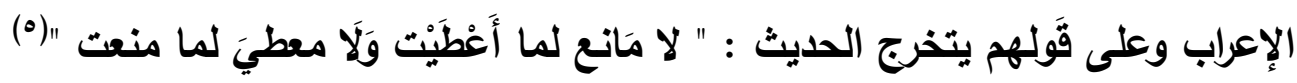
وأما على قول البصريين فَيجب تتوينه ولكن الرواية إنما جاءت بغير تتوين . " (") قال الدماميني : " وأما على قول البصريين فيجب تنوينه ، ولكن الرواية

(Y) يقولون : كما حمل على المضاف في الإعراب ، حمل عليه في ترك التنوين .

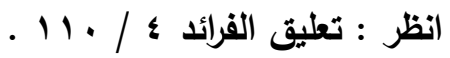

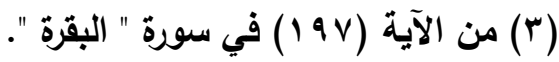

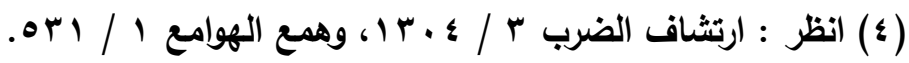

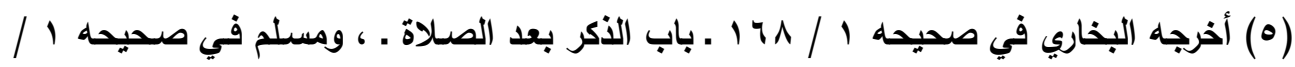

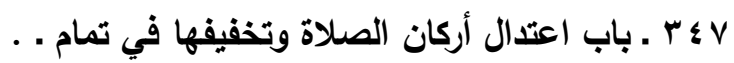

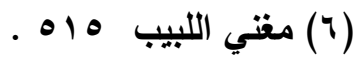


إنما جاءت بغير تنوين (1) وحكم ابن مالك على ذللك بالقلة ، واستدل له بقول الشاعر :

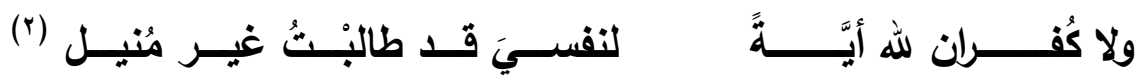
أرانـــ • وذهب الكوفيون إلى إجازة بناء الشبيه بالمضـاف فقالوا : لا ضسارب ضريًا

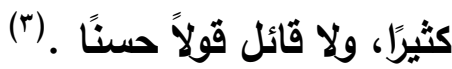
الفرد في باب التميهز :

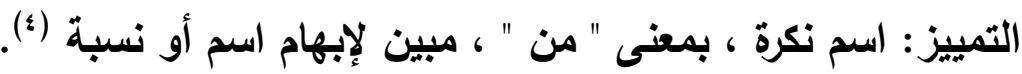
قال أبو حيان : " وهو قسمان : الأول منتصب عن تمام الكلام ، وهو ما كان الإبهام فيه حاصـلا في الإسناد ، ومنتصب عن تمـام الاسم ، وهو مـا كان الإبهام حاصلًا في الاسم الأي هو جزء كلام (•).

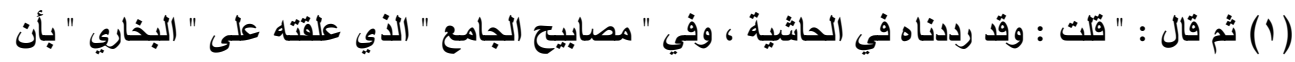

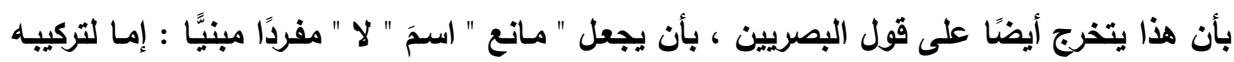

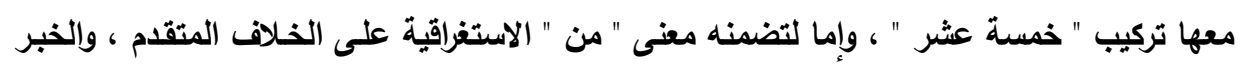

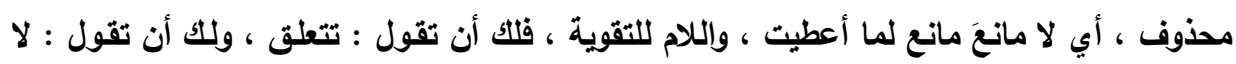

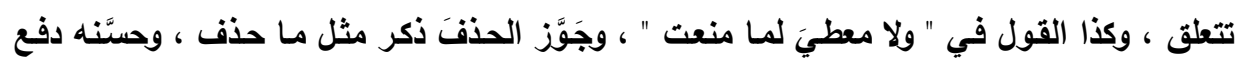

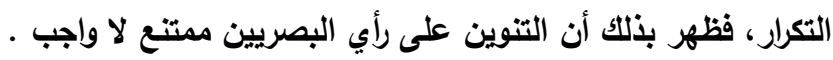

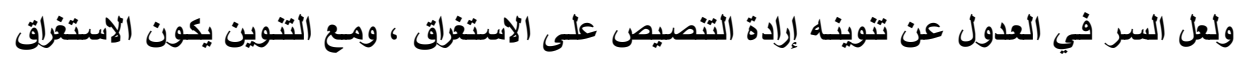

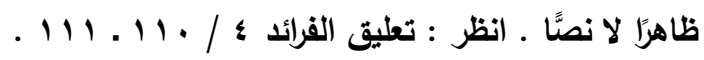

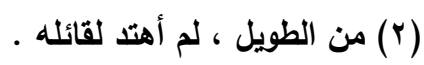

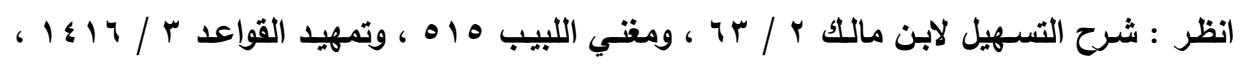

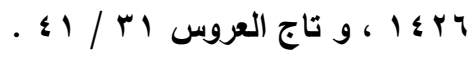

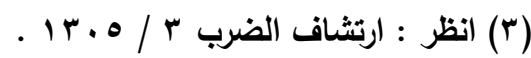

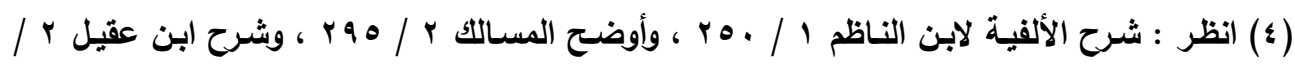


والكلام هنا عن المبهم الذي يفسره هذا التمييز (') ، فإن جاء التمييز بعد تمـام الاسم فهو تمييز المفرد ، مثل " اشتريت رطلا سمنًا " ، وإن جاء بعد تمـام الكلام فهو تمييز النسبة ، مثل " طاب زيد نفسًا " . • فالمفرد في هذا الباب هو ذات ملفوظ بها ولذلك يسمى الأات،أو الملقوظ . والمقصود به هنا ما ليس نسبة وإن كان مثنَّى أو مجموعًا أو مركبًا أو مضافًا

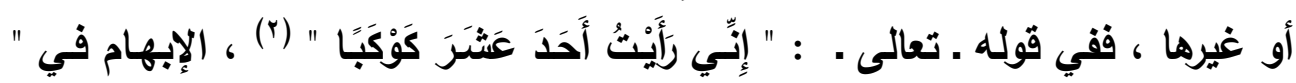

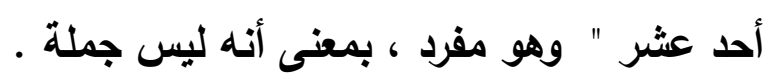
وهذا المفرد المبهم أريعة أنواع :

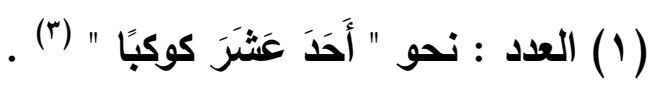

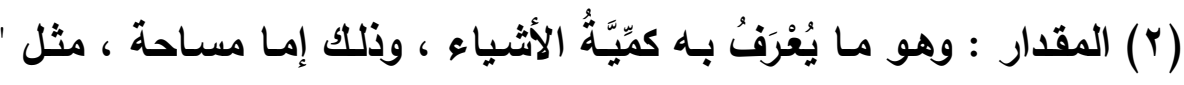

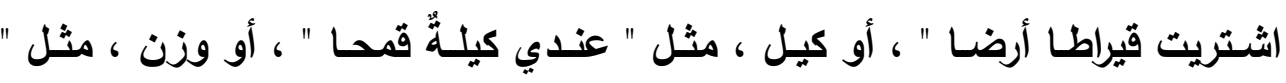
اشتريث رطلا سمنا " الثربت

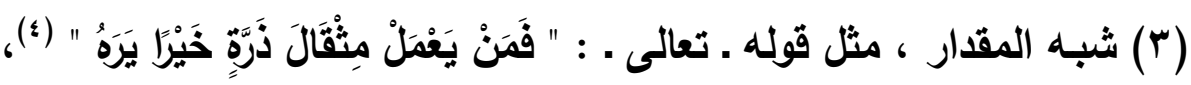

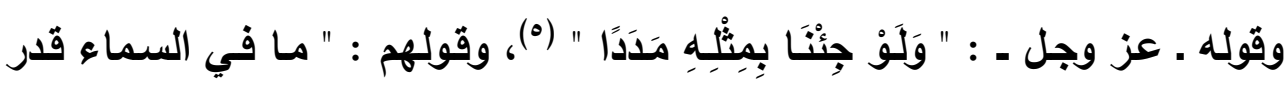

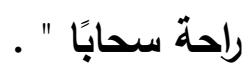

(ع ) ما كان فرعا للتمييز ، وهو كل فرع حصل لـه بالتفريع اسم خاص يليه

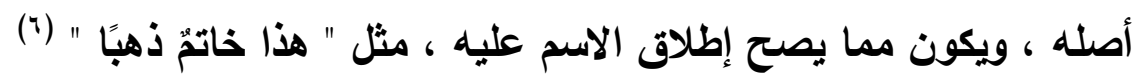

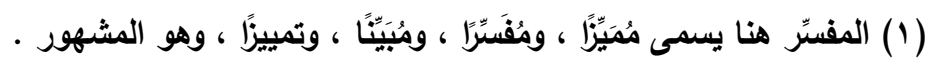

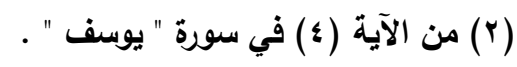

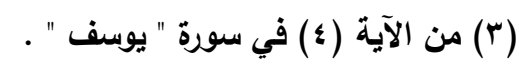

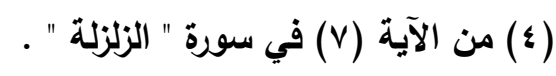

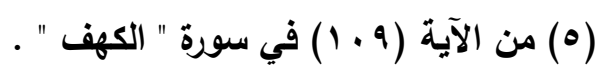

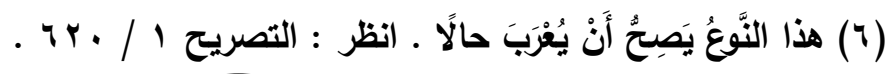


والناصب للتمييز في هذه الأنواع هو ذلك الاسم المبهم ـ وإن كان جامدًا .

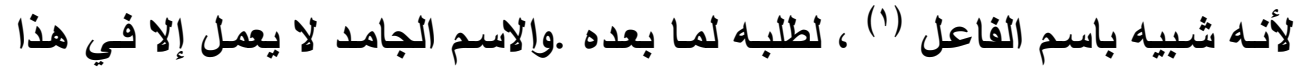

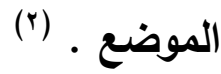

\section{إلمقابل}

• ويقابـل المفـرد هنـا النسبة أو الملحسوظ ؛ إذ لا يكون التفسير فيـه لشـيع

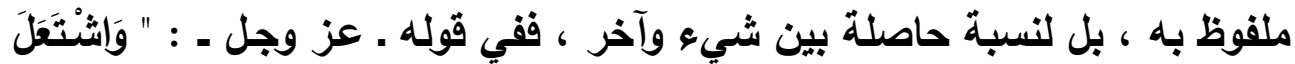

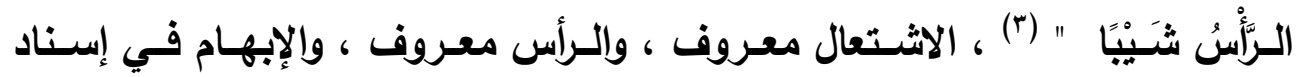

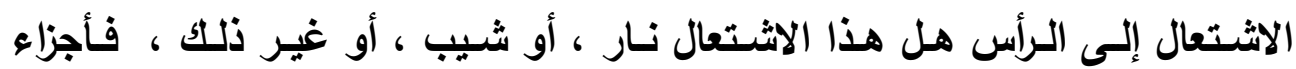
الجملـة لا غموض فيها ، ولكن الغموض في إسناد بعضهها إلى بعض ، فجاءت

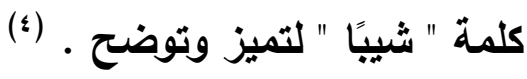

(1) ففي نحو : " اشتريت رطلازيتا " أثبه اسم الفاعل المفرد في نحو: " زيد ضـارب عمرا " ، وفي نحو : " اشتريت عشرين ثويا " أثبه اسم الفاعل المجموع في نحو : " هؤلاء الضاريون

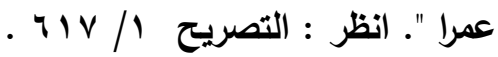

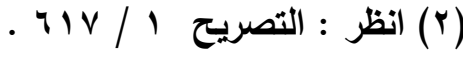

$$
\begin{aligned}
& \text { (؟) من الآية (ع) في سورة " مريم " . }
\end{aligned}
$$

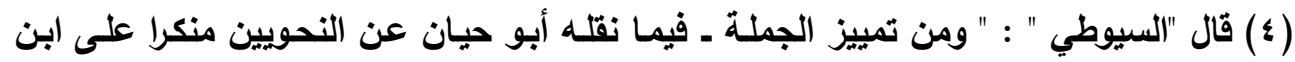

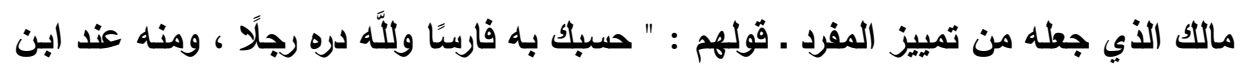

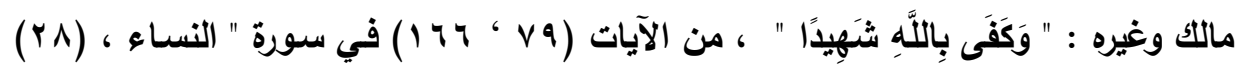
في سورة " الفتح ".

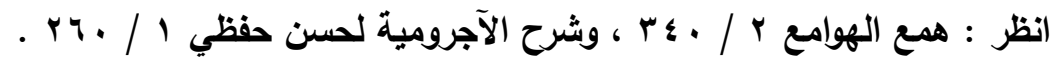


والنسبة المبهمة المقابلـة للمفرد في هذا الباب إمـا أن تكون نسبة الفعل

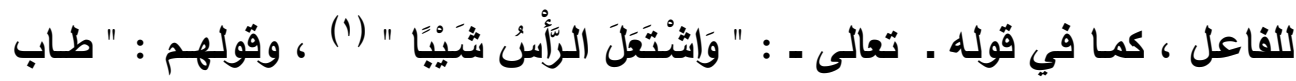

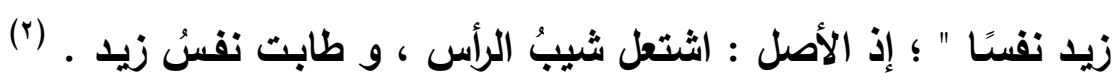

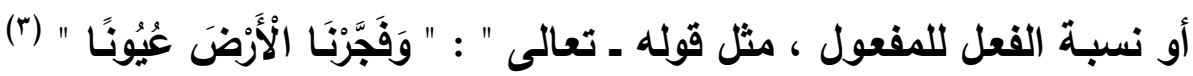

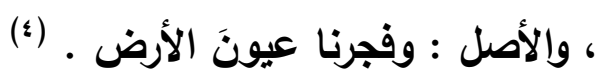

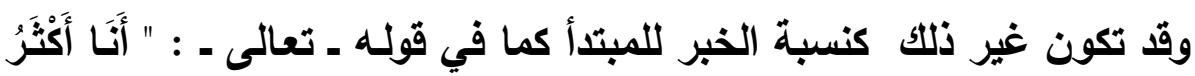

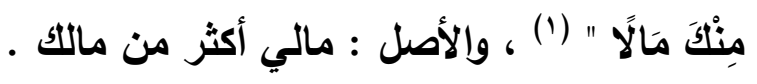

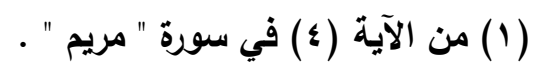

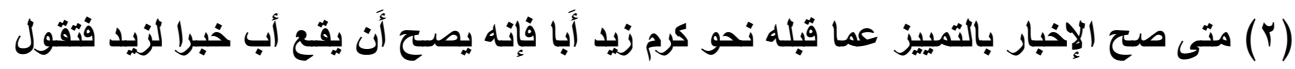

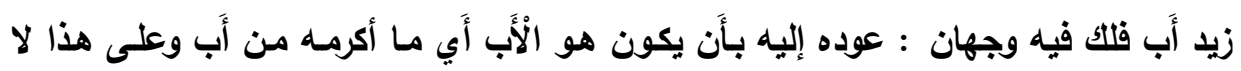

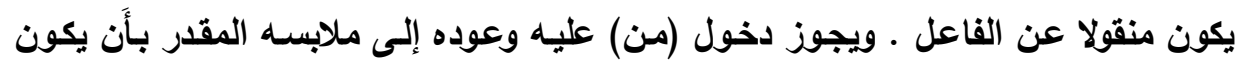

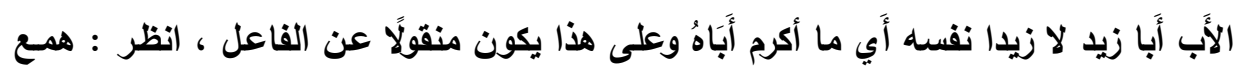

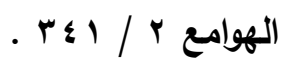

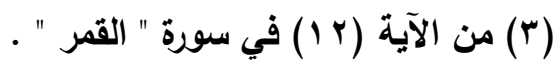

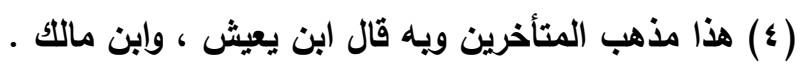

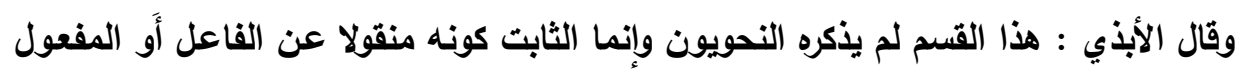

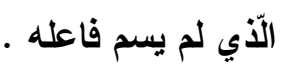
وقال الثلوبين : " عيونا " في الآية نصب على الحال المقدرة ، لا التمييز، ولم يثبت كون

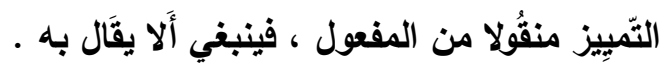

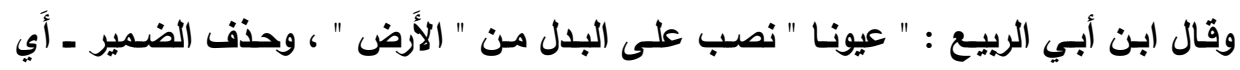

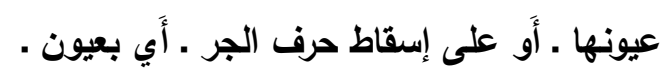

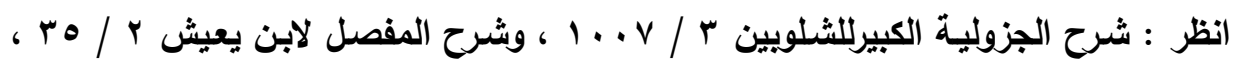

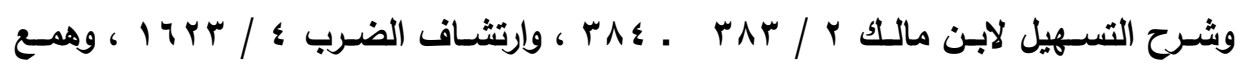

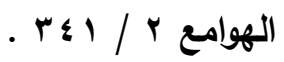


وفيما سبق نجد أن الاسم المنصوب الذي بَيَّنَ الإبهام كانت لله وظيفة في في

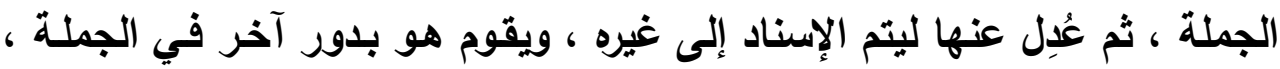
وهذا ما يعرف بالتمبيز المحول . وقد يكون غير محول نحو " لله دره فَارِسًا " (r) . وجاء في كتاب سيبويه : " هذا باب ما ينتصب انتصاب الاسم بعد المقادير "ل

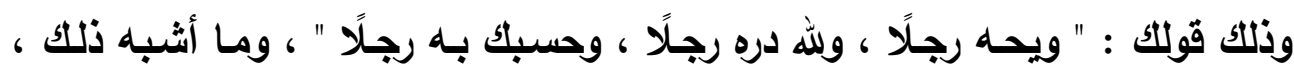

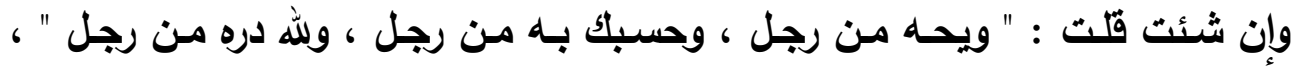

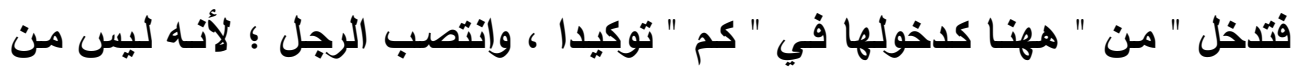

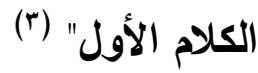

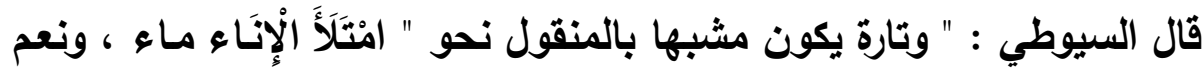

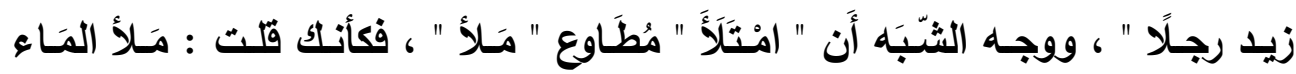

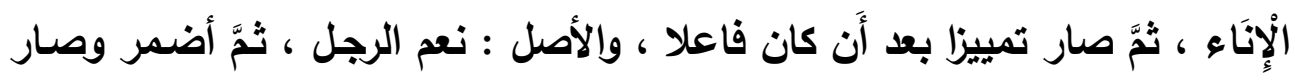

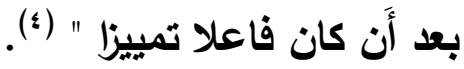

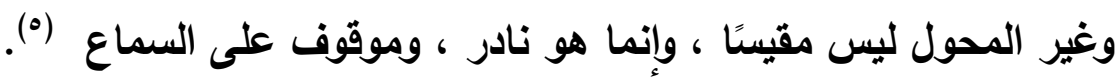

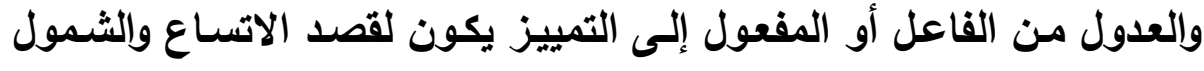

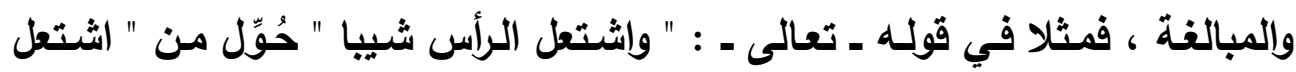

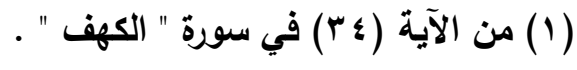

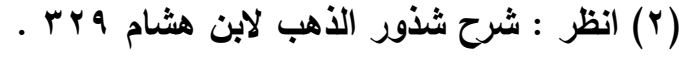

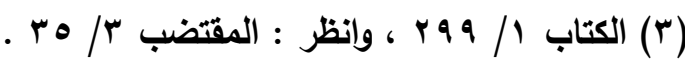

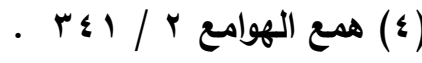

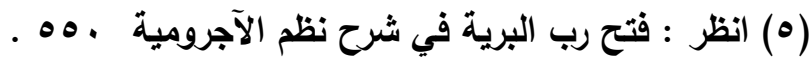


شيبُ الرأس " ؛ ليتحول المغنى من الدلالة على شيب متفرق في الرأس إلى أن الرأس قد امتلأت. وفي قولهه ـ تعالى ـ : " وفجرنـا الأرض عيونـا " تحول المعنى من أن الماء

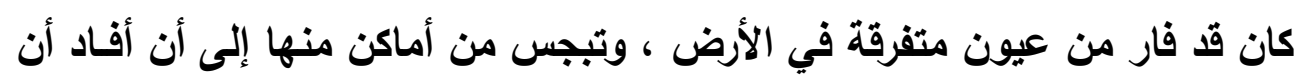

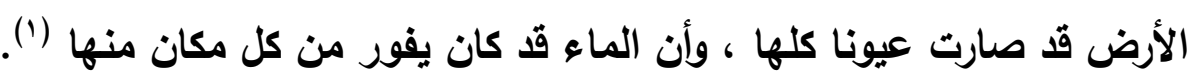

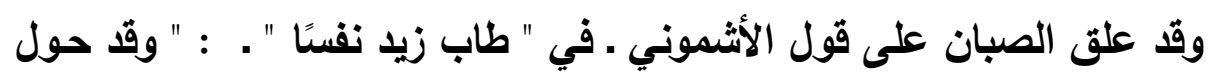

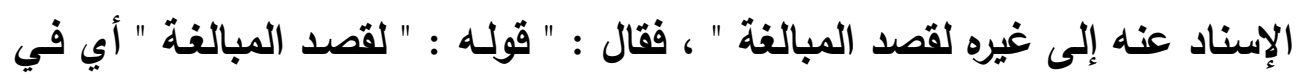

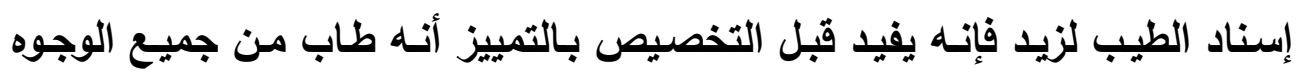
فالمبالغة من حيث أول الكلام .

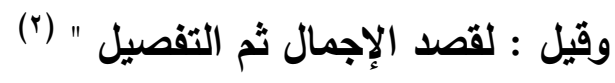

ويالتالي يمكن القول ـ في الفرق بين " طابت نفسُ زيد " ، و و " طاب زيل

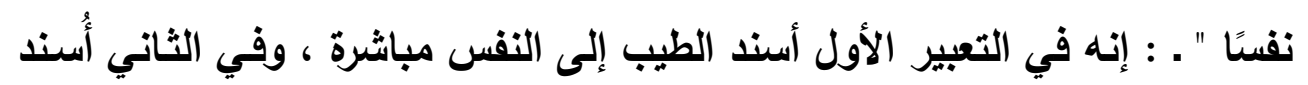

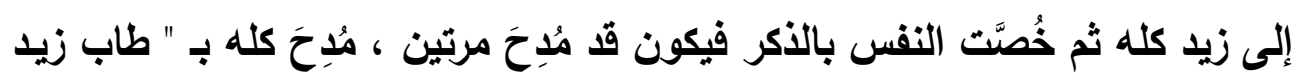

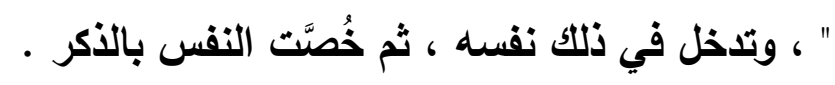

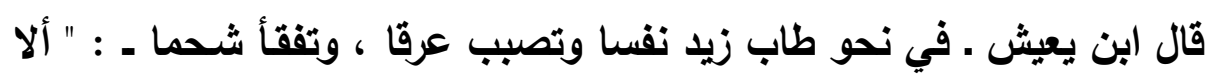

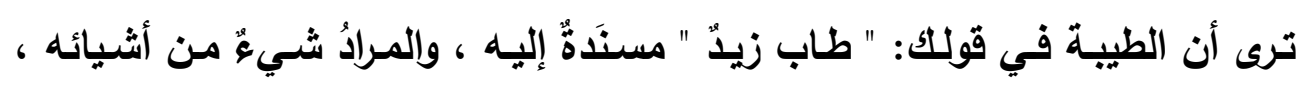

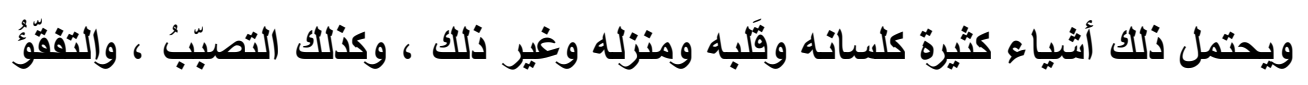

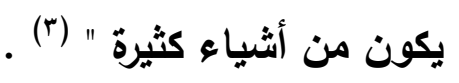

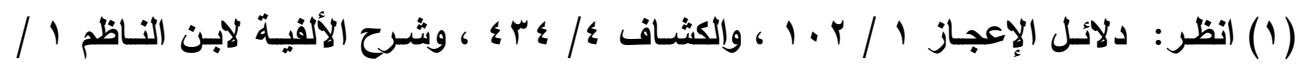

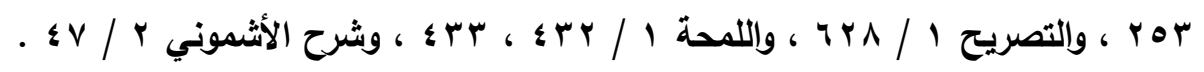

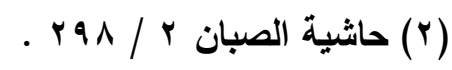

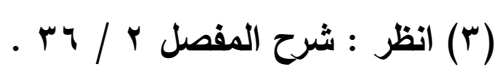




\section{الفرد في باب النداء}

والمراد بـه هنـا : مـا ليس مضـافًا ولا شبيهًا بـه ، فيدخل فيه المفرد والمثنى

والجمع ، وذلك مثل " يا عمرُو " ، و" يا نائمان " ، و" با تُجّارًا " . ويشمل المفرد في هذا الباب العلم مثل : " يا محمدُ " ، والنكرة ، وهي قسمان

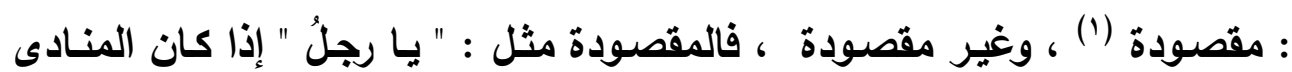

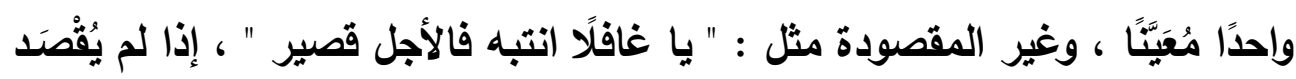
واحد بعينه

ويلحق بالمفرد هنـا اسم الاثارة والاسم الموصول ، نحو : " يـا هذا " ، و" يـا

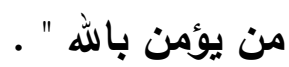
أما إذا اتصل اسم الإثارة بكاف الخطاب فنداؤه مختلف فيه . قال أبو حيان : " وفي ندائهـ مشـارًا مصحويًا بحرف الخطاب نحو : " بـا ذاكت خلاف " ، منع من ندائه السيرافي ، وهوموافق سييويه في كلامه أن أولئك ينادى ،

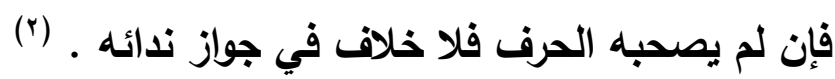

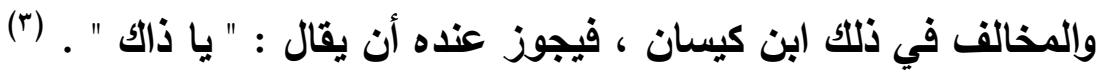
ومنع الجمهور نداء الضمير ، وإن كان هناك من أجاز نداء ضمير المخاطب

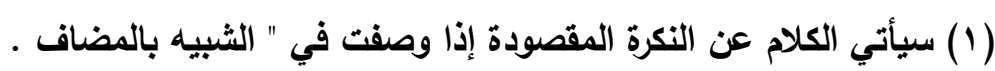

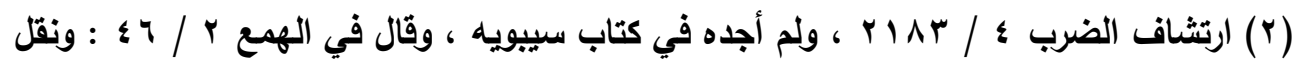
عن سيبويه . المان.

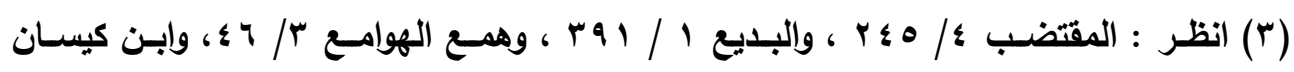

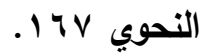


قال السيوطي : " لَ يُنَادى الضَّمِير عِنْد الْجُمْهُور ، وَأما ضمير الْفَيَبَة والتنكلم

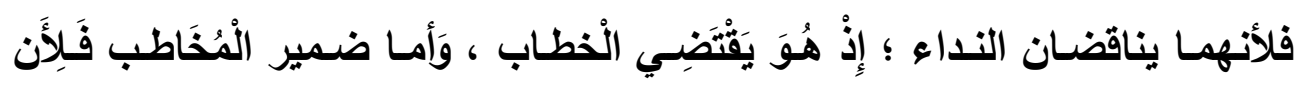

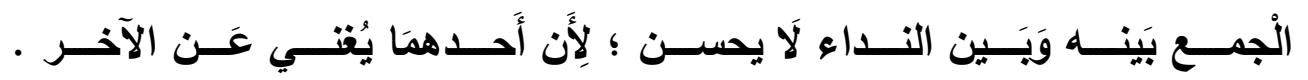

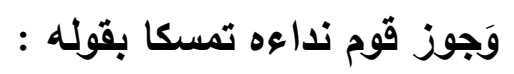

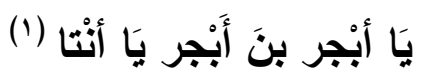

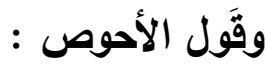

يَا إياك قد كفيتك (r)

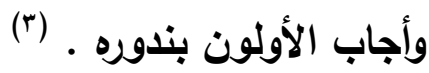

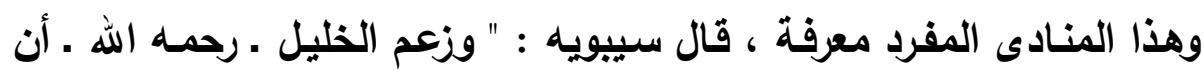

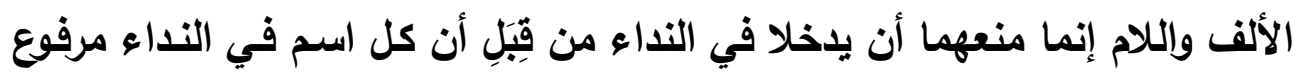

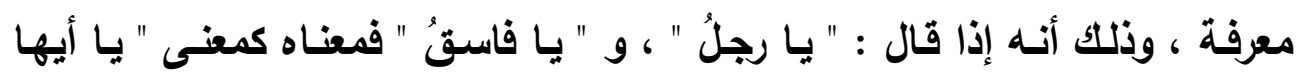

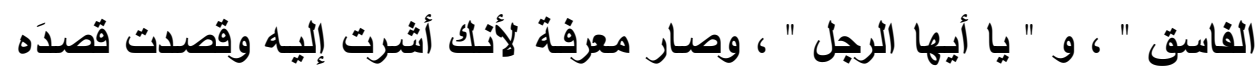

\section{(1) رجز ، للأحوص في ملحقات ديوانه ه بr ، ويعده :}

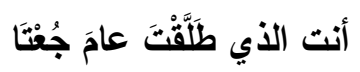

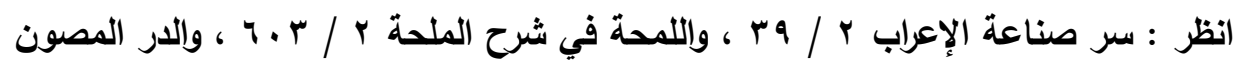

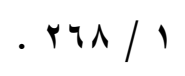

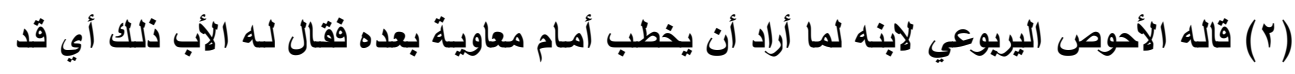

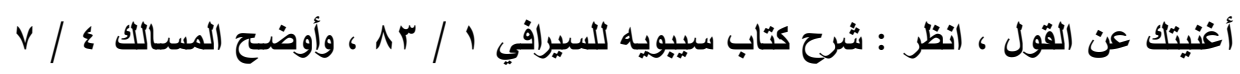

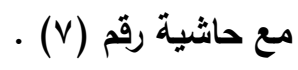

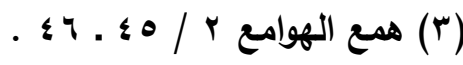

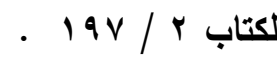


فالنكرة المقصودة مُعَرَّةة بالقصد ، وقيل : بـ " ال " محذوفة ونابت عنها " يا

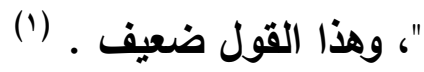
أما العلم فمختلف في مُعرَّفهه :

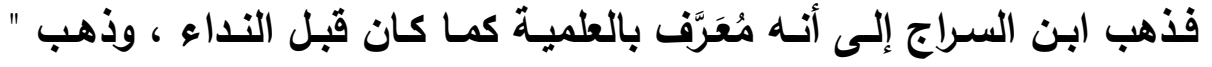

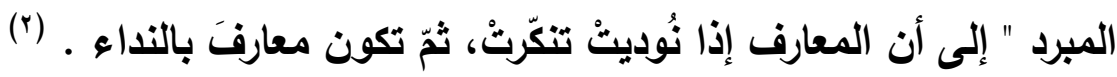

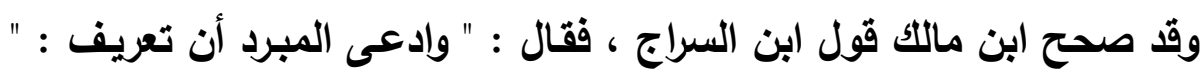

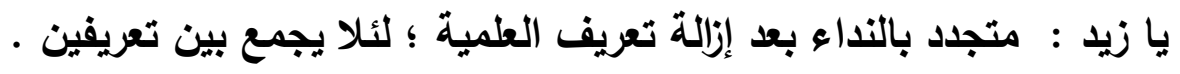
والصحيح أن تعريف العلمية مستدام كاستدامة تعريف الضمير واسم الإثـارة

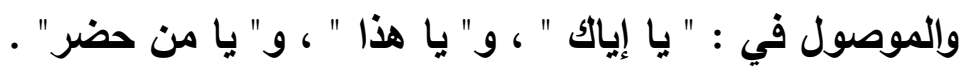

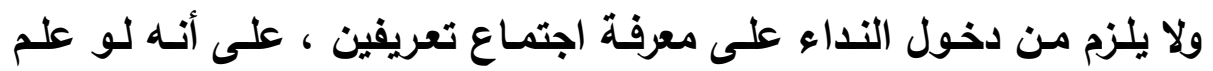

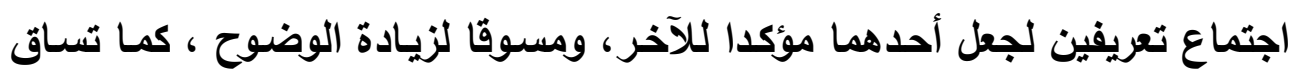
الصفة لذلك ، ويكون ذلك نظير اجتماع دليلي المبالغة في : " علّامـة " و" دَوّاريّي"

\section{وصحح ابن يعيش قول المبرد . (؛)}

(1) انظر : اللمحة في شرح الملحة / / צץ 1 مع حاثية (0) ، وأوضح المسالك ؛ / ب ا مـع

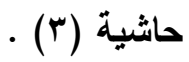

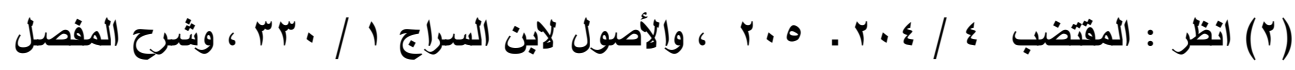

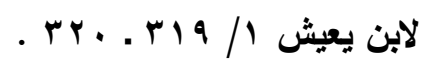

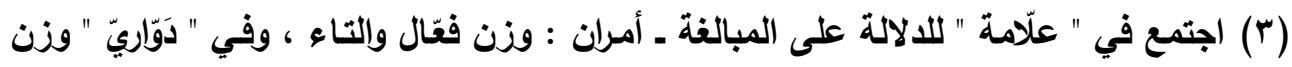

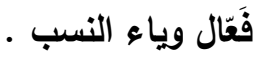

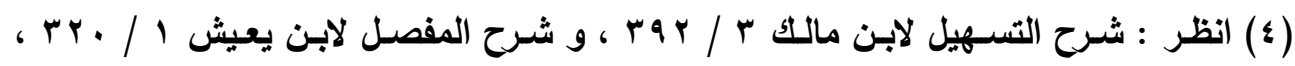

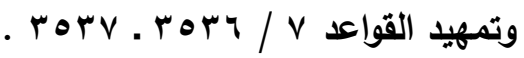


وهذا النوع من أنواع المنادى يبنى على مـا يرفع بـه ، في محل نصب . كما

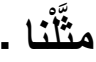
وقال ابن يعيش : " وقد ذهب قوم إلى أنه بين المعرب والمبني ، والمذهبُ

الأولُ ". (')

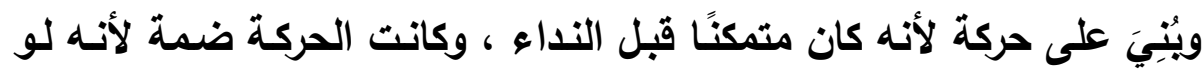

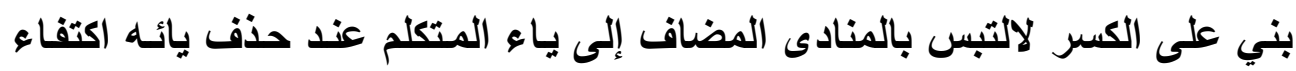

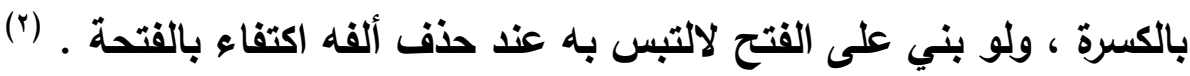

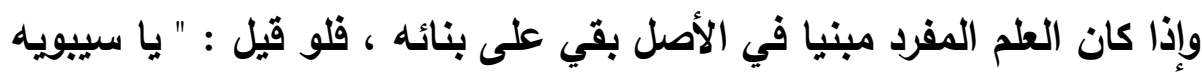

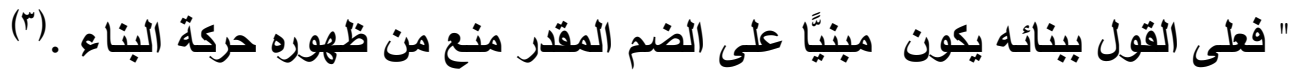

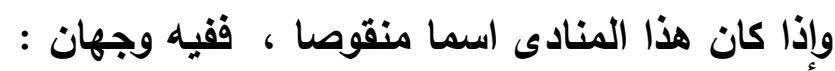

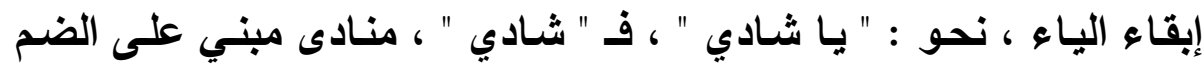
المقدر على الياء.

ويجوز " يا شادِ " ، بتقدير الضم على الياء المحذوفة .

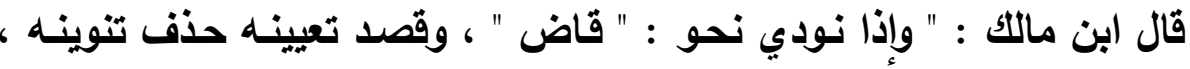

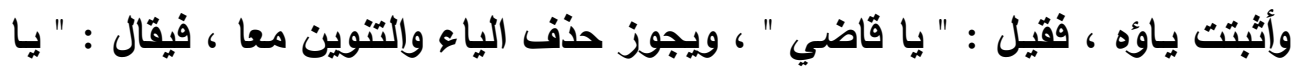

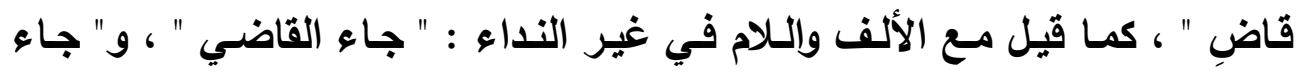
القاضِ "، والأول مذهب الظليل ، والثثاني مذهب يـونس ، وقوى مـذهب سييويه

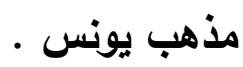

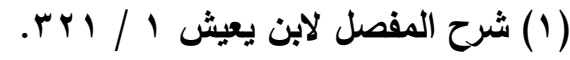

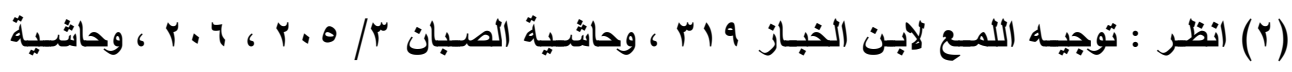

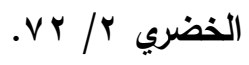

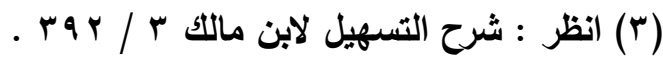


وإن كان المنقوص ذا أصل وإحد ، كاسم فاعل " أرى " ، رُرَّت الياء بإجماع ،

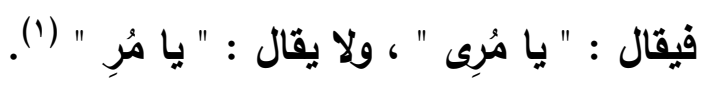

\section{الإقابل}

ويقابل المفرد هنا المضاف والثبيه به .

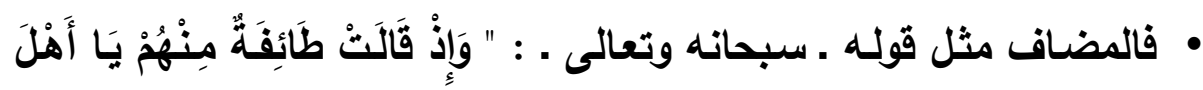

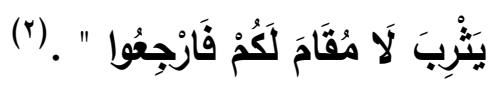

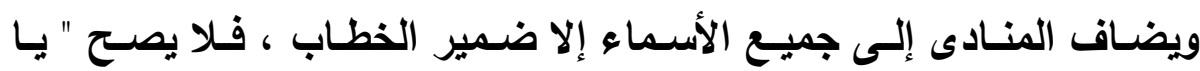

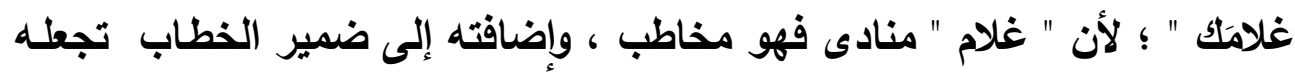

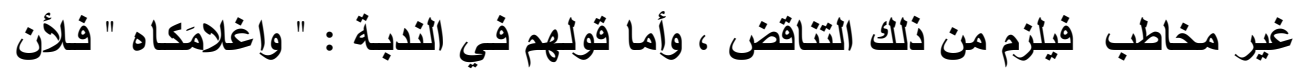
المندوب غير مخاطب ، بل متفجع عليه .

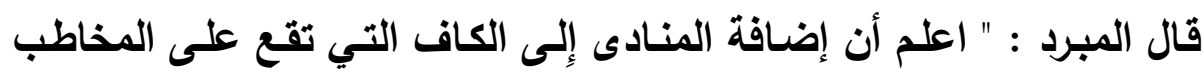

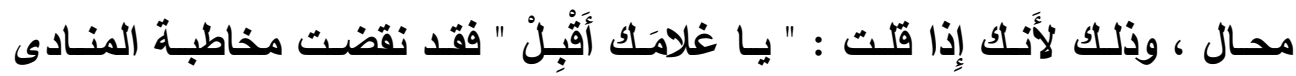
بمخاطبتك الكافَ .

فأما في الندبة فيجوز يا غلامكك ويا أخاك لأَن المندوب غير مخاطب وإنما هو

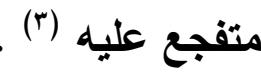
وفي المضاف إلى ياء المتكلم إذا نودي مثل : " يا غلامي " ست لغات ، فإذاذا

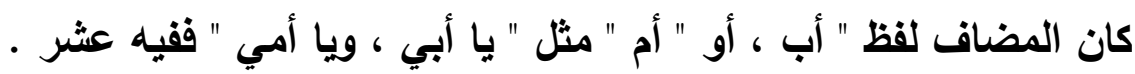

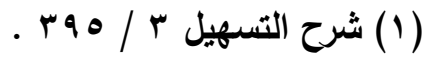

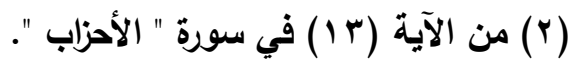

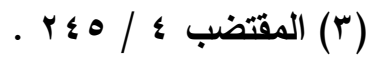


فإن كان مضافًا إلى مضاف إليها مثل " يـا غلام غلامس " لم يجز فيه إلا

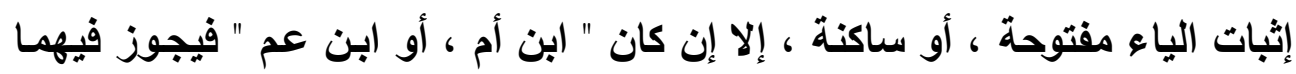

أريع لغات . (1)

ويشمل المضاف هنا مـا أقحمت التلام بينه ويبين المضاف إليهه ، كقول سـد ابن مالك :

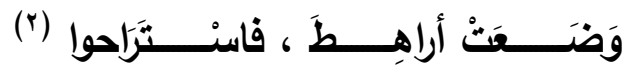

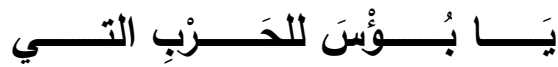

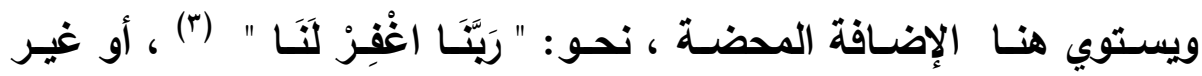
محضة ؛ نحو: يا حسن الوجه.

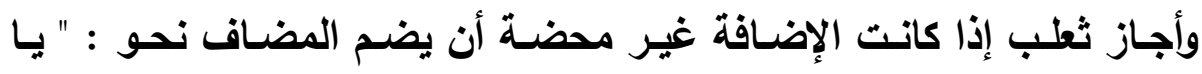

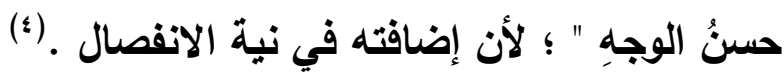

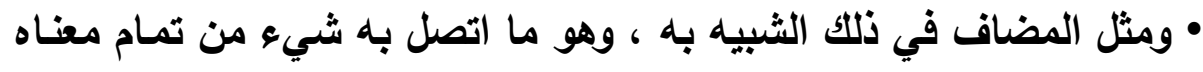
بعمل ، أو عطف قبل النداء .

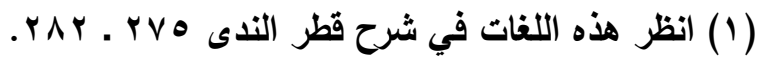

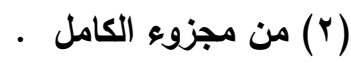

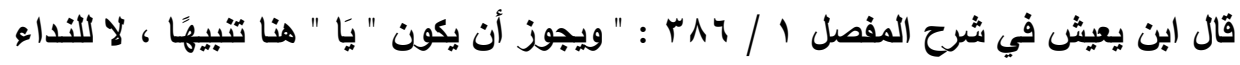

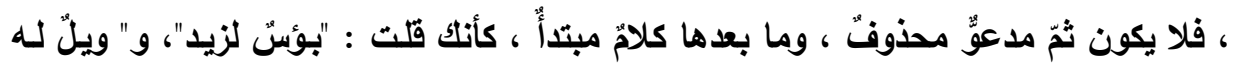

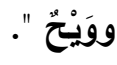

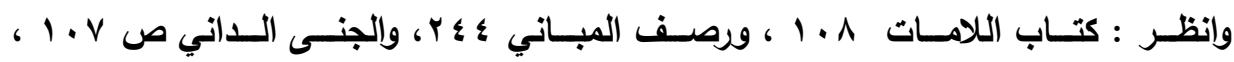

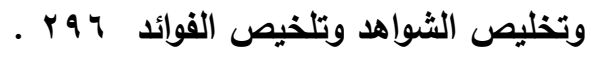

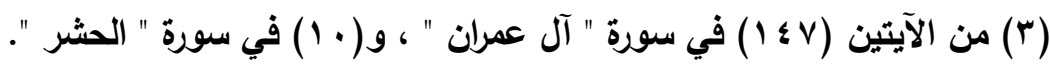

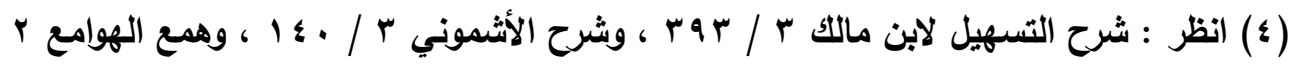
r rv/ 
والعمل إمـا رفع ، أو نصب ، أو جر بالحرف ـ كما سبق . في " لا " النافية

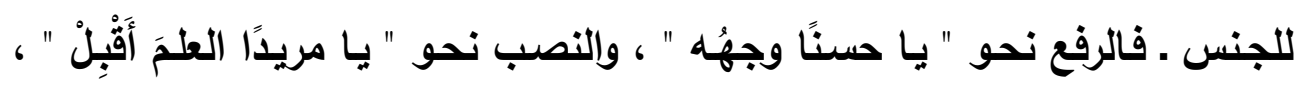

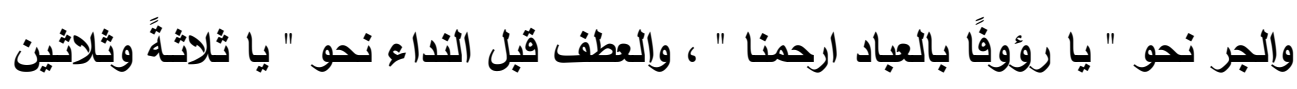

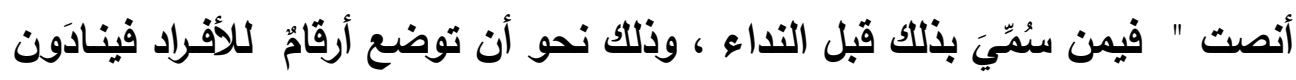

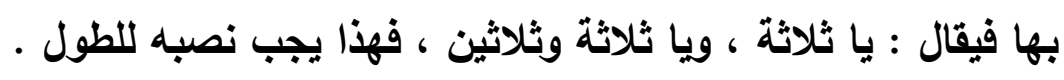

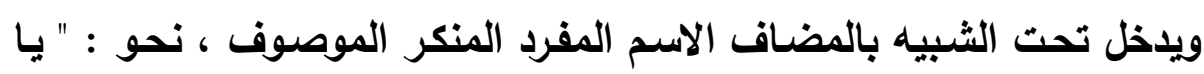

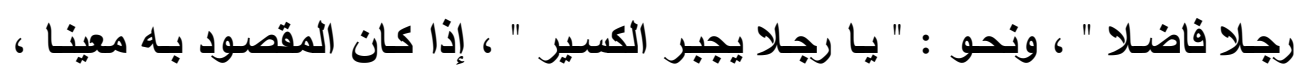

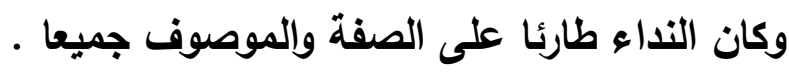
وكذلك الوصف المقترن بجملة ، مثل " يا رجلا كريما أقبل " .

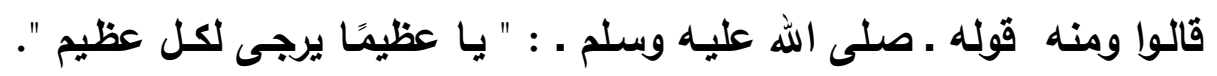

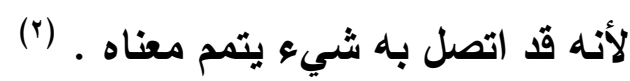

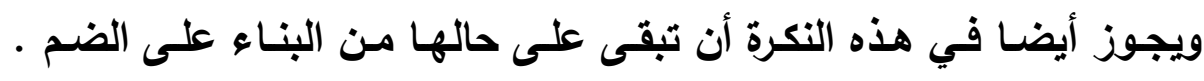

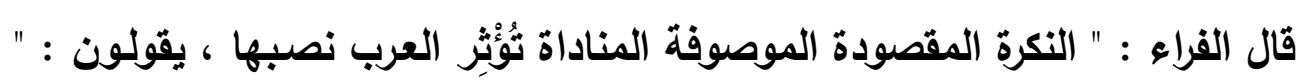

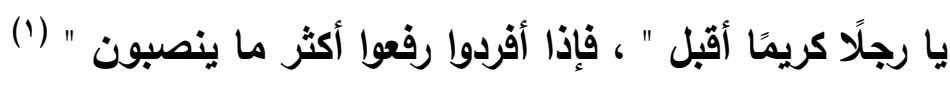

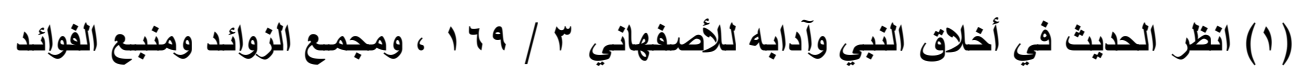

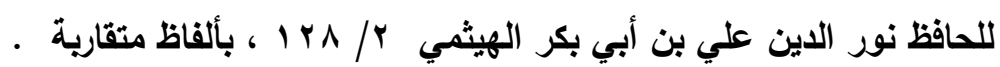

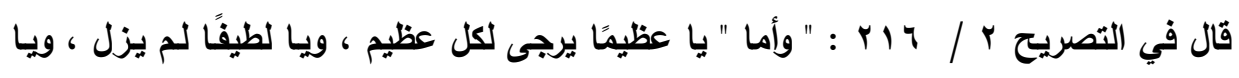

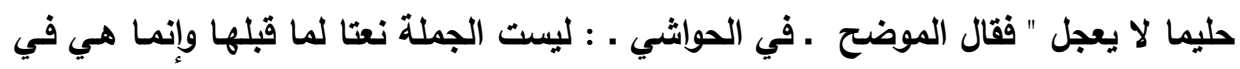

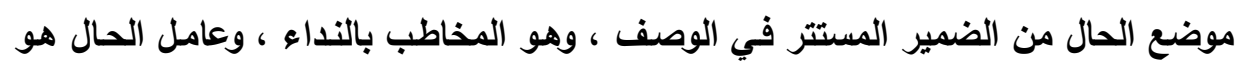

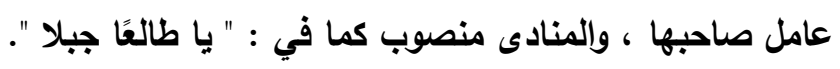

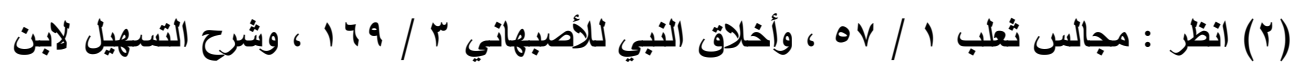

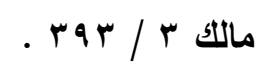


ووجه شبهه بالمضاف سبق ذكره في " لا "النافية للجنس .

\section{المغرد في باب المدد}

المقصود بالمفرد في هذا الباب العدد من واحد إلى عشرة .

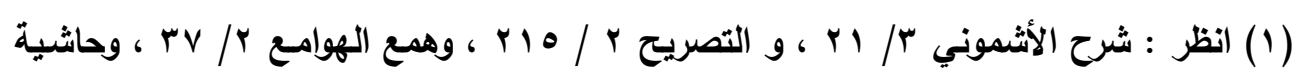

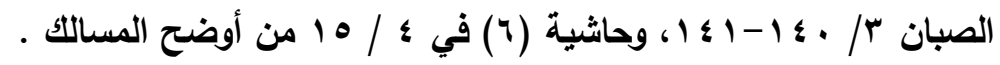


وينــرج تحتـه ألفـاظ العقود ، والمائـة ، والألـف ومضــاعفاتهما ، وإن كاتـت تختلف في بعض الأحكام .

ويقابله هنا العدد المركب ، والمعطوف .

أولا : الافرد من واحد إلى عشّرة .

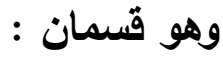

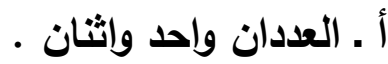

ب ـ الأعداد من ثلاثة إلى عثرة .

أ ـ فالواحد والاثنان لا مُمَيِّز لهما ؛ لأن اللقظ يدل على العدد والمعدود معا .

قال " أبو حيان " : لا يقال : " واحد رجل ، ولا : اثنا رجل ، ولا : واحد رجال ، ولا : اثتـان رجـال " ، لا بمفرد ولا بجمع ، استغنوا عن ذلك بـالنص على المفرد والمثنى،قالوا : " رجل " ؛ لأنه يال على أنه واحد ، وقالوا : " رجلان " ؛ لأنـه يدل على التثية فكان ذلك أخصر وأجود " (1).

وفي حالة تعريفهما بـ " ال " فإنها تلخل على العدد مباشرة ، فيقال : الواحد ،

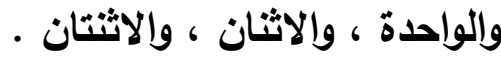

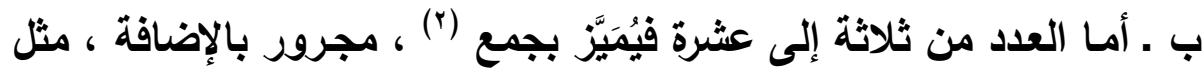

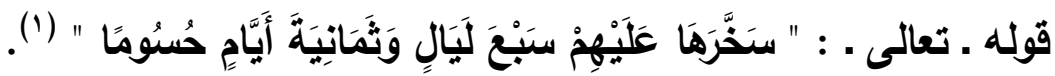
(r) قال الفارسي : " ... الأصل في الأسماء التي تبين العدد أن تكون مفردة ، وذلك أن المعدود

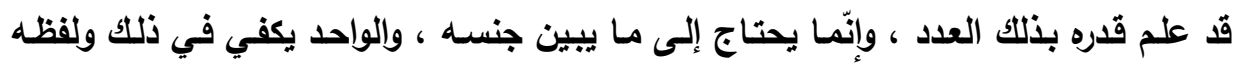

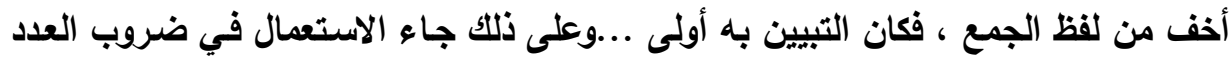


فإذا وقعت المائة بعده أفردت ولم تجمع . (r) وهذا العدد يكون بالتـاء مـع المـكر ، ودونها مـع المؤنث ، فيقال : " ثلاثذة

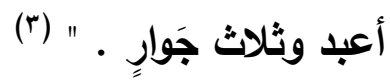

والأي يعتد به في التذكير والتأنيث هو المفرد لا الجمع ؛ فلألك يقال : " ثلاثة

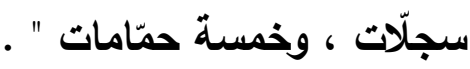
قال ابن عصفور : " تاء الثلاثة وأخواتها تسفط لتأنيث واحد مفسرها ، لا لتأنيثه نفسـه ، إن كان جمعا ، ولتأنيثـه نفسـه دون تعرّض لواحد ، إن كان اسـ

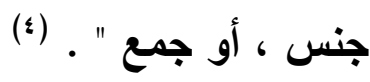
وخالف في ذلك الكسائي والبغداديون ، فإنهم يقولون : مررت بثلاث حمّامـات ، وأيت ثلاث سجلّات وإن كان الواحد مذكرا (•) ، ولا يعتد بتأنيث المفرد إذا كان

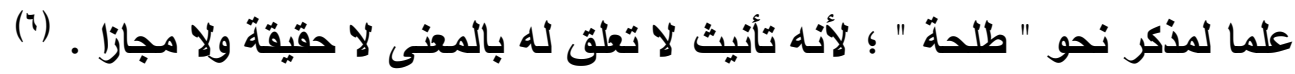

إلا ما كان من الثلاثة إلى العشرة ، فإنه يبين بجموع القلـة ؛ لأنها تثببه الآحاد ، من جهة

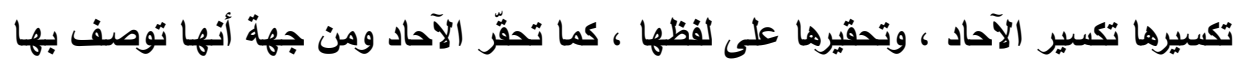

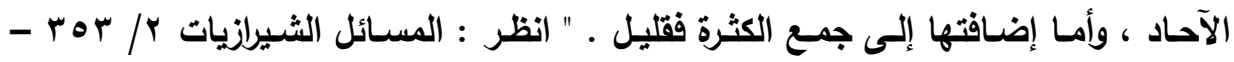

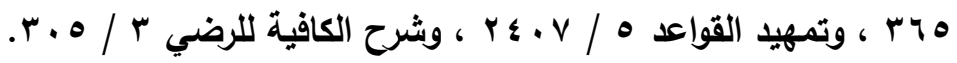

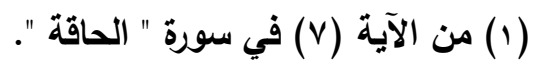

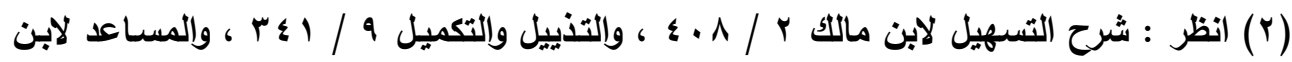

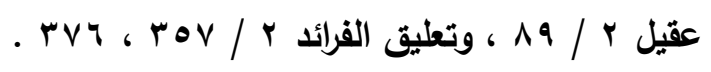

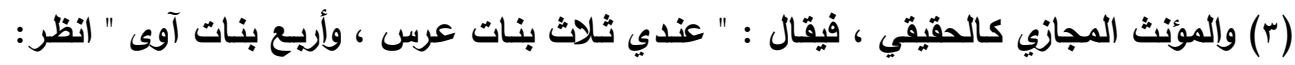

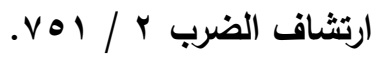

$$
\begin{aligned}
& \text { (اء) انظر : المقرب لابن عصفور / / ؟ • بـ. }
\end{aligned}
$$

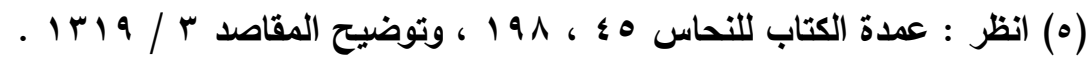

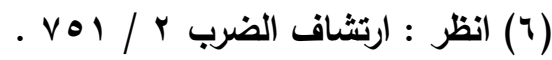


وإذا أريد مجرد العدد فإنـه يكون بالتاء سـاكنة ، ويعض النحويين يقول إنها

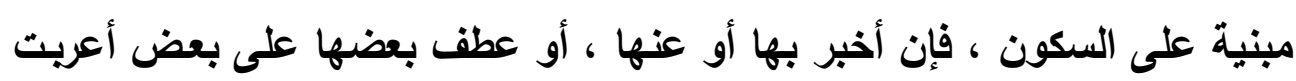

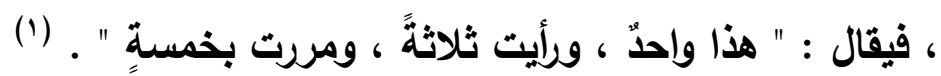

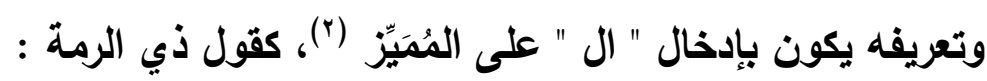

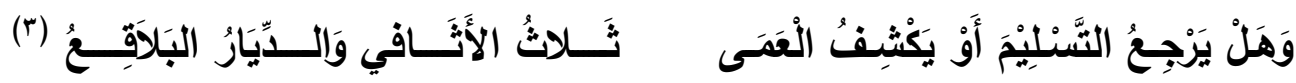
ثانيا : ألفاظ العقود

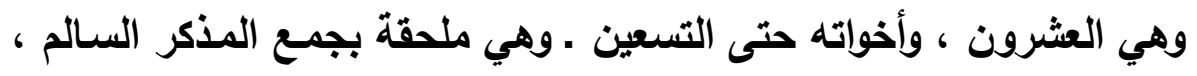

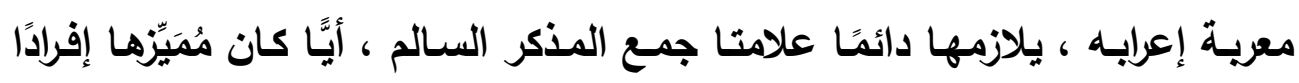

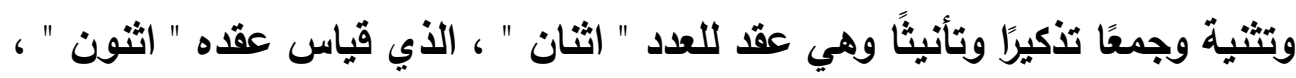

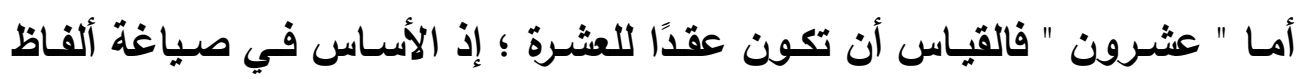

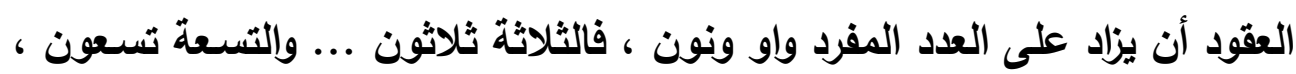

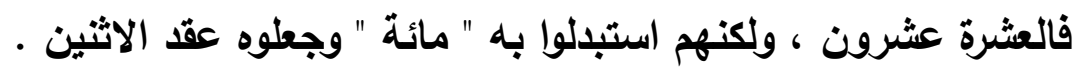

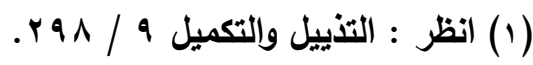

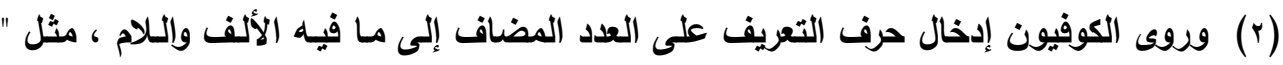

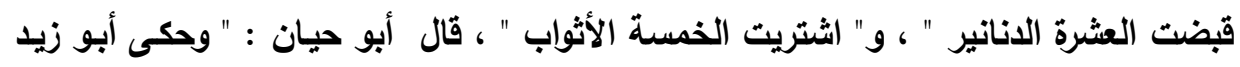

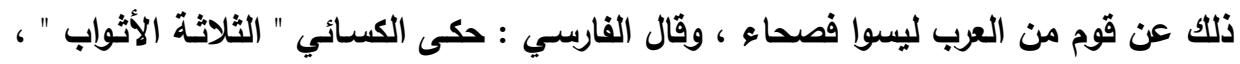

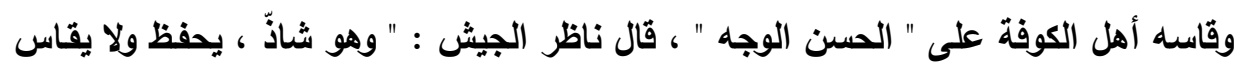

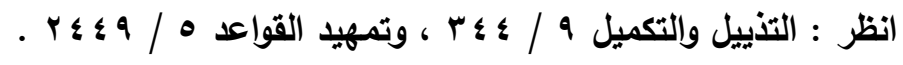

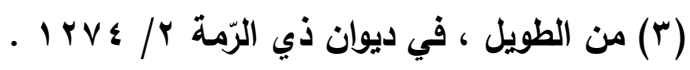

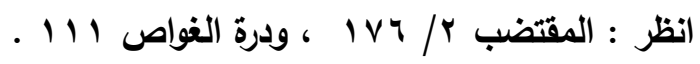




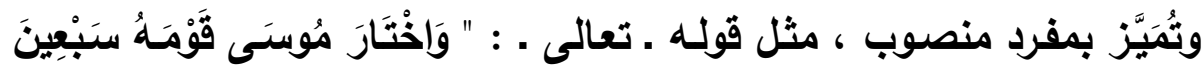

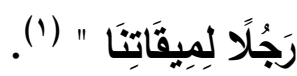

وقد تضـاف هذه الألفـاظ إلى غير تمييزهـا ، قـال الخضري : " العدد مطلقا

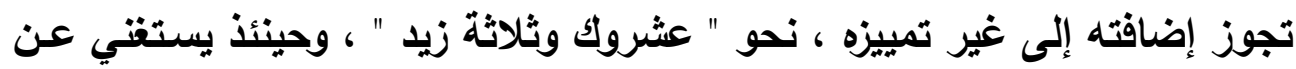

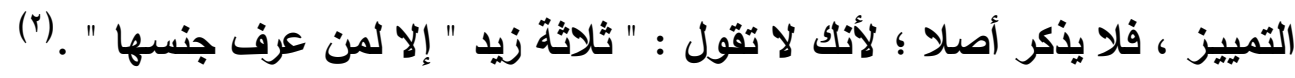

وتحذف النون من ألفـاظ العقود عند الإضـافة ، فتقول : " هذه عشروك ،

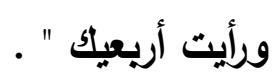

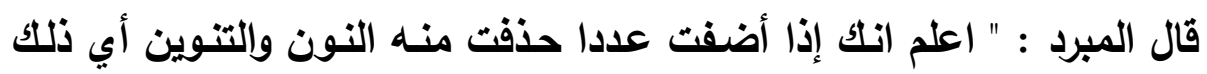

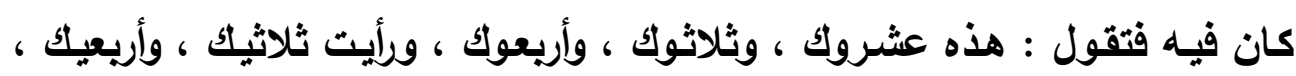

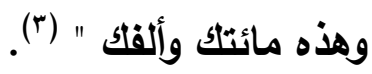

وتعريفهـا يكـون بإدخـال " ال " علــ العـدد ، فيقـال : " العشـرون رجـلا ،

(צ) " والأريعون امرأة

ثالثا : المائة ، والألف ، ومضاعفاتهما

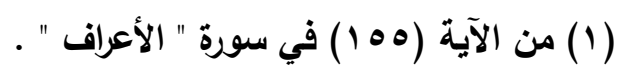

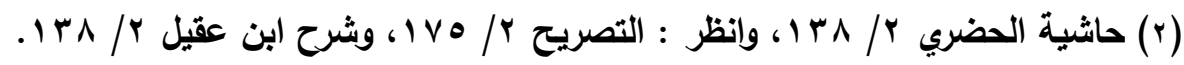

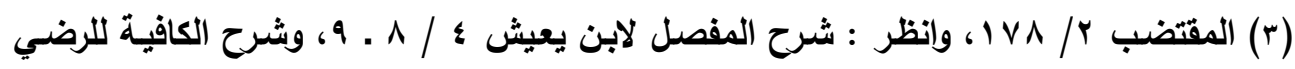

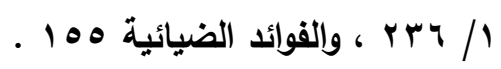

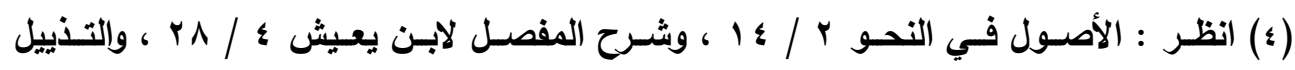
والتكميل 9 / 9 /. r. 


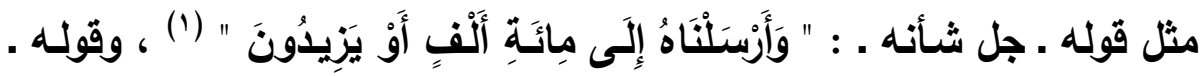

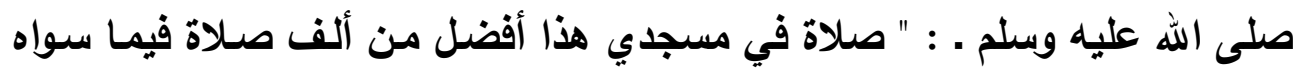

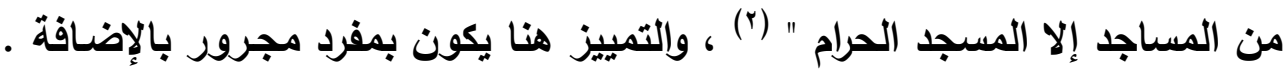

وحُكِيَ عن " ابن كيسـان " جواز تنوين المائسة ، والألف ونصب الميز ،

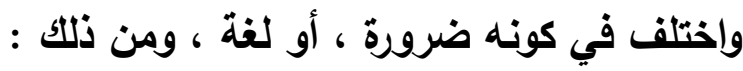

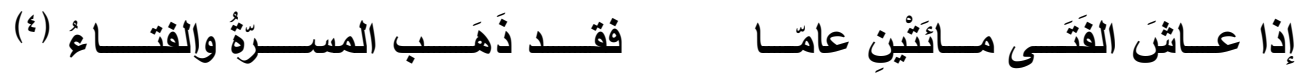
قال ابن سيده : اختلف النحويون في تعريف العدد ، فقال البصريون : مـا

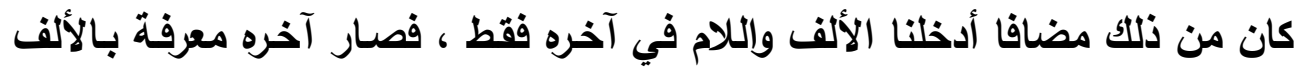

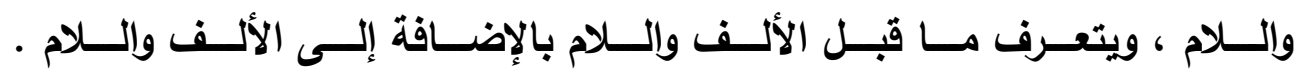

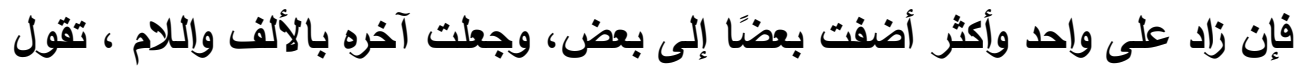

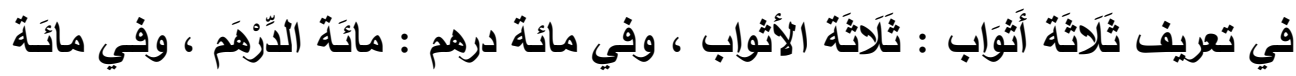

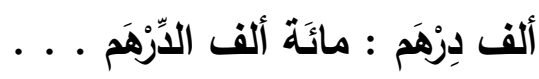

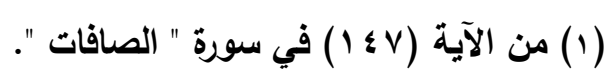

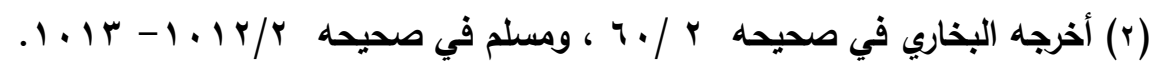

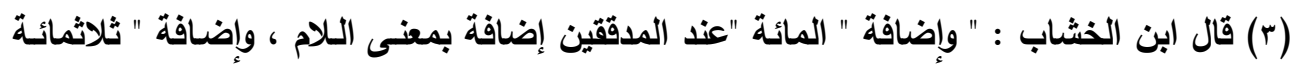

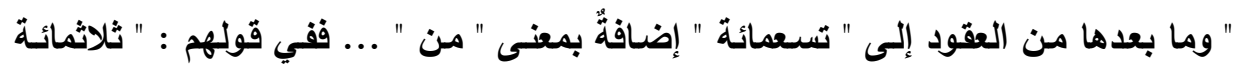

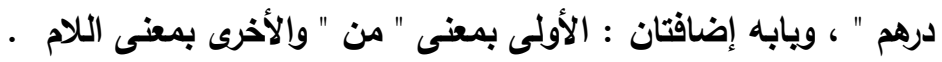

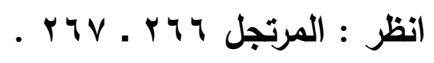

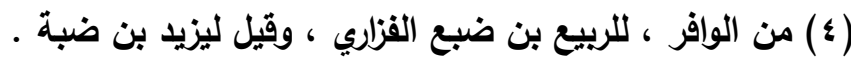

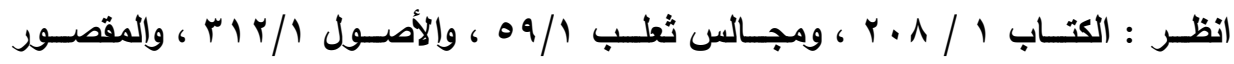

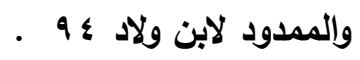


وأجـاز الكوفيـون إدخال الألف والتلام على الأول والثاني ، وشبهوا ذلكت بـ "

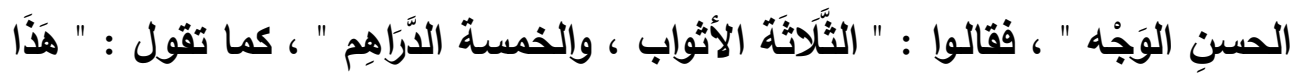

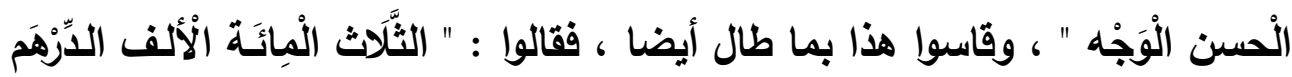

وقال ابن مالك : " دخول حرف التعريف على العدد المفرد غيرَ مفسَّرٍ ، أو

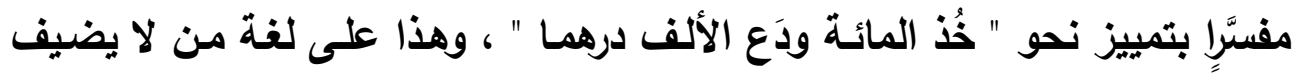
عومل فيهما ذو الألف والللام معاملة المنون ، ذكر ذلك ابن كيسان ، وعليه ورد

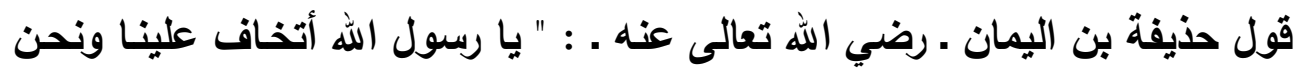

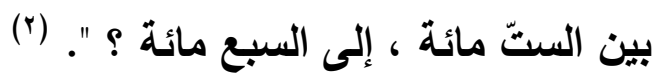

\section{الإقابل}

والمقابل هنا هو العدد المركب ، والعدد المعطوف .

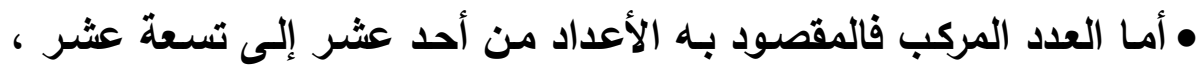

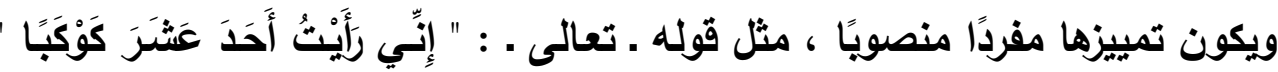

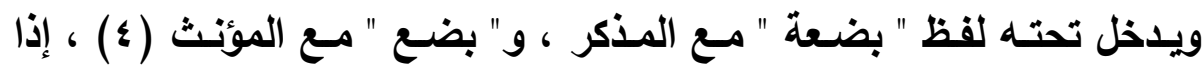

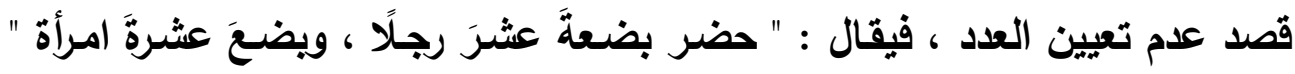

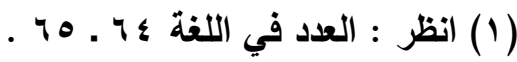

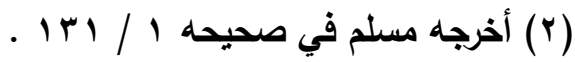

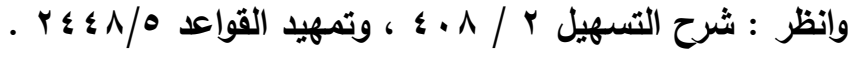

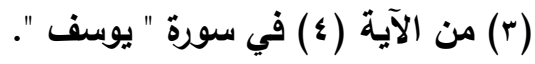

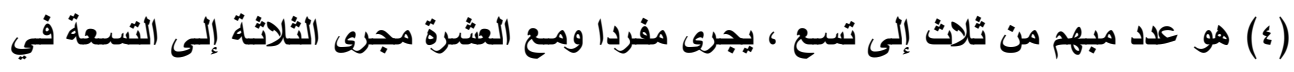

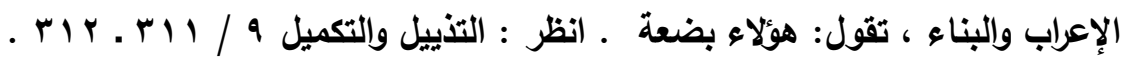


بالتاء مـع المذكر ومن دونها مـع المؤنتث ، حكمه في ذلك حكم العدد المفرد من ثثلاثة إلى عشرة ، ويأخذ حكم المركب في البناء على فتح الجزأين ـ كما سبق . . ولا يذكر البضع مع عدد آخر سوى العشرة وألفاظ العقود ـ كما سيأتي . فـلا يقال بضع مائة ، ولا ألف . قال أبو حيان : " وقال أبو عمرو بن تقى : البضع ليس نصا في عدد بعينها إنما هو من الثلاثة إلى التسعة ، وهو اسـ جمـع كالتفر، ويستعمل وحده ، كقولـه

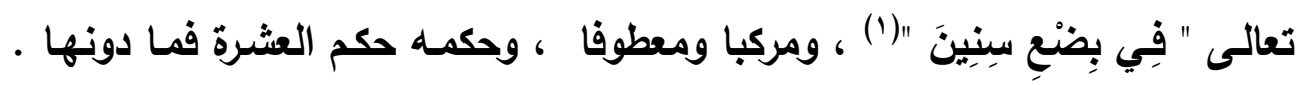

وأصلـ العدد المركب أن يكون بـالواو ، فـ " خمسـة عشـر " أصـلها خمسـة

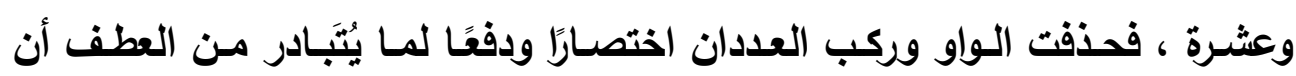

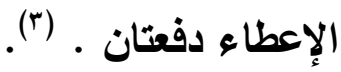
والعدد المركب مبنـي على فتح جزأيسه ؛ لأنه بالتركيب نُزِّل الجزء الثاني من الأول منزلة بعض الكلمة من بعض كما في العدد ويعض المركبات الأخرى كتركيب "

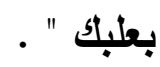

وإنما لم يجعل العدد المركب كلمة واحدة ويجرِ الإعراب عليها كما في المركب

المزجي أن امتزاج الكلمتين في المركب المزجي أثد ، أما في العدد فليس كذلك (ء)

$$
\begin{aligned}
& \text { (1) من الآية (ع) في سورة " الروم " . }
\end{aligned}
$$

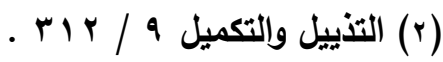

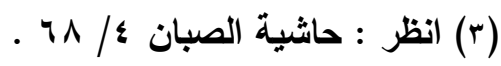

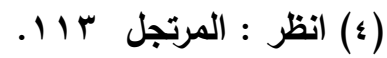


وقد يأتي الاسم بعد العدد المركب جمعًا منصويًا ، مثل " أقبل خمسةً عشرَ

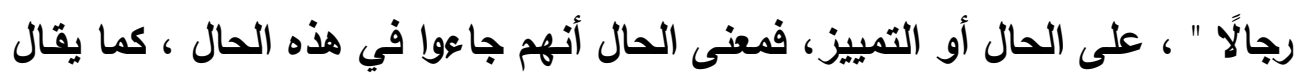

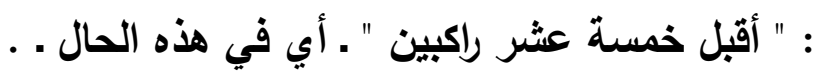

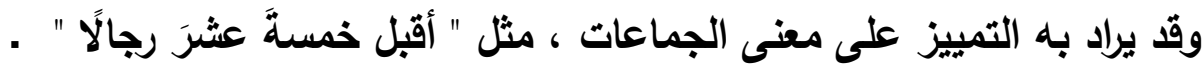
أي : أقبل خمس عشرة جماعة ، كل جماعة هي رجال .

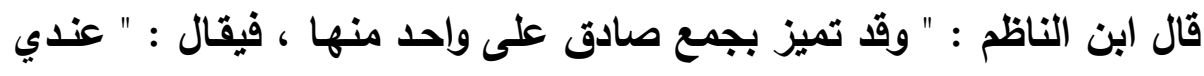

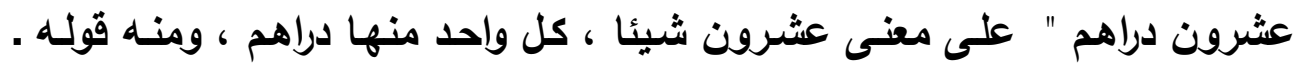

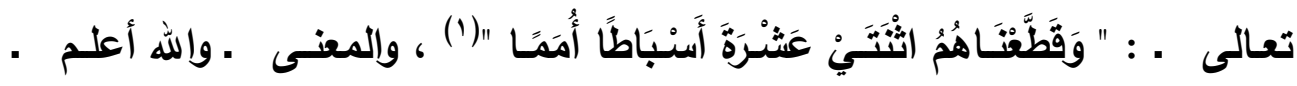

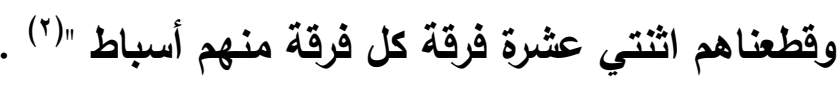

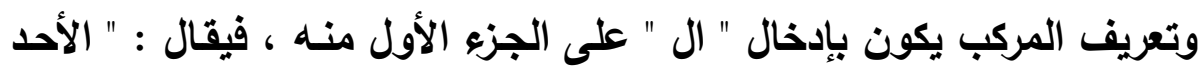

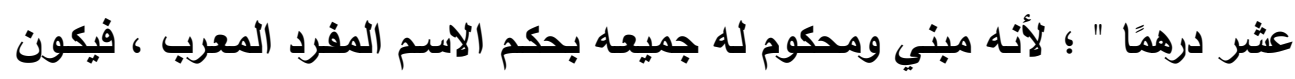

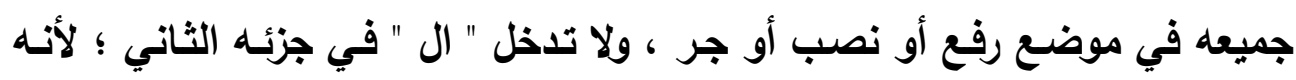

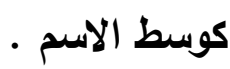

ومذهب الأخفش والكوفيين جواز تعريف الاسمين المركبين ، وحكاه الأخفش

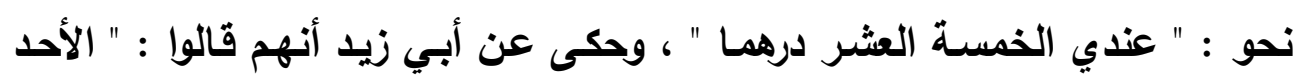

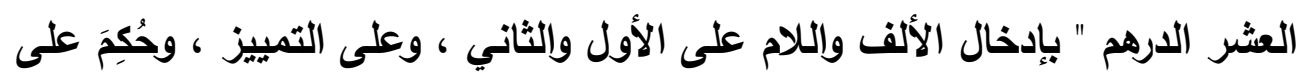

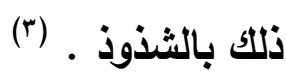

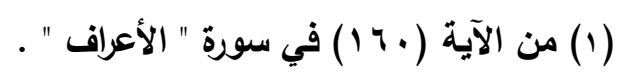

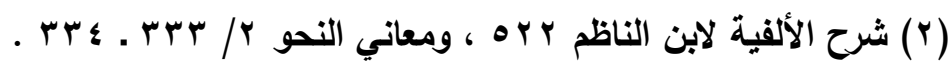

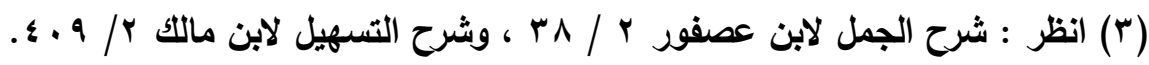


قال المبرد : " اعلم أن قومًَا يقولكون : " أخذت الثلاثـة الدراهم يـا فتى " ،

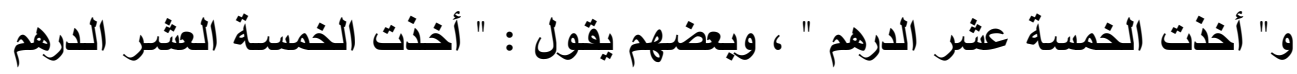
و" أخذت العشرين الارهم التي تعرف " ، وهذا كله خطأ فاحش .

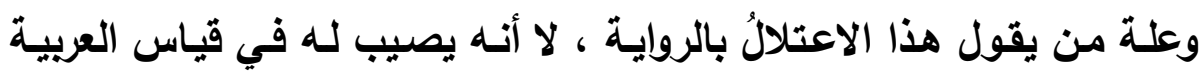

نظيرًا " (1)

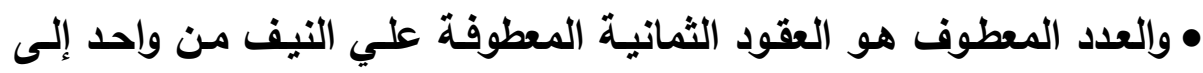
تسعة ، حين يقال : واحد وعشرون إلى تسعة وعشرين ... وهكذا مـع باقي العقود

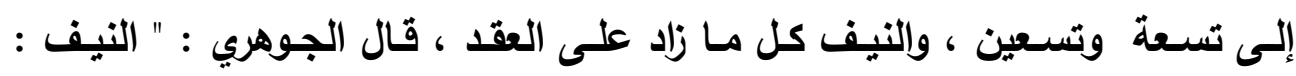

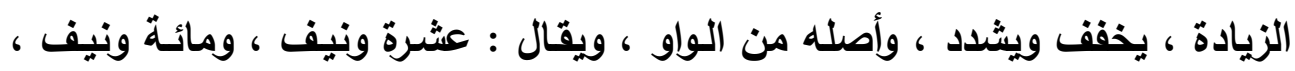

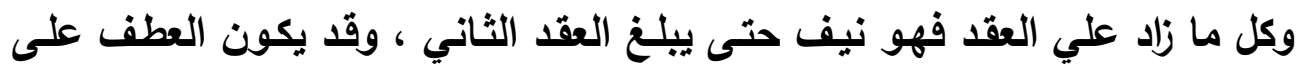

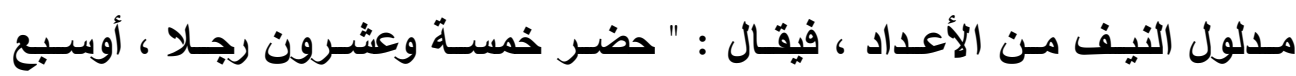

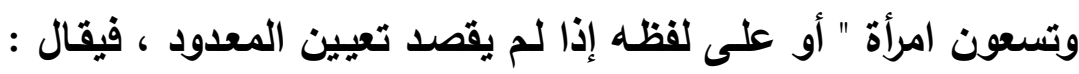
حضر نيف وعشرون رجلا ، أونيف وتسعون امرأة " . ويلزم لفظ النيف صورة المذكر أيَّا كان المعدود تذكيرًا أو تأنيثًا .

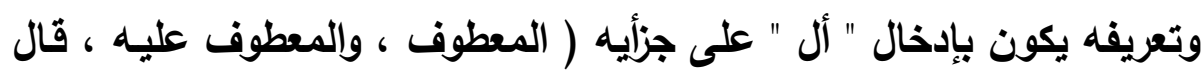

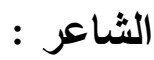

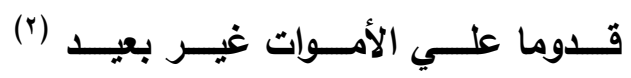
إذا الخمسنَ وإلخمسين جـاوزت فارتقب

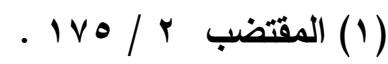
(ץ) (؟) من الطويل ، ولم أقق على قائله : 
وروى بعضـهم أيضـا دخولـه عليهمـا وعلى التمييز ، ويعضهم دخولهـا على المعطوف عليه دون المعطوف . بهوف

قـال في الارتثـاف : " وأجـاز قوم دخـول " أل "على تمييز العقد نحـو : " العشرين الدرهم " ، والمعطوف تدخل " أل" على المتعـاطقين ، " تقول : " الأحد والعشرون درهمًا " ، وأجاز قوم دخولها عليهما وعلى التمييز ، وقوم إدخالها على ، ولى المعطوف عليه وتركها من المعطوف نحو : " الأحد وعشرون " ، وجوز ذلك شيخنا الأستاذ أبو الحسن الأبذي . " (1)

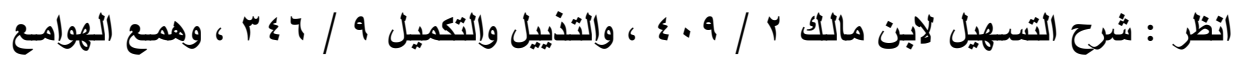
- r०q/r

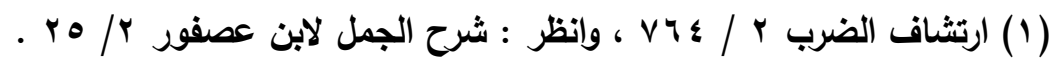




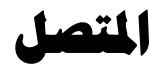

\section{اـ المتمل في باب الضمير}

الضمير المتصل هو الذي لا يستقلّ بنفسـه .أي لا ينفك عن كلمـة أخرى

(1) . يتصل بها (1)

وهذا الضمير لا يبتدأ بـه في أول الكلام ، وهو غير مستقل بنفسـه ، سواء

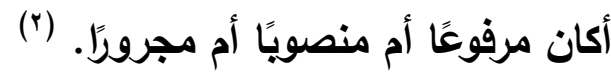

وهو تسعة ألفاظ :

أ ـ منها ما لا يقع إلا في موضع رفع ، وهو خمسة ألقاظ ، هي :

ا ـ تاء الفاعل . مضمومة للمتكلم ، مفتوحة للمخاطب ، مكسورة للمخاطبة ،

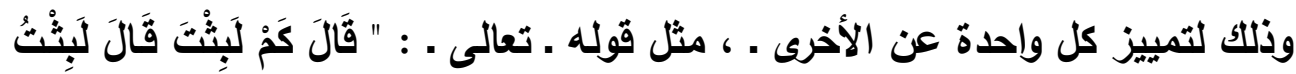

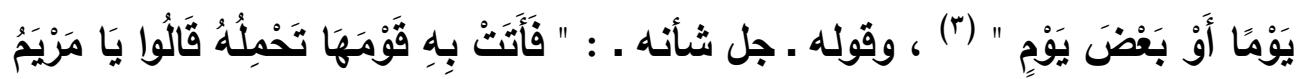

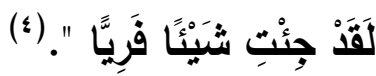

ويضاف لهذه التاء ـ وكذلك كاف الضمير وهاؤه ـ مع جمع الأكور العقلاء ميم

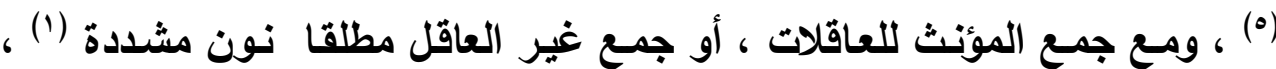

ومع المثنى مذكرا أو مؤنثا " ما " . .

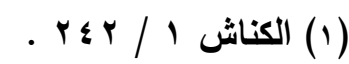

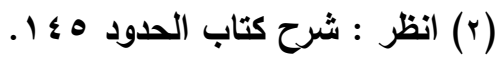

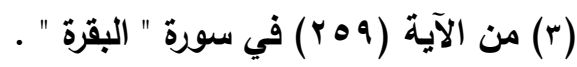

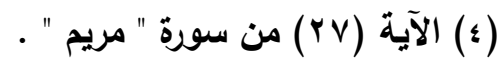

(•) الأصل في جمع المذكر أن يقال : " مررت بكمو " ، وهذا غلامكمو " فالميم والثواو للجمع ، 
ومن العلماء من يجعل الضمير ومـا يلحقه من العلامـات كلمـة وإحدة بإعراب واحد ، ومنهم من يرى أن الضمير هو التاء ، والكاف ، والثهاء ، وأن هذه الملحقات

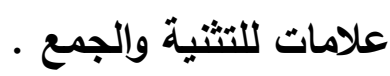
واختلف القول أيضا هل " ما " كلها علامة التثنية " ، أو الالف علامة التثية ، والميم حرف عماد ؛ لاعتماد المتكلم والسامع عليها في التفرقة بين ضمير التثنية وضميز الواحدة . قال السيوطي : " وخص المتكلم بالضم لأنَه أول عن المخاطب فكان حظـه من الحركات الحركة الأولى ، وقيل : لأَنه إذا أخبر لا يكون إلا واحدًا ، وإذا خاطب

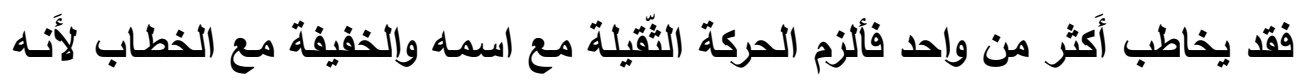
أكثر ويعطف بعضهه على بعض ، وكسروا المؤتث لأن الكسرة من علامسة التأنيث

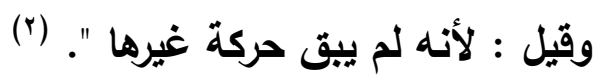

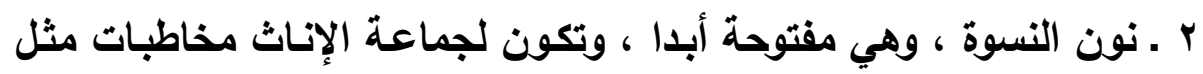

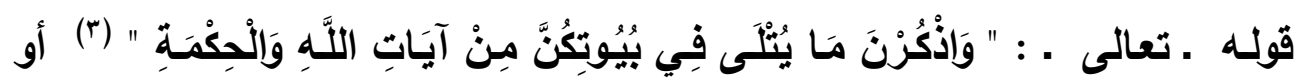

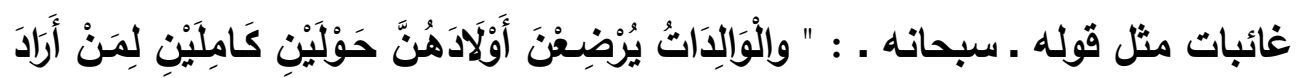

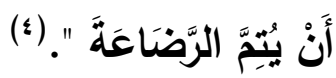

وحذف الواو وتسكين الميم يكون للتخفيف .

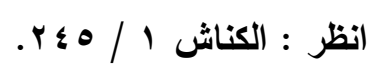

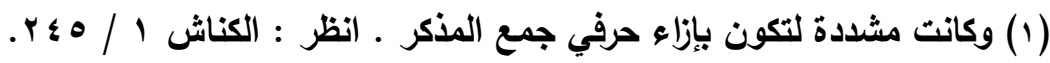

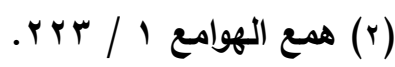

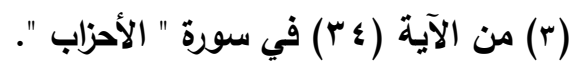

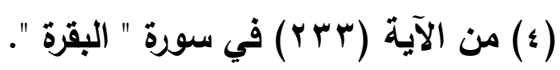


r ـ واو الجماعة ، وتكون لجماعة الذكور مخاطبين مثل قويله تعالى . : " يَا

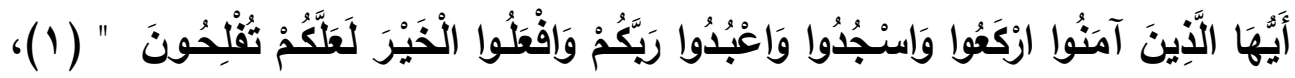

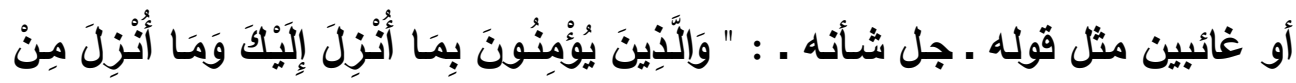

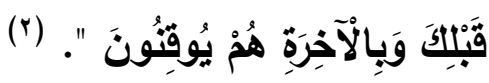

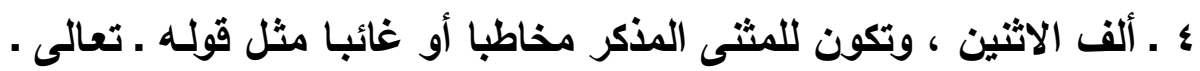

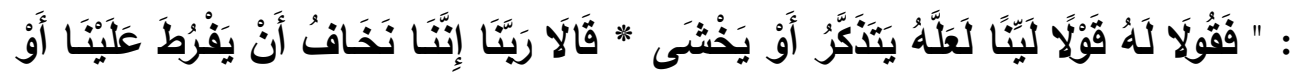

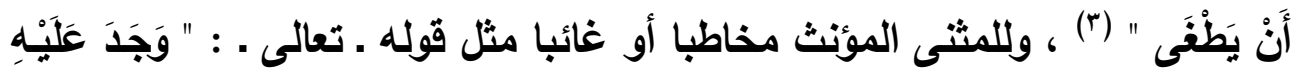

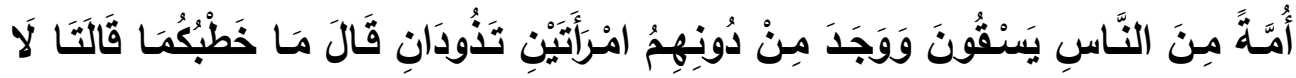

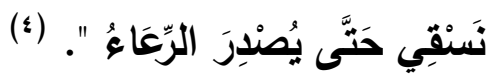

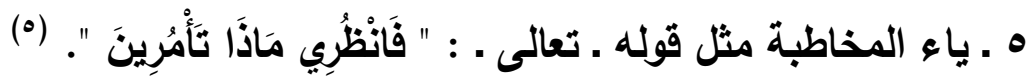

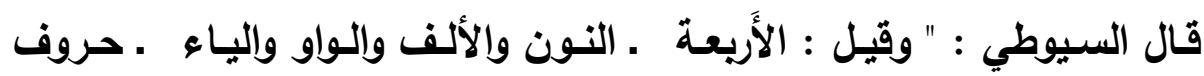

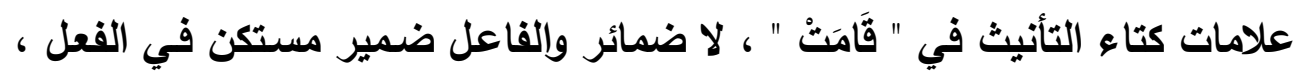
وعليه المازني ، ووافقه الأخفش في الياء .

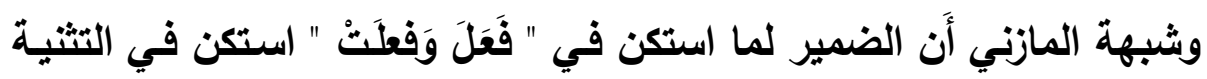

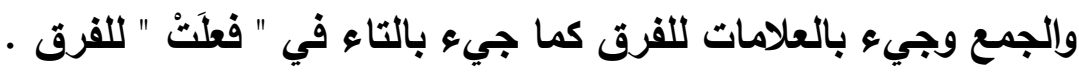

$$
\begin{aligned}
& \text { (1) الآية (VV) من سورة " الحج ". }
\end{aligned}
$$

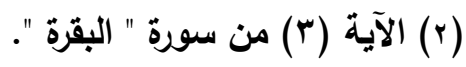

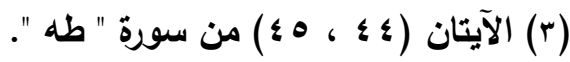

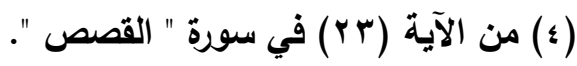

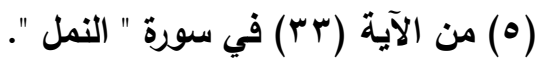




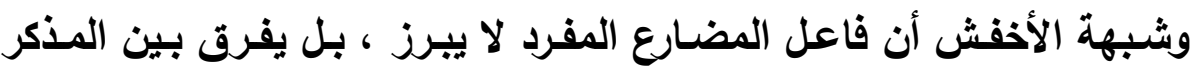

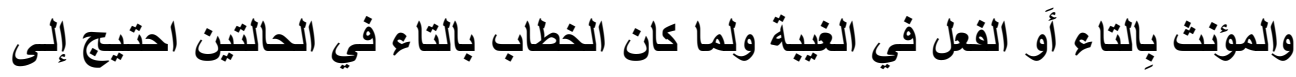
الفرق فجعلت الياء علامة للمؤنث .

ورد بأَنها لو كانت حروفا لسكنت النون ، ولم يسكن آخر الفعل لها ، ولثبتت

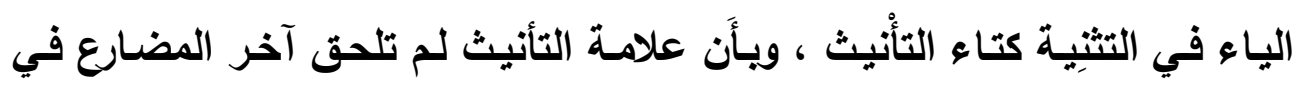
موضع " (1) ب ـ ومنها ما يقع في موضع نصب أو جر ، وهو ثلاثة :

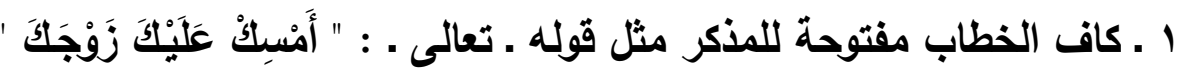

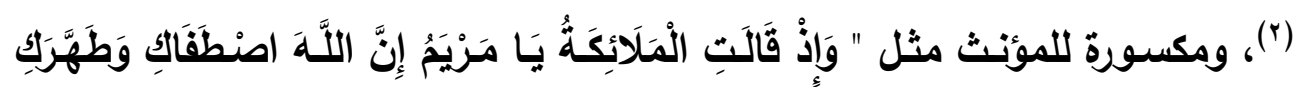

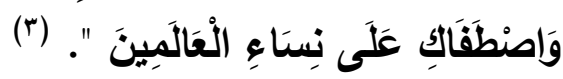

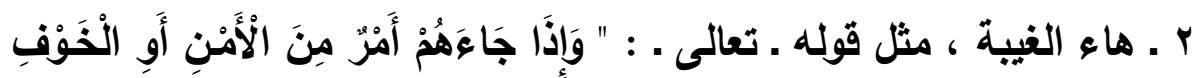

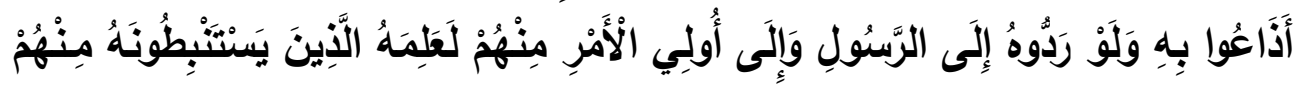
(घ)."

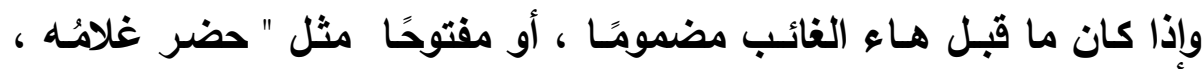

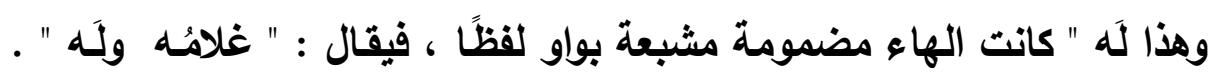

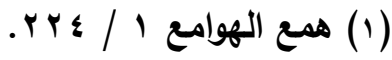

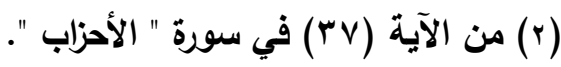

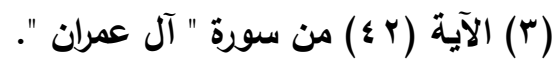

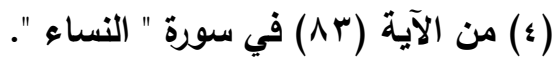


فإِذا كان قبلها كسرة ، أو ياء ساكنة كُسرَرَتْ مثُل " بـه ، وفيهه ، وعليه " ،

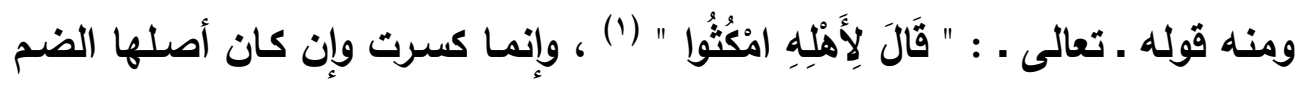

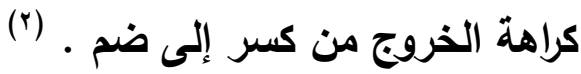

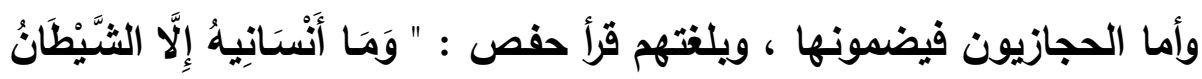

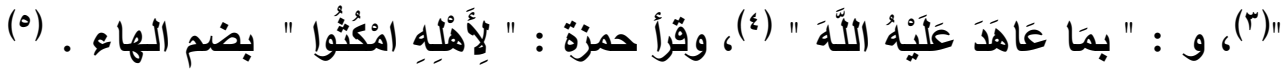

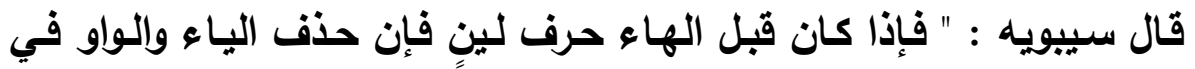
الوصل أحسن ؛ لأن الهاء من مخرج الألف ، والألف تثبه الياء والكواو ، تثبههما

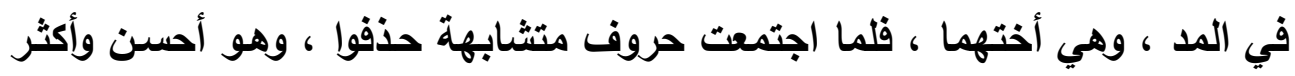

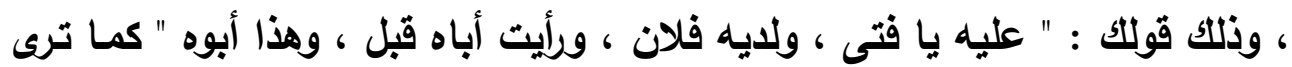

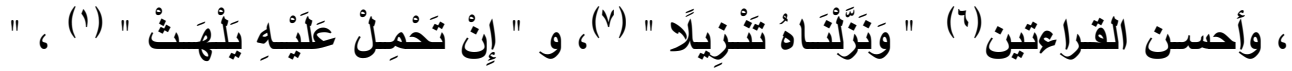

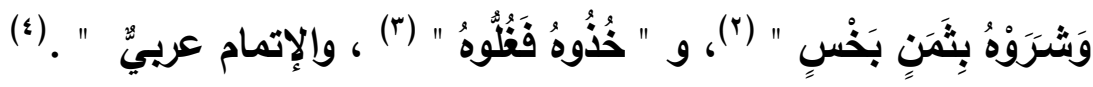

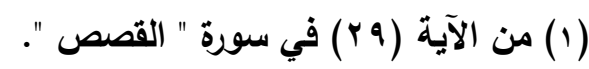

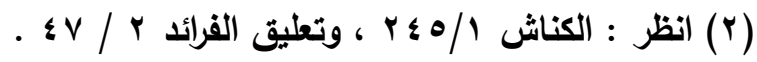

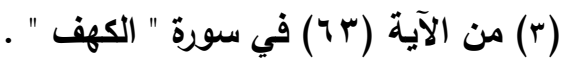

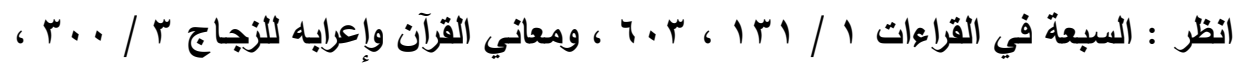

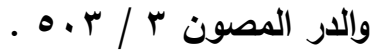

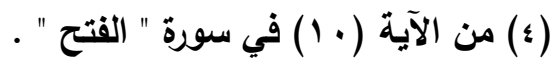

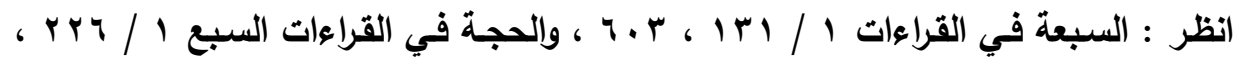

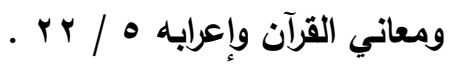

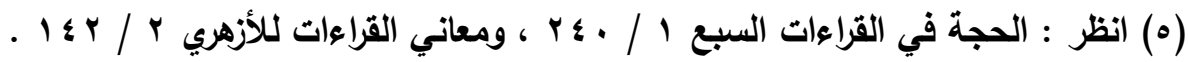

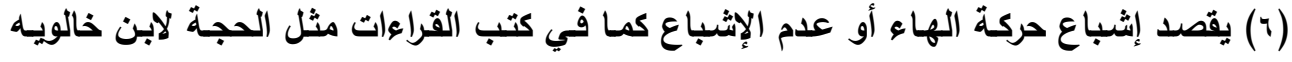

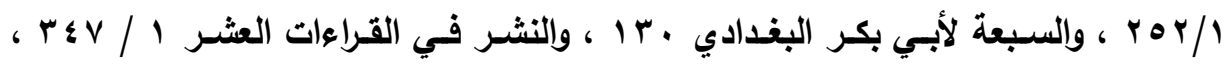

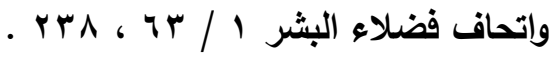

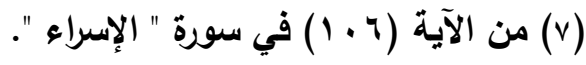


وإذا تحرك ما قبل هذه الهاء نحو : لله ويه ، فلا يجوز عند البصريين حذف

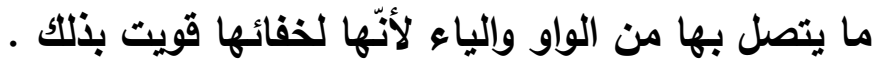
قال في الكناش : " وقث حذفت هذه الصلة في الثُّر ـ " (•) وقال السيوطي : " إذ وقعت الهاء بعد سـاكن فالأفصح اختلاسـها سواء كان صحيحا نحو : " منه ، وعنه ، وأكرمه " ، أو حرف علة نحو : " فيه ، وعليه " ، هذا رأْي المبرد ، وصححه ابن مالك ، وخص سيبويه ذلك بحرف العلة ، وقال : الأفصح بعد غيره الإثباع ، وإختاره أبو حيان .

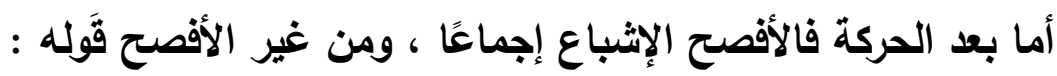

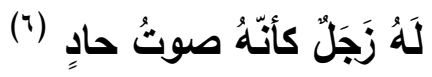

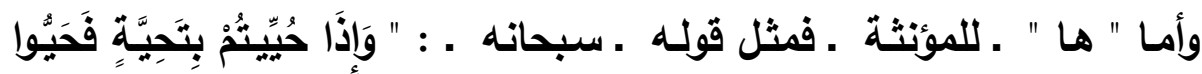
بأَحْسَنَ مِنْهَا أَوْ رُدُوُوهَا ".

$$
\begin{aligned}
& \text { (1) من الآية (1VY) في سورة " الأعراف ". }
\end{aligned}
$$

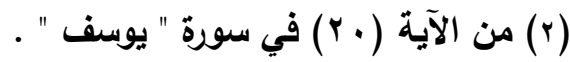

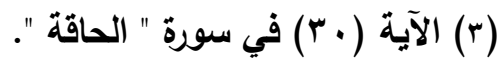

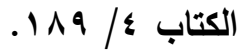

$$
\begin{aligned}
& \text { الكناش 1 / } 1 \text { / }
\end{aligned}
$$

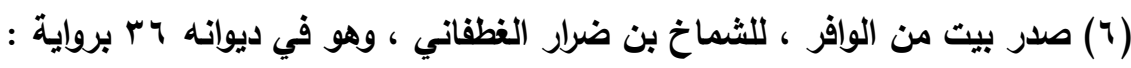

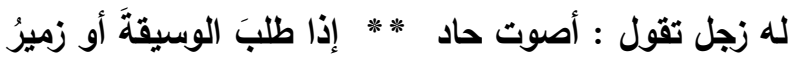
ونسبه الغندجانى إلى الربيع بن قطب الفزاري . ويستثهر بالبيت على اختلاس الضمة بعد هاء الضمير، وهو ضرورة عند الجمهور جائز عند بني عقيل ويني كلاب .

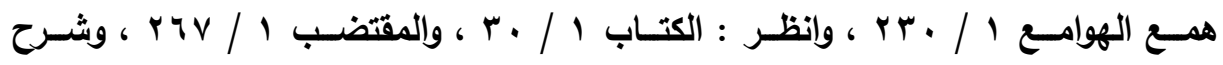

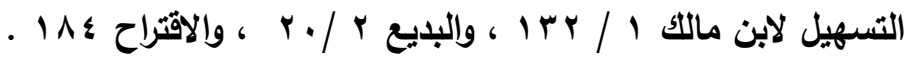


قال الدماميني : " حكى السيرافي الاتفاق على أن الضمير هو مجموع الهاء والألف ، وقيل : الألف زائدة مقوية لفتحة الهاء القارقة بين المذكر والمؤنث ". (ץ) وجاء في لغة طيّئ حذف هذه الألف ونقل حركة الضمير إلى ما قبله ، ومنه

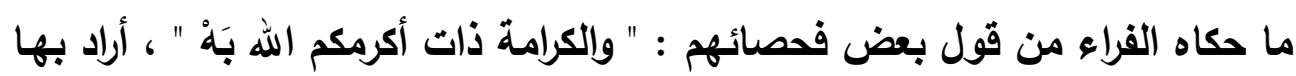

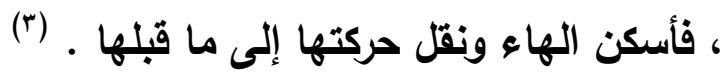

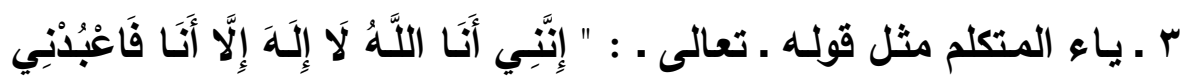

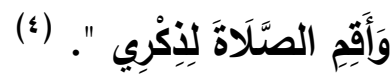
ج - ومنها مـا يقع مرفوعا ومنصويا ومجرورا وهو " نـا " ، وتكون للمتكلم

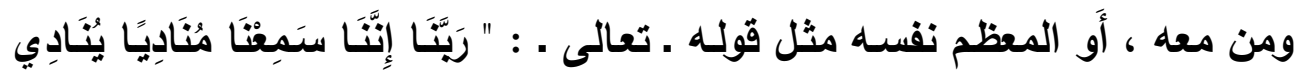

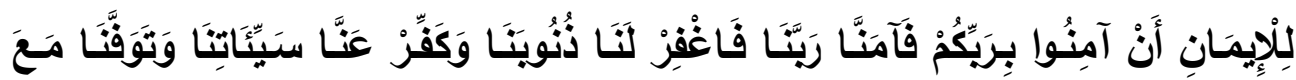

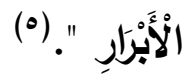
والضمير المتصل لا يبتدأ به (؟) . كما سبق . ، وهو أصل للمنفصل ، وأخصر

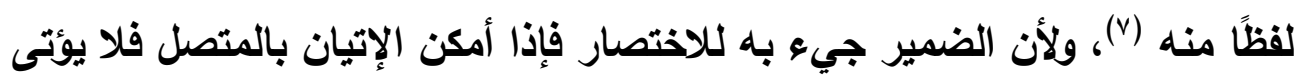
بالمنفصل (^) إلا في ضرورة الثعر عند الجمهور ، كقول حميد الأرقط :

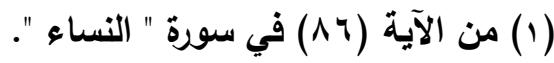

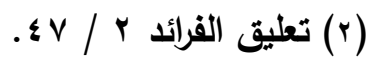

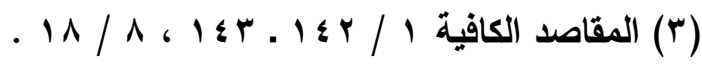

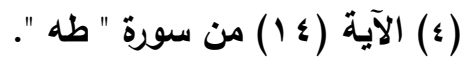

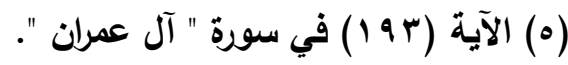

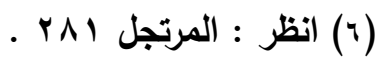

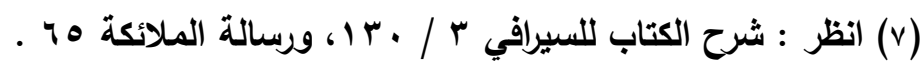

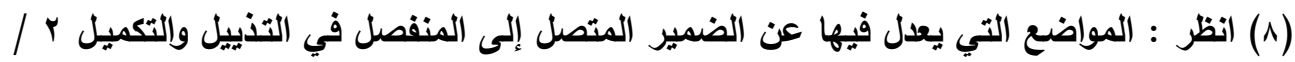




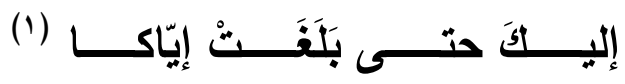

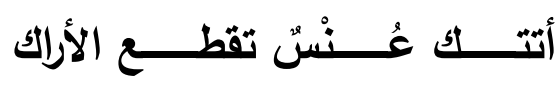
وقوله :

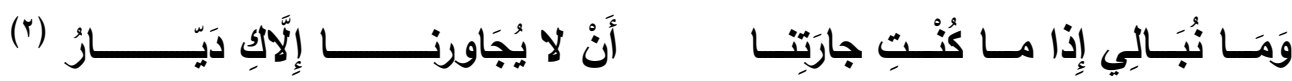

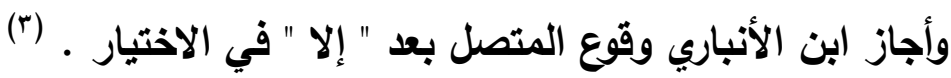

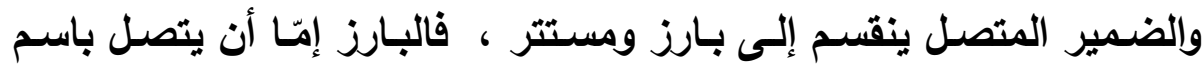
كالكاف في " غلامك " ، أو بفعل كالتاء في " ضربت " ، أو بحرف كالكاف في " لك

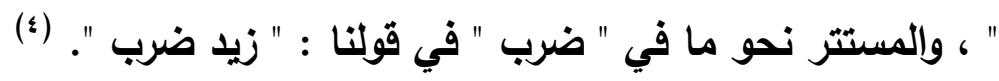

\section{الإقابل}

يقابل المتصل هنا المنفصل ، وهو ما استقلّ بنفسه . ويبتدأ به في أول الكلام ، سواء كان مرفوعًا أو منصويًا ، فهو مستقل بنفسه هوله ، فيقال: " أنا مؤمن ، وإياك أكرمت ".

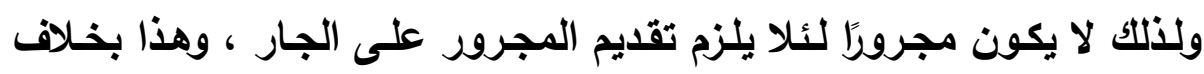

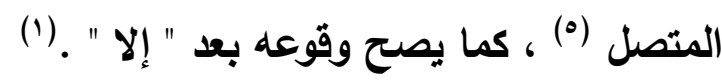

$$
\begin{aligned}
& \text { O ا ب ، وما بعدها . }
\end{aligned}
$$

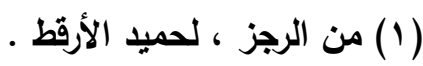

العن هي الناقة القوية على السير ، و" تقطع الأراك " يعني الأرض التي هي منبت الأراك.

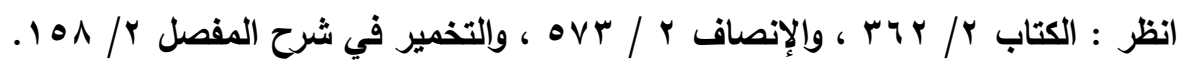

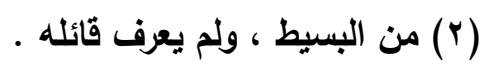

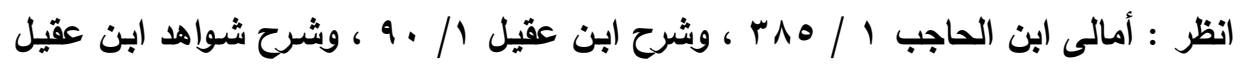

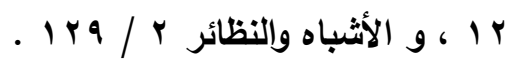

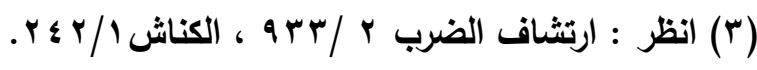

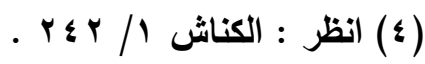

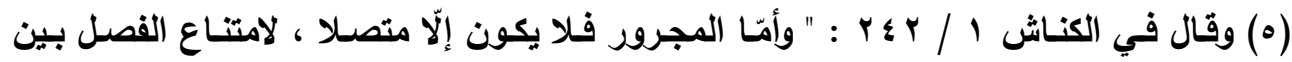


والضمائر المنفصلة أربعة وعشرون ضميرًا ، منها اثنا عشر ضمائر رفع ،

وإثنا عشر ضمائر نصب . (r)

فضمائر الرفع تأتي في خمسة مواضع :

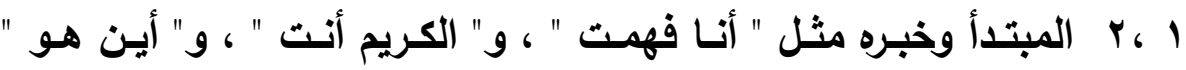

فالمبتدأ وخبره العامل فيهما الابتداء ـ على الأصسح ـ وهو عامل معنوي ، فلا يمكن

وصل معموله به ، فلالك وجب أن يكون ضميرهما منفصلً .

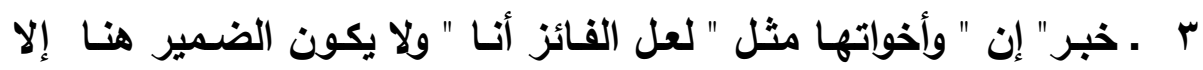
منفصلًا ؛ لأنـه لا يصـح اتصـاله بالعامل فيه ؛ لأن مرفوع " إن " وأخواتها لا يتقدم

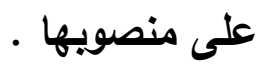

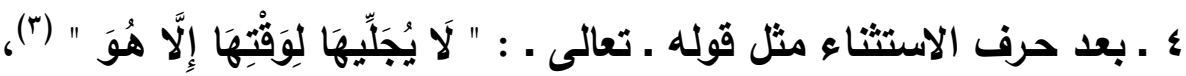
وقول عمرو بن معد يكرب ـ ونسب للفرزدق . :

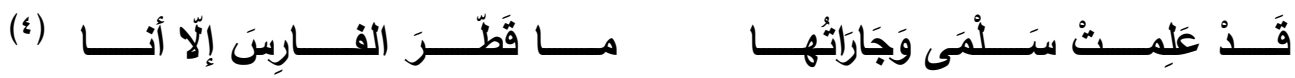
وقوله :

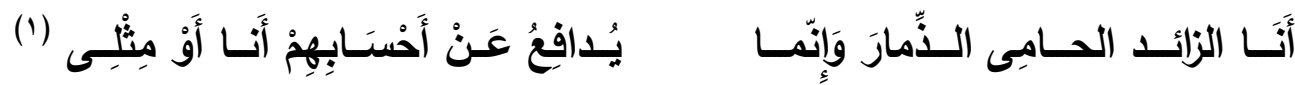

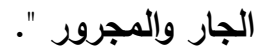

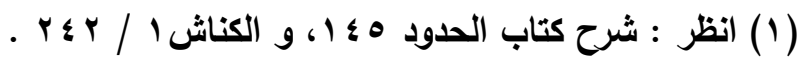
. rVr انظر : شرح الوافية (r)

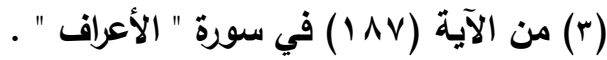

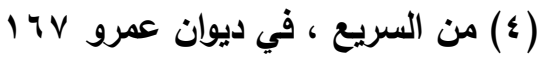
وقطر الفارس قتله .

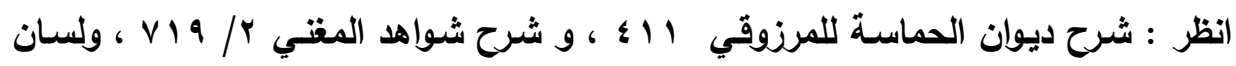

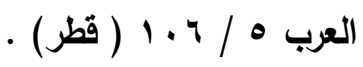


ه ـ بعد حرف العطف مثل " جاء عبدُ الله وأنتَّ " ؛ لأنه وقع بعد حرف العطف

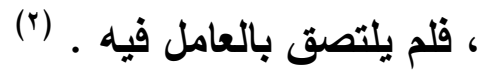

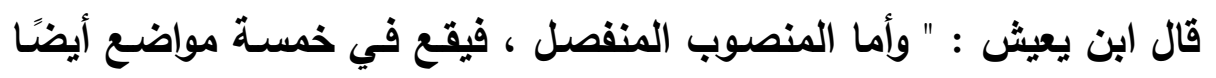

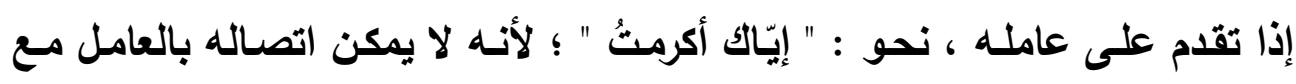

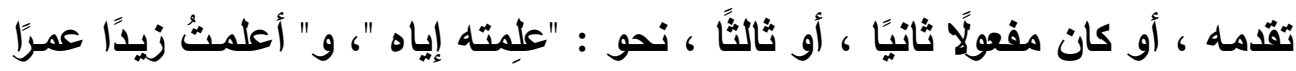

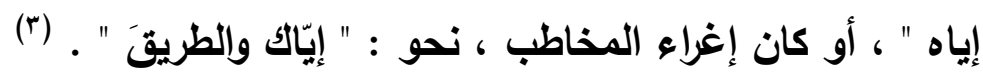

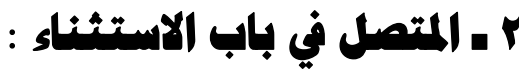

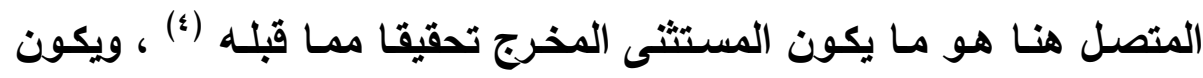

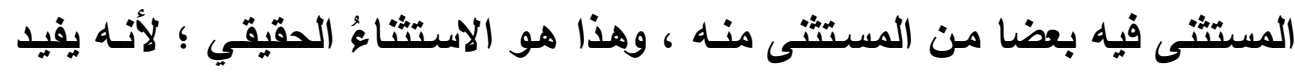

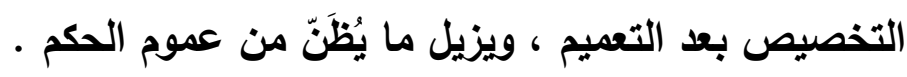
والاستثناء المتصل يكون تاما موجبا ، وتاما منفيا .

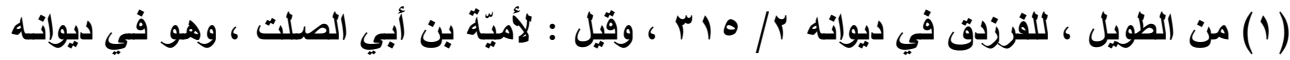

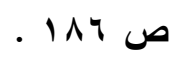

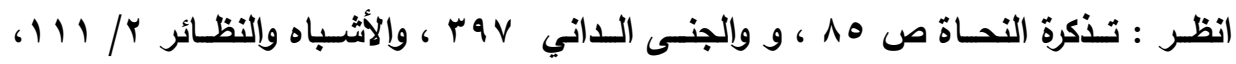

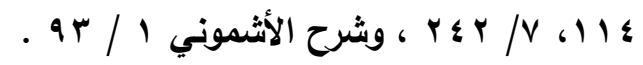

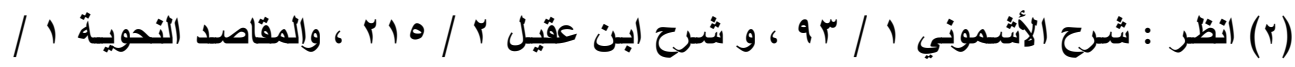
.$\nvdash \wedge \varepsilon$

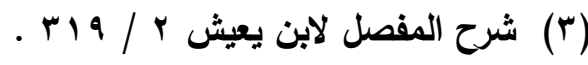

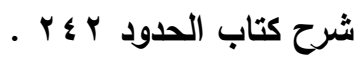


فالتمام معناه أن يكون المستثنى مذكورًا في الكلام ، سواء أتقدم المستثـى على المستثنى منه ، أم تأخر ، مثل " جاء القوم إلازيدًا " ، و "جاء إلا زيدًا القوم

وعدم التمـام معناه ألا يكون المستثنى منه موجودًا ، مثل " ما جاء إلا زيــ "

والإيجاب معناه ألا يكون في أول جملة الاستثناء نفي ، أو نهي ، أو استفهام

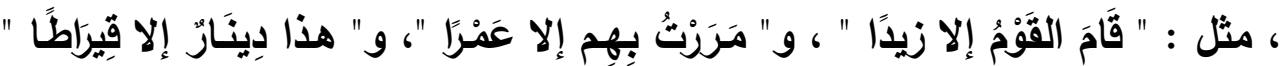

قال ابن يعيش : " الموجب من الكلام ما ليس معه حرف نفي ، والمثبث من الأفعال ما وقع وحدث ، فقولك : " قام زيدٌ " موجب مثبت ، موجب لأنه ليس بمنفي

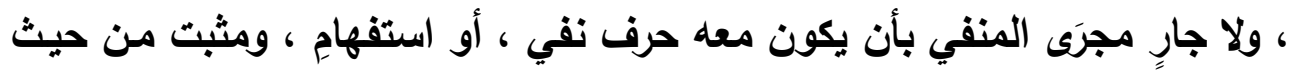

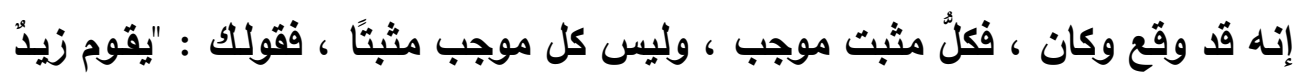
" موجب لعدم النافي ، أو مـا يجري مجراه ، وليس بمثبت ، والعبرة في الاستثناء

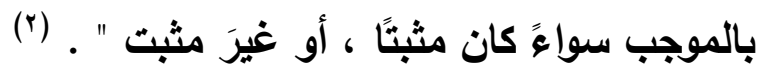
والنفي يتحقق بأن يكون في الجملة نفي ، أو نهي ، أو استفهام ، مثل " مـا

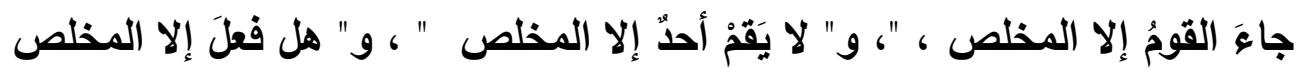

وقد يكون النفي معنويا ، لا بالأداة ، مثل " أقل رجلٍ يقول ذلتك إلا زيـدٌ " ، و"

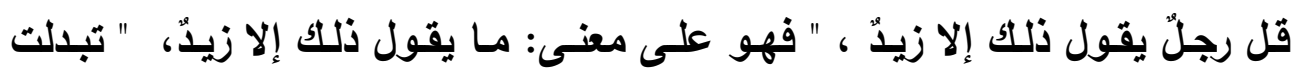
أخلاق القوم إلا المتقي ربـه " ومعنـاه لم تَبَقَ أخلاقهم على مـا كانت عليهـ ، ومنـه

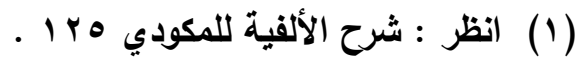

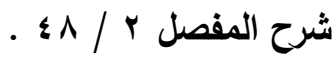




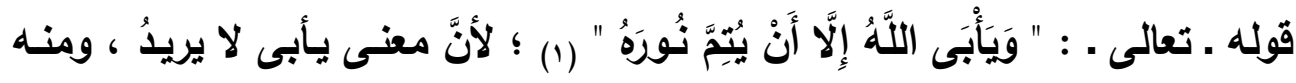
ومنه ما أنثد الأخفش من قول الثاعر :

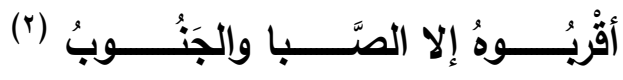

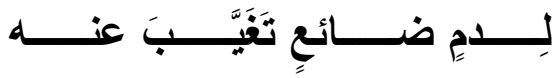

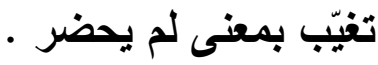

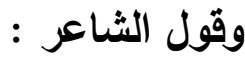

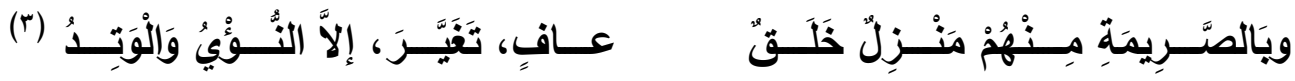

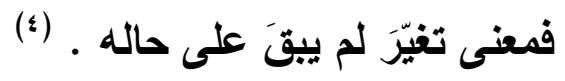

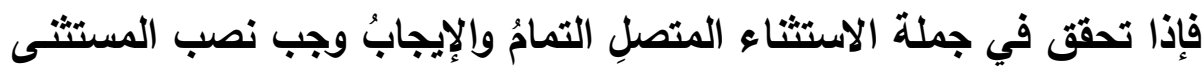

وإذا تحقق الإيجـاب وإلنفي بـالأداة جـاز في المستثنى النصب ، والإتبـاع

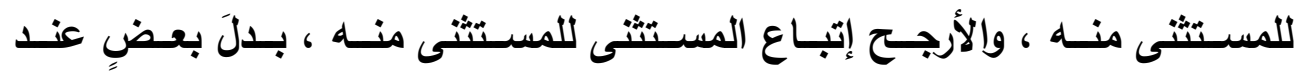

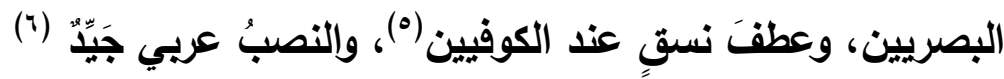

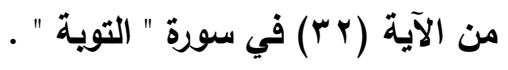

$$
\begin{aligned}
& \text { من الخفيف لأبي زيبد الطائي . }
\end{aligned}
$$

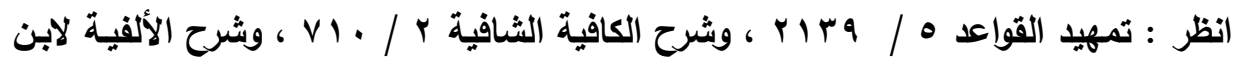

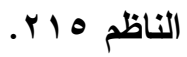

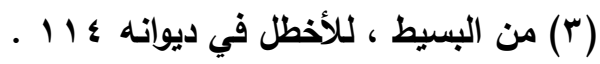

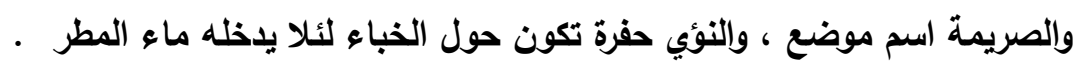

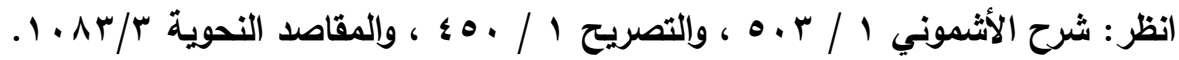

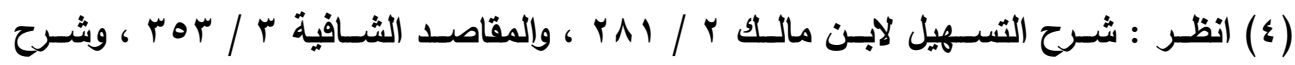

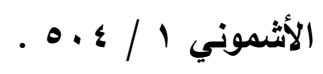

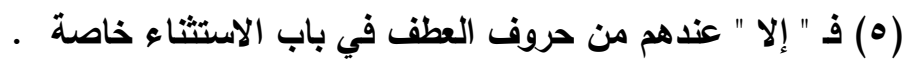

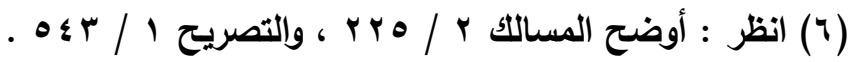


وأيضا إذا كان النفي معنويا جاز الوجهان ؛ لجواز مراعاة اللفظ أو المعنى ، فقي اللفظ الكلام تامٌٌ مستوفٍ ركنيه ـ المسند والمسند إليهه ـ فينصب المستثنى لأنـه فضلة ، وفي المعنى المستثنى هو المسند إليه في الحقيقة ، فصح تفريغ العامل له ، وتسليطه عليه .

وإذا كان غير تام ـ ولا يكون إلا منفيا ـ سمي مفرغا (1) ، وأعرب المستثنى

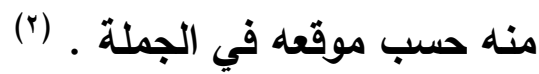

\section{الإقابل}

ويقابل المتصل هنا المنقطع .

وعرَّف النحويون المنقطع بأنه ما لا يكون فيه المستثنى من جنس المستثنى منه مثل " حضر القوم إلا الحميز " . قيل : وهذا التعريف جريٌ على الغالب ؛ لأنه قد يكون من الجنس ولكنه خارج عنه حين إطلاق الحكم عليه . قال الفاكهي ـ في تعريف الاستثناء المنقطع . : " هو ما لا يكون المستثىى المخرج تقديرا مما قبله بعض المستثنى منه ، سواء كان من غير جنس مـا قبله وهو ظاهر - ، أو من جنسه : " جاء القوم إلا زيدا " مشيرا بـ " القوم " إلى جماعة ليس زيد منهم •

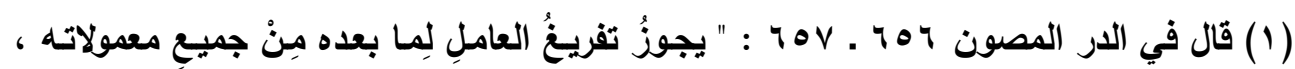

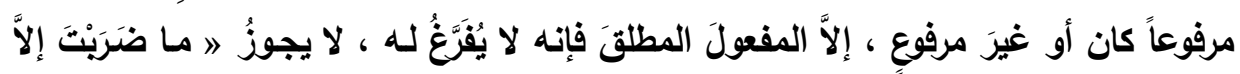

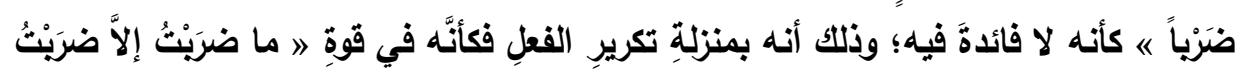

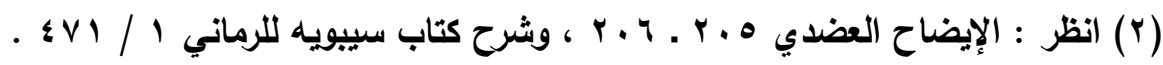


فقد استبان لك أن كل استثناء من غير الجنس منقطع ، ومن الجنس يحتمل الانقطاع والاتصال .

فتعريف بعضهم المنقطع : " يكون المستثنى من غير جنس المستثنى منه

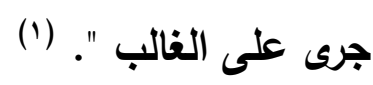

ودخول المنقطع في تعريف الاستثناء ـ حقيقة أو مجازًا ـ متوقف على تعريف

$$
\text { النحويين للاستثناء . }
$$

قال في اللمع : " ومعنى الاستثناء أن تخرج شينًا ممـا أدخلت فيه غيره أو

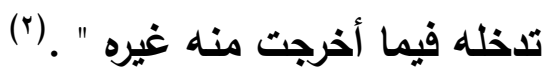

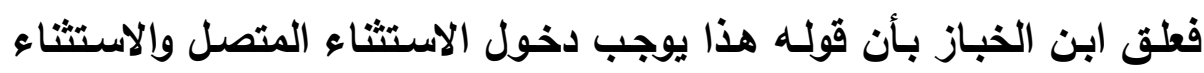

المنقطع تحته ، ويكون في كليهما حقيقة .

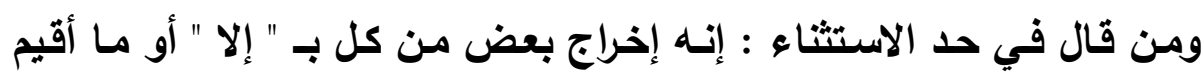

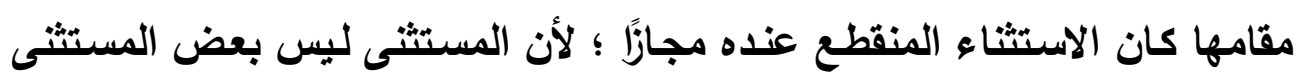

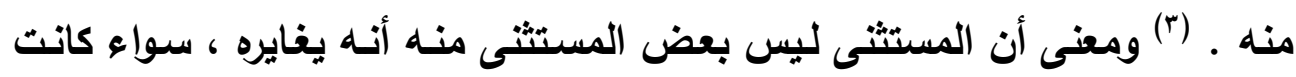

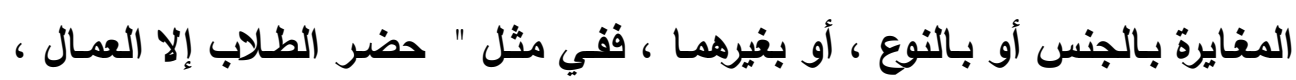

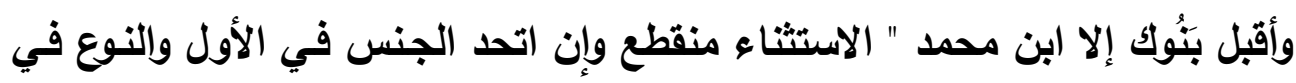

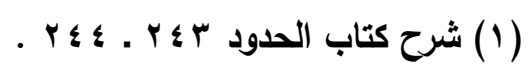

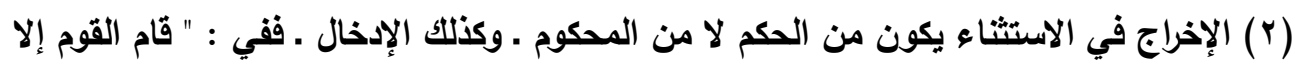

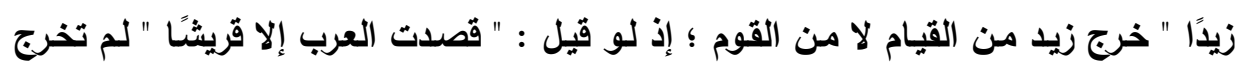

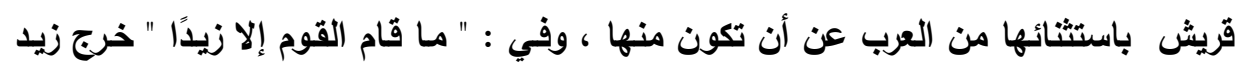

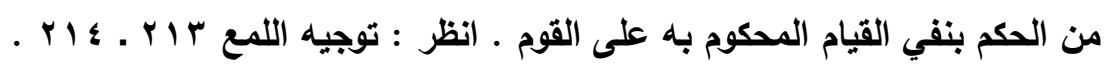

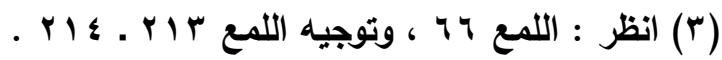


الثاني ، إلا أن العمال ليسوا من بعض الطلاب وابن محمد ليس بعضـا من أبناء

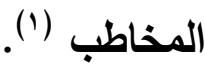

وميع أن المستثىى هنـا لا يتناولـه لفظ المستثنى منـه إلا أنـه لابـ من ارتباط

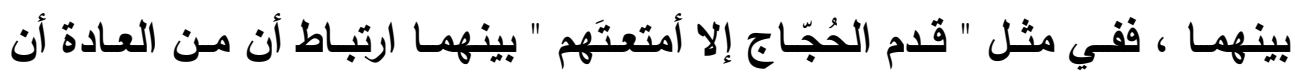

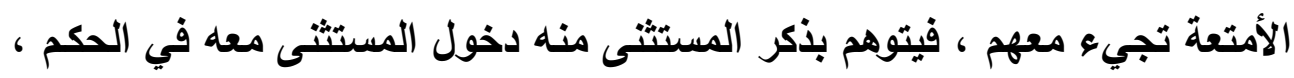

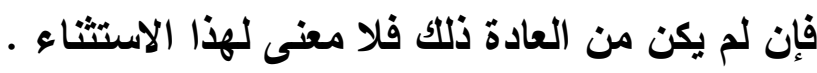

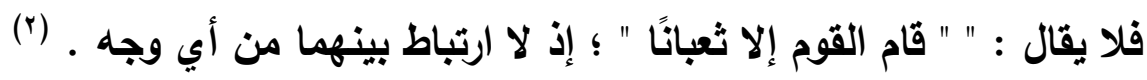

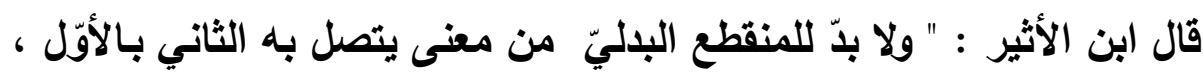

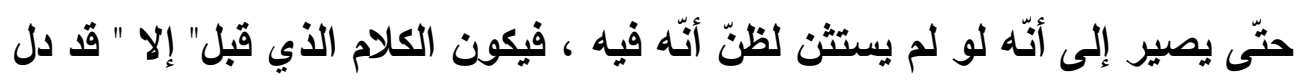

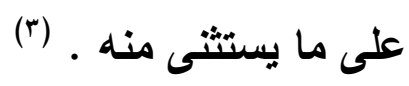
وفائدة ذكره ـ مـع أنـه مغاير ـ الاستـراك ؛ إذ هو إثبات معنى ممكن الوجود

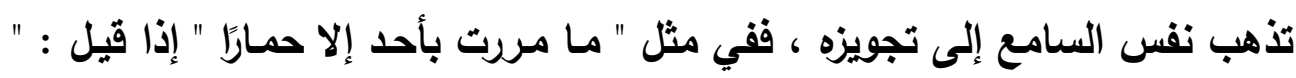

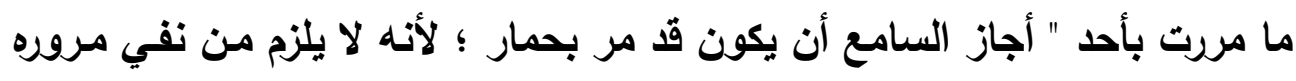

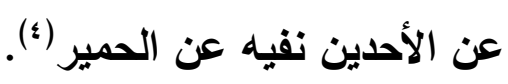

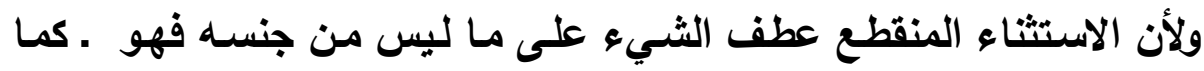

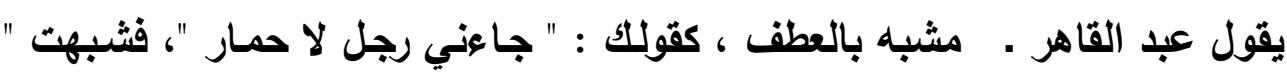

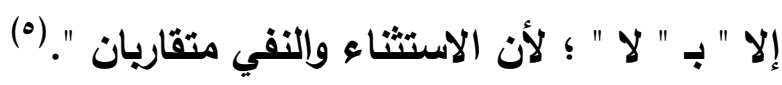

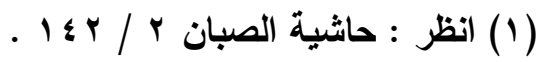

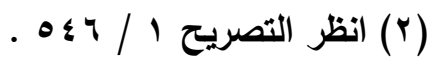

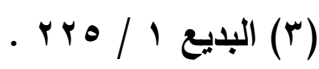

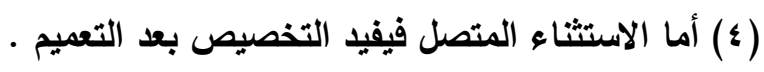

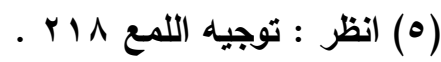


قال في البديع : " وأمّا المنقطع فهو : أن يكون المستثنى من غير جنس

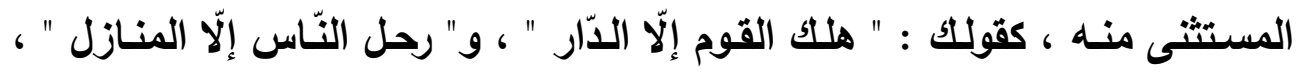

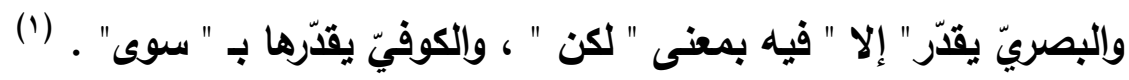

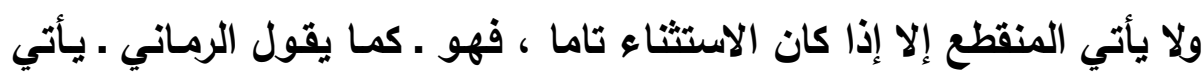

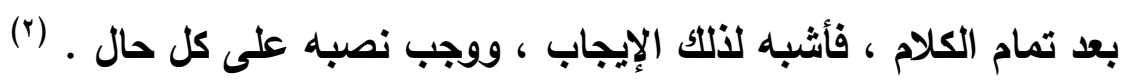

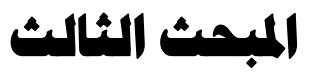

\section{|النصامص}

أ ـ الناقص في باب الإعراب والبناء : ا - المنقوص :

المنقوص هو الاسم المعرب الذي آخره ياء لازمة قبلها كسرة مثل "الداعي" و

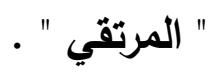

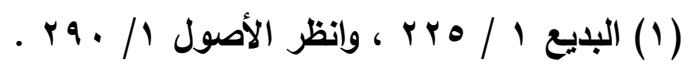

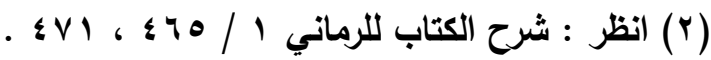


وســـي منقوصنَا لحـف لامسه للتــوين ، أو لأنسه نقص منـه ظهـور بعض

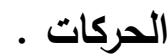

ويسمى ـ أيضًا ـ معتلًّا ؛ لأن آخره حرف علة ، أو لأنهـ يُعَلٌّ آخره بالحذف .

والاسم المنقوص تقدر عليه الضمة والكسرة استثقالًا (؟) ، كقوله ـ تعالى . :

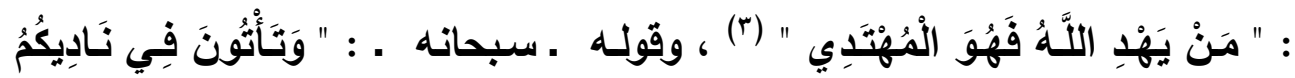

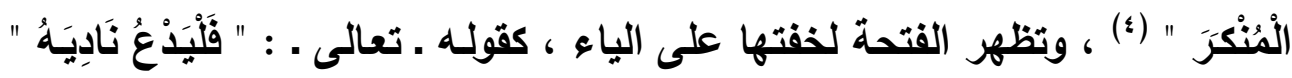
(॰) "

وياء المنقوص تحذف مع حركتها ، وتبقى الكسرة قبلها تدل عليها ، ويعوض عنها التنوين وذلك في حالتي الرفع ، والجر ، مع عدم وجود " ال " ، وذلك لاجتماع

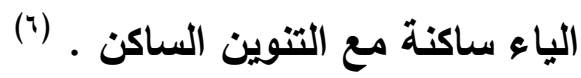
وفي هذه الحالة تقدر علامـة الإعراب ـ وهي الضمة ، أو الكسرة . على يائهـ

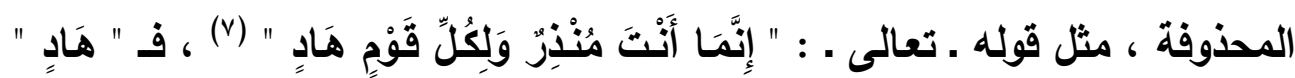
مبتدأ مؤخر مرفوع ، وعلامة الرفع ضمة مقدرة على الياء المحذوفة وعوض عنها • التنوين

$$
\text { . VV . VY/ انظر : شرح الأشتموني (1) }
$$

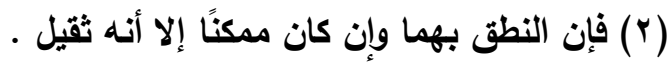

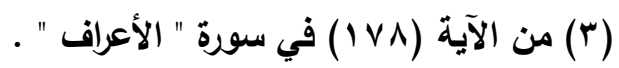

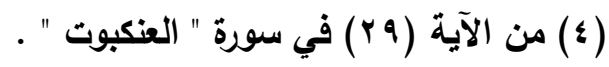

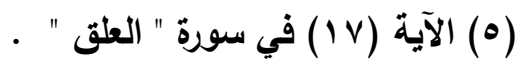

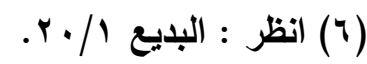$$
\text { (V) من الآية (V) في سورة " الرعد ". (V) }
$$ 


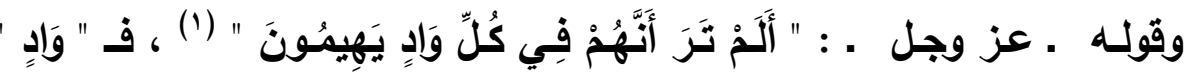

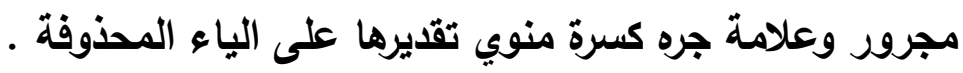

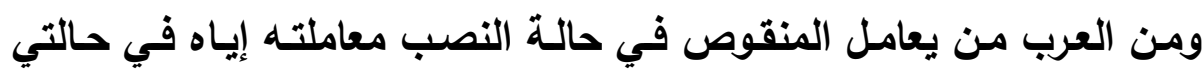

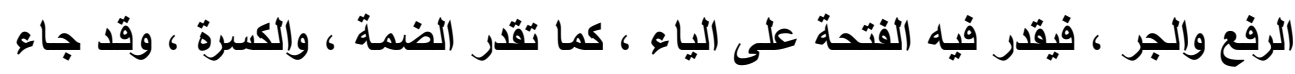

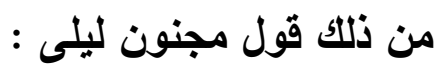

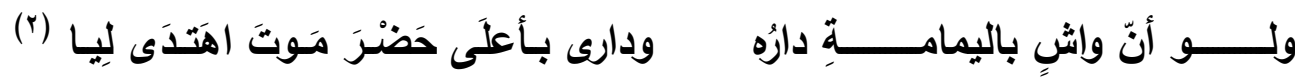

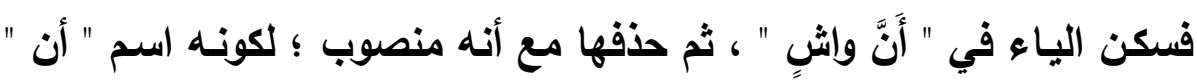
ـ وقال رؤية :

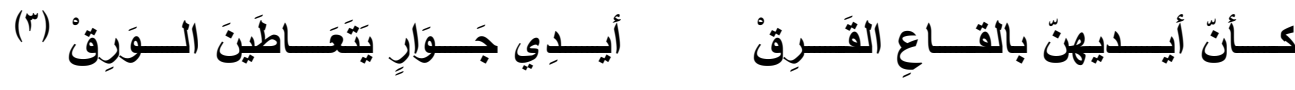

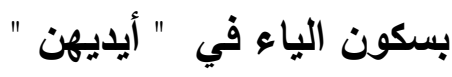

وقد اختلف النحاة في ذلك ، فقال المبرد : هو ضرورة ، وأكنها من أحسن

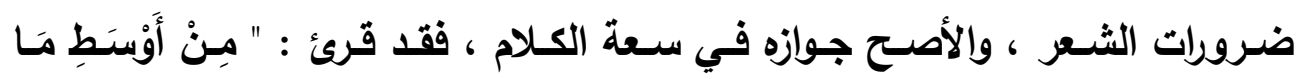

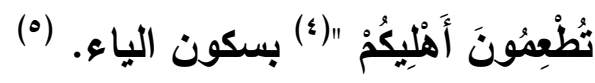

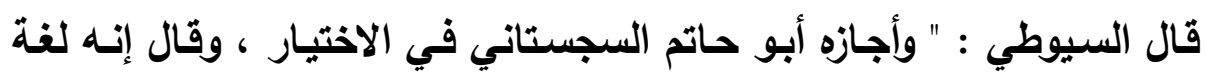

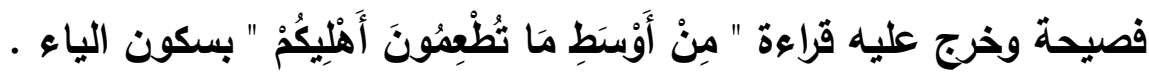

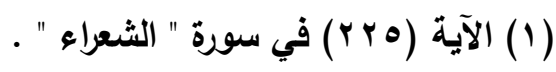

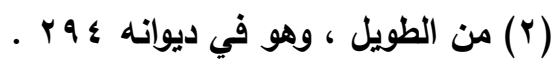

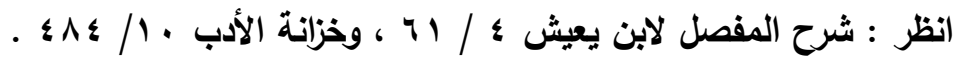

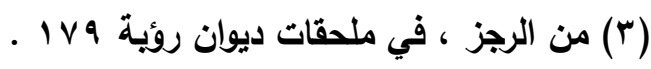

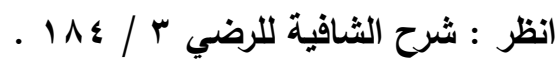

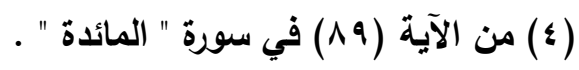

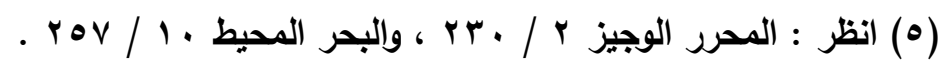




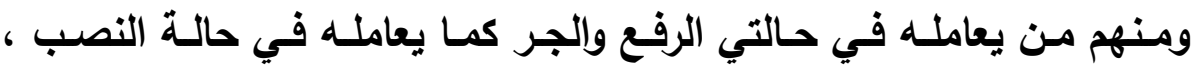

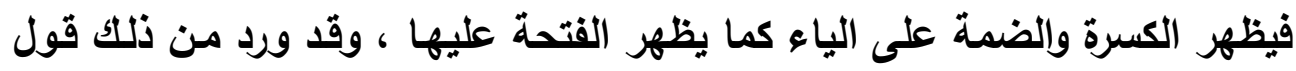

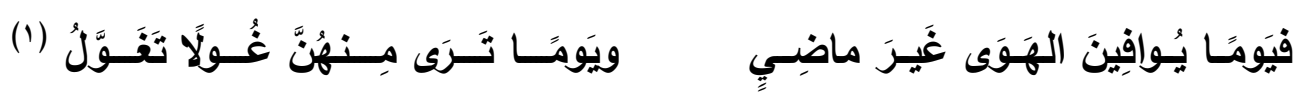
جريز

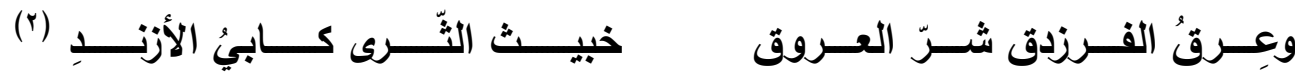
و " كابئ الأزند " أي زنده لا يقدح ومعناه : لا خير فيه ، فقد ظهرت الضمة

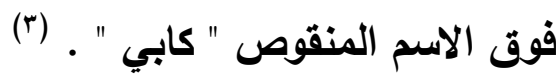

ولا خلاف بين أحد من النحاة في أن هذا ضرورة لا تجوز في حالة السعة .

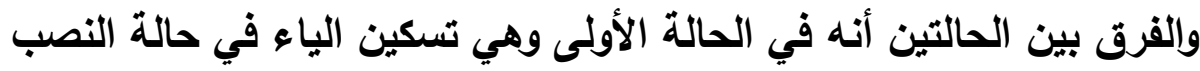
حمل حالة واحدة ـ وهي النصب ـ على حالتين ـ وهما الجر والرفع ـ فقيه حمل الألقل

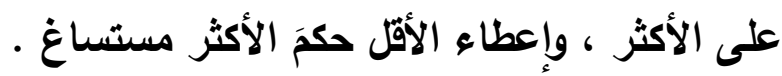

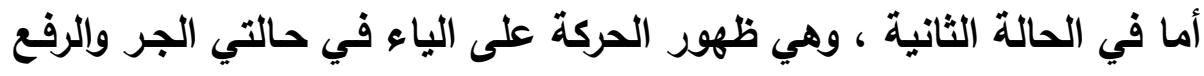

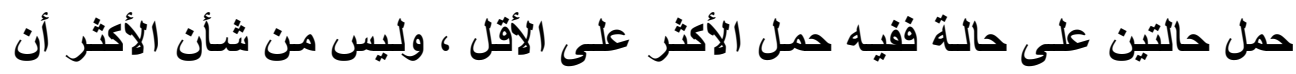

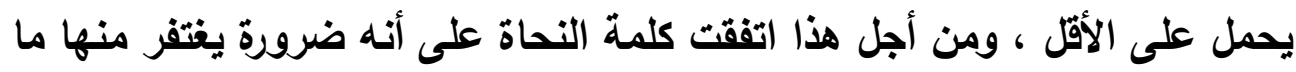

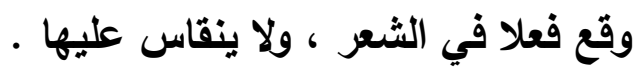

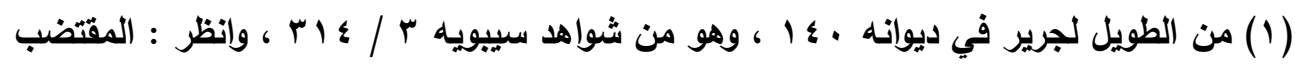

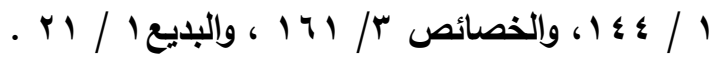

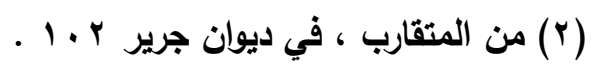

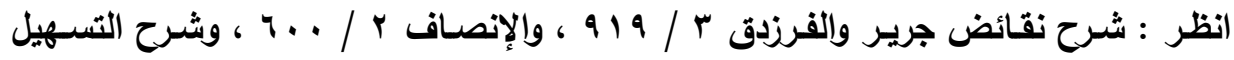

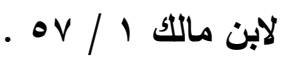

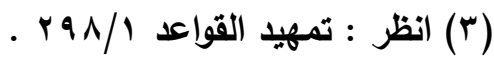


قال ابن الشجري : " قال المبرد : هذا من أحسن الضرورات ؛ لأنهم ألحقوا

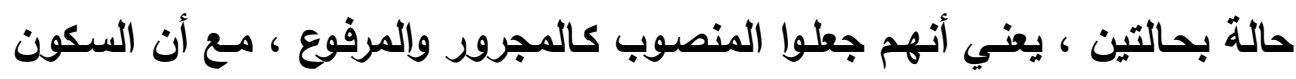
أخف من الحركات ، ولذلك اعتزموا على إسكان الياء في ذوات الياء من المركبات ،

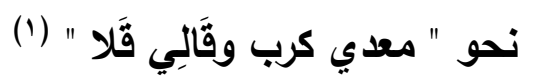

\section{المقابل}

ويقابل المنقوص هنا الاسم المقصور ، وهو كل اسم وقعت في آخره ألف

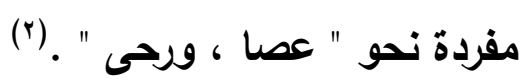

ومقابلته للمنقوص من جهة أنه منع من ظهور جميع حركات الإعراب الثُلاث

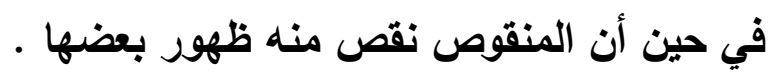

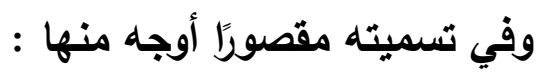

أن الإعراب قصر فيه ـ فكأن المراد المقصور فيه الإعراب ـ . فحدث حذف حتى إنى

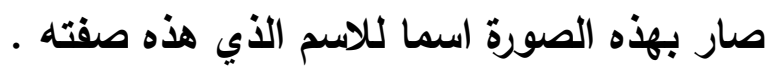

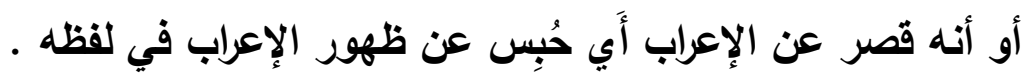

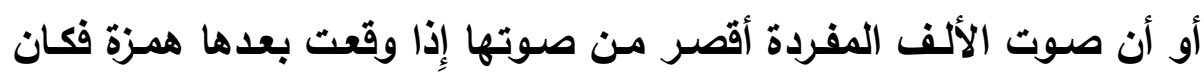

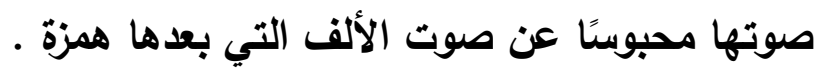

أو أنه نقيض الممدود . (r)

وهو ينقسم قسمين :

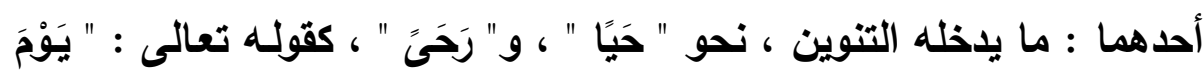

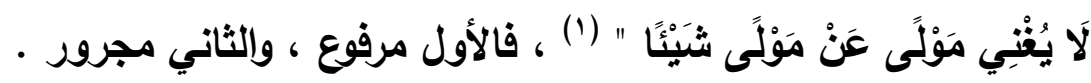

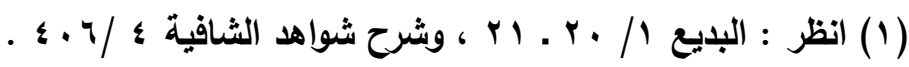

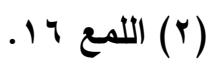

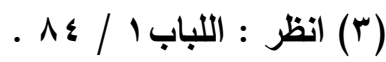


والثانسي : ما لا ياخله التتوين ، وذلك إما أن يكون علمًا غير منصرف ، ك

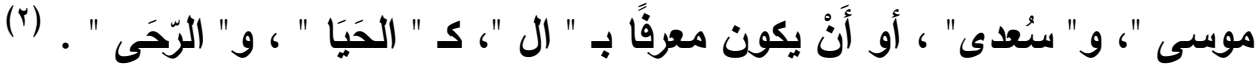
فما كان منصرفًا تحذف ألفه في الوصل لالتقاء الساكنين ( سكونها ، وسكون

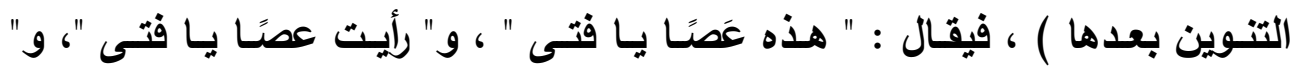
أمسكت بعصنًا يـا فتى " ، والتتـوين بعد الصساد في اللفظ ، وبعد الألف في التقدير لأن التنوين لحق الاسم بعد آخره . فَإذا وُقِف عليه عادت الألف ، وكان الوقف عليها ، فيقال : " هذه عَصا "و" أيث عصا "، و" أمسكت بعصا "، وذلك لخفة الألف . (r)

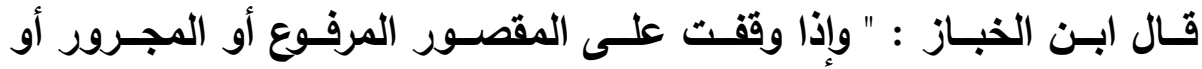
المنصوب في حال تنوينه كقولك : " هذه عصـا " ، ورأيت عصا ، ومررت بعصا " فقيه للنحويين ثلاثة أقوال :

$$
\text { أحدها : وهو قول سيبويه(؛)، ـ وهو أحد قولي الفارسي . (•) : }
$$

وهـو أنــك تجـري المعتل مجـرى الصـحيح ، ومعنى ذلــك أن الوقف علـى الصحيح في حالتي الرفـع والجر على حرف الإعراب ، وفي النصب على الألف التي هي بدل من التنوين كقولك : " هذا زيد ومررت بزيد ، ورأيت زيدًا " .

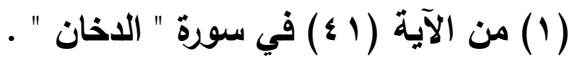

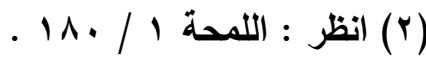

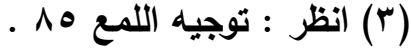

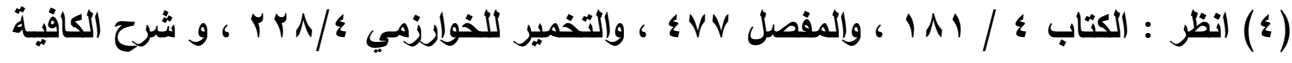


فإذا قلت : " هذه عصا " ، ومررت بعصا " حكمت بأن الألف حرف الإعراب

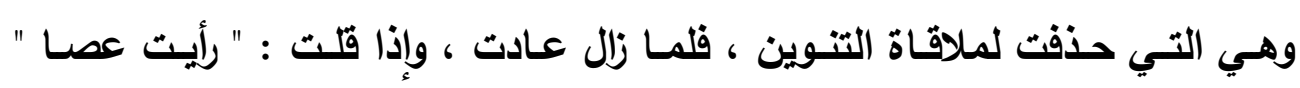

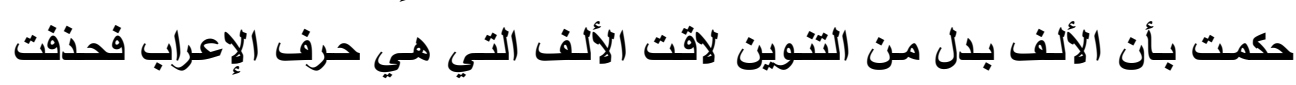

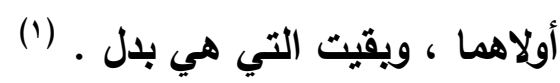
والقول الثاني : قول أبي عثمـان المـازني (ץ) ، وهو أن الألف في الأحوال

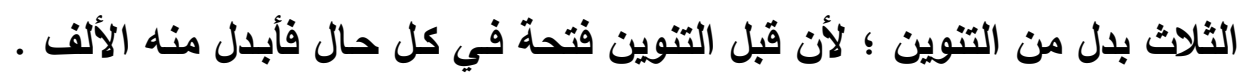

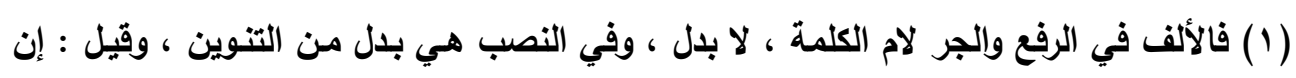

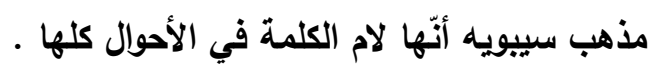

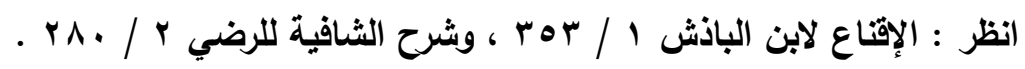

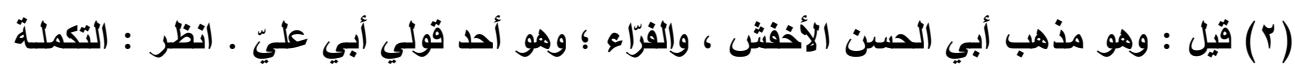

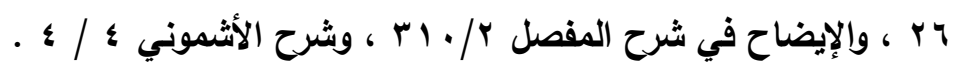


والقول الثالث : قول أبي سـعيد السيرافي (1)، وهو أن الألف في الأحوال

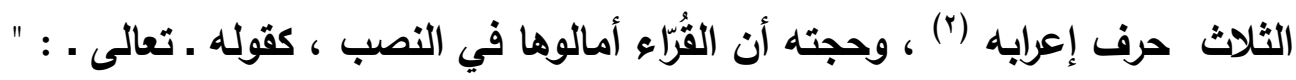

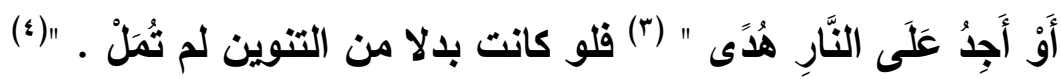

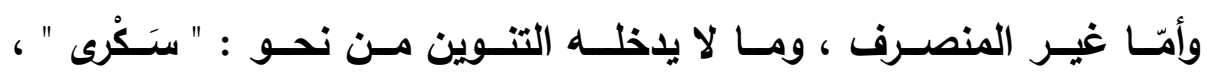

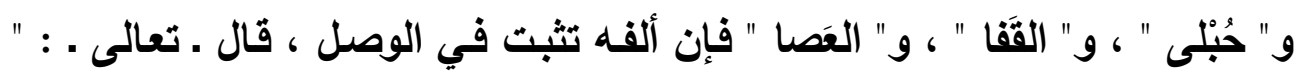

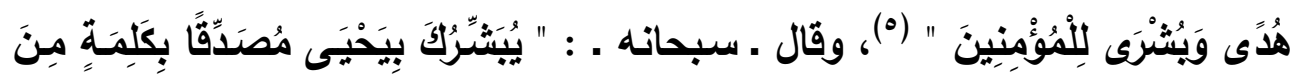

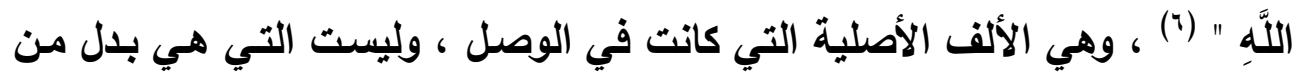

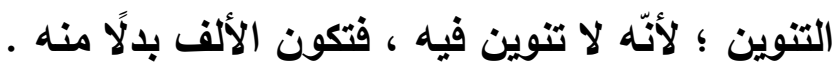

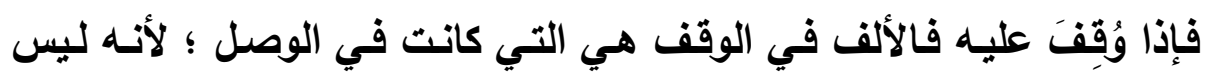

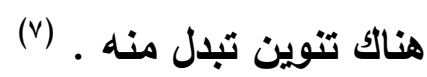

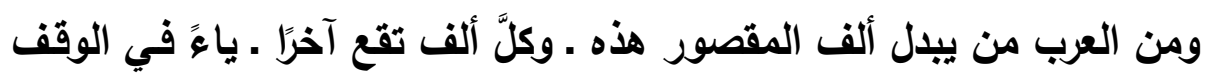

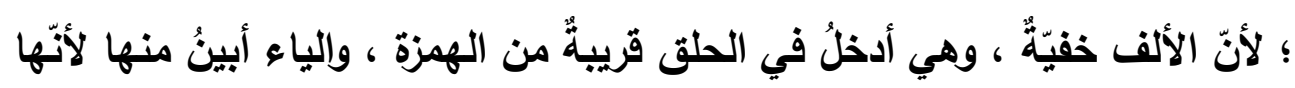

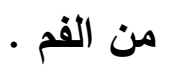

(1) نُسببَ هذا الترأي إلى أبي عمرو بن العلاء ، والكوفيَيَن ؛ وإليهه ذهب ابن كَيْسان والسيّيرافيّ

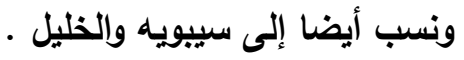

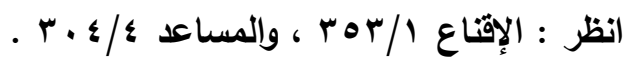

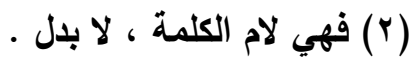

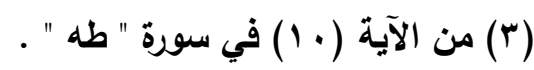

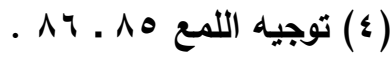

$$
\begin{aligned}
& \text { (0) الآية الثانية في سورة " النمل ". }
\end{aligned}
$$

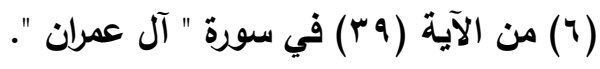

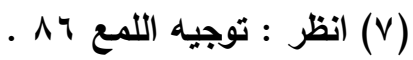


قال سيبويه : " باب الحرف الذي تبلال مكانه في الوقف حرفًا أبين منه يشبهه

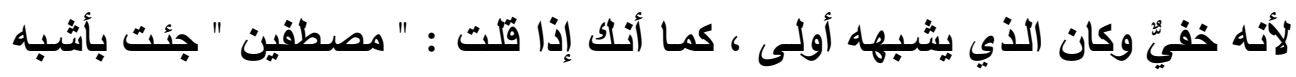

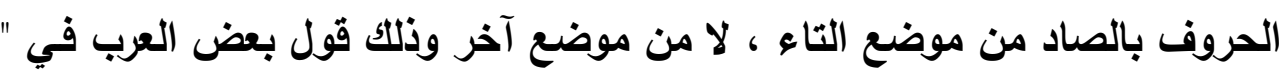

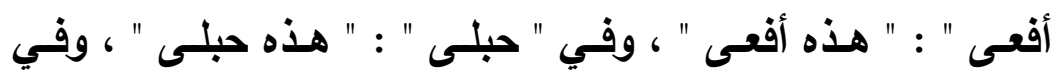

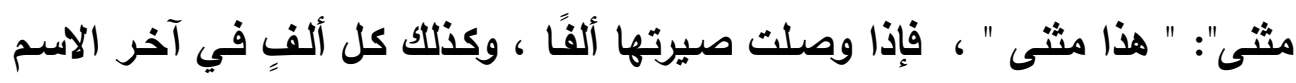

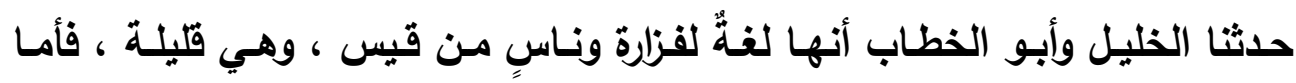

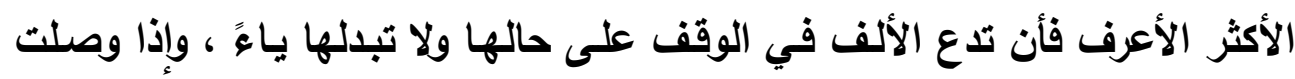

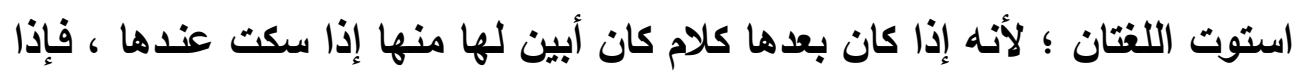

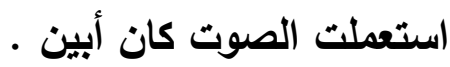
وأما طيىء فزعموا أنهم يدعونها في الوصل على نـ حالها في الوقف ؛ لأنها

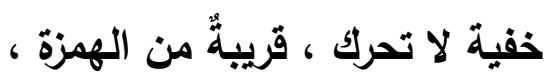

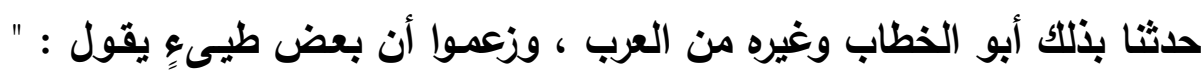

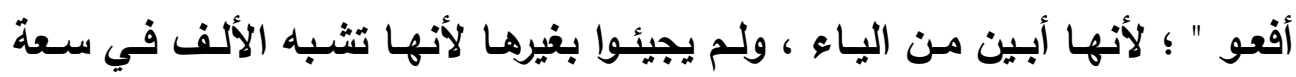

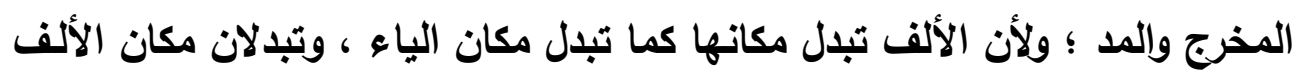

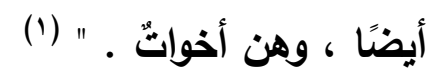
والقصر في الأسماء على ضربين : قياسي ، وسماعي .

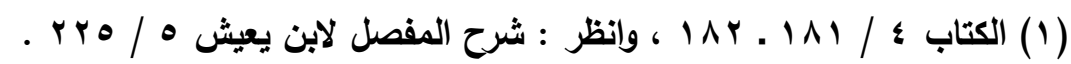

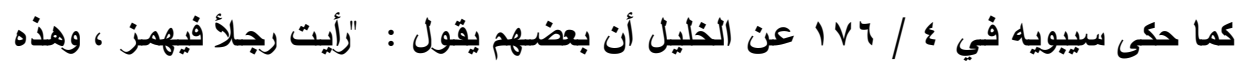

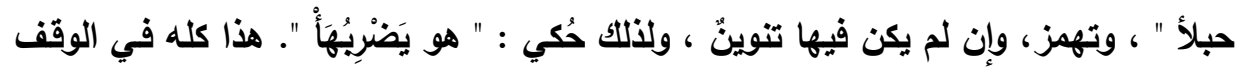

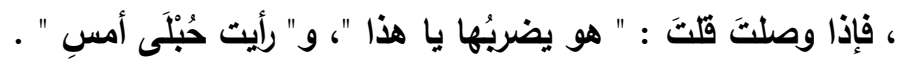

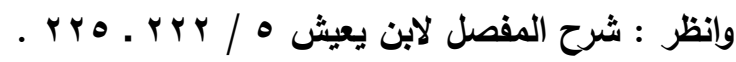


فالقصر القياسي : في كل معتل له نظير من الصحيح مطرد فتح ما قبل آخره

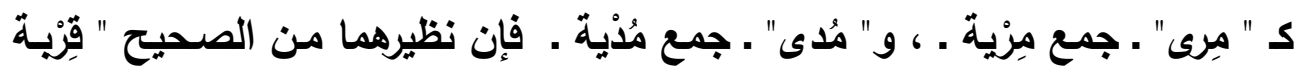

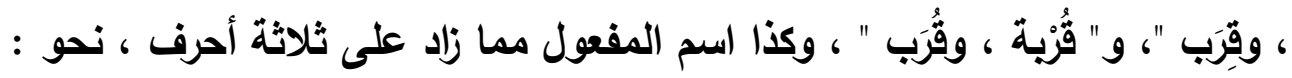

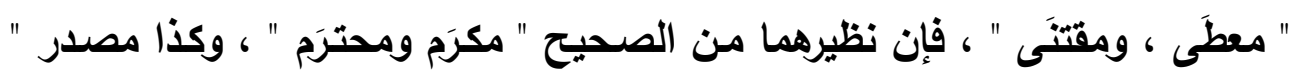

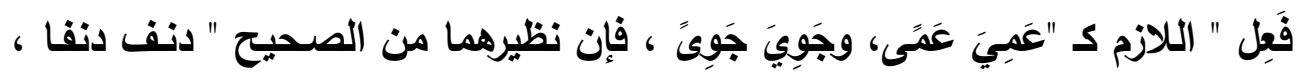
وأسف أسفا " .

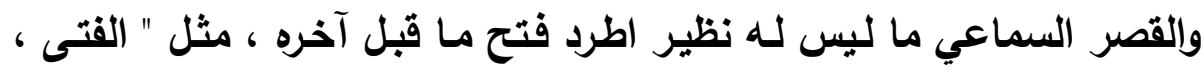

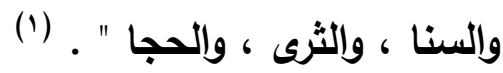

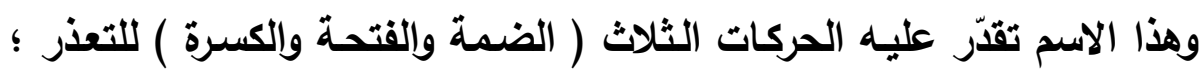

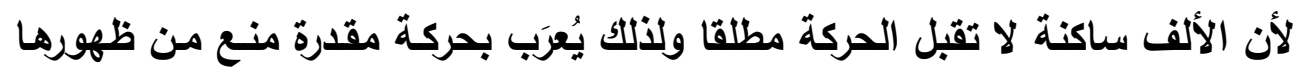

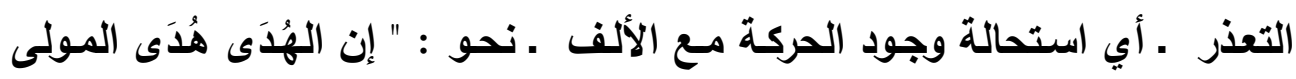

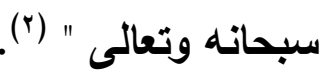




\section{r النقص في الأسمهاء الستة}

الأسماء الستة هي : أب ، وأخ ، وحم ، وفو ، وذو ، وهن ، بشروطها التي

ذكرها النحاة. (1)

\section{وتسمى معتلة ، ومضافة .}

قال ابن الخثاب : " سميث هذه الأسماء معتلة لكون لاماتها حروف اعتلال

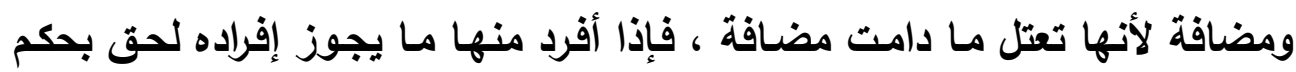

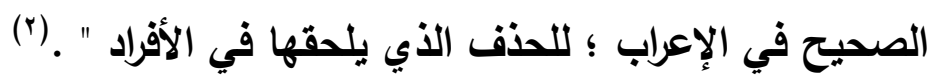

والنقص في هذه الأسماء أن تحذف لام الكلمة ، فتصبح على حرفين ، ويهذا الأنا

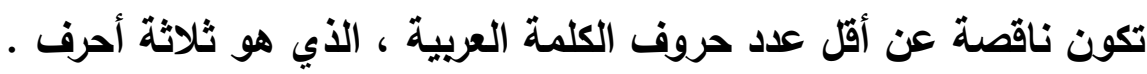

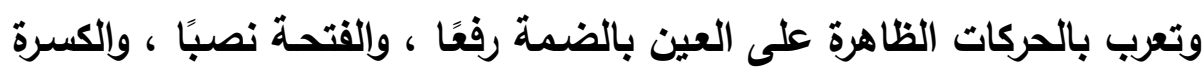

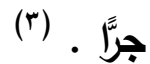

وهذه إحدى اللغات في الأسماء الستة ، وتسمى " لغة النقص " . والمراد بالنقص هنا النقص اللغوي ، وهو أن تحذف لاماتها ويجعل الإعراب الإني

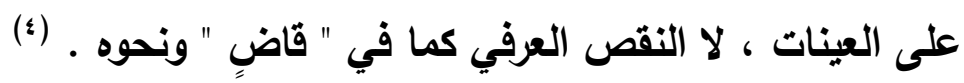

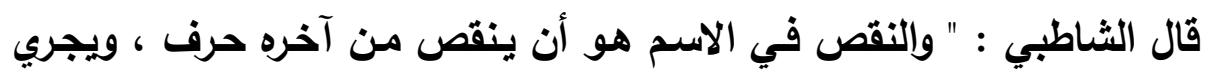

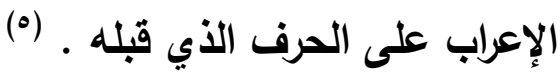

(1) انظر هذه الثروط في توجيه اللمع 19 ـ .

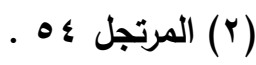

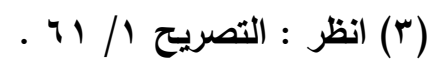

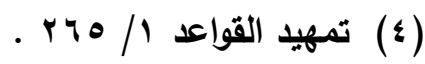

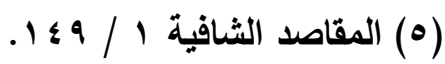


ويدخل النقص أربعة من الأسماء الستة، هي " أب ، وأخ ، وحم ، و هن " . أما نقص " أب " فشاهده قول الراجز : خبيث الثّى كابيُ الأزندِ (1)

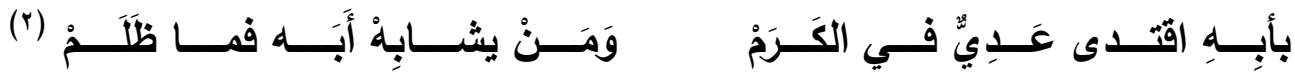
وأما نقص " أخ " فثـاهده حكاية أبي زيد : " جاعني أخُك " .

قال في النوادر : وقد يقال : " أخ وأخان وأخُون وأب وأبان وأبُون " (r) وقول عقيل بن علفة المري :

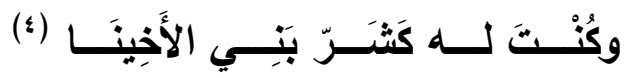

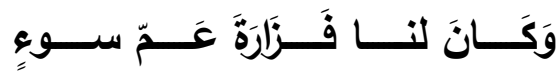
قال: أراد الإخوة .

وأما نقص " حم " فما حكاه الفراء أنه يقال : " هذا حمُك " . (•)

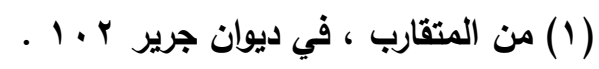

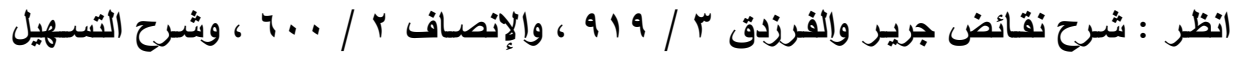

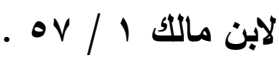

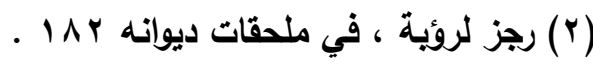

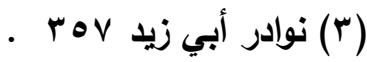
( ) ( ) من الوافر

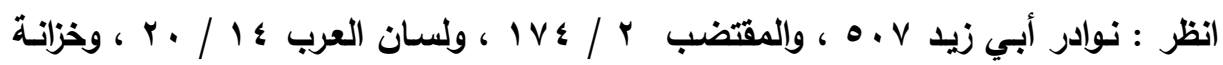

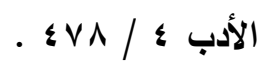

(0) انظر : التنييل والتكميل / / 171 ( 14 


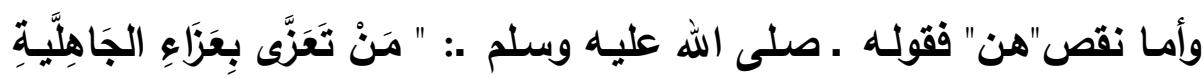

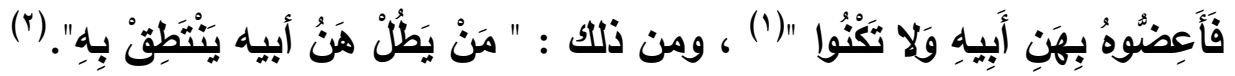
وأنشد سيبويها :

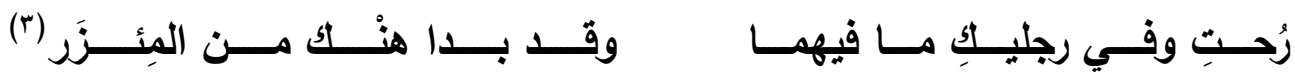

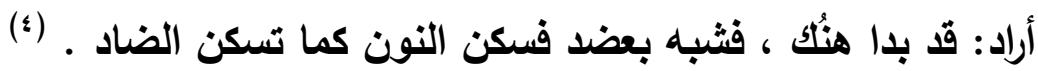

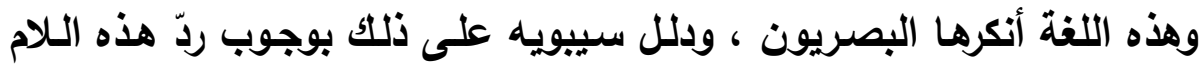

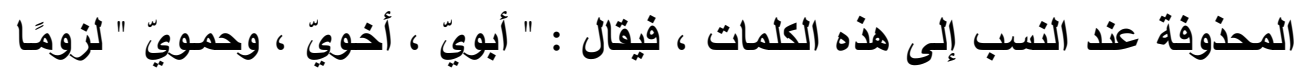

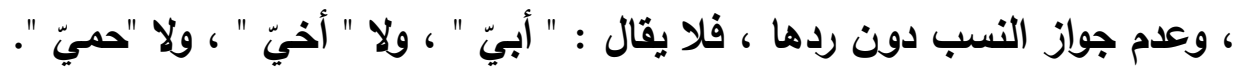

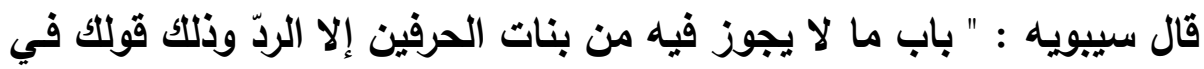

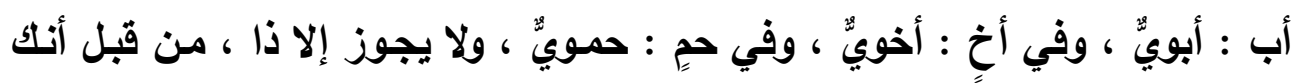

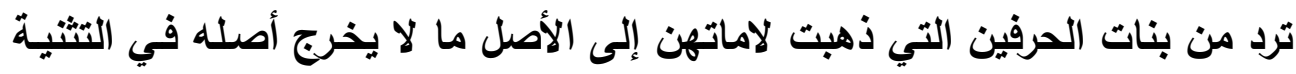

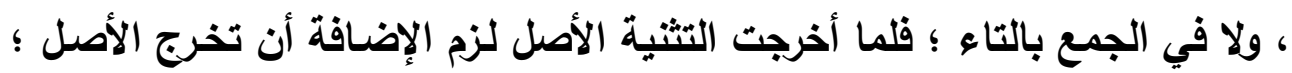

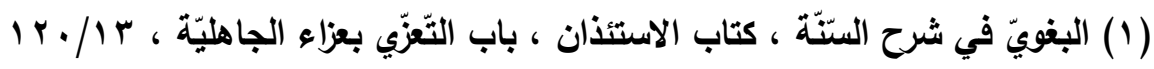

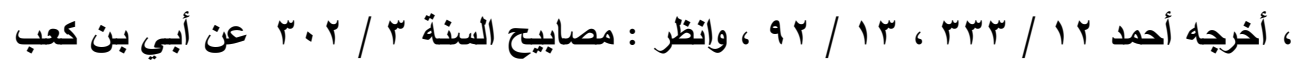

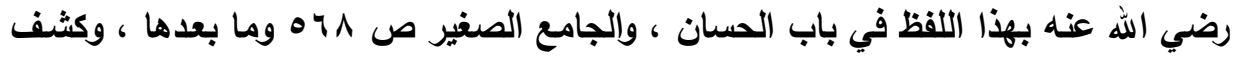

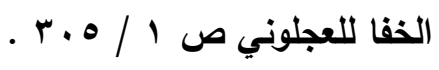

(r) نسب إلى أمير المؤمنين علي ـ رضي الله عنه . . ، ومعناه من كثر ولد أبيه يتقوى بهم انظر

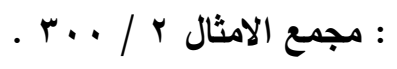

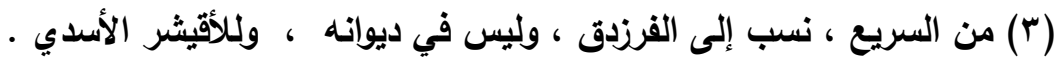

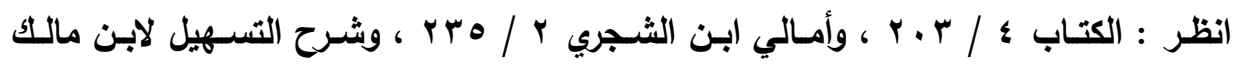

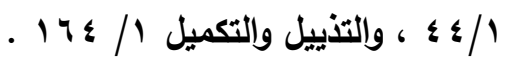

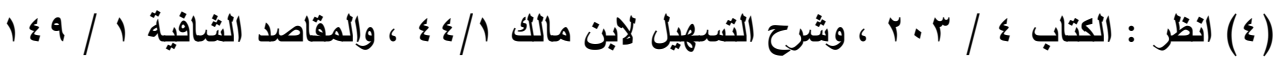


إذ كانت تقوى على الرد فيما لا يخرج لامه في تثثيته ولا في جمعه بالتاء ، فإذا رد

$$
\text { في الأضعف في شيع كان في الأقوى أردَّ ". (1) }
$$

قال الفارسي : " الأي يلزم أن تردّ الـلام إليهه في النسبة مـا ظهرت لامسه في

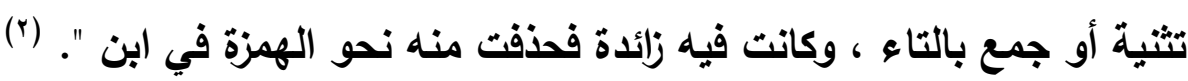

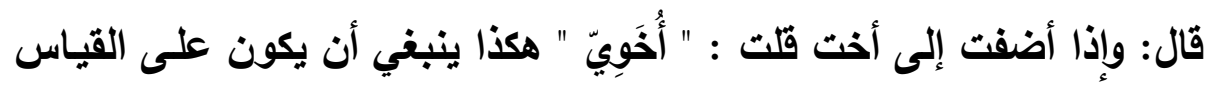

، وذا القياس وهو قول الخليل (r).

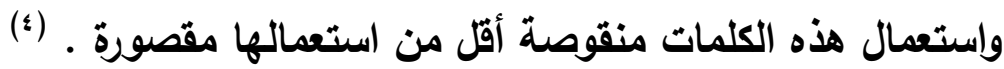

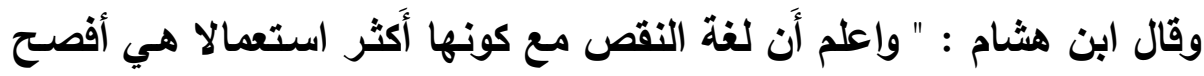

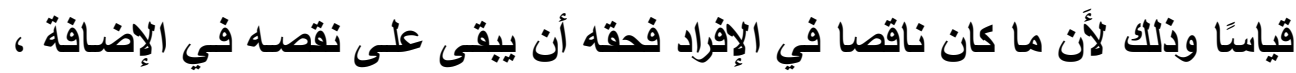

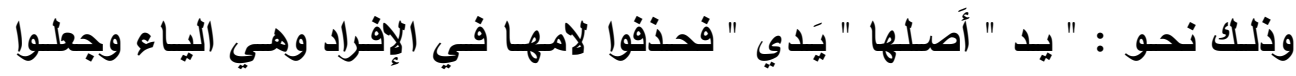
الإعراب على ما قبلها فقالوا : " هذه يد " ، ثَُّّ لما أضافوها أبقوها محذوفة التلام قال لهال

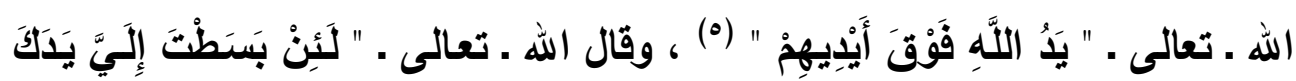

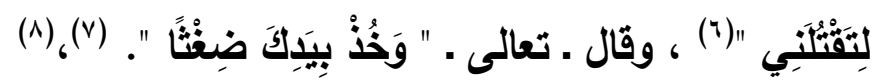

\section{الإقابل}

ويقابل النقص هنا التمام ، والقصر •

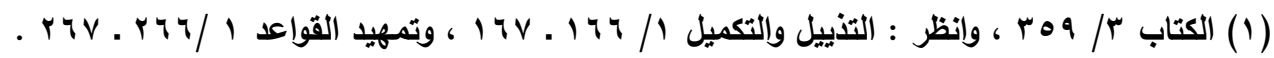

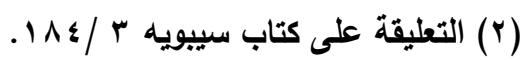

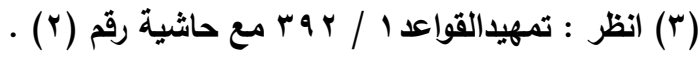

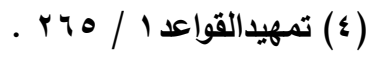

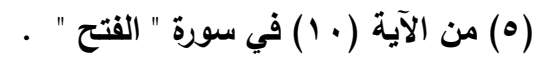

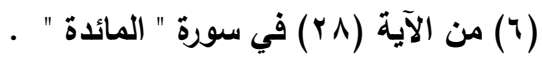

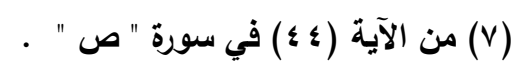
(^) 
• فالتمـام هو الاستعمال المشهور، وهو إعرابها بالحروف ، فتكون في حالة الرفع بالواو ، وفي حالة النصب بالألف ، وفي حالة الجر بالياء ، فيقال : " أبوك كريم ، وأكرم أباك ، وأحسن إلى أمك وأبيك " وهكذا بقية هذه الأسماء . وإنما سميت هذه اللغة " لغة التمام " ؛ لأن كلمـة " أب " على حرفين فقط ، والأسماء المعربة في اللغة تبدأ بثلاثة أحرف ، فإذا انضم إلى هذين الحرفين الواو أو الألف أو الياء في الإعراب فقد تمت الكلمة وكملت بهذه الحروف .

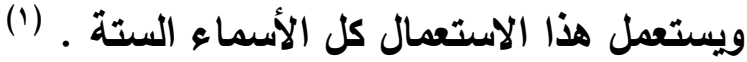
قال ابن هشام : " " الهن " يخالف " الأَب ، والأَخ ، والحم " من جهة أنها إذا أفردت نقصت أواخرها وصارت على حرفين ، وإذا أضيفت تمت فصارت على ثلاثة أحرف ، تقول : " هذا أب " بحذف اللام وأصله " أبو " فإذا أضفته قلت " هذا أَبوك " وكذا الباقي ، وأما " الهن " فإذا استعمل مفردًا نقص ، وإذا أضيف بقي في اللغة الفصحى على نقصه تقول : " هذا هن " ، و" هذا هنك " فَيكون في الإفراد والإضافة

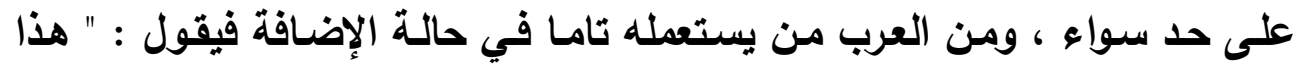
هنوك " ، " ورأيت هناك " ، و" مررت بهنيك " وهي لغة قليلة ولقتلها لم يطلع عليها الفراء ولا أبو القاسم الزجاجي فادعيا ان الأَسماء المعربـة بـالصروف خمسـة لا ستة

(1) الفصيح في " هن " أن يعرب بالحركات الظاهرة على النون ولا يكون في آخره حرف علة ، والإتمام جائز لكنه قليل جدا مثل : " هذا هنوه ، ورأيت هناه ، ونظرت إلى هنيه " ، وأنكر

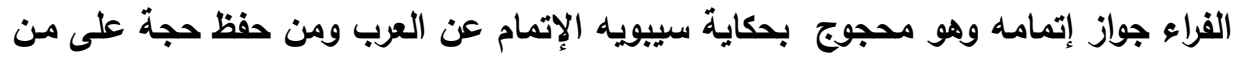
لم يحفظ

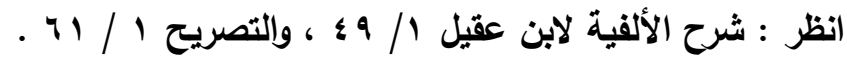

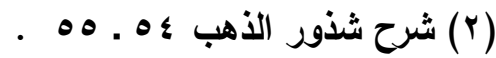


• والقصر : هو التزام الألف مطلقًا ، وجعل الإعراب بالحركات المقدّرة على

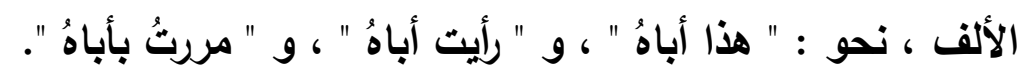
ويكون بإلزامها الألف دائما رفعًا ونصبًا وجرًا، فهي اسم مقصور تقدر عليه

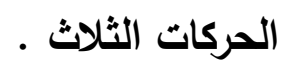

والذي يستعمل هذا الاستعمال ثثلاثة أسماء هي " أب ، وأخ ، وحم ".

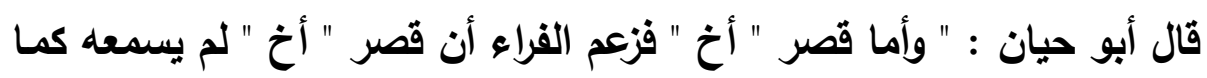
سمعه في " أب " ، وأجـاز ذلك هثـام ، أجاز: " جاءني ومررت بأخاك " وحكي " مُكْرَهُ أخاكَ لا بطل " (")، وأنثثد المصنف في الثرح مستدلا على قصر الأخ :

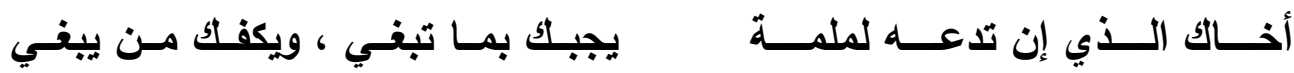

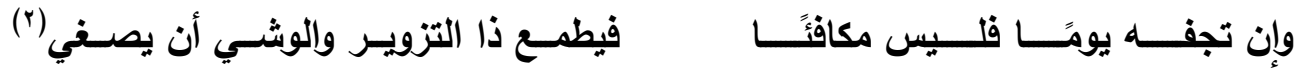
ولا دليلـ فيـه لأنـه يحتمـل أن يكون منصـويًا بإضمار فعل ، التقدير : " الززم

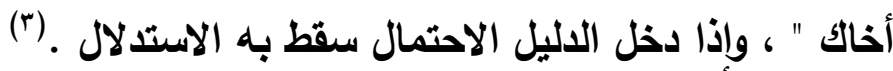
وقال ابن هشام : " وقصرهن أولى من نقصهن كقوله :

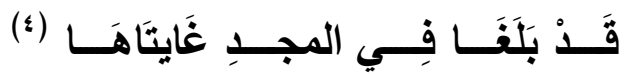

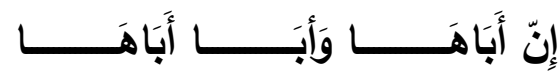

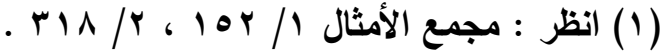

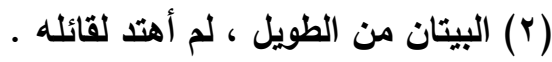

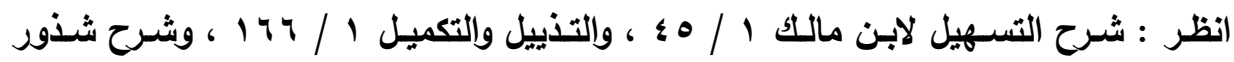

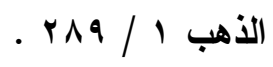

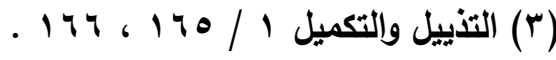
(؛) رجز ، نسب لروئة ، وهو في ملحقات ديوانه 11 ، ، كما نسب لأبي النجم ، ولرجل من بنـي

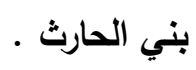

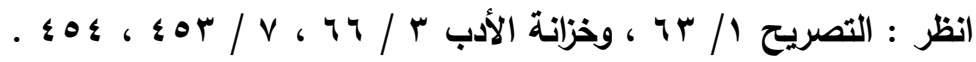


وقول بعضهم : " مُكْرَهُ أخالك لا بطل " (1)، وقولهم للمرأة " حماة ". (ץ) قال ابن مالك :

والــنقص فــي هــأ الأخيــر أحسـن

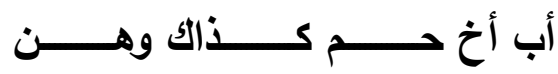

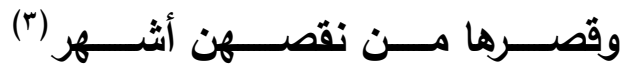

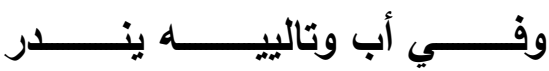

ب ـ النقصان في باب المعرفة والنكرة الناقص من المعارف هو الموصولات .

(1 ) مَثَلّْ روي هكذا في كتب النحو .

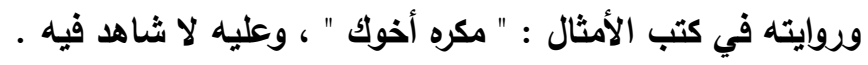

ويضرب لمن يحمل على ما ليس من شأنه .

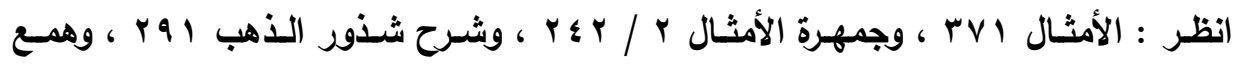

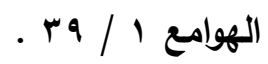

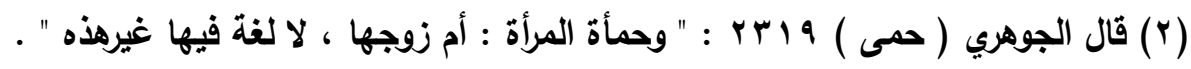

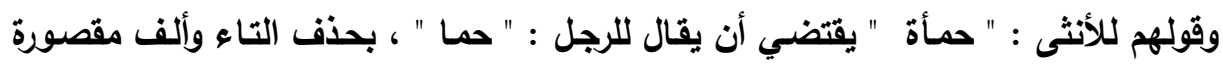

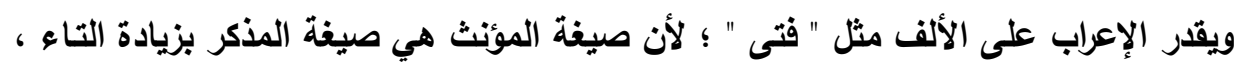
ومن ذلك قول الراجز :

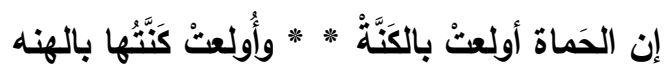

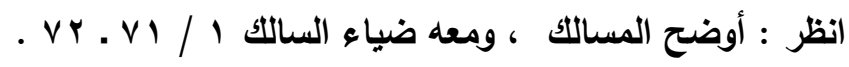

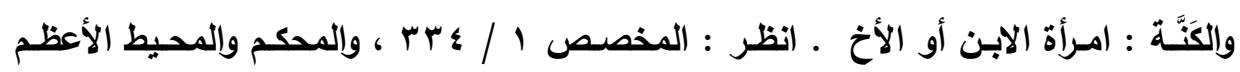

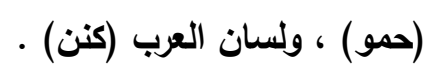

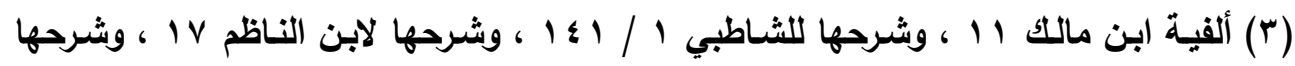


والمعرفة : هي ما وضـع لثـيء بعينها ، والمعرفة الناقصة هي التي تحتـاج

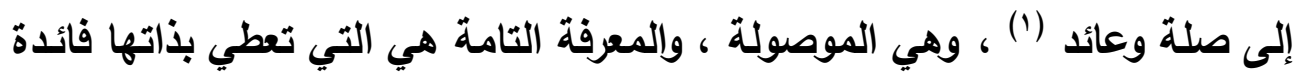
، دون أن تحتاج إلى ما يكملها .

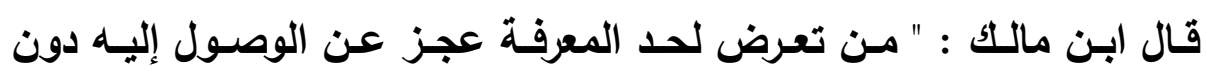

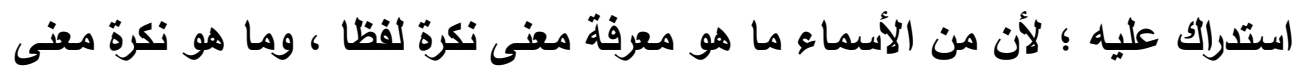
معرفة لفظا ، وما هو في استعمالهم على وجهين " (†).

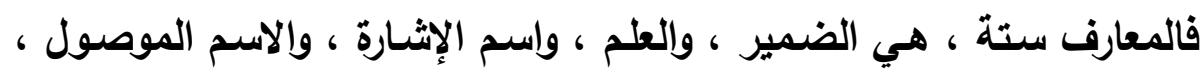

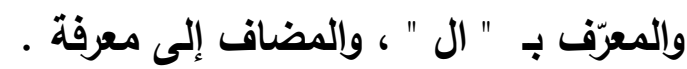

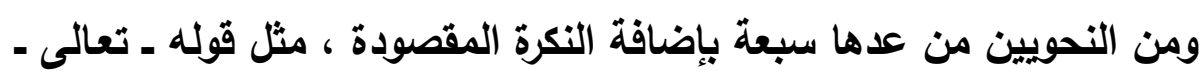

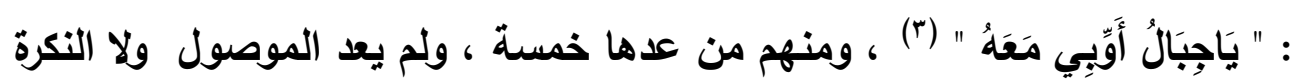

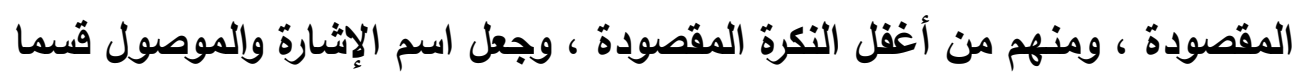

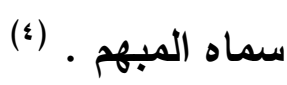
ومسن هـذه المعـارف مـا هـو مـبهم وهـو الضـمير ، واسسم الإثــارة ، والاسـم الموصول .

قال ابن الخشاب : " وأما كونها مبهمة مـع كونها معارف فهو أنها لا يشار

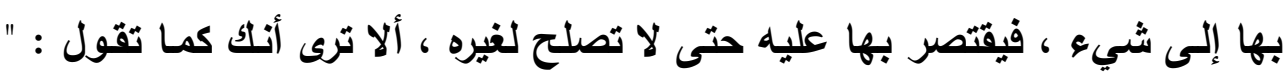

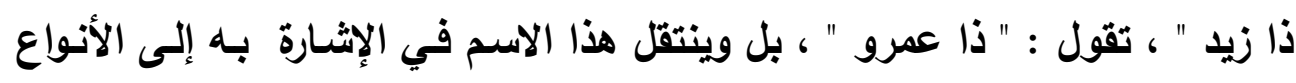

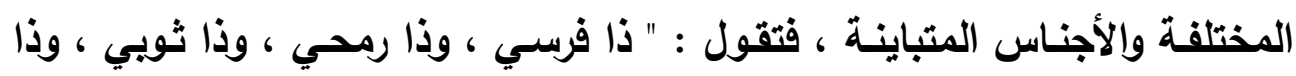

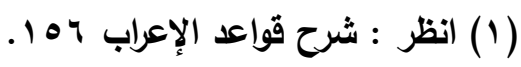

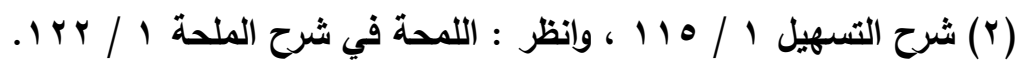

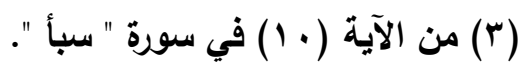

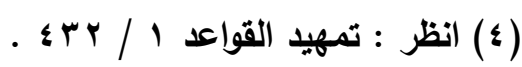


عملي ، وذا أكلي ، وذا شربي ، وذي حركتي ، وذا سكوني " ، فيقع اسم الإثـارة

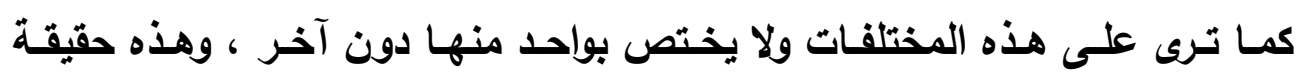

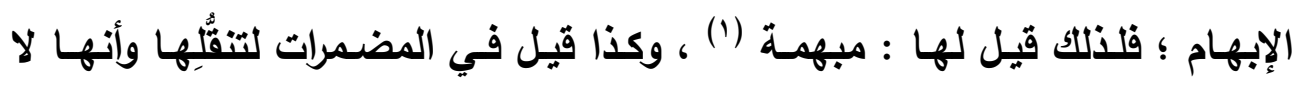

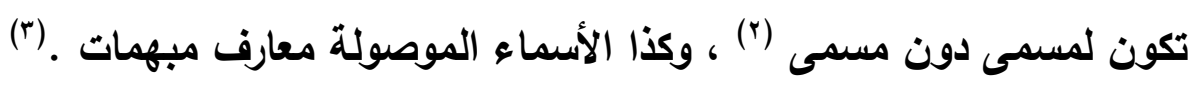

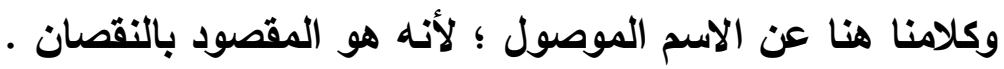

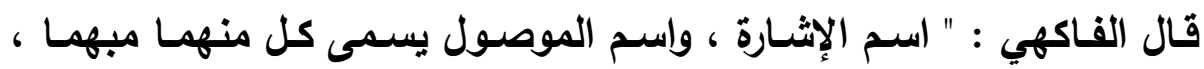

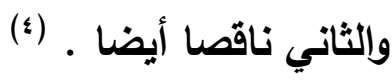

والموصسول ضرب من المبهمات لوقوعـه على كل شـيء من حيوان وجمـاد

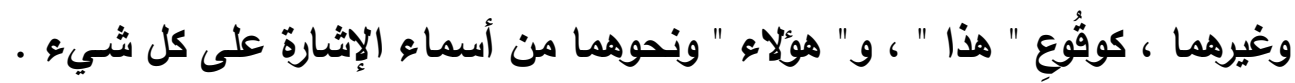

وهو عبارة عن الكلمة التي تفتقر ـ في دلالتها على مغنى الاسم التام ـ إلى مـا

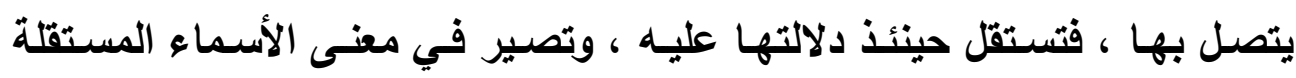

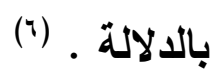
قال ابن الخباز : " حد الموصول : ما لابد له في تمامه اسمًا من جملة يشفع الأله

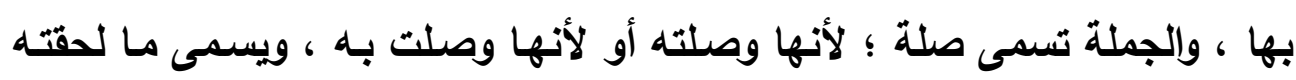

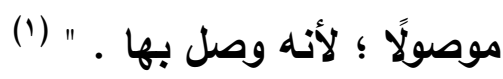

(1) ويزول هذا الإبهام باسم الجنس المشار إليه .

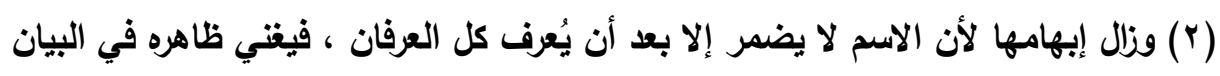

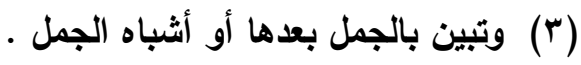

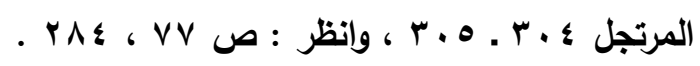

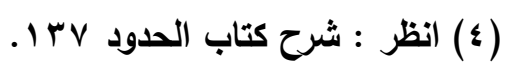

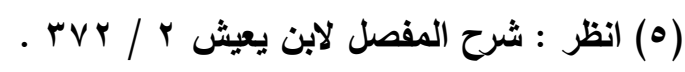

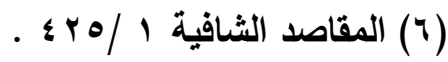




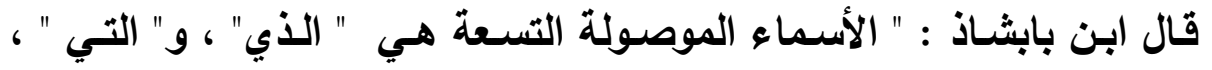

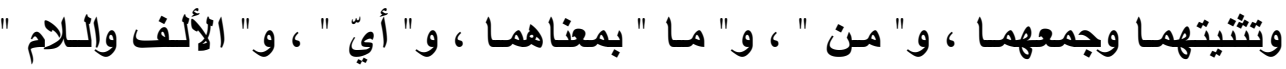

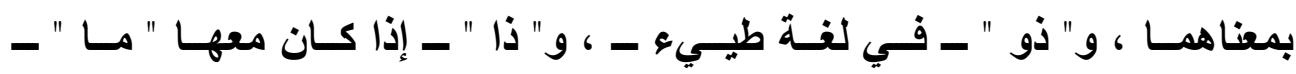

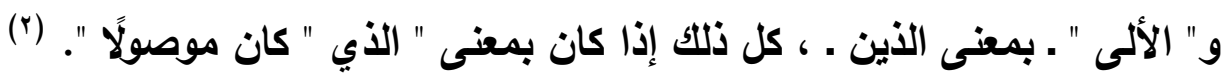

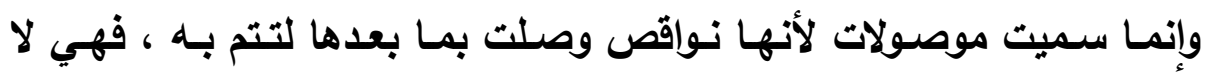

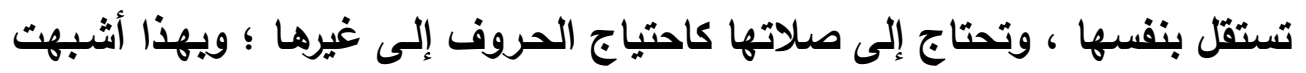

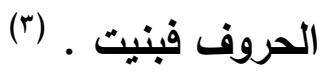

وقيل : إن سبب البناء أنها باحتياجها لما بعدها صـارت كبعض كلمـة ، كما

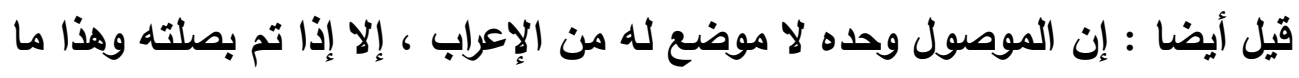

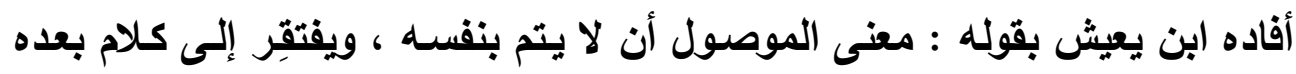

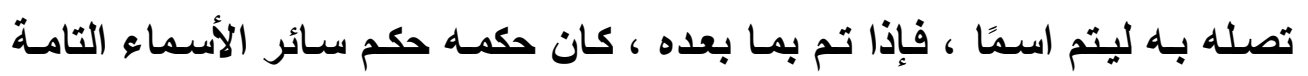

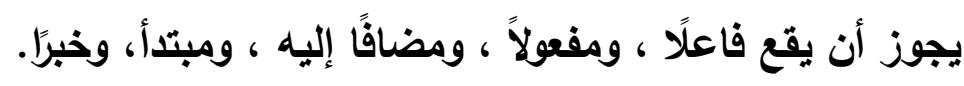

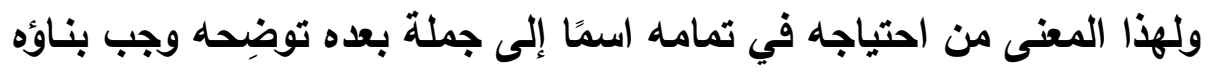

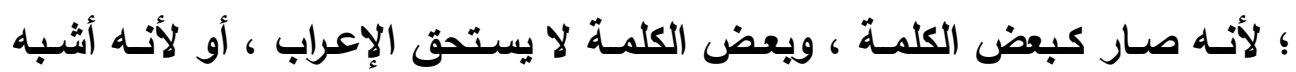

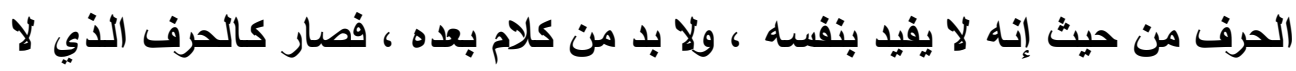

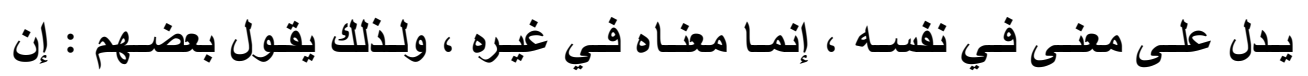

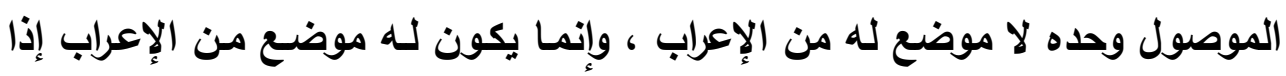
تم بصلته . 
والصـواب عنــي أن الإعـراب للاسـم الأول الموصـول ، ومجـرَى الصـلة مـن

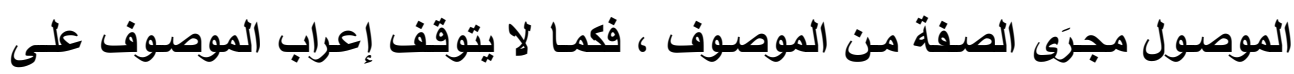

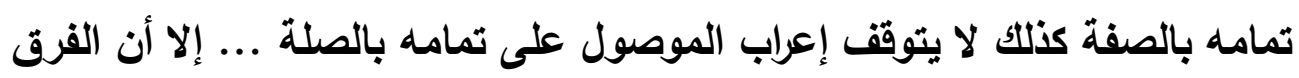

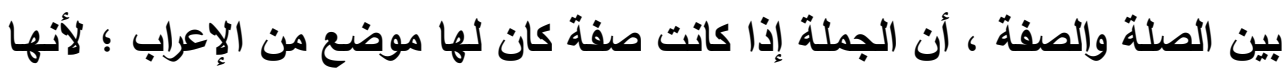

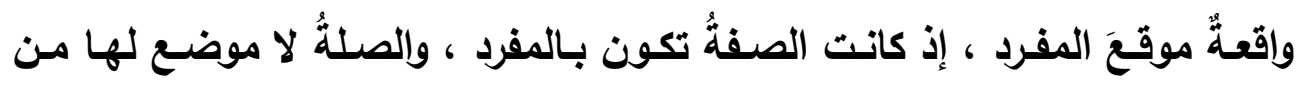

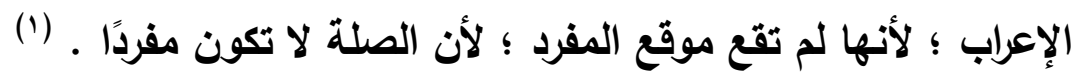

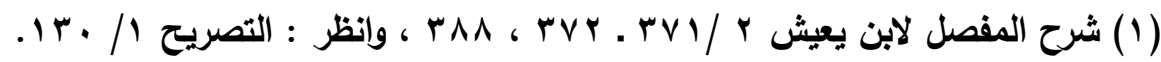




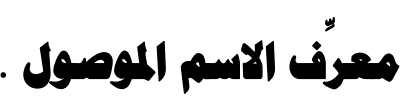

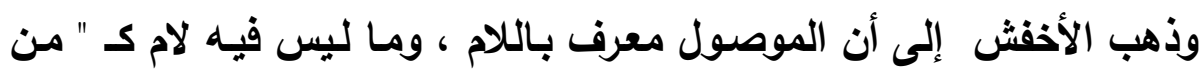

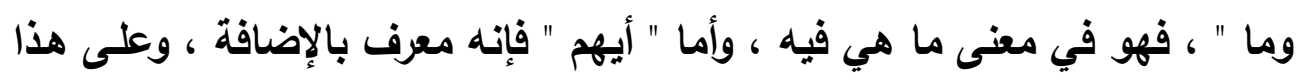

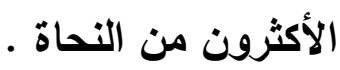

وعلى هذا يكون الموصول من قبيل المعرف باللام ، وليس قسما مستقلا من

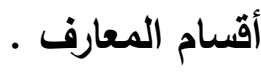

وذهب الفارسي إلى أن تعريفه بالعها الذي في الصلة ، فقال : " وهكذا ينبغي

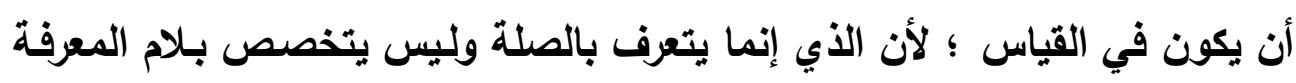

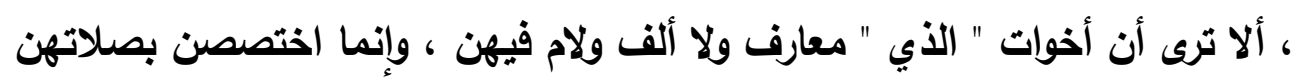

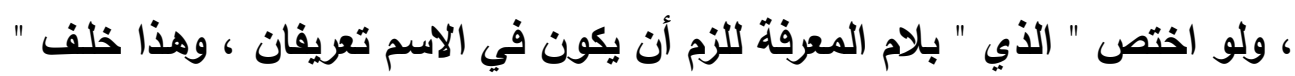

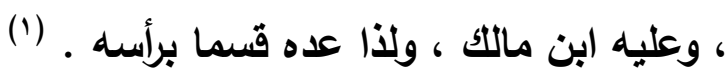

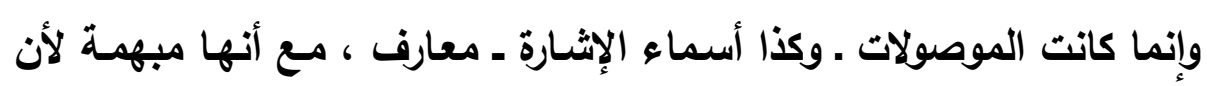

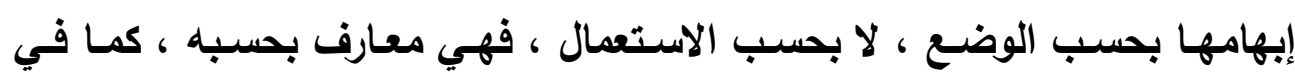

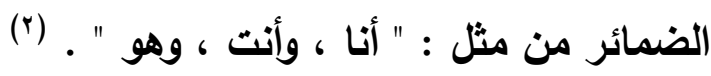

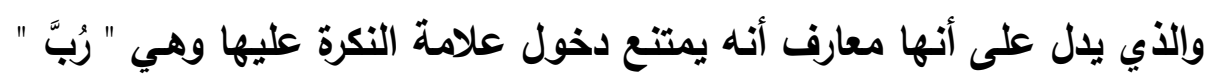
، وأنها توصف بالمعارف ، مثال" جاغني الذي عندك العاقلُ " ، وتقع أيضًا وصفًا للمعارف نحو" جاغني الرجل الذي عندك " . .

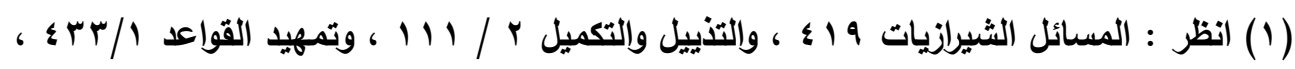

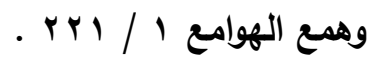

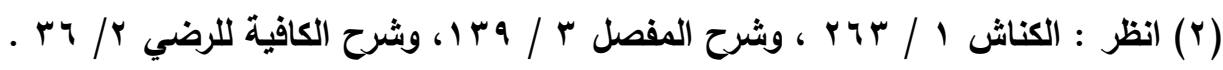




\section{المقابل}

ويقابل المعرفة الناقصة هنا المعرفة التامة ، وهي بقية المعارف .

والمتفق عليه أن لفظ الجلالة وضميره أعرف المعارف ، ثم اتسع خلافهم بعد

ذلك في أعرفها ، وقد أجمل ذلك المرادي في قوله : " وأعرفها المضمر على الأصسح ، ثم العلم ، ثم اسم الإشارة ، ثم الموصول ، ثم ذو الأداة ، وقيل : هما في مرتبة واحدة ، وقيل : ذو الأداة أعرف من الموصـول ، والمضـاف إلى واحد منها في مرتبته مطلقا على لأي المصنف إلا المضاف إلى المضمر فإنه في مرتبة العلم على ألى

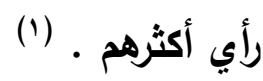

و قال ناظر الجيش : " ما من شيء من المعارف المذكورة إلا قيل إنه أعرف

من بقيتها إلا المضاف ، وسببه أن المضاف إنما يكتسب التعريف من الذي أضيف

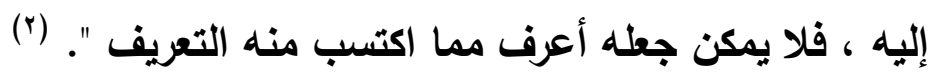
وقد نسب أبو حيان لأبي محمد بن حزم أنه ذهب إلى أنها لا تتفاوت ، وكلها

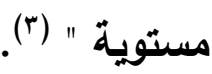

والمراد بقولهم : " إن هذا أعرف من هذا " أن تطرق الاحتمـال إليه أقل من

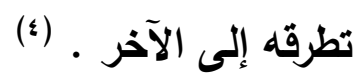

• الضمير نحو : أنا ، وأنت ، وهو ، والكاف في رأيتك ويك ...

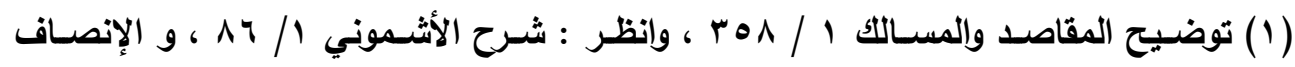

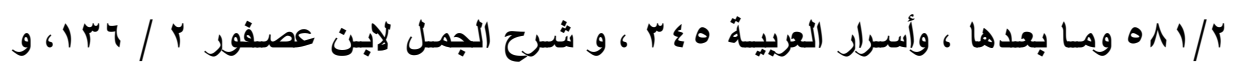

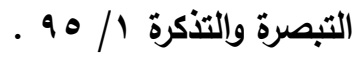

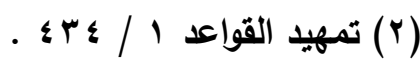

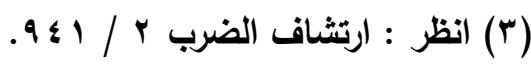

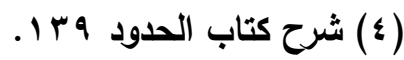


(1) والمضمر من المعارف التي لا يصح تنكيرها . والضمير أعرف المعارف ؛ ولذلك لا يوصف ولا يوصف به ، في حين أن غيره

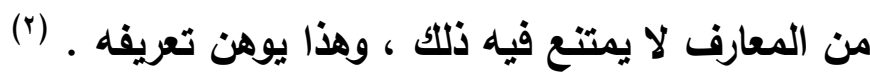
وأعرف الضمائر ضمير المتكلم ، ثم المخاطب ، ثم الغائب . (广) • العلم وهو كل لفظ عُلِّق على مسمى ، فجعل ذللك اللفظ علامـة لـه ينفرد بها

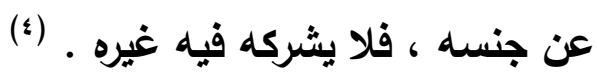
والعلم معرفة بالوضع لا بالأداة ، والأصل أن يكون للأعيان ـ أي الجثث ـ (•) (0) ك " زيا وهند " ـ في أسماء الأناسي ـ و" لاحق ، والوجيه " ـ في أسماء الخيل .

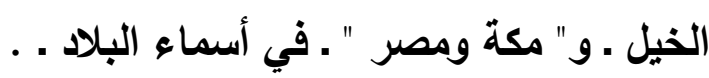
وجـاء في المعـاني قليلا ، كقولهم في لفظة التنزيـه والتبرئة : " سبحان "، وذلك في قول الأعشى :

(1) فأما دخول " رب " عليه في قولهم : " ريه رجلا " ـ مع أنها لا تدخل إلا على النكرات ـ فلأنـه

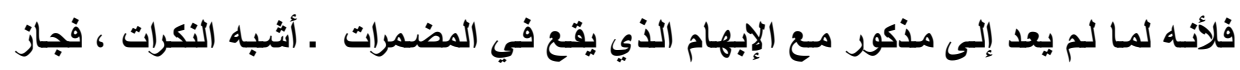

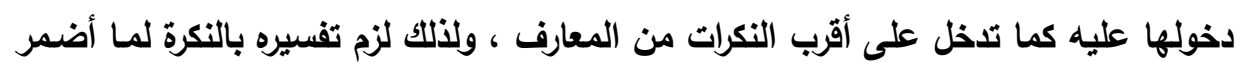

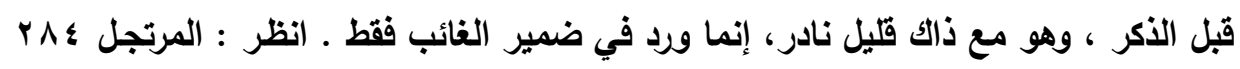

$$
\begin{aligned}
& \text {. rAo. }
\end{aligned}
$$

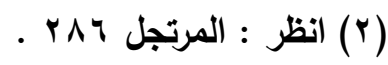

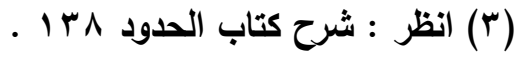

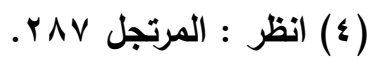

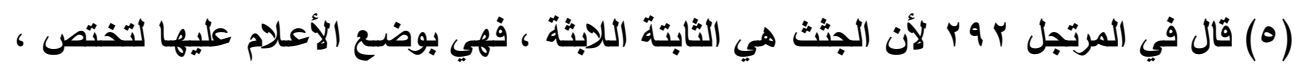

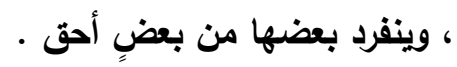




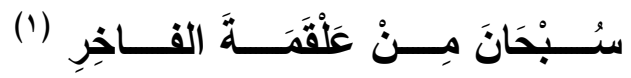

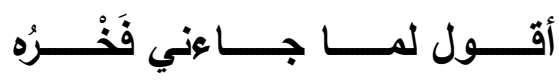
وذهب أبو علي في قول الفرزدق :

بهــا جـرب عـــت علــي بزويــرا (r) وإن قـال غـاوٍ مسن تنـوخ قصـيدةً إلى أن " زويرا " اسمُم علمُّم في هذا البيت ، علقه الثـاعر على القصيدة فلم

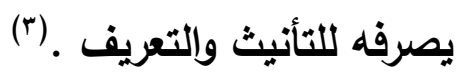
وأقوى الأعلام أسماء الأماكن ، لقلة الاشتراك فيها ، ثم أسماء الناس ، ثم

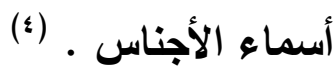

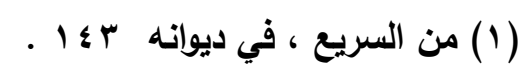

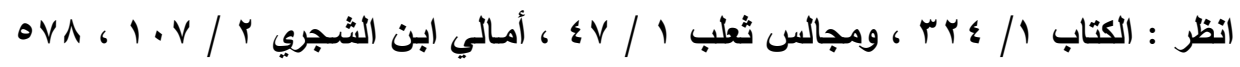

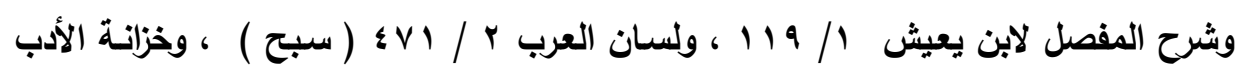

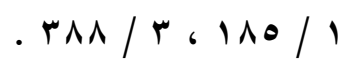

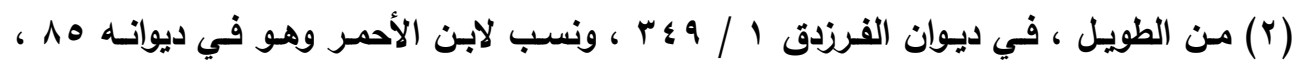

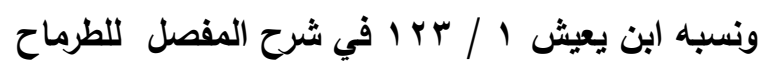

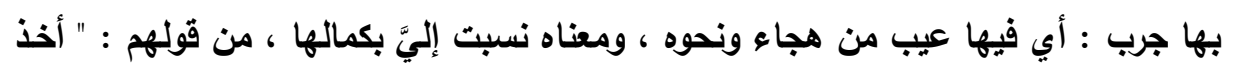

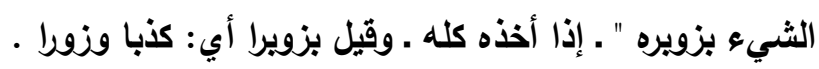

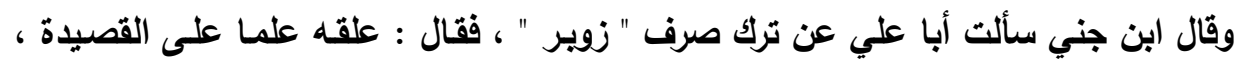
فاجتمع فيه التعريف والتأنيث .

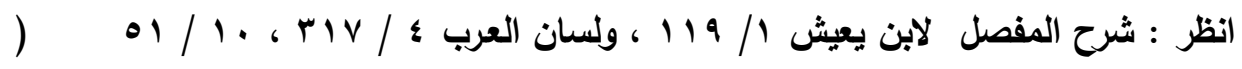

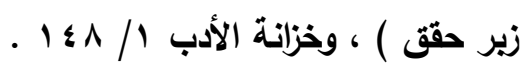

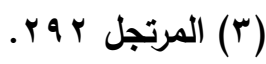

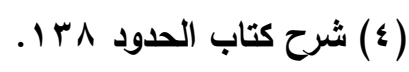


ولا يوصف العلم إلا إذا شاركه في لفظه غيره بأن أُطلق على غيره علمـا أيضًا

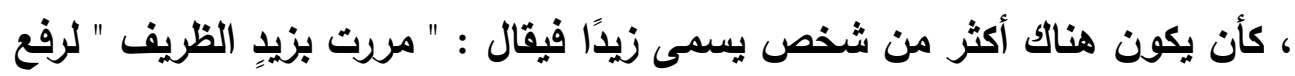

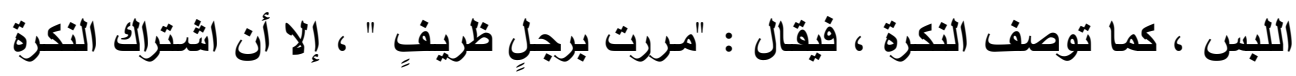

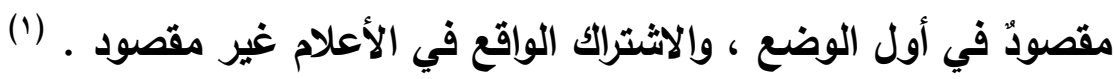

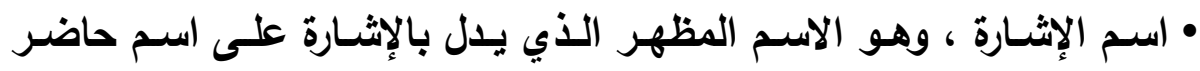

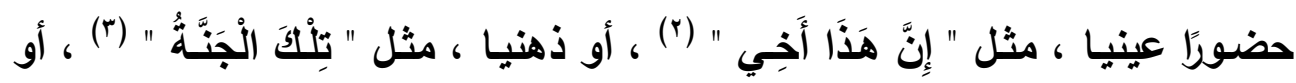

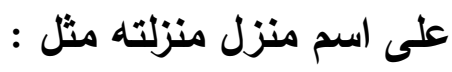

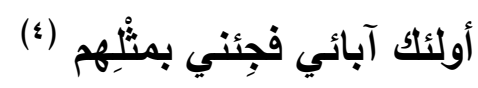

وأسماء الإشـارة : أعرفها مـا كان للقريب ، ثم للمتوسط ، ثم للبعيد . (•)

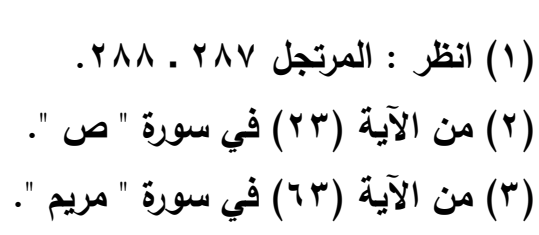

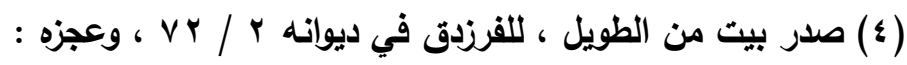

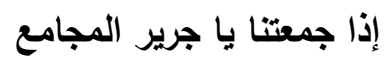

انظر : إصلاح المنطق 0 ؛ ، ومعاني القرآن وإعرابه للزجاج ؛ / ـ بـ ، وشرح كتاب الحدود . 10r

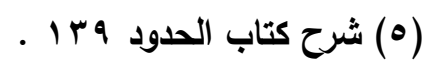


وهي مبنية لتضمنها معنى الإثارة (') ، أو لشبه الحرف (r) ، ـ كما أفاد ابن

مالاك . (r)

قال أبو حيان : " وأما سيبويه فاعتل لبنائها بشدة توغلها في الإبهام فأشبهت الحروف ، ألا ترى أن " مِنْ " تبعيض على الإطلاق وأي شـيء أردت تبعيضـه أتيت

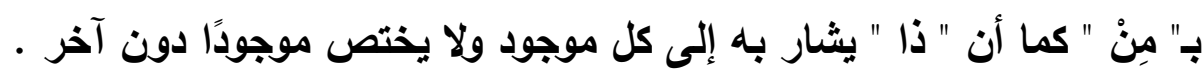

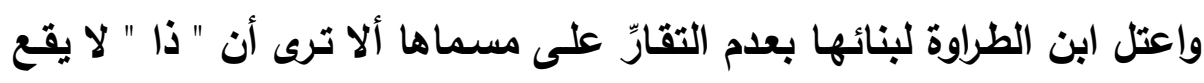

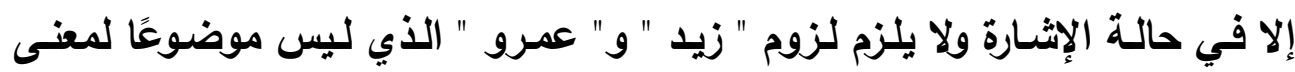

فيزول بزواله . (1)

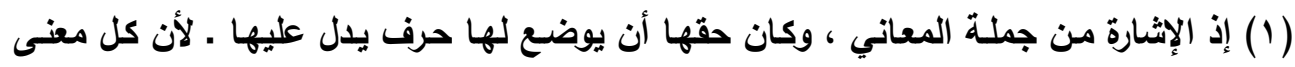
ياخل الكلمة ، أو الكلام يوضع له حرف كالاستفهام ، والتفي ، والتمني ، والترجي ، والابتداء

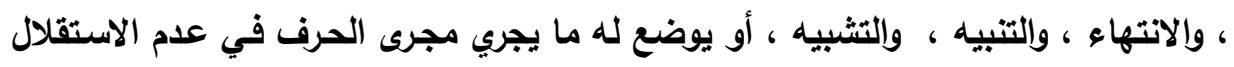

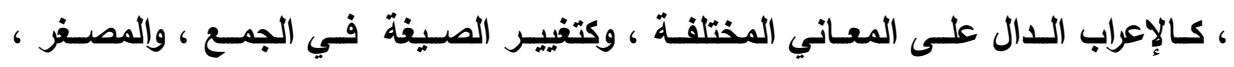

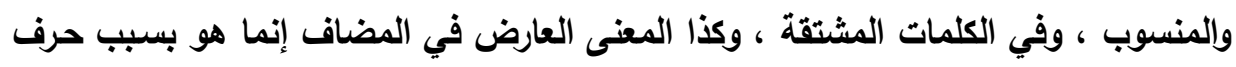

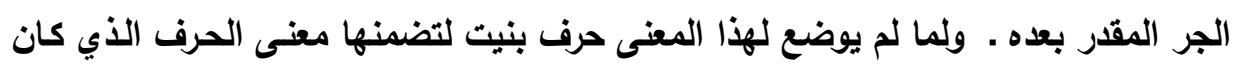

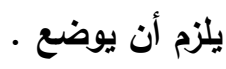

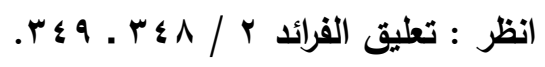

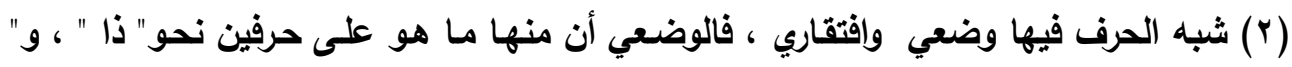

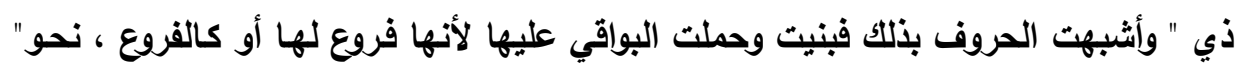

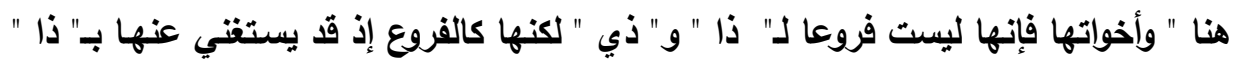

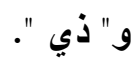

والافتقاري المراد به هنا حاجة اسم الإثارة في إبانـة مسماه إلى مواجهة أو مـا يقوم مقامها

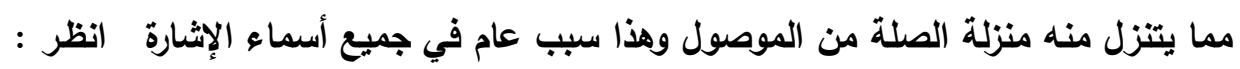

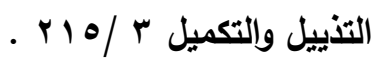

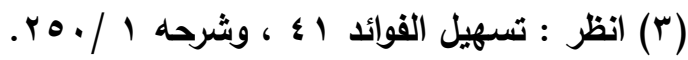


وأما " هذان " ، و " هاتان " فأشبها مثثيات الأسماء المتمكنة ، فأعريا. (؟)

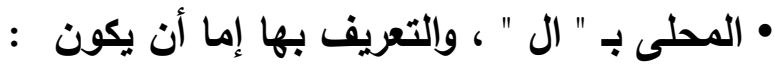

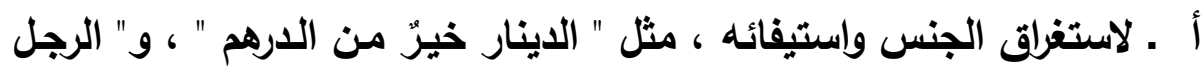

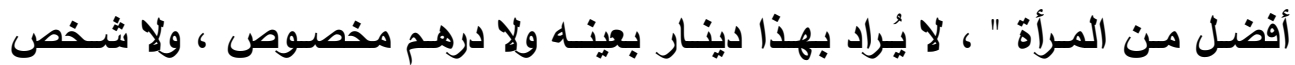
مخصوص بالتفضيل ، ولا امرأة مرادة بأنها مفضولة ، ولكن جميع الجنس .

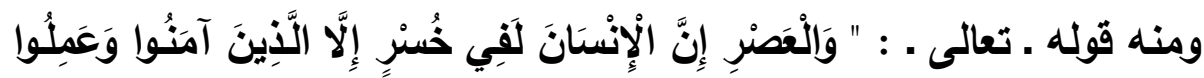

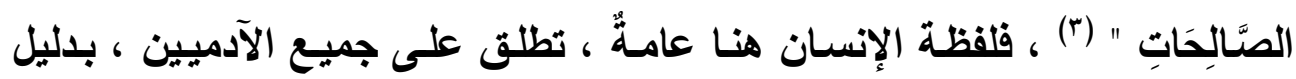

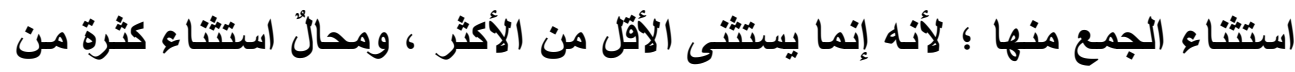

واحد . (๕) ب . أو لتعريف العهد ، كقول قائـل مثثلا : " لقيت رجـلا كريمـا أو رجـلا من شأنه كذا " ، فيقول المخاطب ـ إن عناه أمر ذلك الرجل . : " فما فعل الرجل ؟ أي المعهود بيني ويينك في الأكر أيها المتكلم ، فلابد في تعريف العهد من مذكور ومخاطَب ومخاطِب .

ومن هذا الباب كل نكرة تصدرت في أول خطاب ثم أعيدت بعينها ، فإنها

تعرف بلام التعريف لئلا توهم بأنها غير تلك المذكورة . (0) وللعلماء في تعيين المعرِّف هنا أربعة مذاهب : اـ ذهب الخليل إلى أنه " ال " والألف أصلية ، لا زائدة .

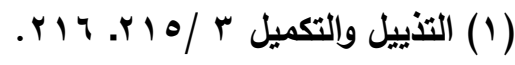
(Y) وقيل : إن " هذان " و " هاتان " صيغتان مرتجلتان للرفع ، و" هذين " و هاتين " صيغتان

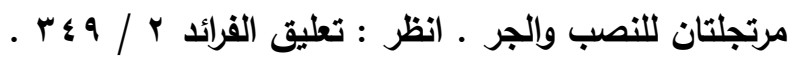

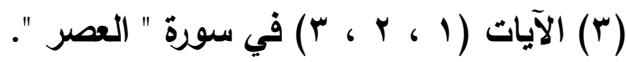

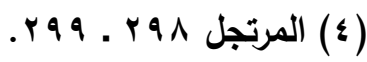

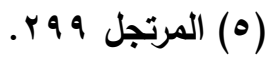




$$
\text { r ـ ـ ذهب سبيويه إلى أنه " ال " ، والألف زائدة . }
$$

r ـ ذهب المبرد إلى أنـه الألف وحدها والـلام زائدة فرقا بين همزة الاستفهام واللهزة المعرفة .

ع ـ نسب إلى كثير من النحويين أن المعرف هو اللام وحدها. (1) والأعرف فيه ما كاتت فيه " ال " للحضور، ثم للعهد الشخصي ، ثم للجنسي

قال اللدماميني : " وقد تخلفها " أم " في لغة حمير ونفر من طيء ، وفي

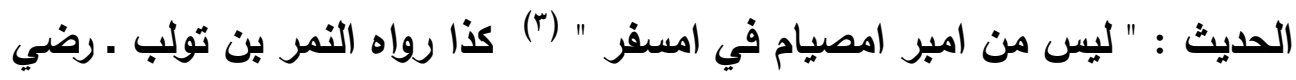

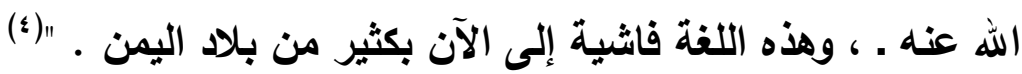

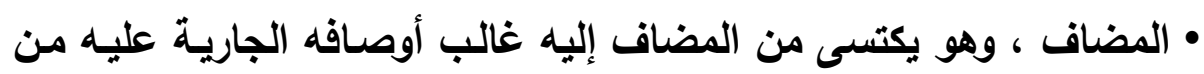
التعريـف ، والتتكير ، والتخصيص ، والاستفهام ، والثـرط ، والبنـاء ، والتذكير ، والتأنيث

قال ناظر الجيش : " وأما المضاف إلى أحدها قفيه ثلاثة مذاهب : أحدها : أن ما أضيف إلى شيء فهو في رتبة ذلك الشيء ، وهو رأي جماعة ، منهم المصنف . (0)

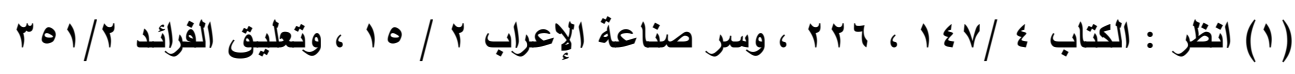

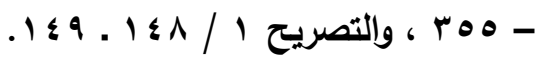

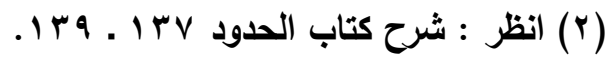

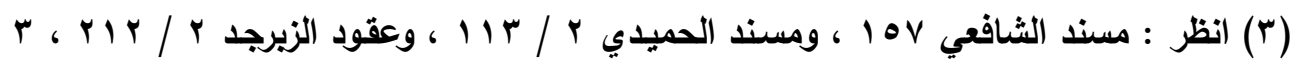

$$
\text { . I^r/ }
$$

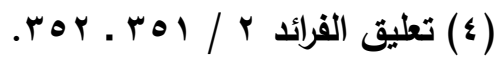

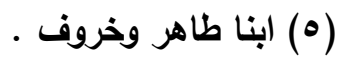


الثاني : أن مـا أضيف إلى شـيء فهو دون مـا أضيف إليه في الرتبة وهو

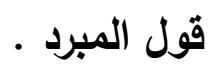

الثالث : التفصيل وهو إن أضيف إلى غير المضـمر فهو في رتبته ، وإن أضيف إلى المضمر فهو في رتبة العلم .

\section{وذكر ابن عصفور أنه مذهب سييويه . (1)}

وقال ابن هشام : " المضاف لمعرفة وهو في درجة مـا أضيف إليه فـ " غلام

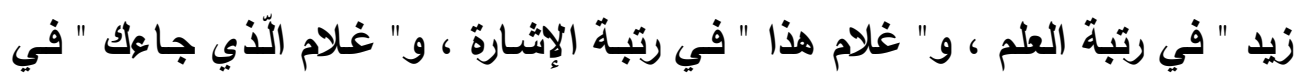

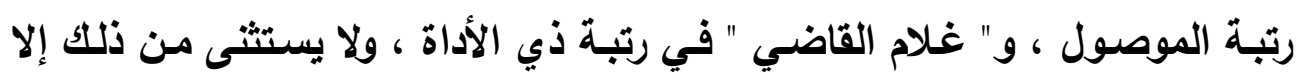

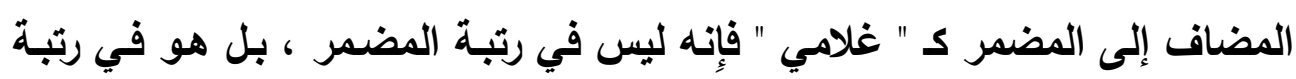

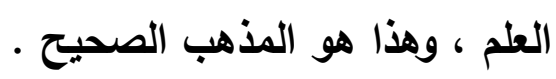

وزعم بعضهم أَن ما أضيف إلى معرفة فهو في رتبة ما تحت تلك المعرفة

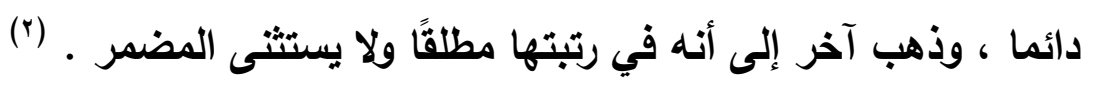

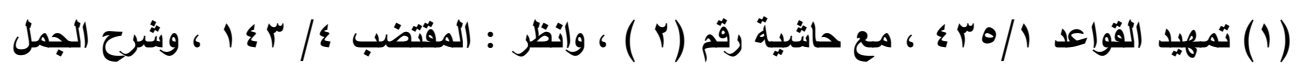

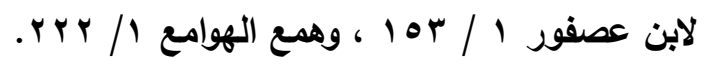

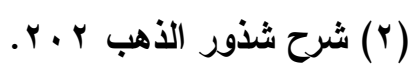




$$
\text { ج ـ الناقص في باب النواسخ }
$$

قال ابن الحاجب : الأفعال الثّاقصة ما وضع لتقرير الفاعل على صفة (') . وذهب الجمهور إلى أنها سميت ناقصة ؛ لعدم اكتفائها بالمرفوع (†) ، بل لابد

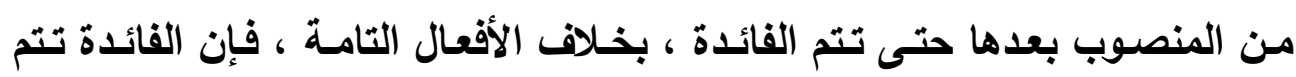

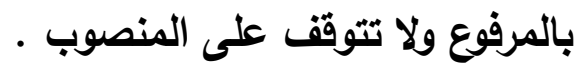
قال في شرح التسهيل : " وإنما لم تكتف بمرفوع ؛ لأن حدثها مقصود إسناده

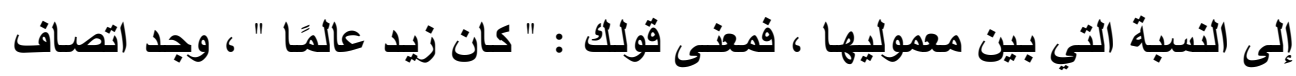

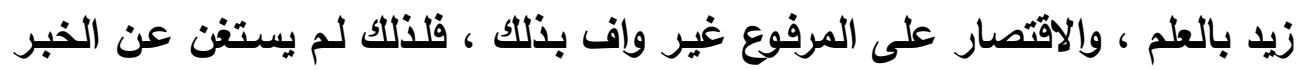

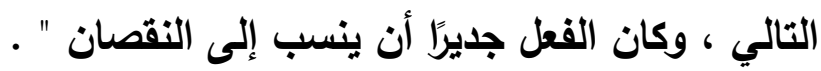

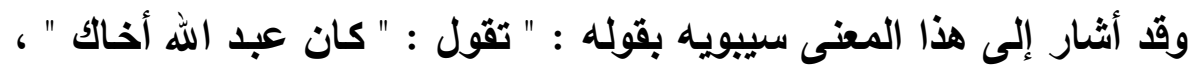

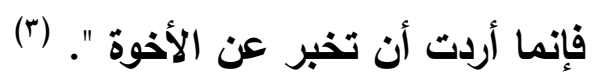

فبيّن أن " كان " مسندة إلى النسبة ، فمن ثمّ بينا عدم الاكتفاء بالمرفوع " .

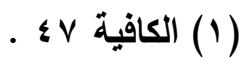

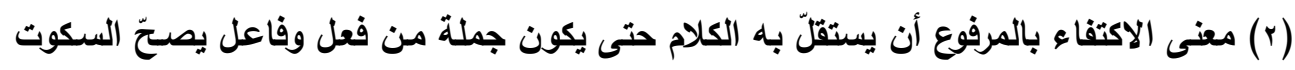

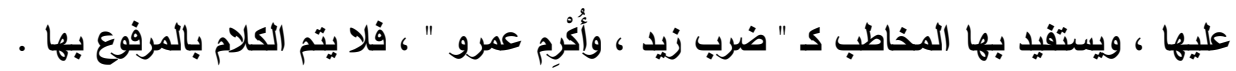

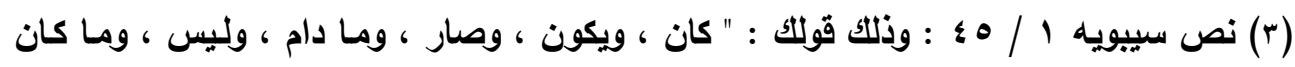

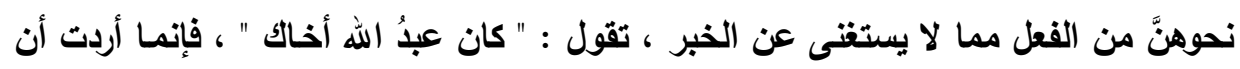

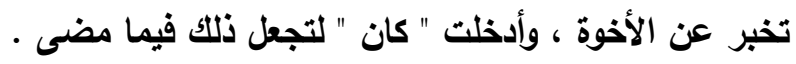

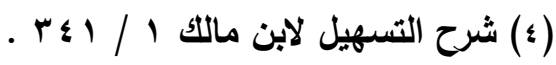


وذهـب المبـرد ، وابـن السـراج ، والفارسـي ، وابـن جنـي ، وابـن برهـان ،

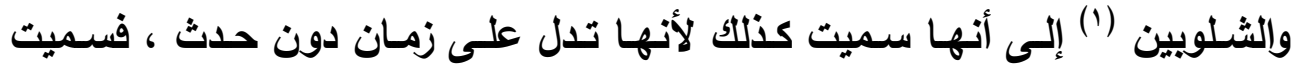

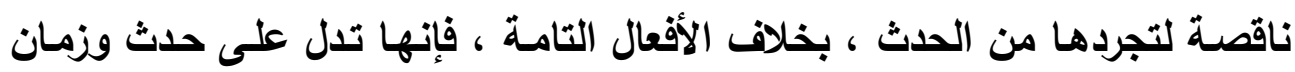

قال ابن يعيش : " وتسمى أفعالًا ناقصة ، وأفعال عبارة ، فأما كونها أفعالا ،

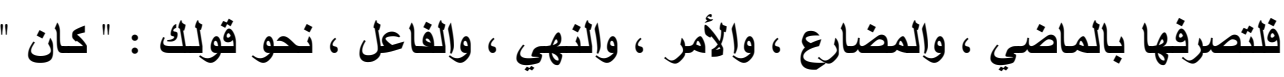
، " يكون " ، " كن " ، " لا تكن " ، و " هو كائن " .

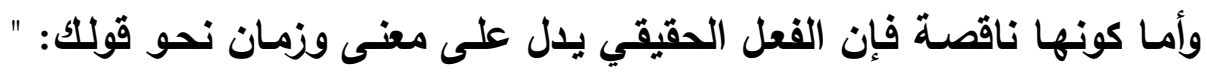
ضَرَبَ " فإنها يدل على ما مضى من الزمان ، وعلى معنى الضرب ، و " كان " إنمـا

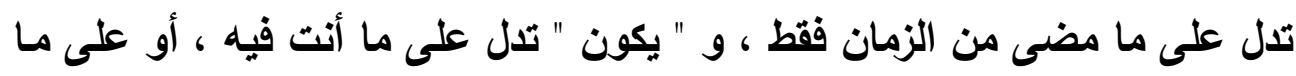

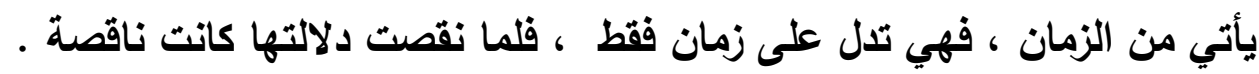

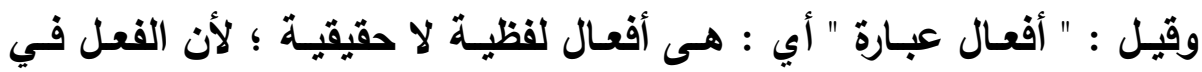

الحقيقة مـا دل على حدث ، والحدث الفعل الحقيقي ، فكأنـه سُمتّى باسم مدلولهيه ،

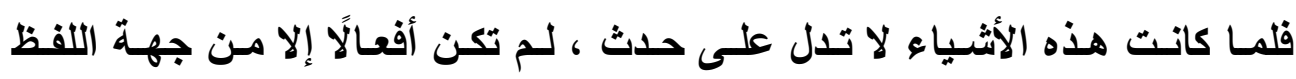

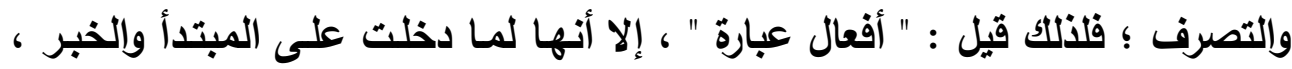
وأفادت الزمان في الخبر ، صار الخبر كالعوض من الحدث ، فلذلك لا تلتم الفائدة

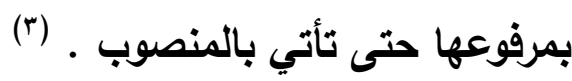

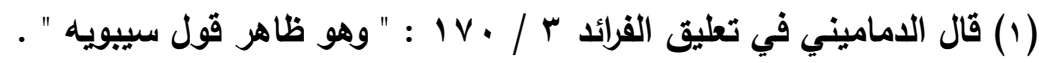

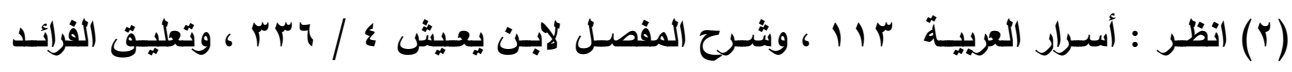
$.1 \mathrm{~V} \cdot / \mathrm{r}$

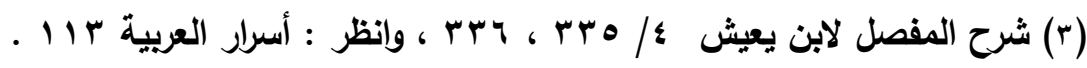


قال الثاطبي : " والناظم ـ يقصد ابن مالك ـ لم يرتضِ هذا الرأي من تجردها

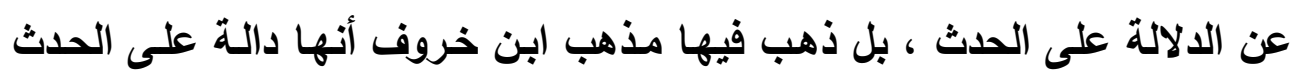

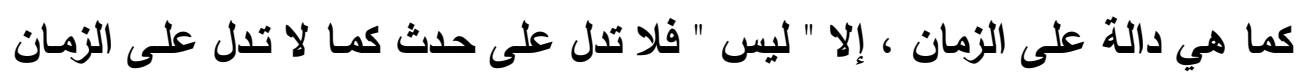

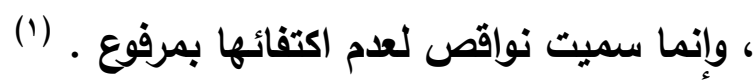

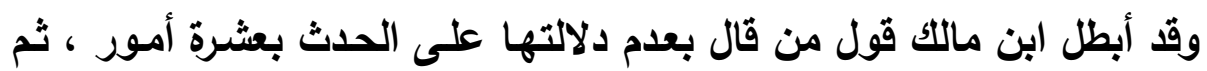

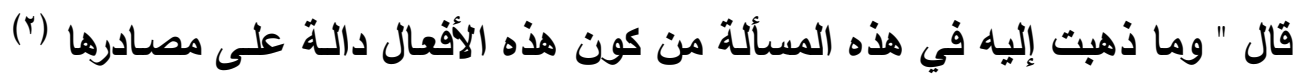

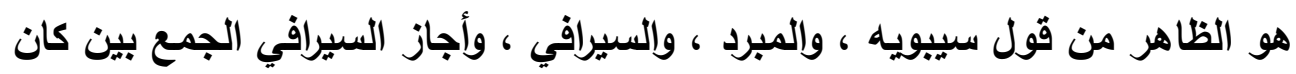

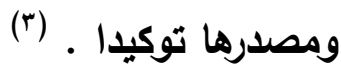
و" كان " وأخواتها أفعال ناقصة ، إلا " فَتِى " ، ، و" ليس " ، و" نال " إن كان

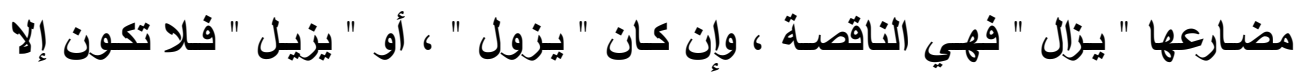

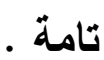
والناقص من هذه الأفعال وإن كان يدخل على المبتأ والخبر ، إلا أنه لا ياخل

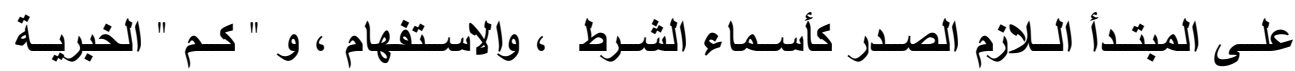

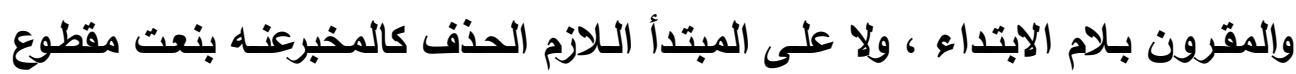

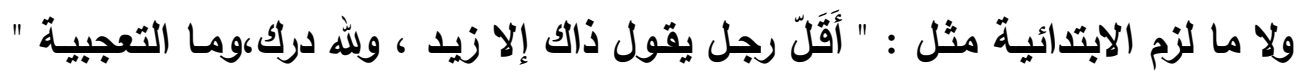

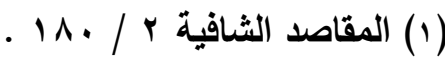

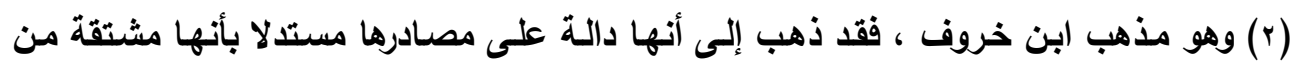

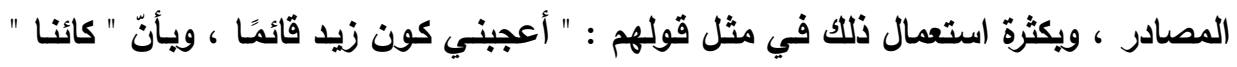

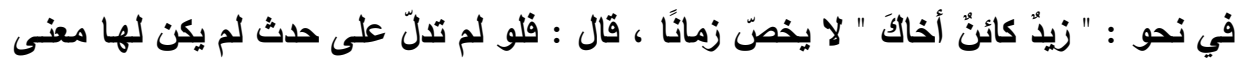

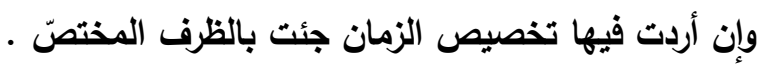

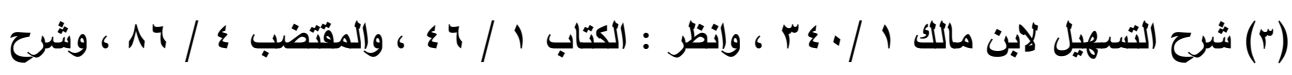

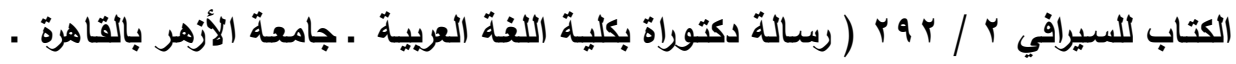
تحقيق د / دردير محمد أبو السعود ) . 
ولا ممـا لزم عدم التصرف كـ " ايمن " في القسم وطويي للمؤمن ، وويل للكافر

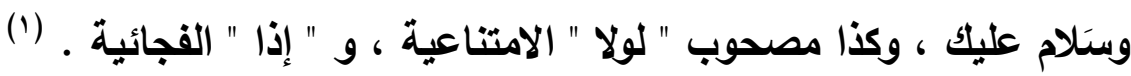

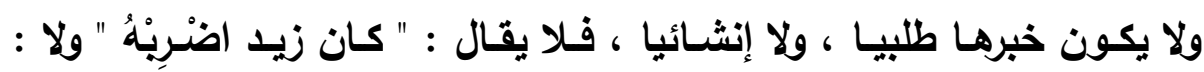

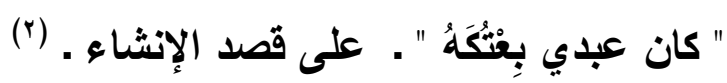

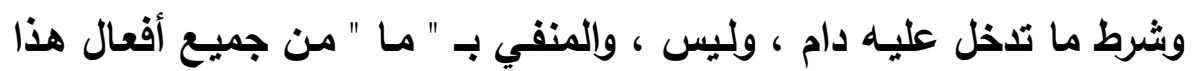

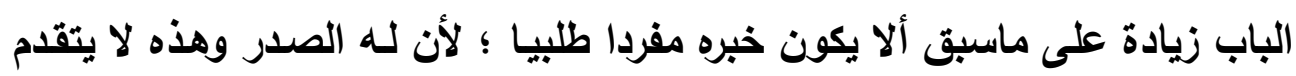

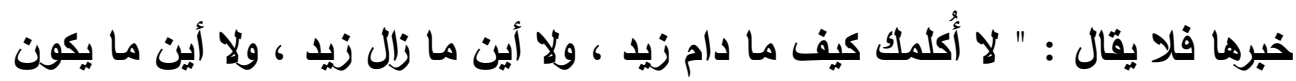

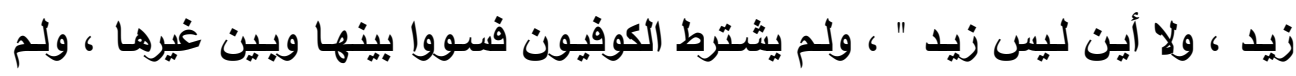

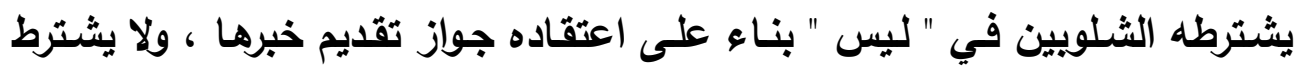

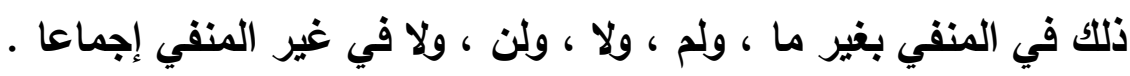

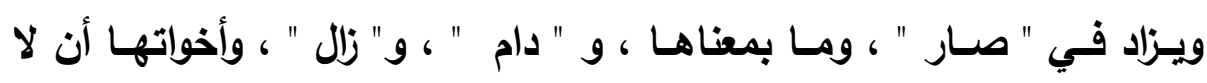

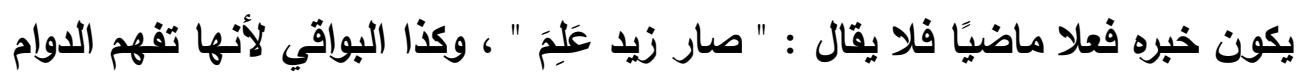

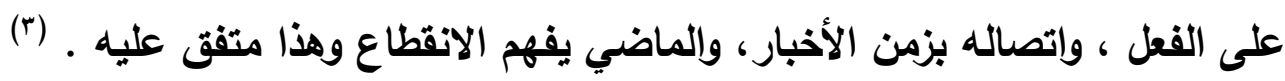

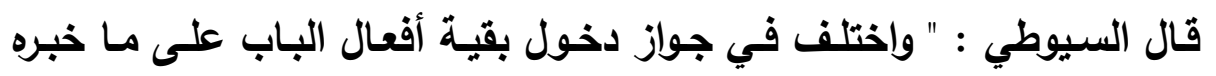

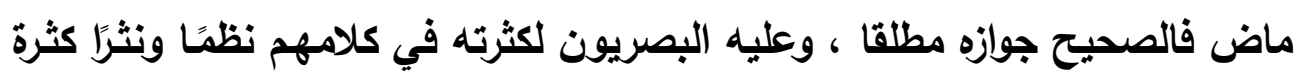

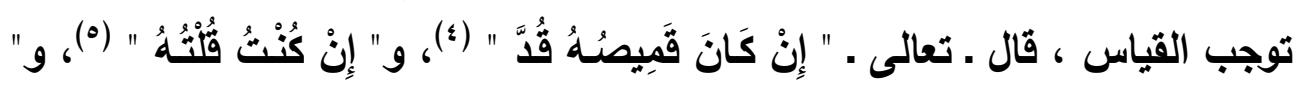

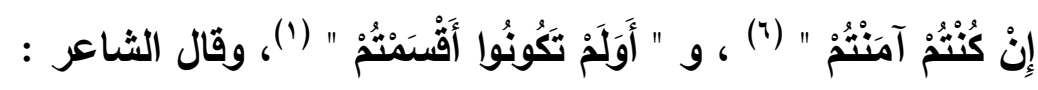

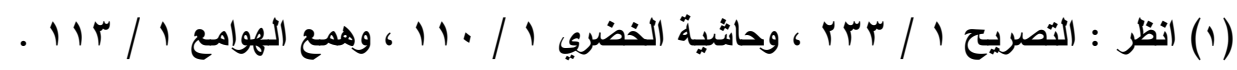

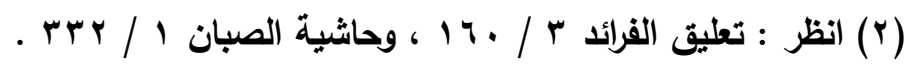

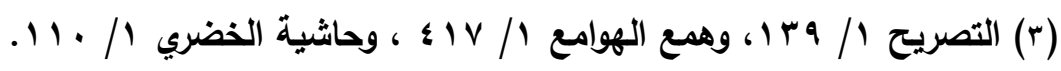

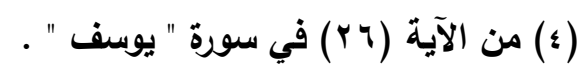

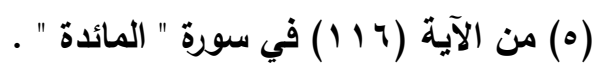

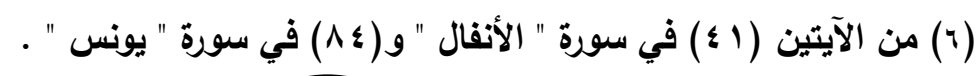




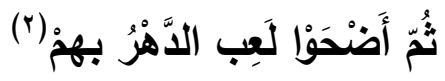

وقا كانوا فأمسى الحيٌّ سنَارُوا(")

وحكى الكسـائي : " أصـبحت نظرت إلى ذات التنـانير " (؛) ، يعـي ناقته ، ،

وشرط الكوفيون في ذلك اقترانه بـ " قد " ظاهرة أو مقدرة . (•)

بقي أن نقول : إن الأفعال الناقصة لا يقصد معها نسبة الحدث إلى اسمها

الأي هو بمنزلة الفاعل ، وإنما يقصد ثبوت خبرها المنسوب إلى اسمها . قال ابن الحاجب : " ولا يصح التعلق بالأفعال الناقصة لأنها لم يقصد بها في التحقيق نسبة حلث محقق إلى فاعلها ـ ومعنى قولنا : حدث محقق يعني : أنه لـ لـ يرد أن زيدا ثبت ، وإنما أريـا أن القيام المنسوب إلى زيد وهو خبره ثبت ، وذلك حاصل لو لـ تذكر " كان " ، وإنمـا قصد بالإتيـان بها على المبتدأ والخبر، وتفيد

$$
\begin{aligned}
& \text { (1) من الآية (؟ §) في سورة " إبراهيم " . }
\end{aligned}
$$

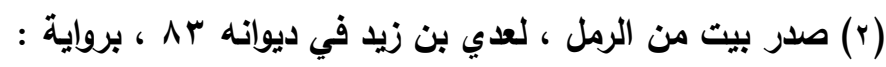

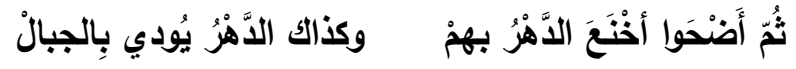

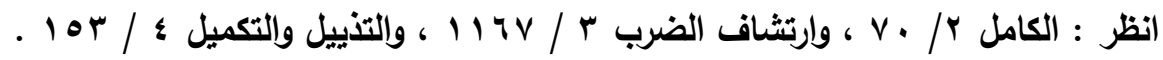

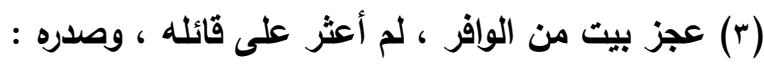

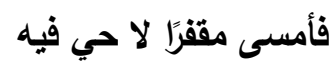

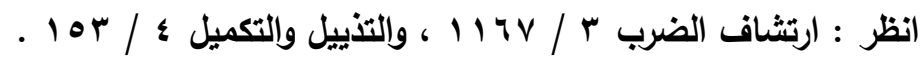

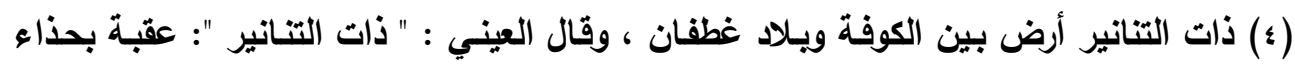

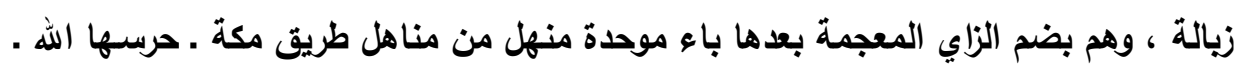

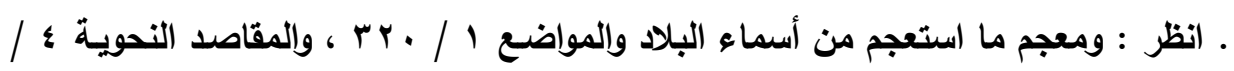


الخبر معنى بالنسبة إلى المبتدأ مع بقائه في الحقيقة مخبرا عنه على ما كان عليه

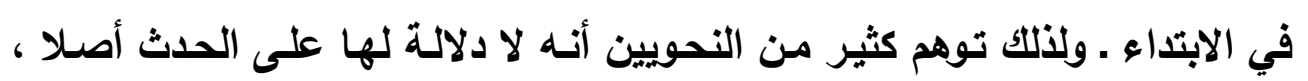
وإنما وضعت للالالة على مجرد الزمان ، فلذلك لم تأت عاملة في شيء غير الاسم

(1) والخبر

\section{الإقابل}

ويقابل النقصان هنا التمام •

ومعنى كون الأفعال هنا تامة أنها تكتفي برفع المُسنَدِ إليه على أنه فاعل لها

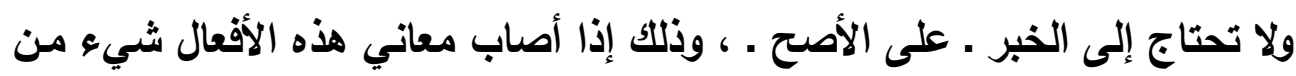
التغيير فعادت بمعنى فعل من الأفعال التامة ، ويتحقق ذلك في :

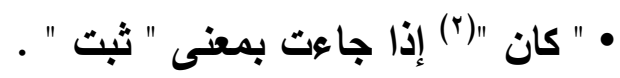

قال ابن مالك : " وثبوت كل شيء بحسبه ، فتارة يعبر عنه بالأزلية نحو : " كان الله ولا شيع معه " ، وتارة يعبر عنه بـ " حََث " ، كقوله :

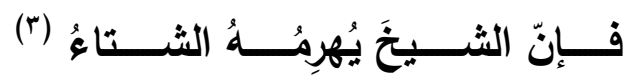

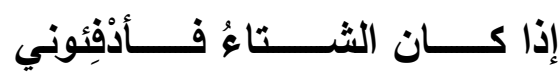
أي إذا وجد الثتاء أو حدث .

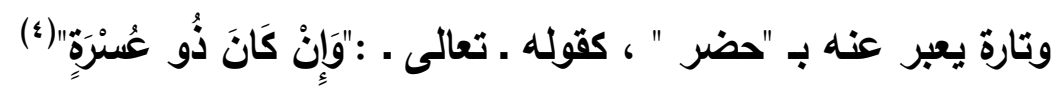

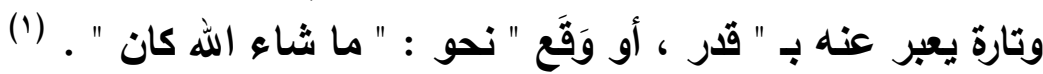

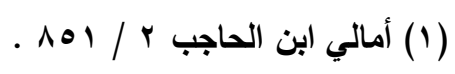

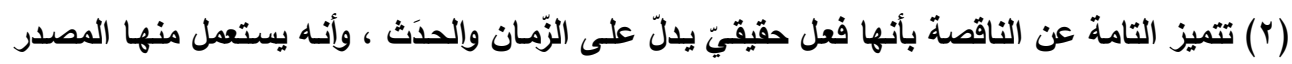

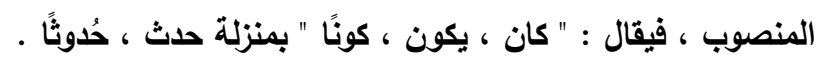

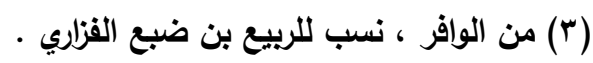

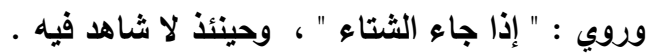

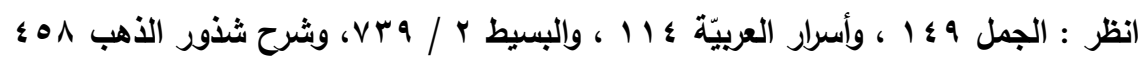

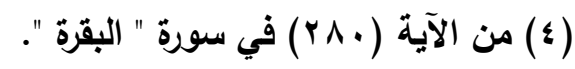


وقال البطليوسي : " وذكر اللغويون في غريب اللغات أن " كان " تكون بمعنى

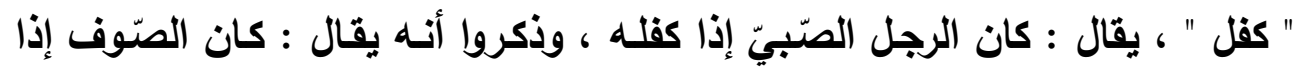
غزله و" كان " في هذين الموضعين ليست مما تدخل على مبتدأ وخبر وإنما هي فعل صحيح بمنزلة ضرب وقتل ونحوهما مما يتعدى إلى مفعول واحد.(r) وألحق ابن درستويه ، وابن الأثير بـ " كان " التامة " كان " الثانية ، وهي مـا

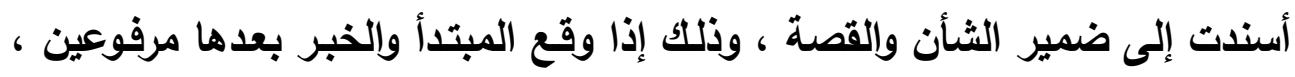
مثل " كان زيدٌ قائمُ " على أنهما خبرهـا ، واسمها ضمير الشـأن ، والجمهور على

أنَها من أقسام الناقصة وجعلها أبو القاسم ابن الأبرش قسما قائما برأسه (َّ).

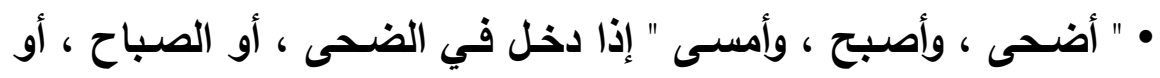

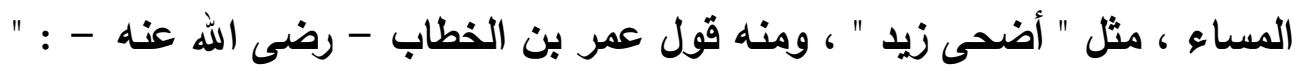

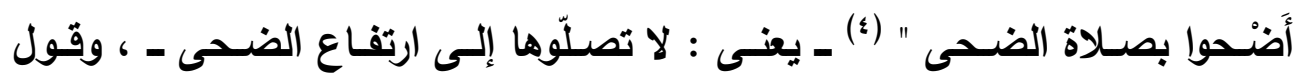
الشاعر :

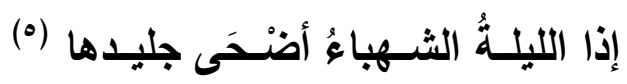

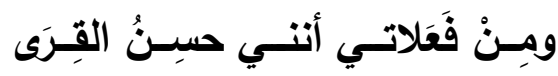
(1) انظر : سنن أبي داود باب ما يقول إذا أصبح V / / . . ، ، والنسائي في كتاب عمل اليوم

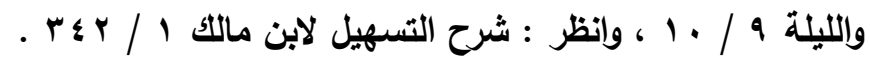

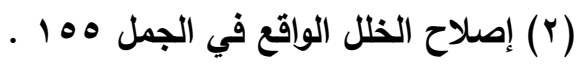

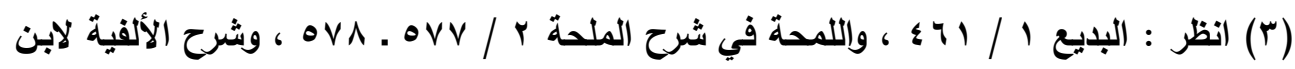

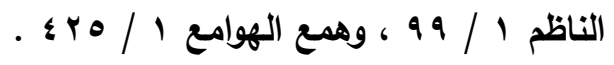

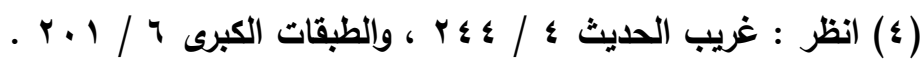

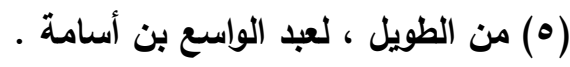

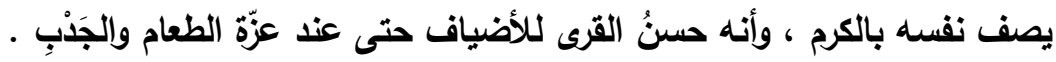

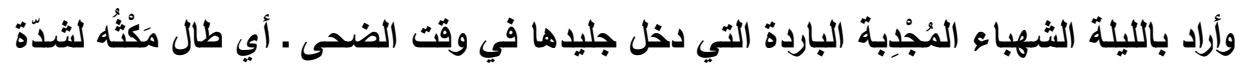

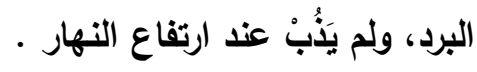




\section{أي: صار جليدها في وقت الضحى .}

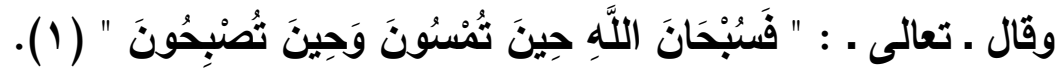
• " ظلّ " إذا جاعت بمعنى " دام " نحو : " لو ظلّ الظلم هلك النـاس " ، أو " طال " نحو : " ظل الليل ، و" ظل النبث " ، أو " أقام نهارا " نحو : " ظل محمد في (البيث " . (ب)

• " بات " إذا جاعت بمعنى " عرَّس " ـ وهو النزول ليلًا ـ نحو قول عمر رضي الله عنه .:"أما رسول الله ـ صلى الله عليه وسـلم ـ فقد بـات بمنى" (َّ) ـ أي: عرس بها . ، ومنه قول الشاعر :

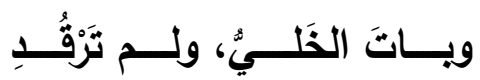

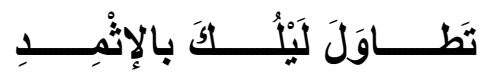

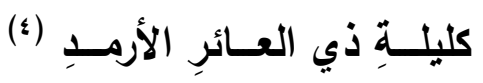

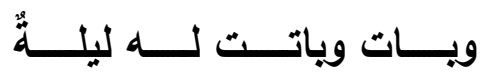
أو" نزل ليلًا " مثل " بات بالقوم " ـ أي نزل بهم ليلًا .

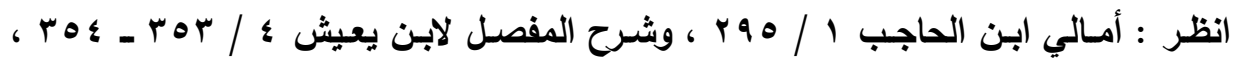

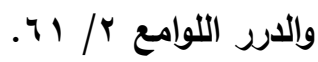

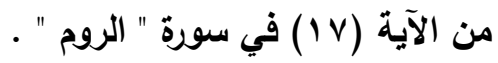

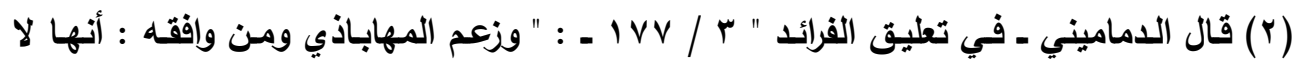

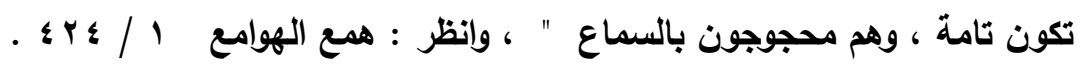

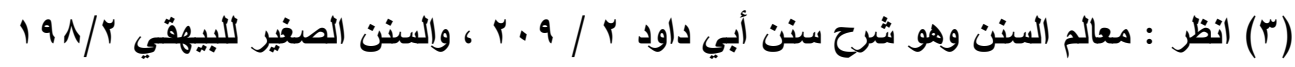

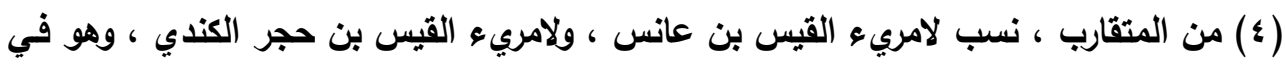

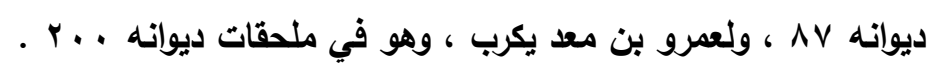

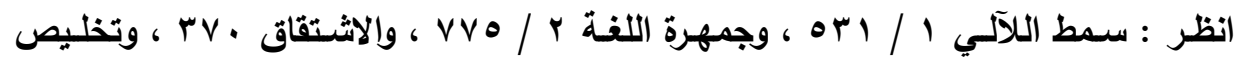

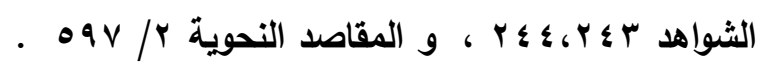




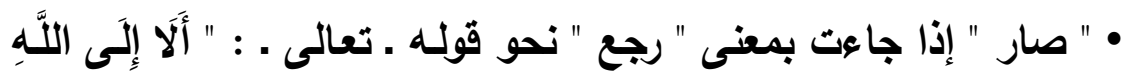

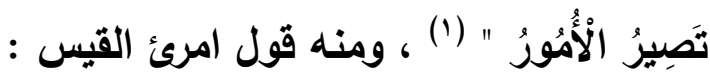

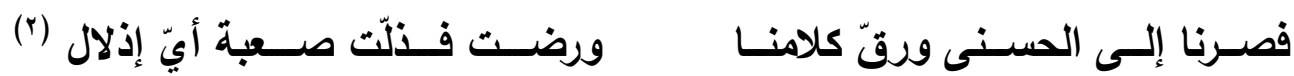

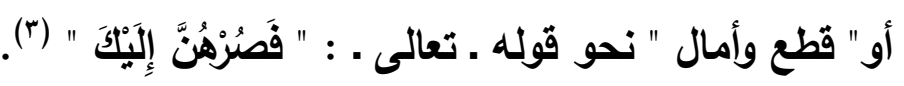

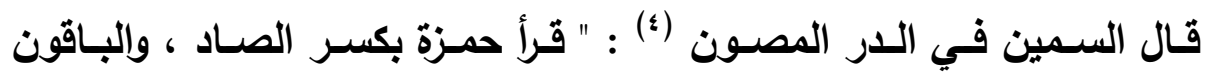

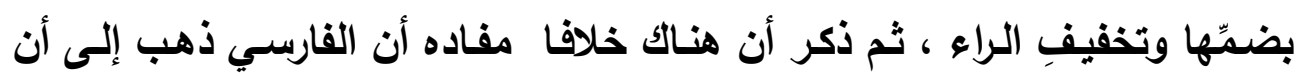

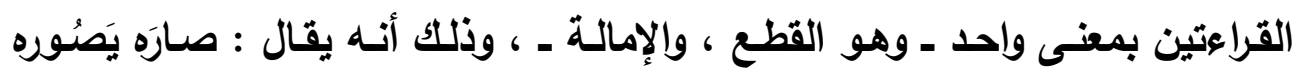

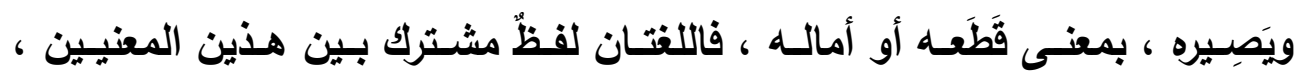

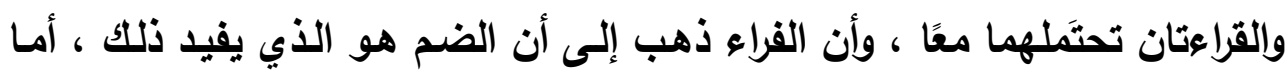

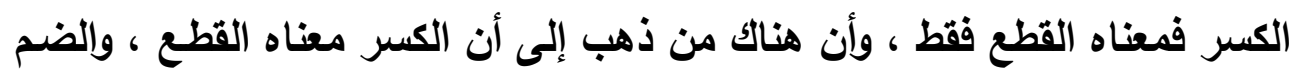

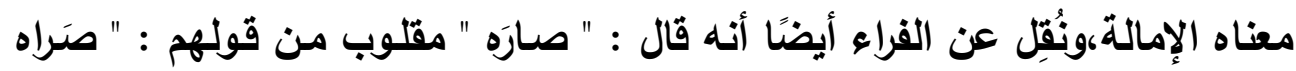

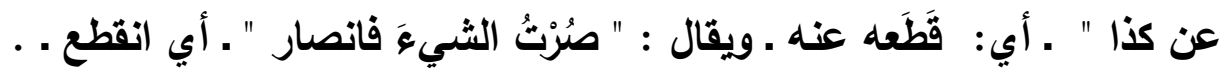
قالت الخنساء :

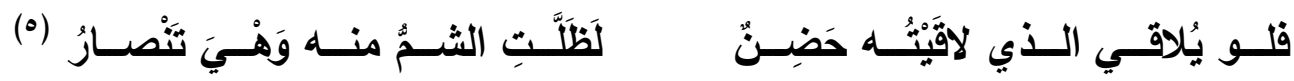

$$
\begin{aligned}
& \text { (1) من الآية (به) في سورة " الثورى ". }
\end{aligned}
$$

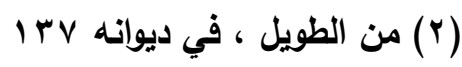

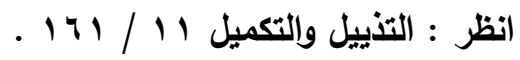

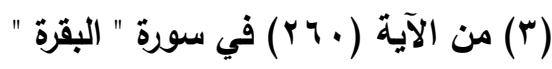

$$
\begin{aligned}
& \text {. }
\end{aligned}
$$

(0) من البسيط ، نسب للخنساء وليس في ديوانها

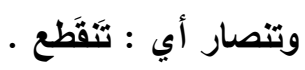


أو " انتقل " مثلـ ": صـار زيــ إلى موضـع كذا ـ أي انتقل . . (1)

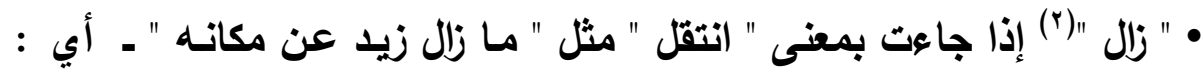

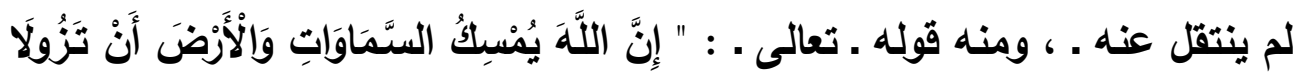

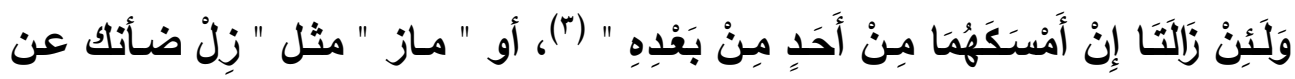

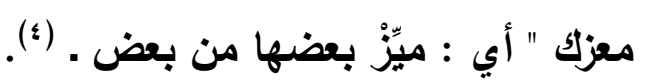

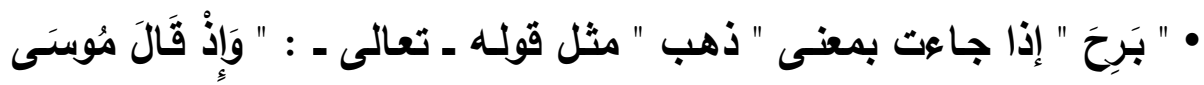

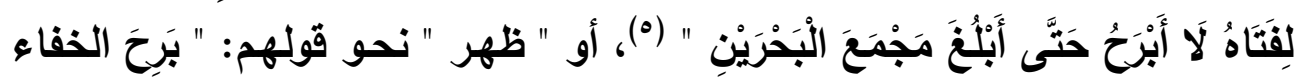

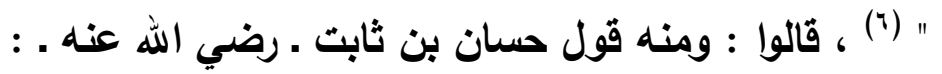

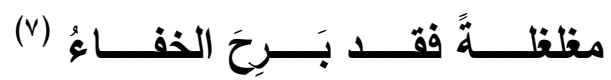

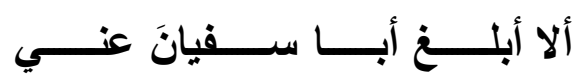

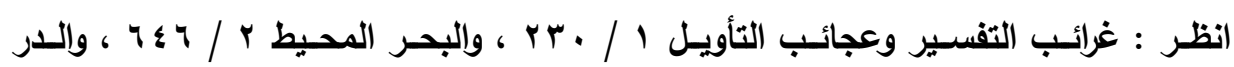

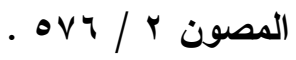

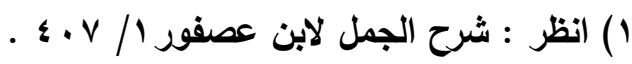

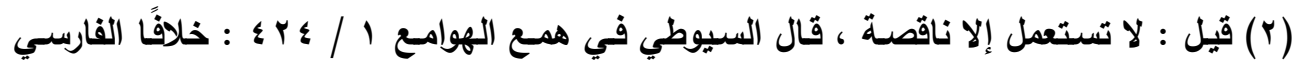

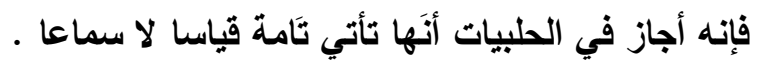

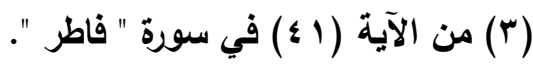

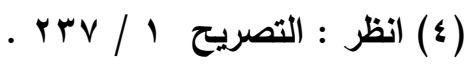

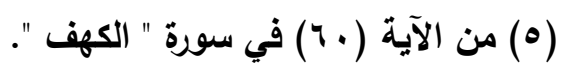

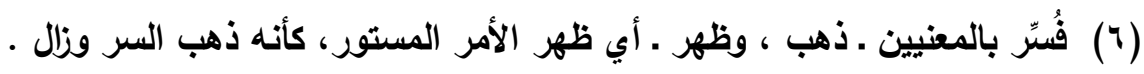

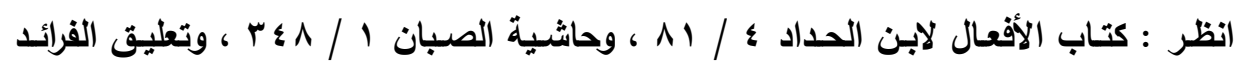
$.1 \Lambda \cdot / \mu$

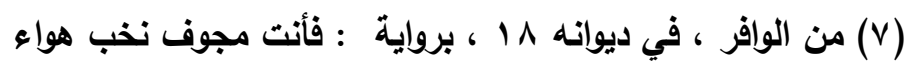

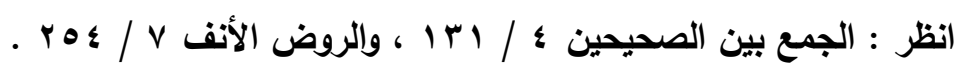




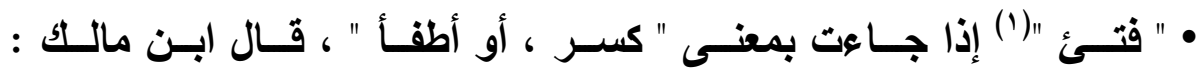

" وتتم " فتـئ " إذا أراد بها " كسر وأطفأ " ، قـال الفـراء : " فتأتـه عن الأمسر " :

كسرته ، و" فتأت النار : أطفأتها "(r).

• " انفلك " إذا جاءت بمعنى " خلص ، أَو انْفَصل " نحو " انفـك الأسير ، أو

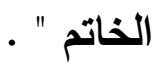

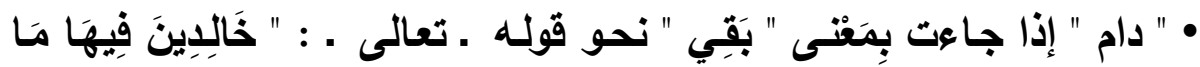

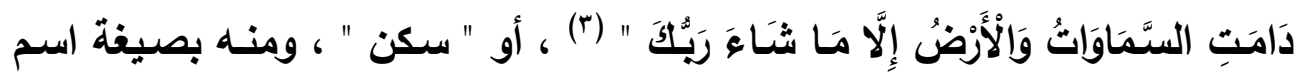
الفاعل قوله ـ صلى الله عليه وسلم ـ : " لا يبولئ أحدكم في المـاء الدّائم ويغتسل (๕) " مid

• " وني " إذا جاءت بمعنى " فتر وضعف " مثل " ونيث في الأمر " . (ه)

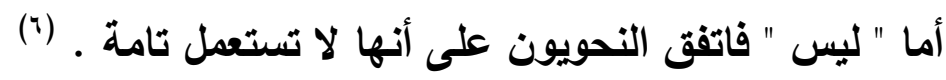

r ـ الناتمى في باب " كاد "

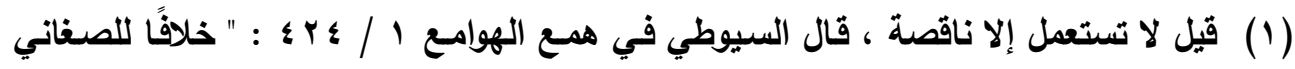

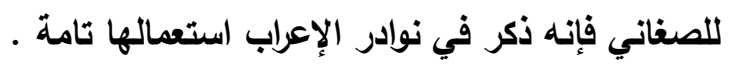

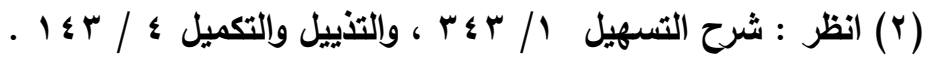

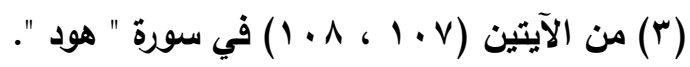

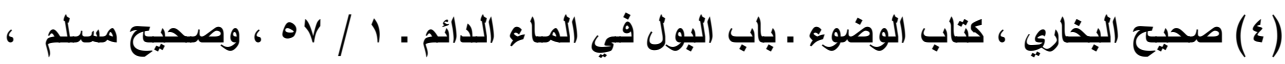

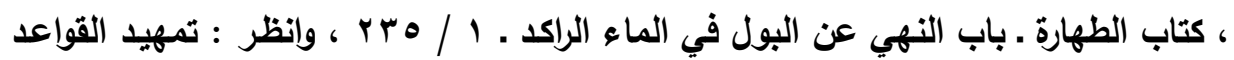

$$
.1 .9 r / r
$$

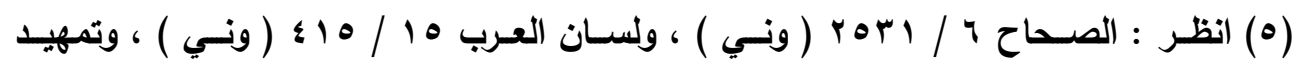

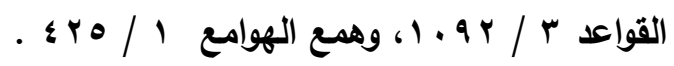

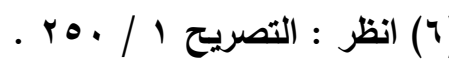


و" كاد " وأخواتها ـ أيضا ـ أفعال ناقصة تحتاج إلى اسم وخبر ، فيرتفع بها

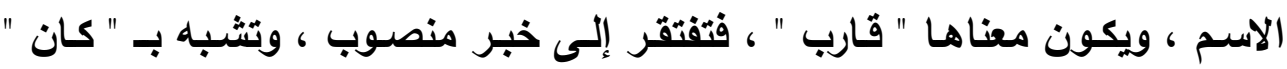

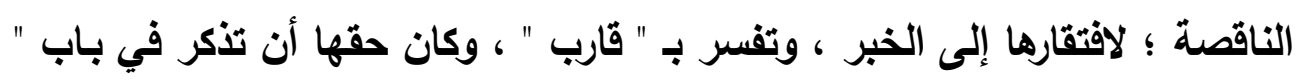

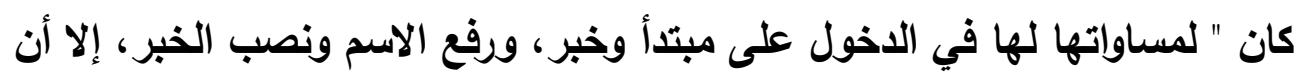

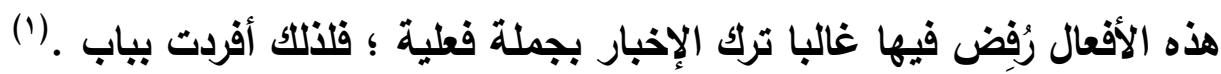

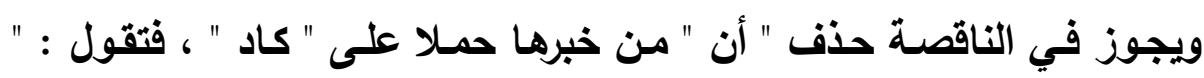

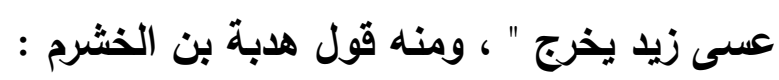

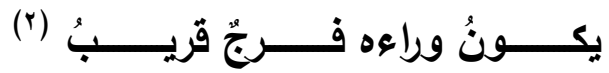

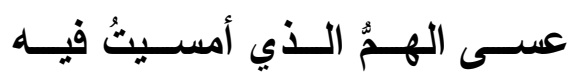

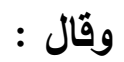

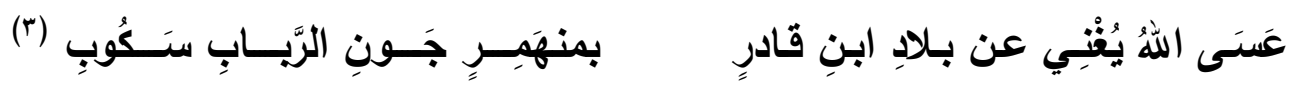

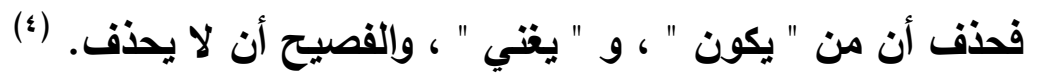

\section{الاقتابل}

المقابل في هذا الباب التمام ـ أيضًا كسابقه ـ ، فإذا تغير معنى هذه الأفعال

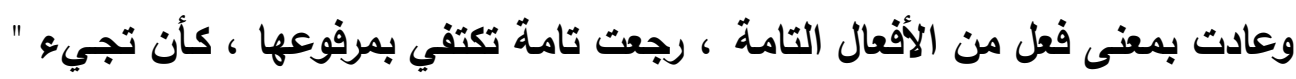

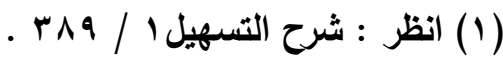

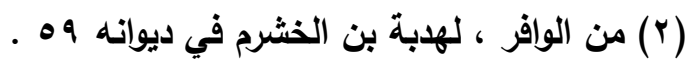

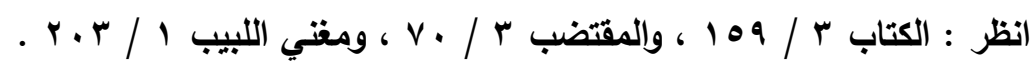

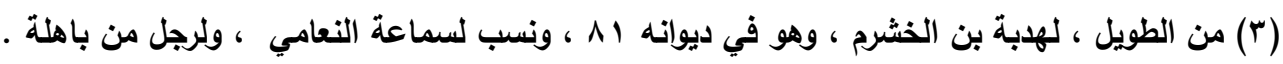

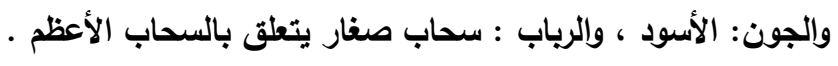

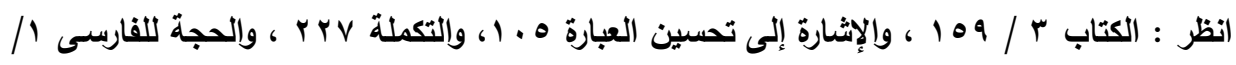

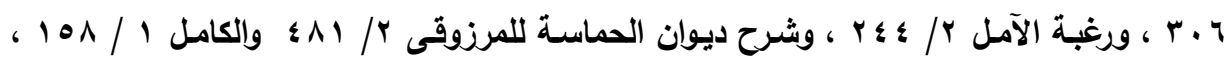

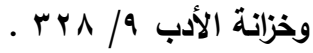

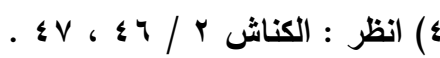




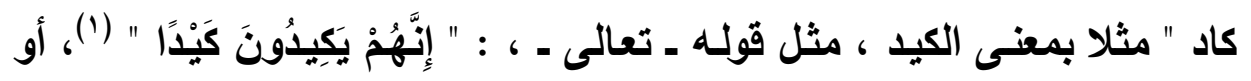

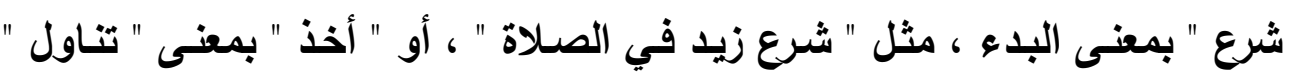

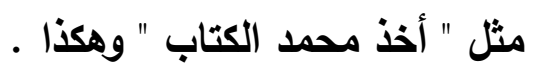

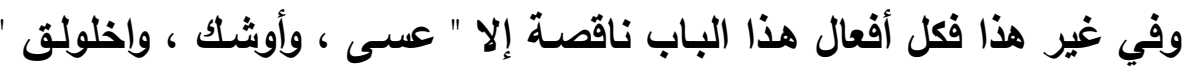

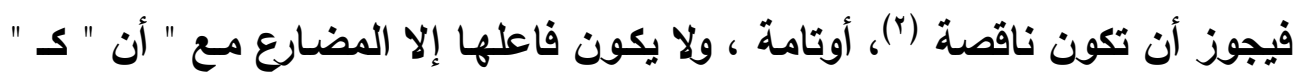

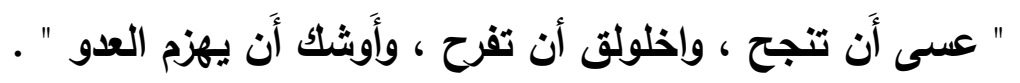

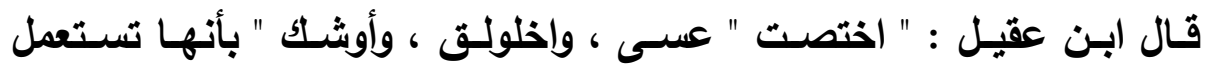

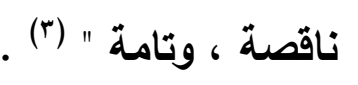

وقال السيوطي : " يسند " أوشكَّ ، وعسى ، وإخلولق " إلى " أن يفعل " فيغني

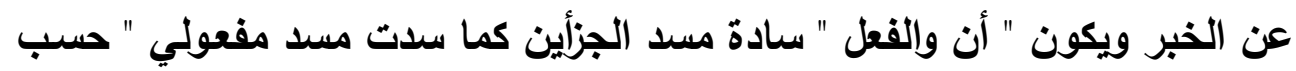

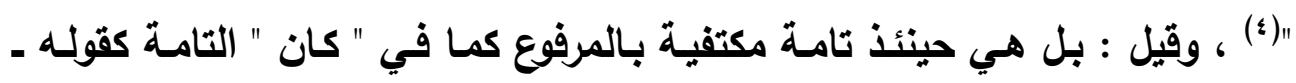

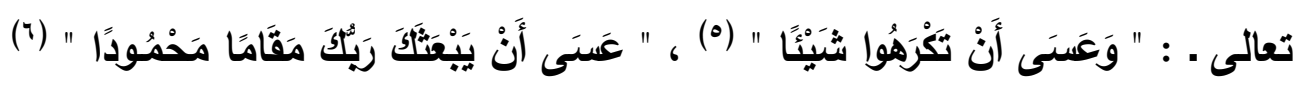
، وقال الثاعر :

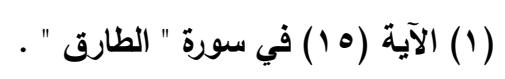

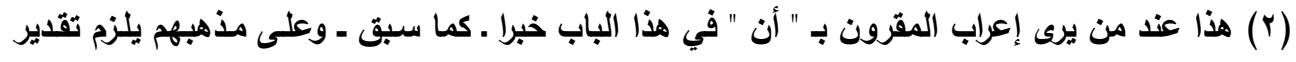

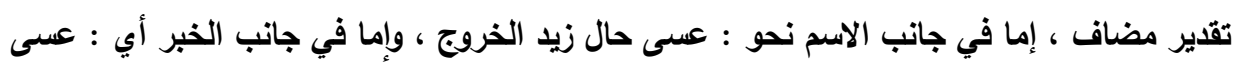

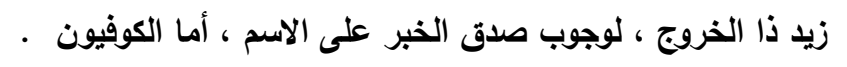

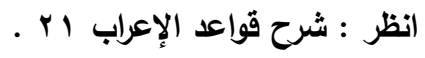

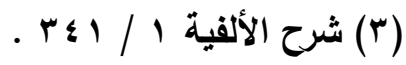

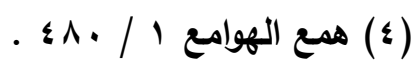

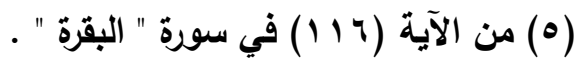

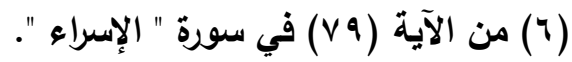




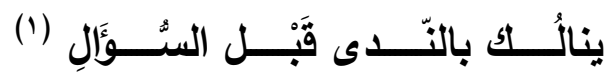

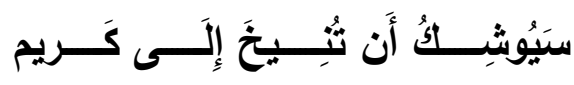
ومثل هذا البيت قوله :

بـه الجهـل أو صسارمته ، وهـو عاتـب إذا أنــت لـم تغفـر لمـولاك أن تـرى

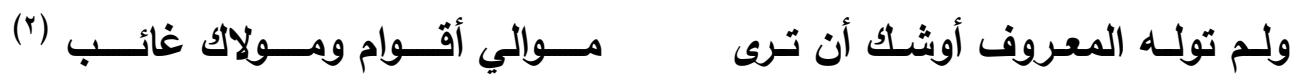
وتقول : " اخلولق أَن تمطر السيَّمَاء " .

(1) من الوافر ، نسب لكثير عزة ، وليس في ديوانه .

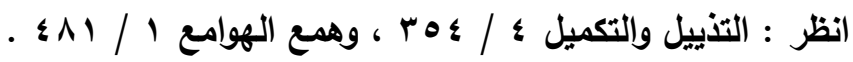

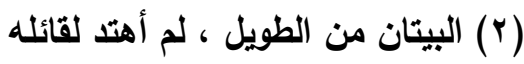

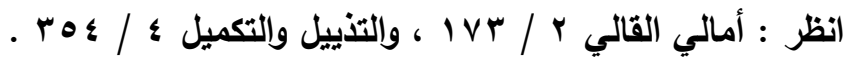


وقال الخضراوي لا يجوز ذلك في " اخلولق " بل يختص بـ " أوشك ، وعسى

$$
\text { ولابد أن يكون بعدها " أن " ، والفعل في موضع رفع • }
$$

ويستغنى في هذا الوجه بذكر ما تضمنه اسمها من الحدث عن الخبر الذي

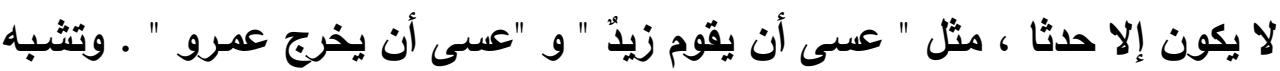

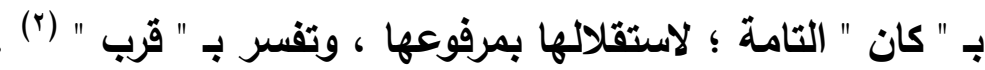

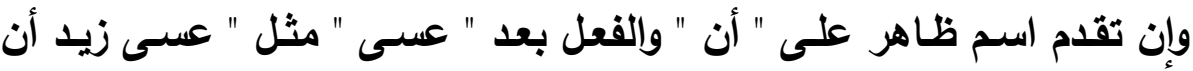
يقوم " كان في " يقوم " ضمير يعود على " زيد " ، مطابق ـ في الإفراد وفروعه ، والتذكير وفرعه ـ لهذا الاسم المتقدم ، فيقال : " عسى القتاة أن تقوم ، والزيدان أن لن يقوما ، والزيدون أن يقوموا ، والفتيات أن يقمن " . وإن تأخر ذلك الظاهر ، وتوسطت " أن " والفعل بين " عسى " والاسـ الظاهر

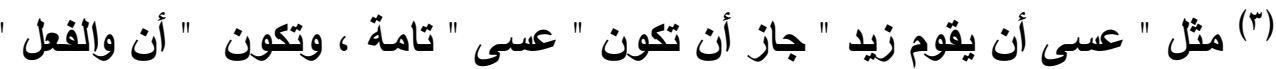
في موضع رفع بها ، ويكون " زيد " مرفوعًا بالفعل الأي في صلة " أن " لا بعسى ، فيكون الفعل في هذا الوجـه موحدًا على كل حال لأنـه لا ضمير فيهه ، فيقال : "

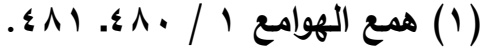

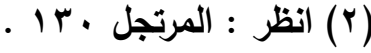

(r) في جـواز توسـط " أن " والفعل بـين " عسـى " والاســ الظـاهر خـلاف ، فقــ أجـازه المبـرد

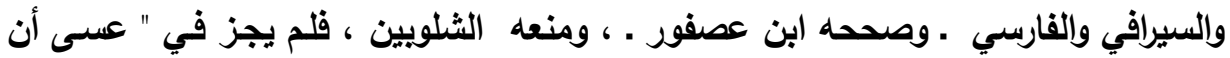

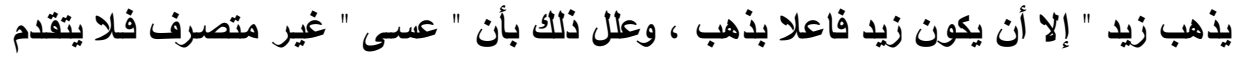

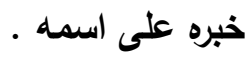

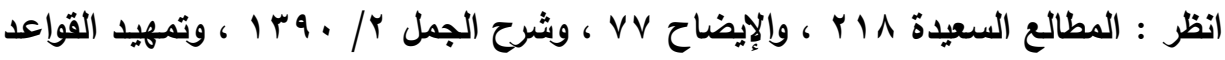
. I rVo/r 
عسى أن تقوم الفتاة ، وأن يقوم الزيدان ، وأن يقوم الزيدون ، و أن تقوم الفتيات .

ويجوز أن تكون " عسى" ناقصة ، و " زيد " مؤخرًا مرادًا به التقديم ، مرفوعًا

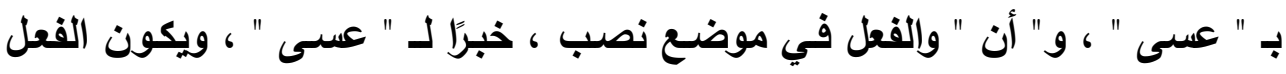

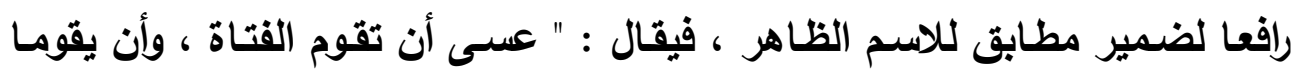

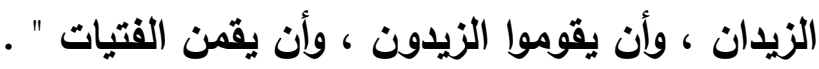

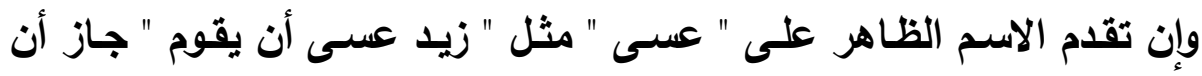

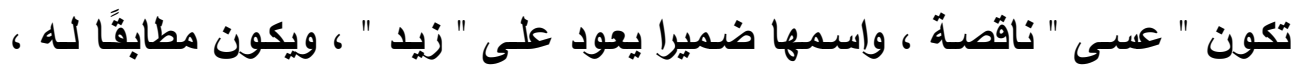

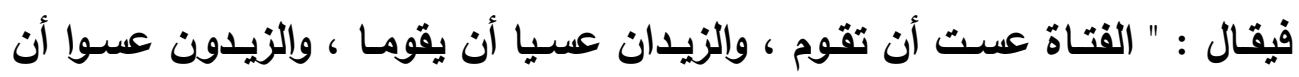
يقوموا ، والفتيات عسين أن يقمن " .

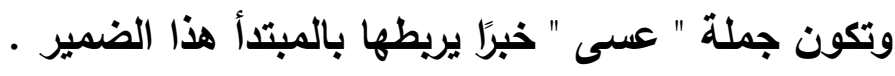

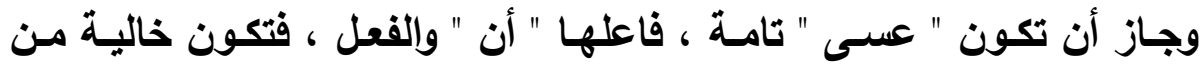

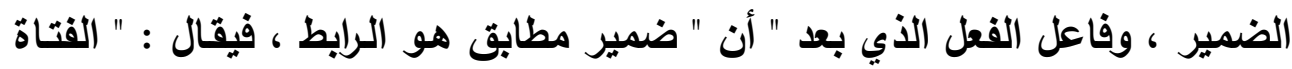

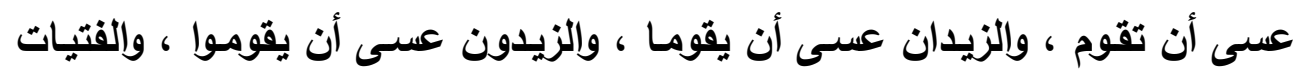

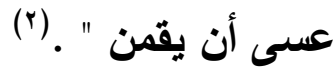

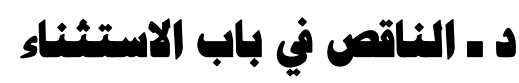
الناقص هنا هو مالم يذكر فيه المستثنى منـه ، ولابد أن يكون الكلام غير

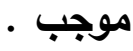
وغير الموجب هو المشتمل على نفي ، أو نهي .

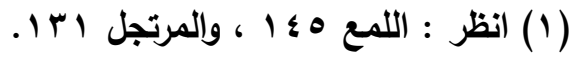

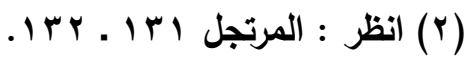


والنفي أن يقع في أَول جملة الاستثناء نفي أو نهي أو استفهام ، " مـا فاز

أحد إلا المُجدِّ " . (1)

قال ابن يعيش : " وغير الموجب مـا كان فيه حرفتُ نافٍ ، أو استفهام ، أو

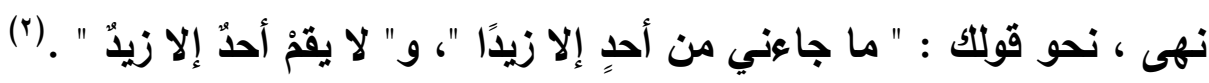

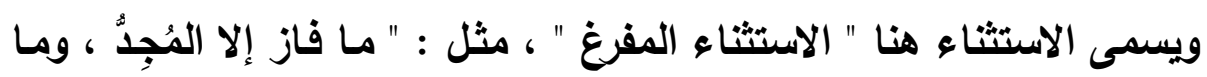
أكرمت إلا الكريم ، وما أكلت إلا من الحلال " .

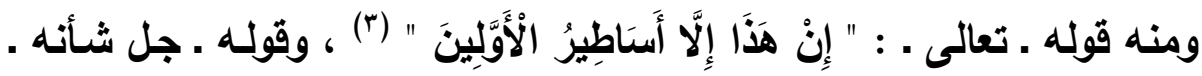

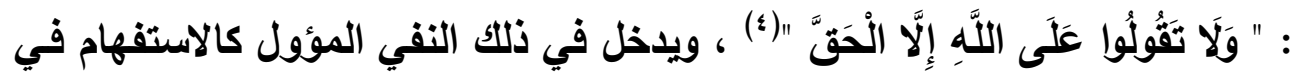

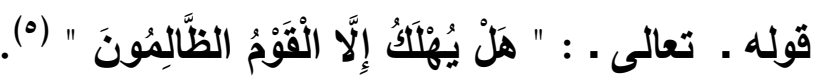

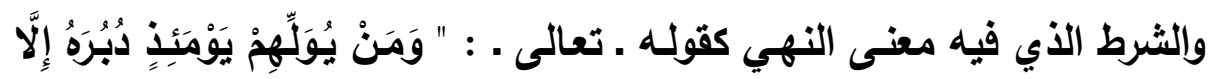

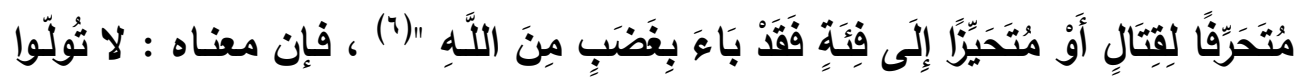

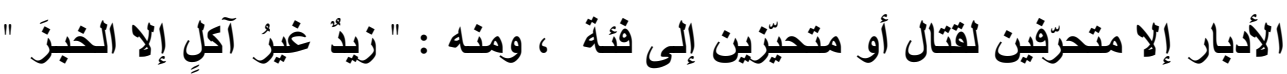

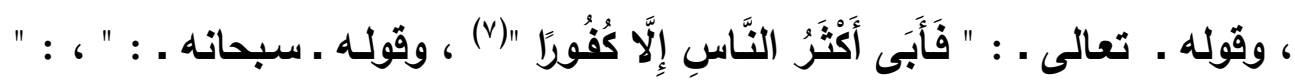

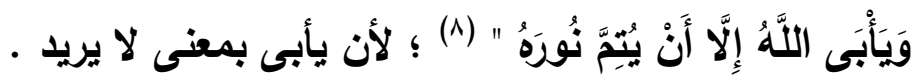

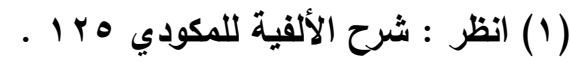

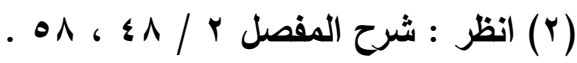

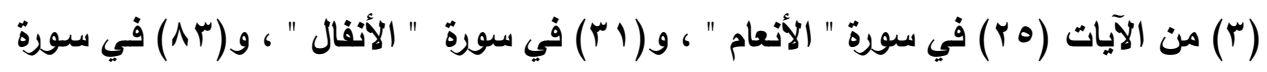

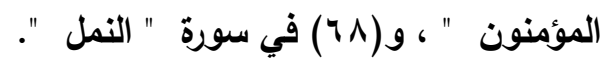

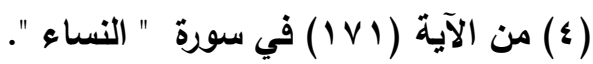

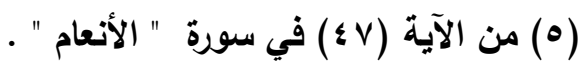

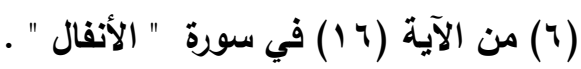

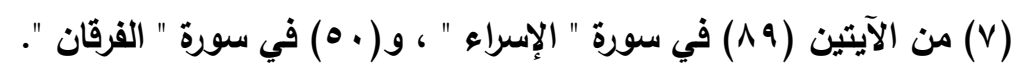

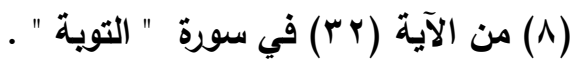




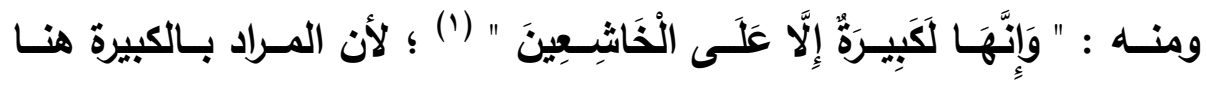
الصعوية ، فكأنه قيل : لا تسـهل إلا على الخاشـعين ، وكذلك : " قَالَ مَعَاذَ اللَّهِهِ أَنْ

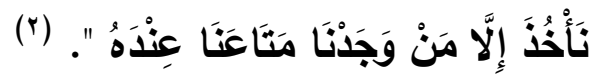
ومنه أيضا قولهم : " قلّ رجلّ يقول ذلك إلا زيدا " ، و" أقل رجل يقول ذلك إلا

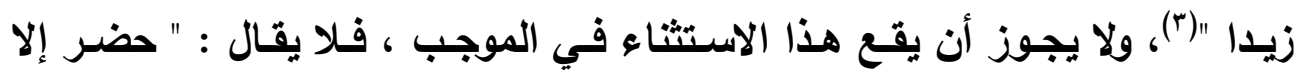

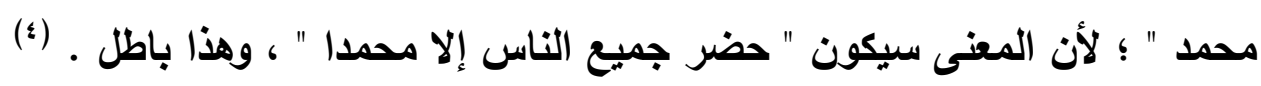

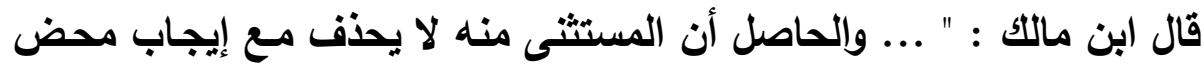

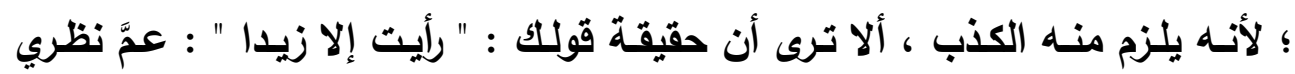

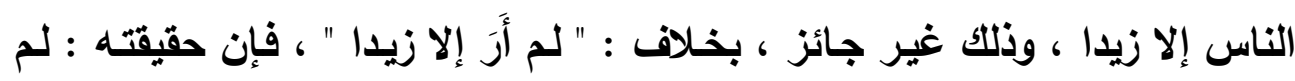
أَزَ مـن النـاس إلا زيـدا ، وذلك جـائز ، فبإن كـان في الإيجـاب معنى النفي عومـل معاملته نحو : " عدمتُ إلا زيدا ، وصمت إلا يومَ الجمعة " ، فإنهما بمعنى لـ أجد الجد ولم أفطر ". (•) إلا إذا كـان هنـاك قرينـة على إرادة جماعـة مخصوصـة كمـا في " حضـر إلا

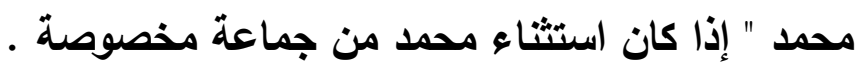
قال الرضي : " ويمكن أن يقوم ـ في بعض المواضع على بعض معين من الجنس معلوم دخول المستثى فيه ـ دليلٌ ، كما إذا قيل للك : " ما لقيت صناع البلد

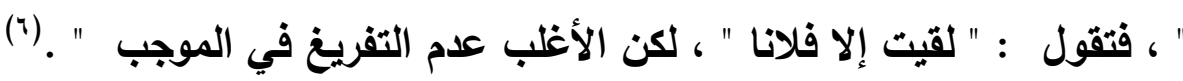

$$
\text { (Y) من الآية (0) (1) ) في سورة " البقرة ". }
$$

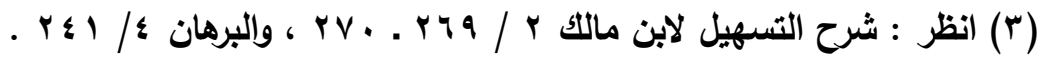

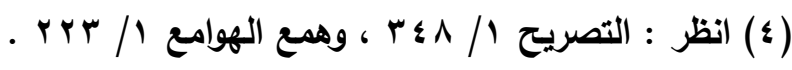

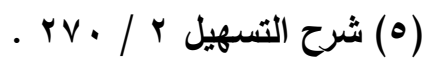

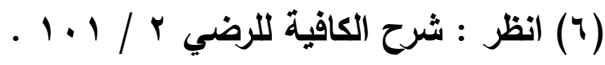


قال في الفوائد الضيائية " وقد يفرغ في الإيجاب لقصد المبالغة كأن تقول

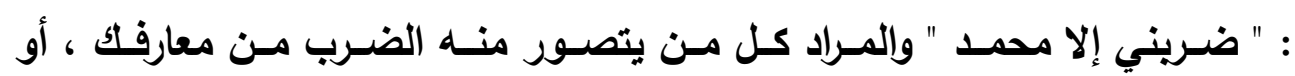

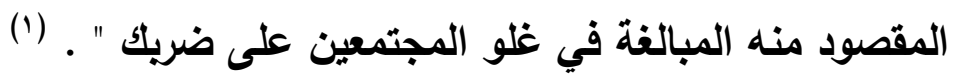

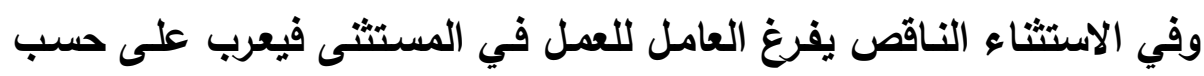
موقعه في الجملة قبل دخول " إلا " . قال ابن الخشاب : " فإن كان الفعل قبل فيل إلا مفرغا لما بعدها كان لما لما بعدها

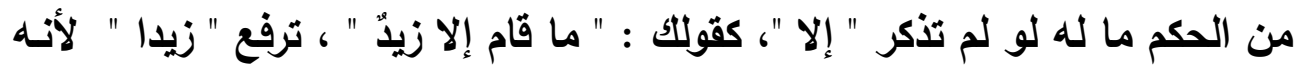

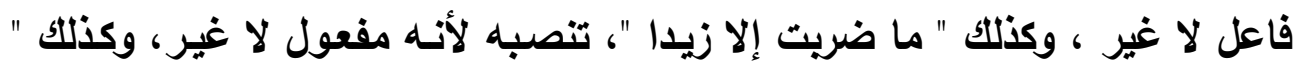

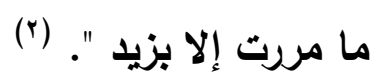
قال ابن يعيش : " وإلذي يدل على أنّ الفعل عامل فيما بعد " إلا " ومسند إليه

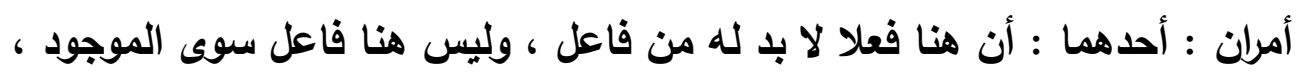

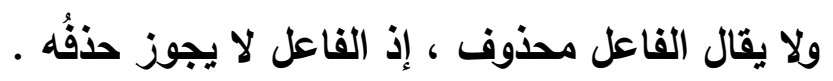

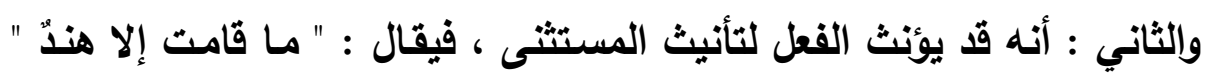
قال ذو الرُمَّةَة :

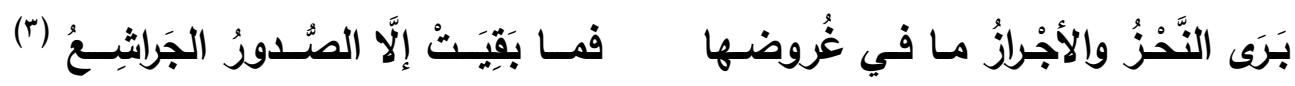
ومن ذلك قراءة الحسن ، وجماعة من القراء غير السبعة : " فأصنبَحُوا لاَ تُرَى

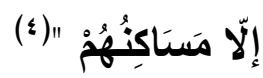

(1) انظر : الفوائد الضيائية 99 (1) 19.

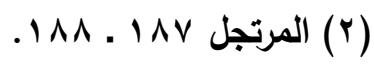

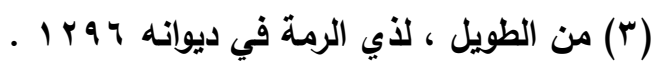

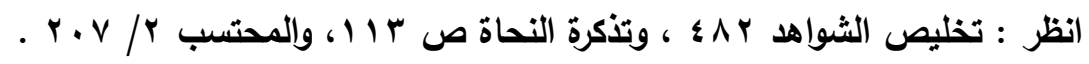

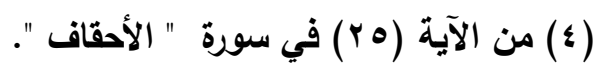


وهي قراءة ابن كثير ، وعاصم ، والحسن ، والأعمش ، وغيرهم . (1)

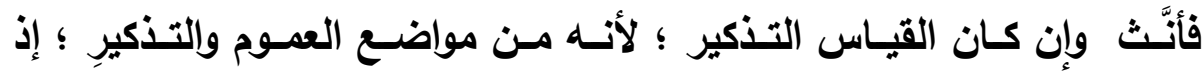

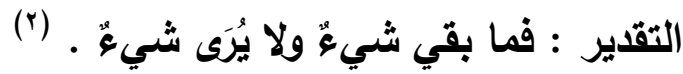
قال ناظر الجيش : " التفريغ يأني في جميع المعمولات من فاعل ، ومفعول ومجرور ، وظرف ، وصفة ، وحال . ولم يستثنوا إلا المصدر المؤكد ؛ إذ لا فائدة فيـه ؛ لأنّه بمنزلـة تكرار العامل وهل فلا يجوز : " ما قمت إلا قيامـا " إذ يصير المعنى مـا قمت إلا قمت ، وأمسا قولـه .

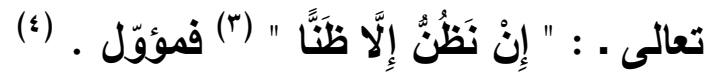

\section{الإقابل}

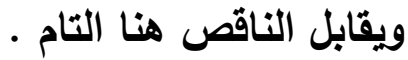

والتتام هنـا هو مـا ذكر فيـه المستثنى منـه ، ويكون موجبـا ومنفيَّا ، ومتصـلا

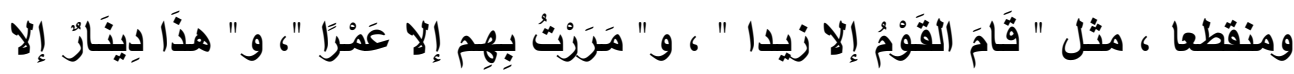

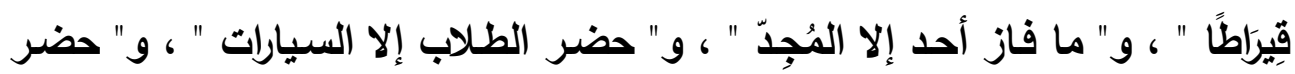

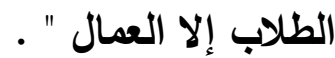

وقد سبق الكلام على كل هذا وأحكامه في مبحث " المتصل " .

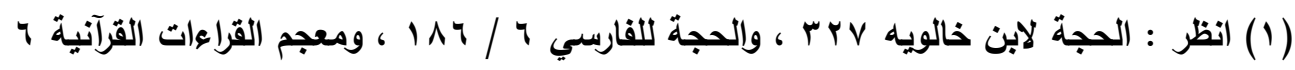

$$
\begin{aligned}
& \text {. IVT/ }
\end{aligned}
$$

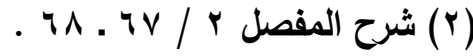

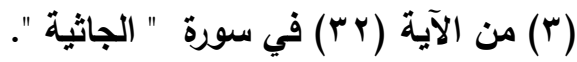

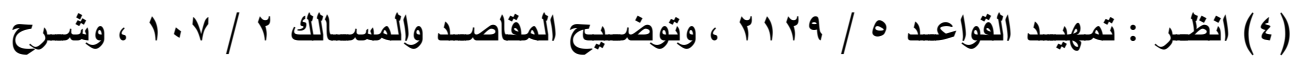

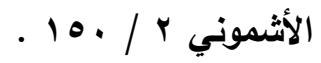




\section{الخاتمة}

الحمد الله الأي بنعمته تتم الصالحات .

$$
\text { ويعد : }
$$

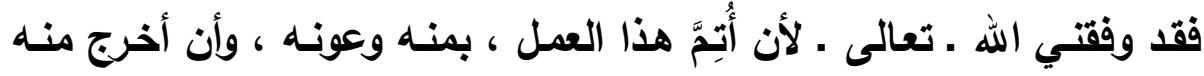

• أن " المصطلح " في كل فَنٍ مفتاحسه ، ولكل صناعة ألفاظ ـ كما يقول

$$
\text { الجاحظ (') - (ان }
$$

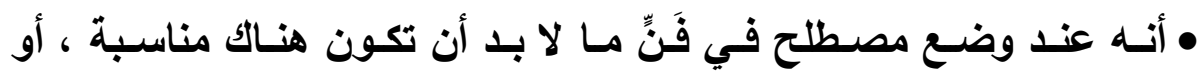

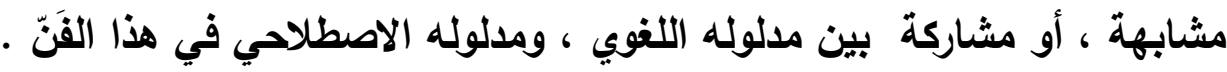

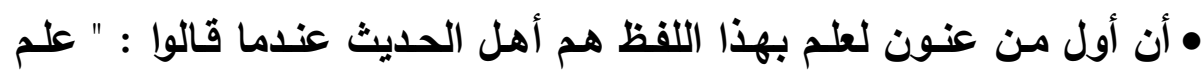

$$
\text { مصطلح الحديث " . }
$$

• أن بدايات وضع المصطلحات النحويـة كانت على يد البصريين الذين بدأ

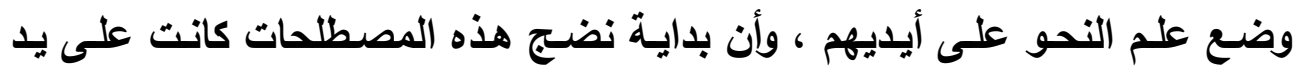
الخليل وسيبويه .

• أن المصطلح النحوي قد يتعدد للمفهوم الواحد بسبب التطور الزمني ، أو

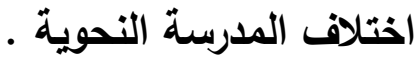

• معرفة مدلول كل مصطلح أمر لابد منه لمن يريد خوض غمار هذا الفن ،

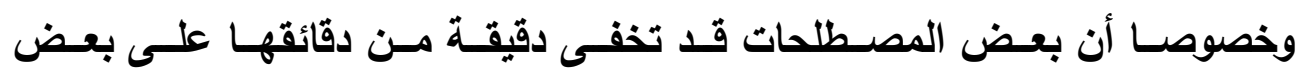
المتخصصين في هذا الفن ، وذلك مثّلا كمصطلح " الاستثاء المنقطع " الذي يعتقد

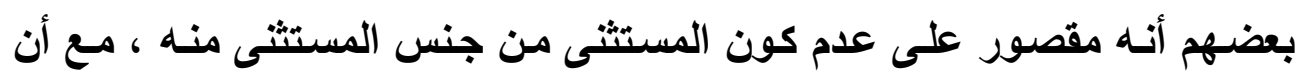
الاستثناء من الجنس قد يكون منقطعا إذا كان هذا المستثنى خارجا عن المستثنى 
منـه حين إطـلاق الحكم عليـه ، كمـا في " جـاء القـوم إلازيــا " ، عنـــ الحكـم بالمجيء على جماعة ليس زيل منهم ، فيكون زيد قد خرج من القيام الأي حُكمِ بـه على القوم ، لا من القوم ، قال ابن الخباز : " ومن توهم هذا فقد أخطأ " . ويهذا يُعْلَم أن تعريف هذا المصطلح بـالتعريف السـابق جَرْيُ على الغالب كمـا

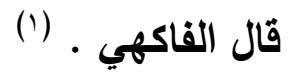
• أن العلوم المختلفـة قد تشـترك في مصطلح واحد ، ويزلداد الأمسر صعوية عندما يتعدد المصطلح ويختلف مدلوله في باب عن آخر في العلم الواحد ، وهذا قـ يرهق الناظر في هذا الفن ، وخصوصا المبتِّئ ، وقد يرهق من يقوم بتوصيل هذا الفن إلى ذلاك المبتدِئ .

وقد وجدت ذلك جَلًِّا في فن النحو ؛ إذ لا نكاد نرى للمصطلح الذي تكرر في أكثر من باب تعريفًا شافيًا ، وريما رأينا تعريف ذلك المصطلح بمقابله ، كمصطلح " المفرد " مثثلا الذي يعرف في أبواب الخبر والحال والنعت بأنهه " مـا ليس جملة ولا شبه جملة " ، وفي بـابي " لا " النافية للجنس والمنـادى بأنـه " مـا ليس مضـافا ولا شبيها بالمضاف " ، وغير هذا مما مرّ في هذا البحث . ومن هنا فإني أرى أن يعاد النظر في تسمية بعض المصطلحات ، وأن يقوم على هذا العمل لجنة من الغُير على هذا الفن ، الأين يعرفون للتراث قدره ، ويكون

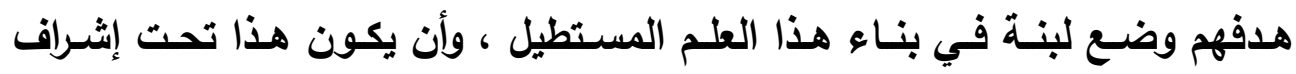

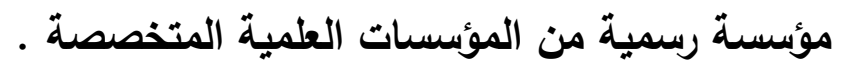

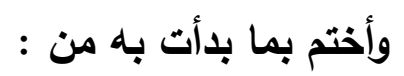

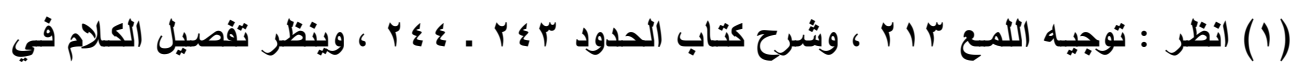
هذا في مبحث الاتصال ومقابله في باب الاستثناء . 
سؤالي لمن وجد في عملي هذا مخالفا للصواب ـ أو الأولى ـ أن يُهديَ إليّ

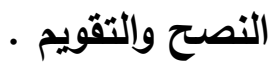
ودعائي أن يجعل الله ما كان من ثواب في هذا العمل في ميزان حسنات والِادَيَّ وحسناتي

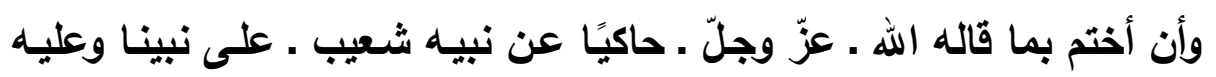

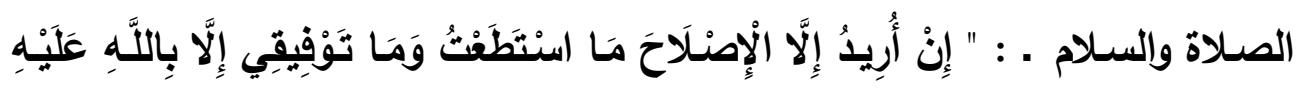

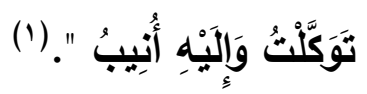

(1) من الآية (^^) في سورة " هود " . 


\section{ثبت بأهم الصادر والمراجع}

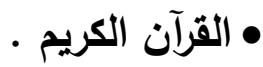

• إتــاف فضـلاء البشـر في القراعات الأربعـة عشـر لعبد الغتـي الـمياطيّ،

شهاب الاين ، تحقيق : أنس مهرة ،الناشر: دار الكتب العلمبة - لبنان ، الطبعة :

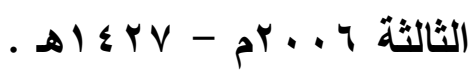

• أخلاق النبي وآدابه للشيخ الأصبهاني ، تحقيق : صـالح بن محمد الونيان

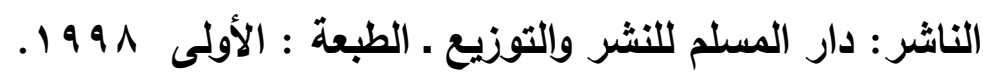

• ارتشاف الضرب من لسان العرب ، لأبي حيان الأندلسي ، تحقيق وشرح

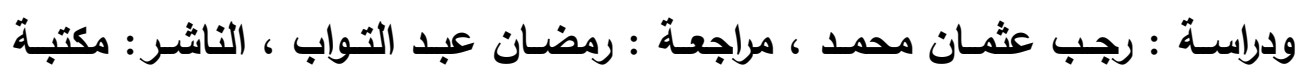

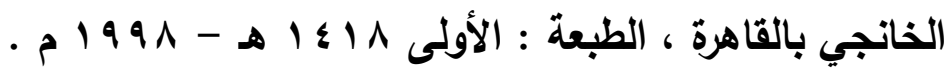
• أسرار العربية لأبي البركات ، كمال الدين الأنباري ، الناشر: دار الأرقم ابن

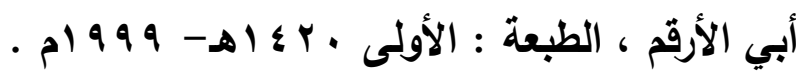
• الاثتقاق لابن دريد الأزدي ، تحقيق وشرح عبد السلام محمد هارون ، دار

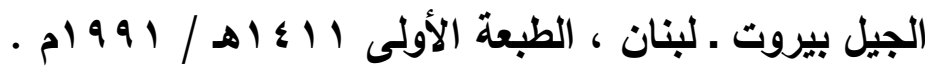
• إصلاح المنطق لابن السكيث ، تحقيق : محمد مرعب ، الناشر: دار إحياء

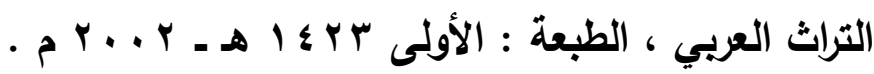
• الأصول في النحو لابن السراج ، تحقيق : عبد الحسين الفتلي ، الناشر: مؤسسة الرسالة لبنان - بيروت .

• الاقتراح في أصول النحو وجدله لجلال الدين السيوطي ، حققه وشرحه : د.

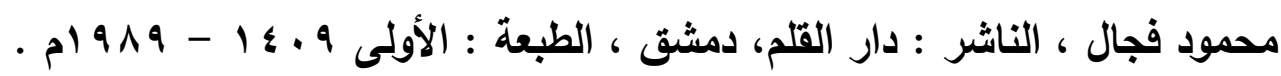
• الإقتاع في القراءات السبع لابن البَاذِش ، الناشر : دار الصحابة للتراث . 
• الألفـاظ والمصطلحات المتعلقـة بتوحيد الريويـة لآمـال بنت عبد العزيـز

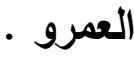

• ألفية ابن مالك ، طبعة دار التعاون ـ دون تاريخ . • أمالي ابن الحاجب لابن الحاجب الكردي المالكي ، دراسة وتحقيق : د. فخر صالح سليمان قارة ، الناشر : دار عمار - الأردن ، دار الجيل - بيروت ، 9 . ع 1 - $1919-1$

• أمالي ابن الشجري لابن الشجري ، تحقيق : الاكتور محمود محمد الطناحي

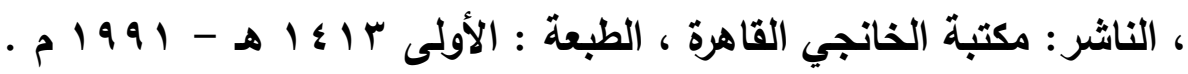
• الأمـالي لأبسي علـي القـالي ، عنـي بوضـعها وترتيبها: محمـد عبد الجـواد

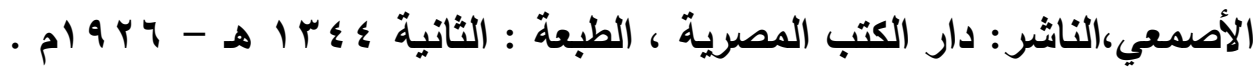

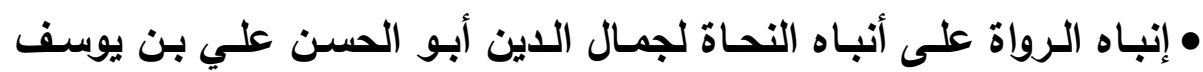
القفطي ، تحقيق : محمد أبو الفضل إبراهيم الناشر: دار القكر العربي - القاهرة ،

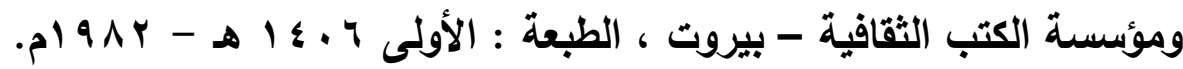
• الإنصـاف في مسـائل الخـلاف بـين النحـويين البصـريين والكـوفيين لأبـي البركـات كمـال الـدين الأنبـاري ، الناشـر : المكتبـة العصـرية ، الطبعـة : الأولـى

$$
\text { • }
$$

• أوضح المسالك إلى ألفية ابن مالك لجمال الدين ، ابن هشـام ، تحقيق : يوسف الشيخ محمد البقاعي ، الناشر: دار الفكر للطباعة والنشر والتوزيع •

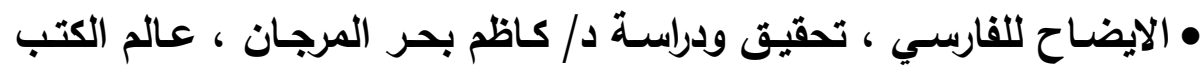

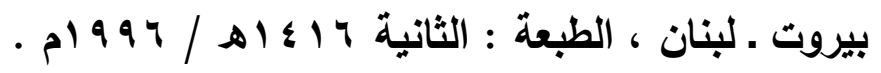
• الايضاح في شرح المفصل لابن الحاجب النحوي ، تحقيق د/ موسى بناي العليلي ، مطبعة العاني - بغداد . 
• البحر المحيط في التفسير لأبي حيان الأندلسي ، تحقيق : صدقي محمد جميل ، الناشر: دار القكر - بيزوث ، الطبعة : · ب ع ا هـ . . • البديع في علم العربية لأبي السعادات المبارك ابن الأثير ، تحقيق ودراسـة: د. فتحي أحمد علـي الداين ، الناشر : جامعـة أم القـرى مكـة المكرمسة - المملكـة

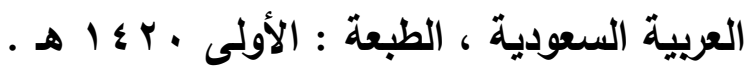
• البرهان في علوم القرآن للزركشي ، تحقيق : محمد أبو الفضل إبراهيم ،

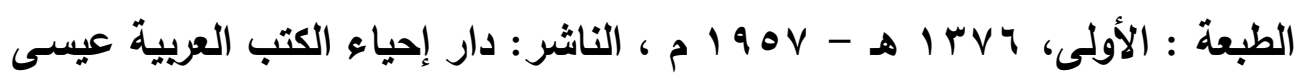
البابى الحلبي وشركائه . • البسيط في شرح جمل الزجاجي لابن أبي الربيع ، تحقيق ودراسـة د/ عياد

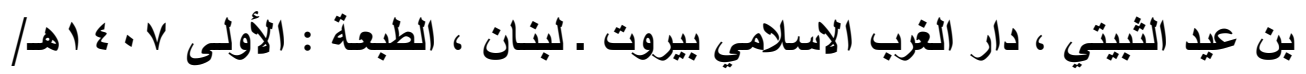
- 1917

• تاج العروس من جواهر القاموس للزَّبيدي (المتوفى: ه • ا اهـ) ، تحقيق : مجموعة من المحققين ، الناشر : دار الهداية . • التبيين عن مـذاهب التحويين البصـيين والكـوفيين لأبسي البقاء العكبري البغدادي ، تحقيق : د. عبد الـرحمن العثيمسين ، الناشـر : دار الغرب الإسـلامي ،

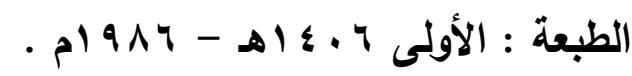

• تخلـيص الشـواهد وتلخيص الفوائد لابـن هثـام الأنصساري ، تحقيـث : د. عباس مصطفى الصسالحي (كلية التربية - بغداد) ، الناشر : دار الكتاب العريسي ،

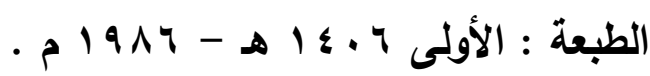

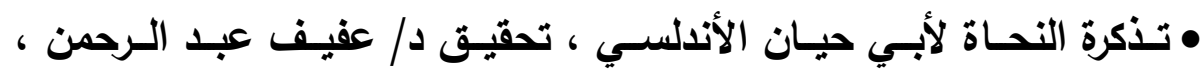

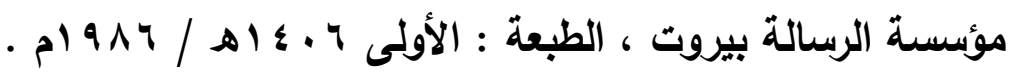


• التنييل والتكميل في شرح كتاب التسهيل لأبي حيان الأندلسي ، تحقيق : د.

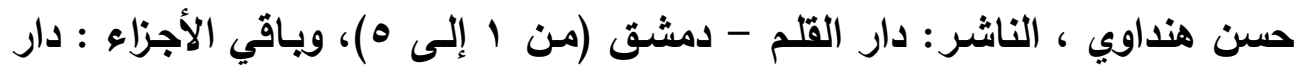

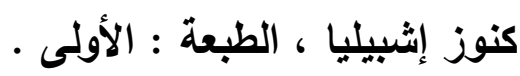

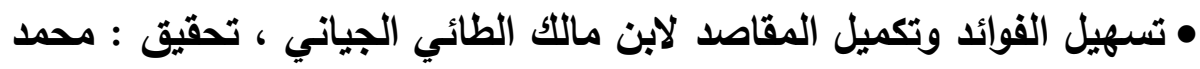

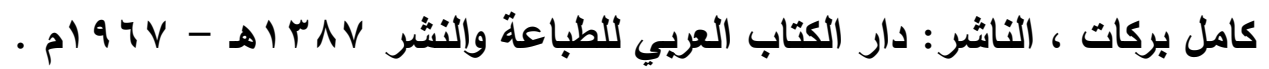

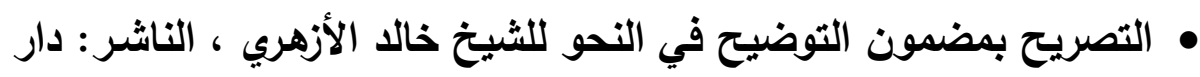

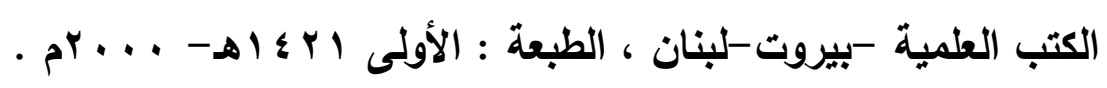

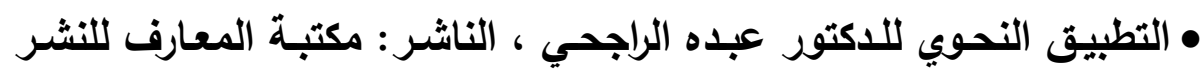

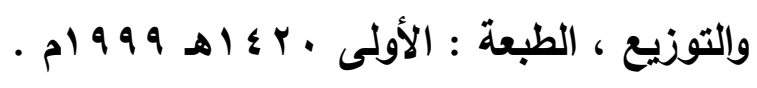

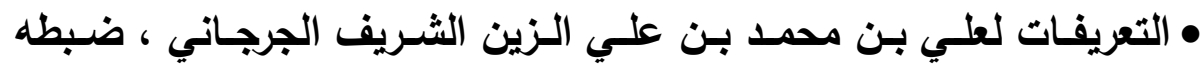

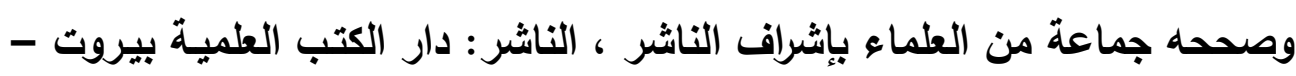

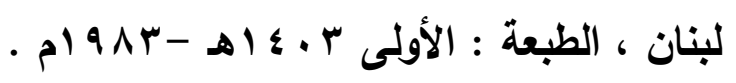

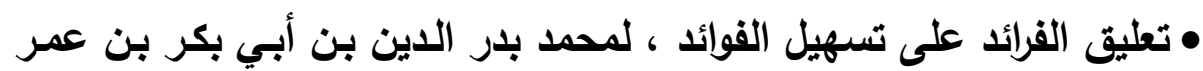
الاماميني ، تحقيق: الدكتور محمد بن عبد الرحمن بن محمد المفدى ، الطبعة :

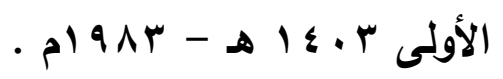

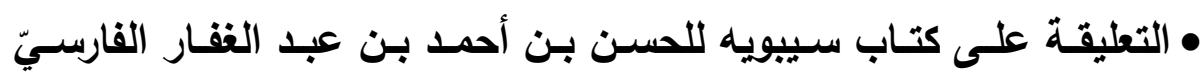

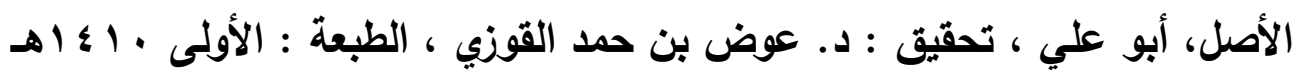
.

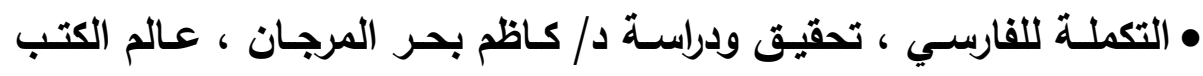

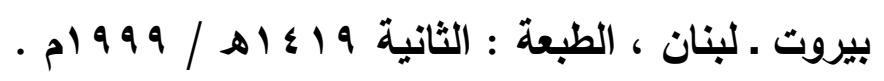

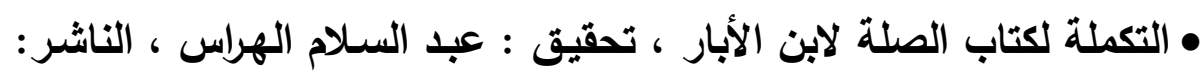

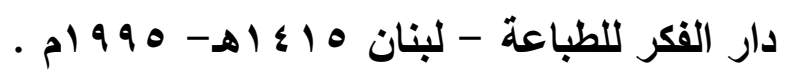


• تمهيد القواعد بشرح تسهيل الفوائد لناظر الجيش ، دراسـة وتحقيق: أ. د. علي محمد فاخر وآخرون ، الناشر: دار السلام للطباعة والنشر والتوزيع والترجمة

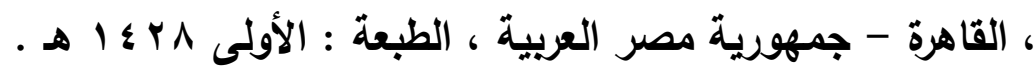
• توجيه اللمع لأحمد بن الحسين بن الخباز ، دراسـة وتحقيق : أ. د. فايز

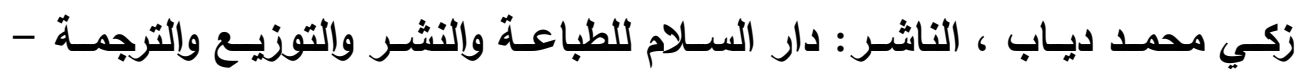

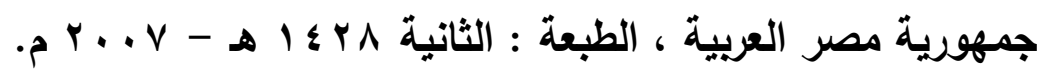
• توضيح المقاصد والمسالكك بشرح ألفية ابن مالك للمرادي المصري المالكي ، شرح وتحقيق : عبد الرحمن علي سليمان ، الناشر : دار الفكر العريب الطبعة :

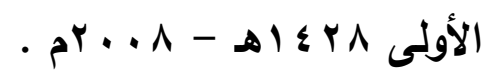

• الجـامع لأحكام القرآن لشـمس الدين القرطبي ، تحقيق : أحمد البردونـي وإبـراهيم أطفـيش ، الناشــر: دار الكتب المصـرية - القـاهرة ، الطبعـة : الثانيـة - $99 \varepsilon-\Delta 1 M \Lambda \varepsilon$ •جامع البيان في تأويل القرآن لأبي جعفر الطبري ، تحقيق : أحمد محمد

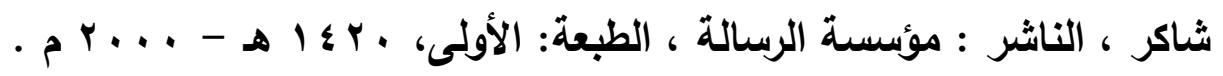
• جامع الاروس العربية لمصطقى بن محمد سليم الغلايينى ، الناشر: المكتبة

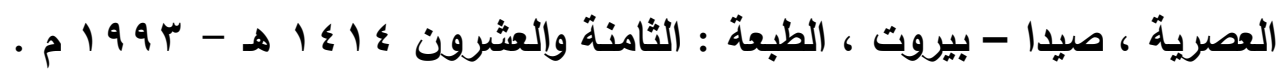
• الجامع الصغير وشرحه النافع الكبير لمن يطالع الجامع الصغير ، مؤلف هـ الجامع الصغير: أبو عبد الله محمد بن الحسن الشيباني ، مؤلف النـافع الكبير: محمد عبد الحي بن محمد عبد الحليم الأنصاري اللكنوي الهندي ، الناشر: عالم

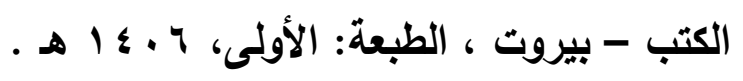
• الجـامع المسـند الصـيح المختصر مـن أمسور رسـول الله صـلى الله عليـه وسلم وسنته وأيامه = صحيح البخاري ، المؤلف: محمد بن إسماعيل أبو عبدالله 
البخـاري الجعفي ، تحقبق : محمـ زهيـر بـن ناصـر الناصـر ، الناشـر: دار طوق النجاة (مصورة عن السلطانية بإضافة ترقيم ترقيم محمد فؤاد عبد الباقي) ، الطبعة

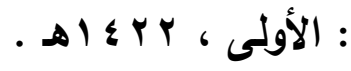

• الجمع بين الصحيحين البخاري ومسلم لمحمد بن فتوح بن عبد الله بن فتوح بن حميد الأزدي الميورقي الحَمِيدي ، تحقيق : د. علي حسين البواب ، الناشر :

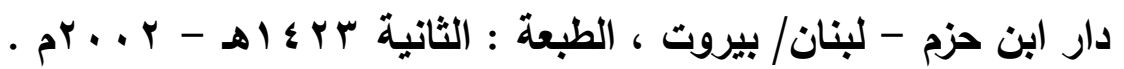
• الجمل في التحو لأبي عبد الرحمن الخليل بن أحمد بن عمرو بن تميم

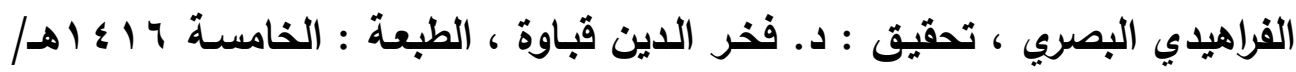
- 1990

• جمهرة اللغة لأبي بكر محمد بن الحسن بن دريد الأزدي ، تحقيق : رمزي

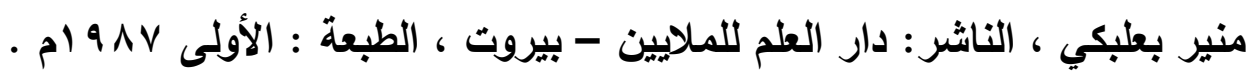
• الجنـى الـاني في حروف المعـاني للمـرادي المصري المـالكي ، تحقيق : د/ فخر الاين قباوة -الأستاذ محمد نديم فاضل ، الناشر: دار الكتب العلمبـة بيروت

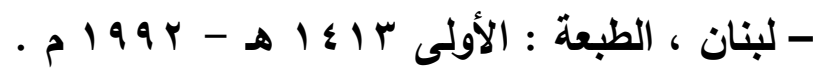
• حاشية الخضري على شرح ابن عقيل على ألفية ابن مالك ـ دار الفكر • • حاثية الصبان على شرح الأثمونى لألفية ابن مالك لأبي العرفان محمد بن علي الصبان الشـافعي ، الناشـر: دار الكتب العلميـة بيروت-لبنـان ، الطبعة :

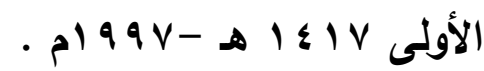

• الحجة في القراعات السبع للحسين بن أحمد بن خالويـه ، تحقيق: د. عبد العال سالم مكرم،الناشر: دار الثروق - بيروت ، الطبعة : الرابعة 1 . ع ا هـ . • الحجة للقراء السبعة للفارسي ، دار المسأمون للتراث بيروت ، ط : الثانبة 
• الحيوان ، المؤلف : عمرو بن بحر بن محبوب الكناني بالولاء الليثي ، أبو

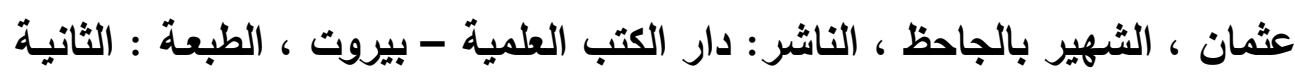
D $1 \leqslant$ \&

• خزانة الأدب ولب لباب لسان العرب لعبد القادر بن عمر البغدادي ، تحقيق وشرح : عبد السـلام محمد هارون ، الناشر: مكتبة الخانجي، القاهرة ، الطبعة :

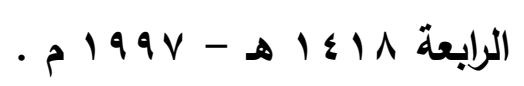

• الخصـائص لأبـي الفتتح عثمـان بـن جنـي الموصـلي ، الناشـر: الهيئة المصرية العامة للكتاب ، الطبعة : الرابعة . • درة الغواص في أوهـام الخواص لأبسي محمد الحريري البصري ، تحقيق : عرفات مطرجي ، الناشـر : مؤسسـة الكتب الثقافيـة - بيروت ، الطبعة : الأولىى، . $\Delta 991 / 1 \leq 11$ • الدرر اللوامـع على هـع الهوامـع شـرح جـع الجوامـع لأحمد بـن الأمسين

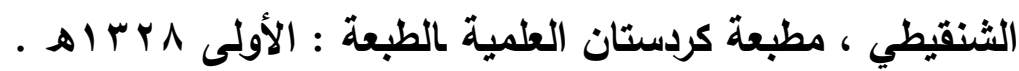
• الدر المصون في علوم الكتاب المكنون للسمين الحلبي ، تحقيق : الدكتور أحمد محمد الخراط ، الناشر : دار القلم ، دمشث . • دستور العلماء ( جامع العلوم في اصطلاحات القنون )، لعبد رب التبي بن

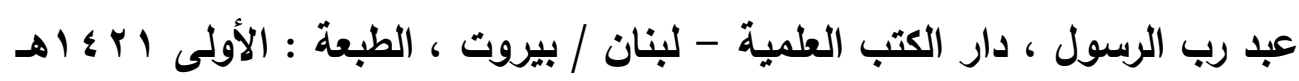
- مr...-

• دلائل الإعجـاز لأبسي بكر عبد القاهر الجرجاني ، تحقيق: محمـود محمــ شـاكر أبو فهر ، الناشر: مطبعة المدني بالقاهرة - دار المدني بجدة ، الطبعة :

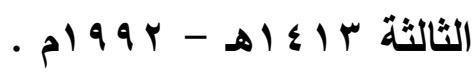


• دليل الطالبين لكلام النحويين المؤلف: مرعي بن يوسف بن أبى بكر بن أحمد الكرمى المقدسي الحنبلى ، الناشر : إدارة المخطوطات والمكتبات الإسـلامية -

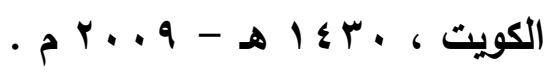

• ديـوان الأخطل ، شـرحه وقدم لـه مهدي محمد ناصـر الدين ، دار الكتب

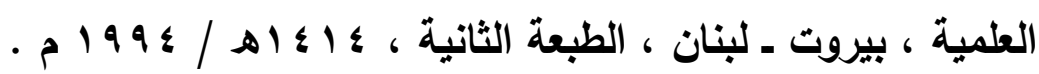

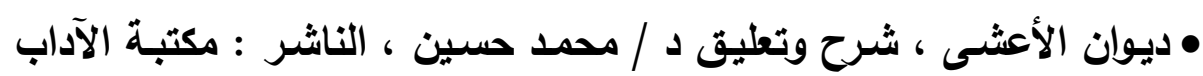
المطبعة النموذجية .

• ديـوان امريع القيس ، اعتنى بـه وشـرحه عبد الكرحمن المصطاوي ، دار

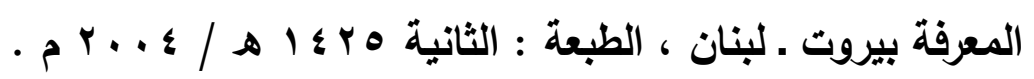
• ديوان أمية بن أبي الصلت ، جمعه وحققه وشرحه د / سميع جميل الجبيلي

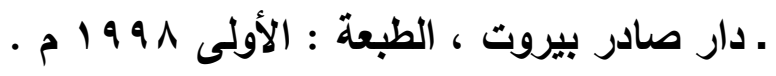

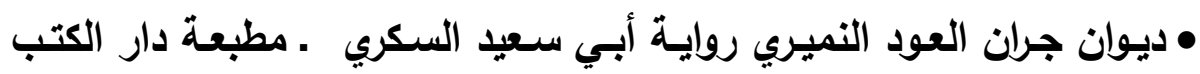

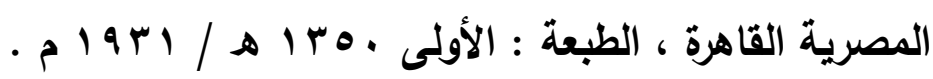
• ديوان جرير بشرح محمد بن حبيب ، تحقيق د/ نعمان محمد أمين طه ،

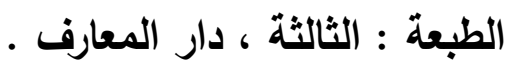
• ديوان حسان بن ثابت ، حققه وعلق عليه د / وليد عرفات ـ دار صـادر

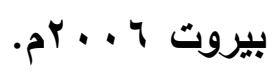
• ديـوان دعبل الخزاعي ، صنعه د / عبد الكريم الأشتر ، الطبعة : الثانيـة

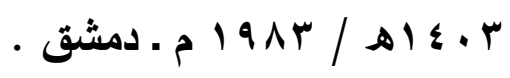
• ديوان ذي الرمة شرح أبي نصر الباهلي روايةة ثُب ، المؤلف: أبو نصر أحمد بن حاتم الباهلي ، تحقيق: عبد القدوس أبو صالح ، الناشر: مؤسسة الإيمان

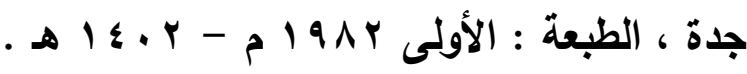




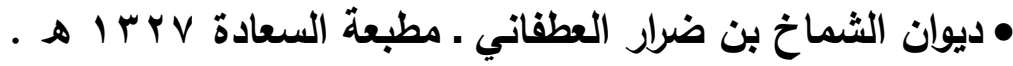
• ديوان الثنفري ، جمعه وحققه وشرحه د / إميل بليع يعقوب ـ الناشر : دار

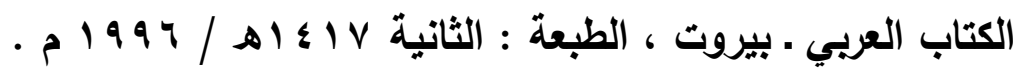
• ديوان عدي بن زيا العبادي ، حققه وجمعه محمد جبار المعبيد 9 ه ام . • ديـوان عمرو بن معد يكرب الزبيـي ، جمعـه ونسقه مطاع الطرابيشـي ،

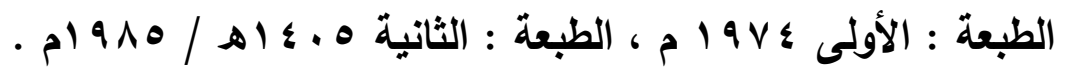
• ديوان الفرزدق ، ضبط معانيه وشرحه إيليا الحاوي ـ دار الكتاب اللبناني

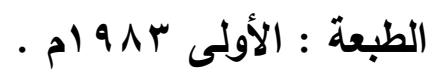
• ديوان مجنون ليلى ، جمع وتحقيق وشرح عبد الستار أحمد فراج ، مكتبة

• ديوان كثير عزة ، جمعه وشرحه د/ إحسان عباس ، دار الثقافة بيروت .

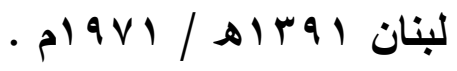
• ديوان لبيد بن ريبعة ، دار المعرفة بيروت ـ لبنان ، اعتنى به حمدو طماس

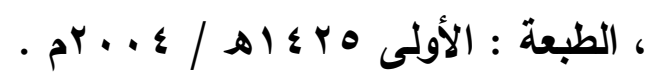

• ديـوان النابغة الذبياني ، اعتخى بـه وشـرحه حمدو طمـاس ، دار المعرفة

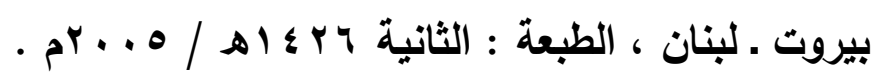

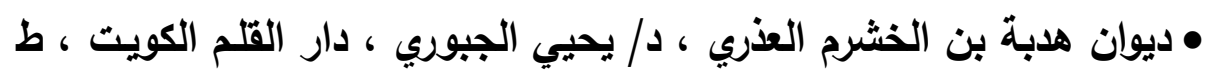

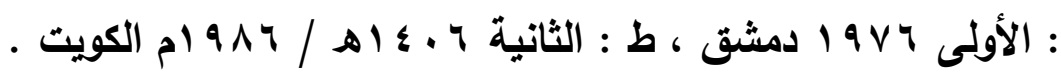
•رسالة الملائكة - نشرها الميمني كملحق في آخر كتابه (أبو العلاء ومـا إلبـه)، المؤلف: أحمد بن عبد الله بن سليمان بن محمد بن سليمان، أبو العلاء المعري ، تحقيق: عبد العزيز الميمني ، دار النشر: دار الكتب العلمية - بيروت / ل

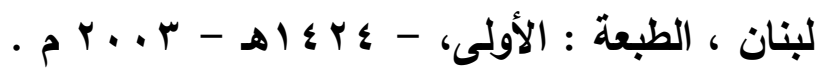


• الروض الأنف في شرح السيرة النبوية لابن هثام لأبي القاسم عبد الرحمن

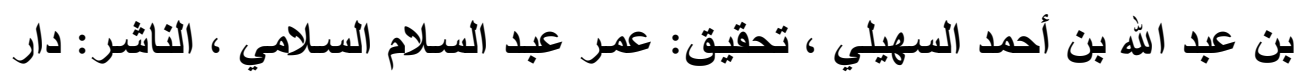

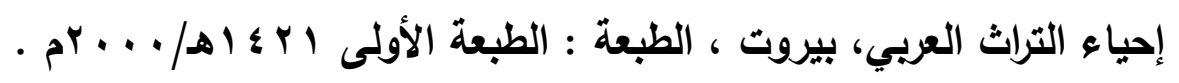

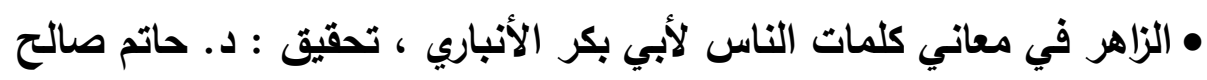

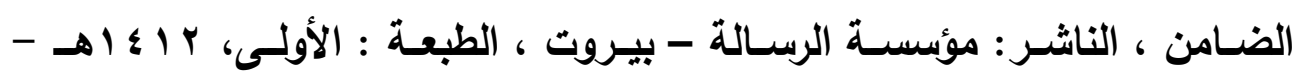
- م) 994

• السبعة في القراءات ، لابن مجاهد البغدادي ، تحقيق : شوقي ضيف ، الناشر : دار المعارف - مصر •

• سر صناعة الإعراب لأبي الفتح عثمان بن جني الموصلي ، الناشر : دار

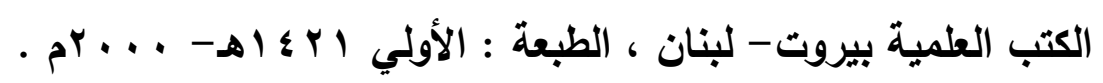

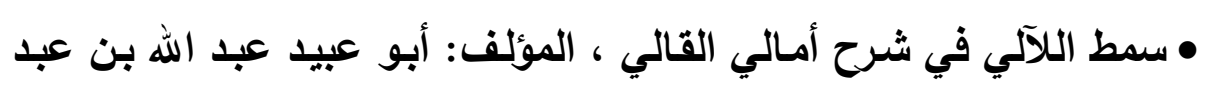

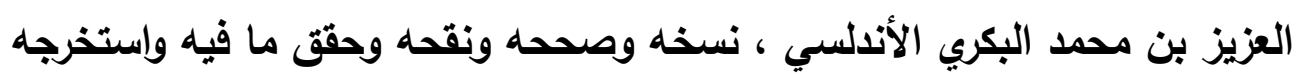

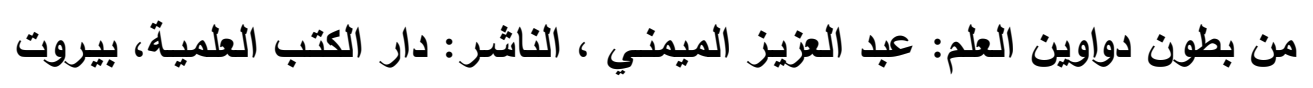

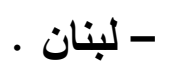

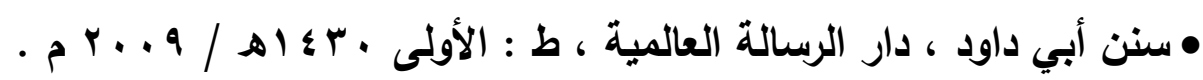

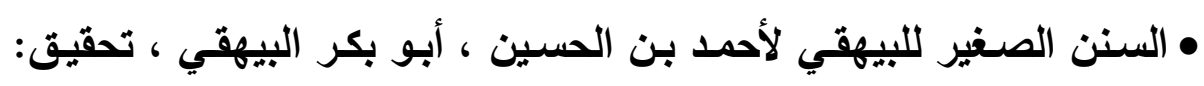

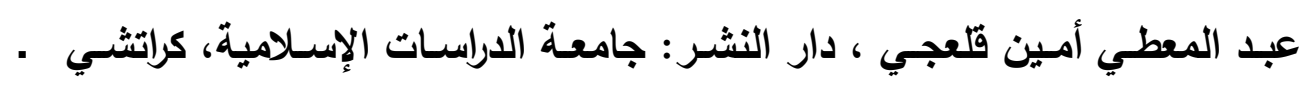

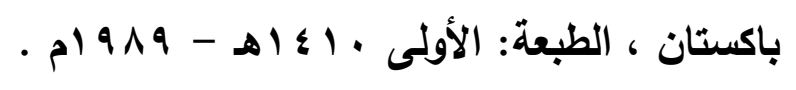

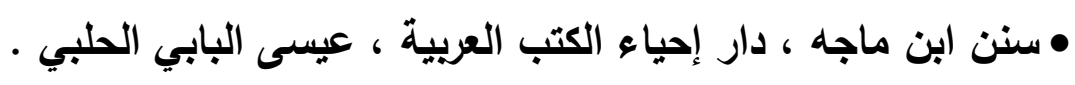

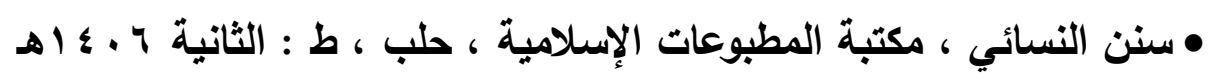
. 9 194/

• شرح الآجرومية ، المؤلف : د حسن بن محمد الحفظي . 


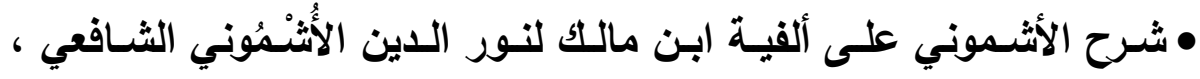

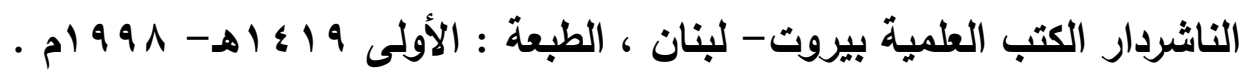

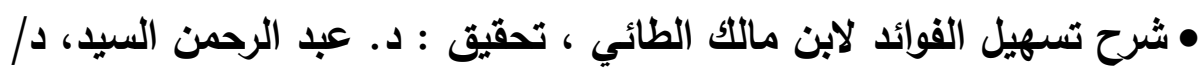
محمد باوي المختون ، الناشر : هجر للطباعة والنشر والتوزيع والإعلان ، الطبعة :

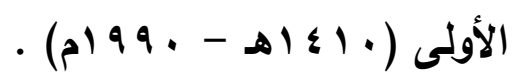

• شرح الجمل الزجاجي لابن عصفور الاثبيلي ، تحقيق د/ صاحب أبو جناح

• شرح ديوان الحماسة للتبريزي ، الناشر: دار القلم - بيروت . • شرح ديوان الحماسة للمرزوفي الأصفهاني ، تحقيق : غريد الشيخ ، وضع ، فهارسه العامة : إبراهيم شمس الدين ، الناشر: دار الكتب العلمية ، بيروت - لبنان

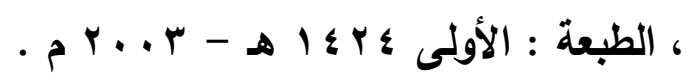

• شرح الرضي على الكافية ، تحقيق يوسف حسن عمر ، جامعة قازيونس

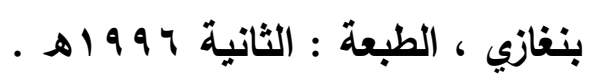
• شرح السنة لأبي محمد الحسين بن مسعود بن محمد بن الفراء البغوي

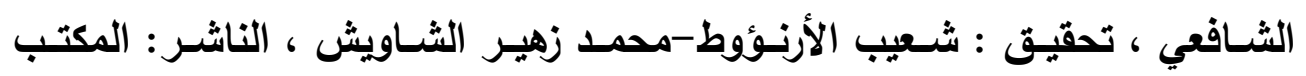

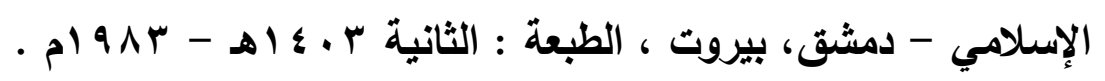
• شـرح شـافية ابـن الحاجب مـع شـرح شـواهده للعـالم الجليـل عبـ القـادر البغدادي صاحب خزانة الأدب ، لمحمد بن الحسن الرضي الإستراباذي ، حققهما ، وضبط غريبهما ، وشرح مبهمهما، الأساتذة : محمد نور الحسن ، محمد الزفزاف ، محمـد محيـى الـدين عبد الحميـ ، الناشـر: دار الكتب العلميـة بيـروت - لبنـان . 19V0- 1990 
• شرح شذور الذهب في معرفة كلام العرب لابن هشـام الأنصاري ، تحقيق: عبد الغتي الدقر ، الناشر : الشركة المتحدة للتوزيع - سوريا . • شـرح شـذور الـذهب في معرفـة كـلام العـرب لثـمس الـدين محمــ بـن عبد المنعم بن محمد الجَوجَري القاهري الشافعي ، المحقق : نواف بن جزاء الحارثي مدرب

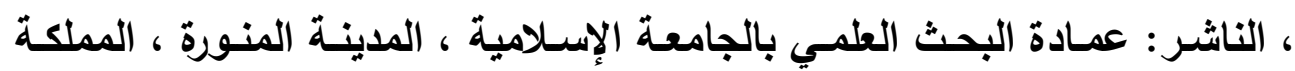

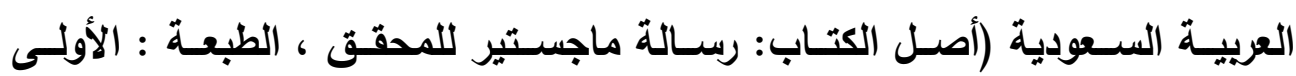
•

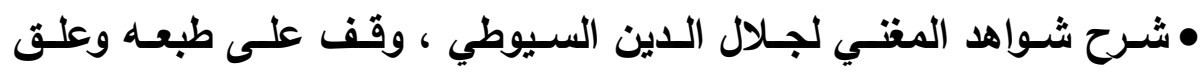
حواشيه : أحمد ظافر كوجان ، مذيل وتعليقات : الشيخ محمد محمود ابن التلاميد

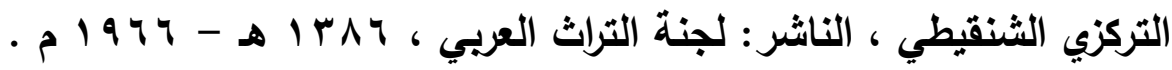
• شرح ابن عقيل على ألفيـة ابن مالك لعبد الله بـن عبد الرحمن العقيلي الهمداني المصري ، تحقيق : محمد محيي الدين عبد الحميد ، الناشر : دار التراث - القاهرة ، دار مصر للطباعة ، سعيد جودة السحار وشركاه ، الطبعة : العشرون .

• شرح قواعد الإعراب لابن هشـام ، المؤليف: محمد بن مصطقى القُوجَوي، شيخ زاده ، دراسة وتحقيق: إسماعيل إسماعيل مروة ، الناشر: دار الفكر المعاصر

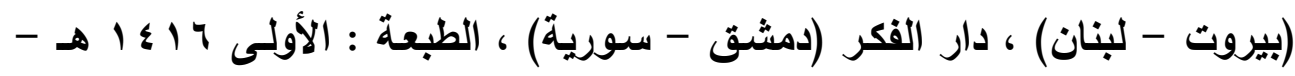
- 1990

• شرح كافية ابن الحاجب لابن جماعة ، تحقيق وتعليق د/ محمد محمد داود

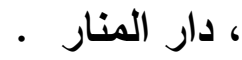


• شـرح الكافيـة الثـافية لابن مالك الطائي الجياني ، تحقيق : عبد المنعم أحمد هريدي ، الناشر: جامعة أم القرى مركز البحث العلمي وإحياء التراث الإسلامي كلية الشريعة والدراسات الإسلامية مكة المكرمة ، الطبعة : الأولى . • شرح كتاب الحدود في التحو لعبد الله بن أحمد الفاكهي النحوي ، تحقيق: د. المتـولي رمضـان أحمــ الـدميري ، الناشـر : مكتبـة وهبـة - القـاهرة ، الطبعـة :

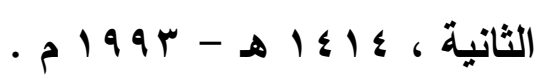

• شرح كتاب سيبويه لأبي سعيد السيرافي ، تحقيق : أحمد حسن مهدلي ، علي سيد علـي الناشـر: دار الكتب العلمية ، بيروت - لبنان ، الطبعة : الأولى . A

• شـرح كتـاب سييويـه (جزء مـن الكتاب (مـن بـاب الندبـة إلى نهايـة بـاب الأفعال) حُقِّق كرسـالة دكتوراه) لأبسي الحسن علـي بن عيسـى الرمساني ، أطروحـة دكتوراة لد: سيف بن عبد الرحمن بن ناصر العريفي ، إشراف: د تركي بن سهو

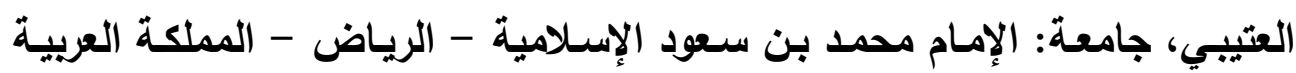

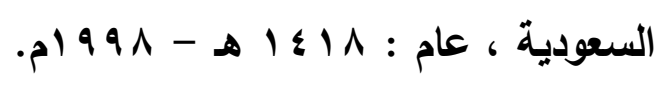

• شرح كتاب سيبويه للسيرافي ، رسالة دكتوراة بكلية اللغة العربية ـ جامعة مامة الأزهر بالقاهرة ـ تحقيق د / دردير محمد أبو السعود . • شرح المفصل للزمخشري لابن يعيش ، أبو البقاء ، موفق الدين الأسدي الموصلي ، قدم لـه : الدكتور إميل بـيع يعقوب ، الناشـر: دار الكتب العلميـة ،

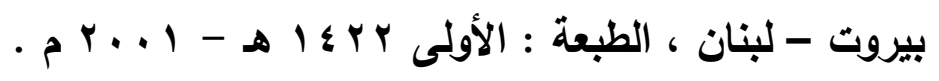

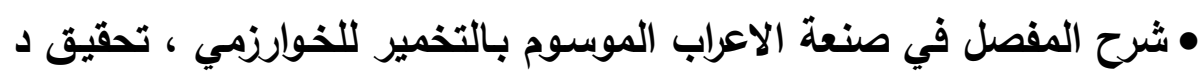
/ عبد الرحمن بن سليمان العثيمين ، دار الغرب الاسدلامي • 
• شرح المقدمة الجزولية الكبيز للثـلوبين مؤسسـة الرسـالة ، ط : الثانية - 1998

•شـرح المقدمـة المحسبة لطـاهر بـن أحمــ بـن بابثـاذ ، تحقيـق : خالــا

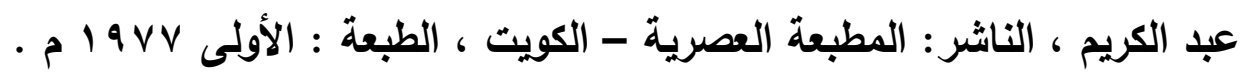

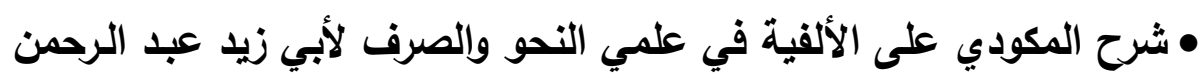

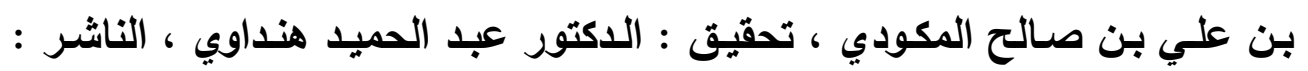

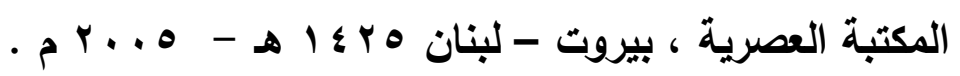

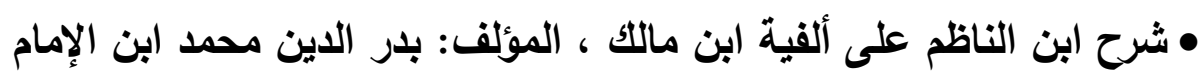

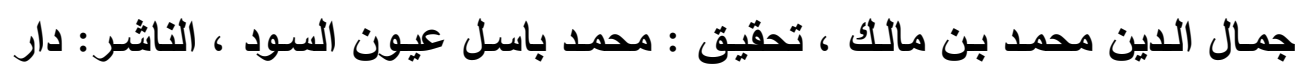

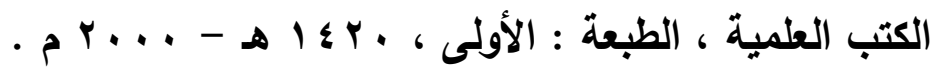

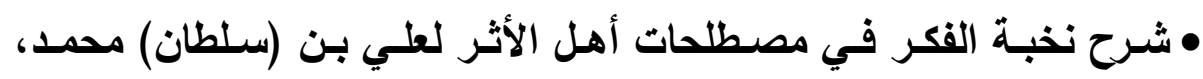

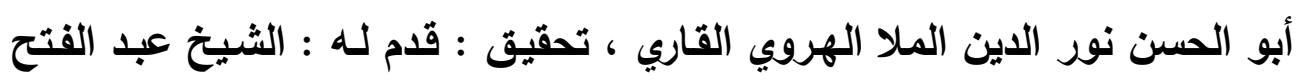

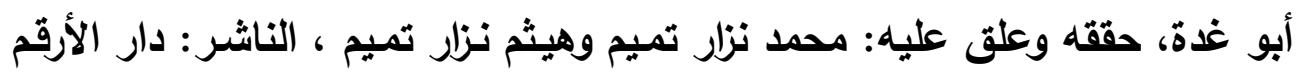

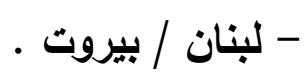

• شرح نقائض جرير والفرزدق لأبي عبيدة معمر بن المثنى ، تحقيق : محمد

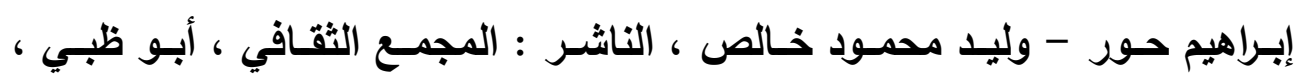

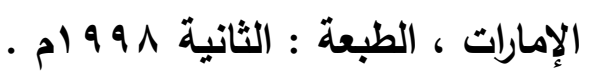

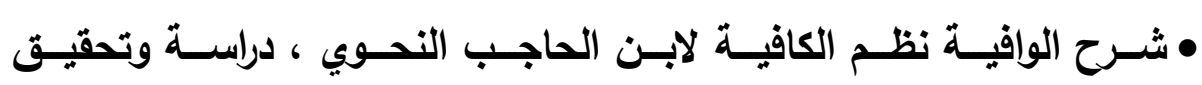

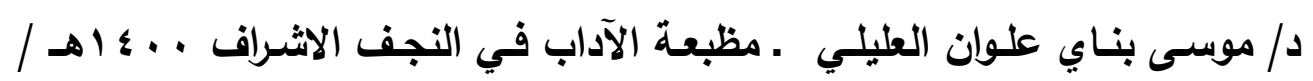
. 


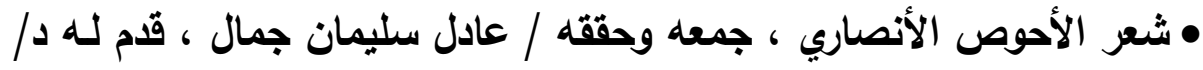

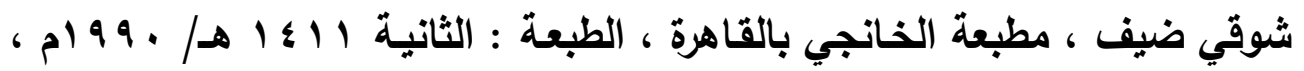

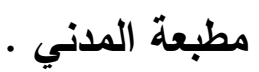
• الشعر والشعراء ، أبو محمد عبد الله بن مسلم بن قتيبة الدينوري ، الناشر: دار الحديث ، القاهرة بr ؛ 1 هـ . • الصاحبي في فقه اللغة العربية ومسائلها وسنن العرب في كلامها لأحمد ابن فارس بن زكرياء القزويني الرازي ، الناشر: محمد علي بيضون ، الطبعة الأولى م) $99 V-\infty 1 \leq 11$ • الصحاح تاج اللغة وصحاح العربية لأبي نصر إسماعيل بن حماد الجوهري

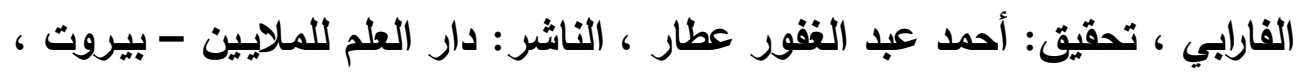

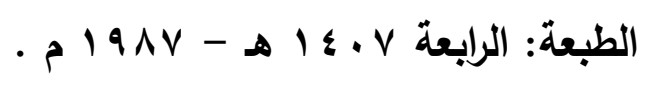

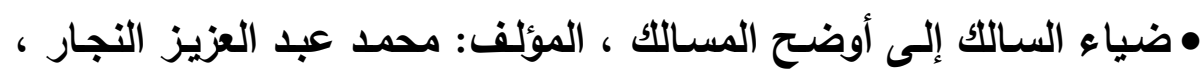

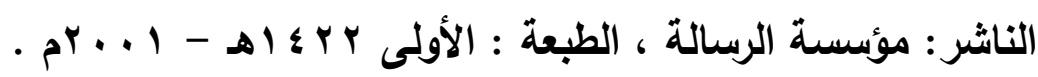
• الطبقات الكبرى ، القسم المتمم لتابعي أهل المدينة ومـن بعدهم ، المؤلف: أبو عبد الله محمد بن سعد بن منيع الهاشمي بالولاء، البصري، البغدادي المعروف بابن سعد ، تحقيق : زياد محمد منصور ، الناشر : مكتبة العلوم والحكم - المدينة

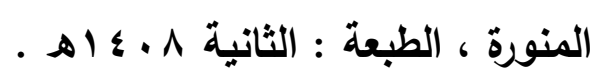

• العقد الفريد لأحمد بن عبد ربـه الأندلسي ، تحقيق د/ مفيد محمد قميحة .

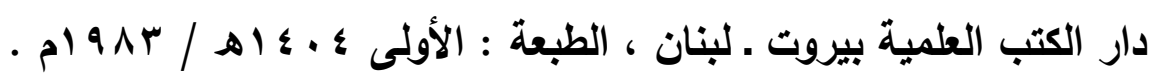

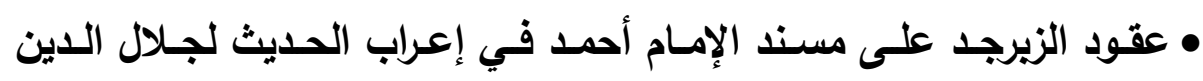
السـيوطي ، تحقيق : حسن موسـى الثـاعر ، الناشـر : مجلـة الجامعـة الإسـلامية الإملة بالمدينة المنورة . 
• عمدة الكتاب لأبي جعفر النََّّاس ، تحقيق : بسام عبد الوهاب الجابي ، دابل

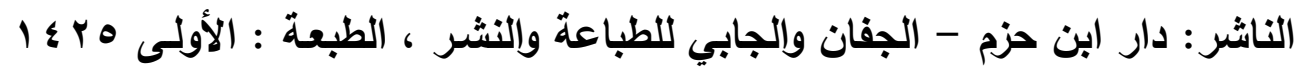

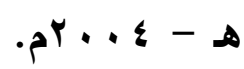

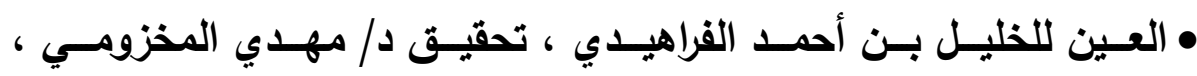
د/ إبراهيم السامرائي ، دار ومكتبة الهلال .

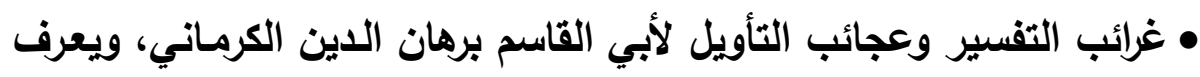

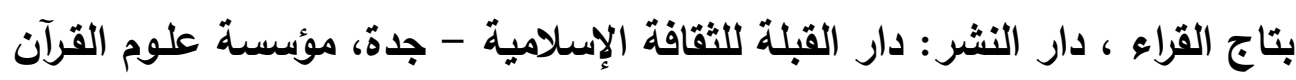
- بيروت . • غريب الحديث ، المؤلفف: أبـو سـليمان حمد بـن محمـد بـن إبراهيم بـن

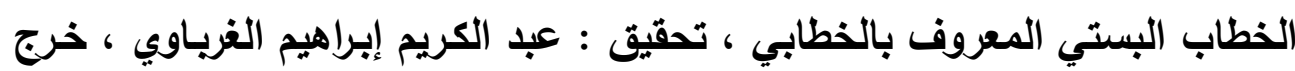

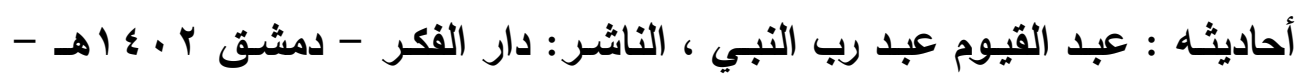
. plakr

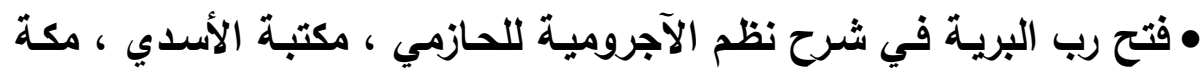

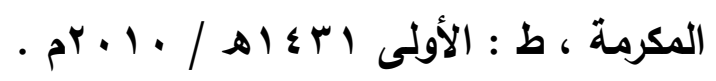

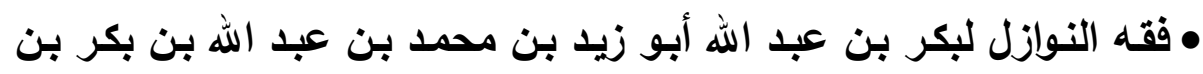

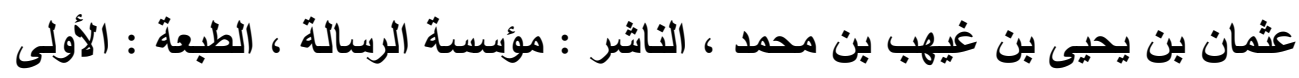

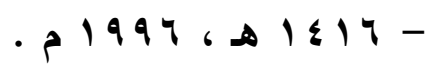
• الكافية في علم النحو لابن الحاجب ، تحقيق : الاكتور صالح عبد العظيم

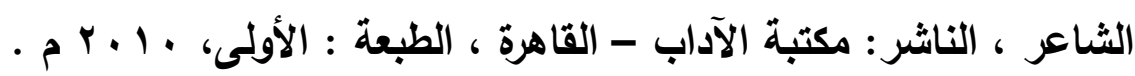

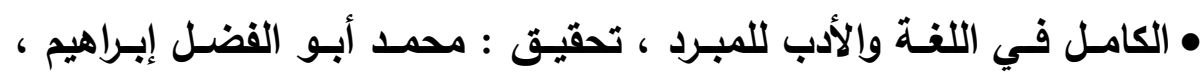

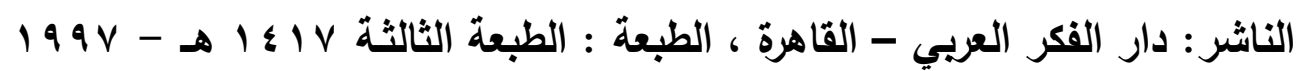


• الكتاب لسييويه ، تحقيتق : عبد السـلام محمد هـارون ، الناثـر: مكتبـة

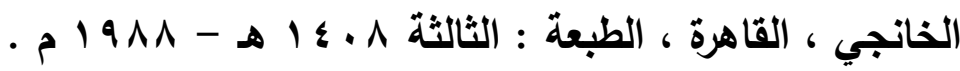

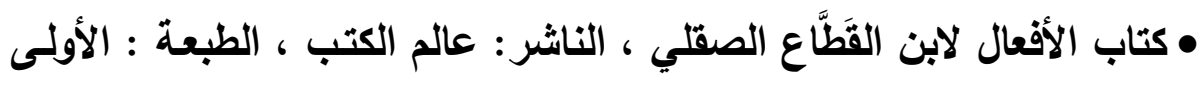

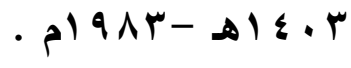
• كتاب اللامـات للزجاجي ، تحقيق مـازن المبارك ـ دار الفكر ـ دمشق ،

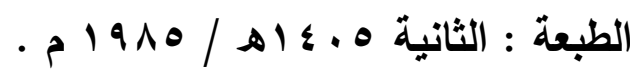
• الكثـاف عن حقائق غوامض التنزيل للزمخثري جار الله ، الناشـر: دار

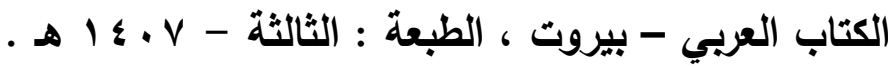

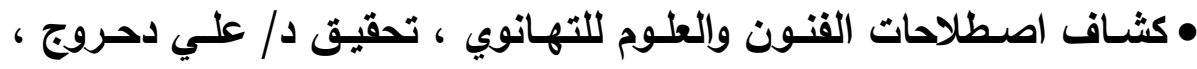

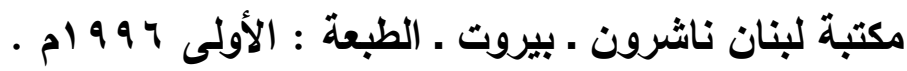
• كثف الخفاء ومزيل الإلباس لإسماعيل بن محمد بن عبد الهادي الجراحي

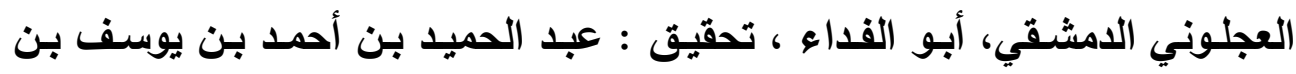

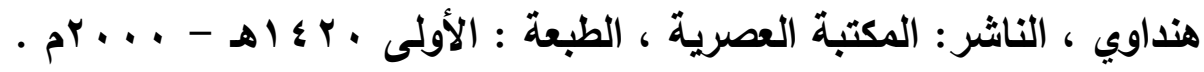

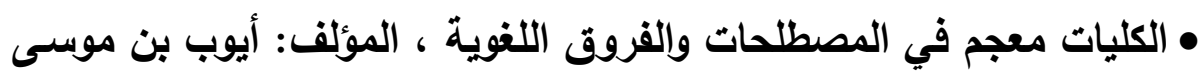

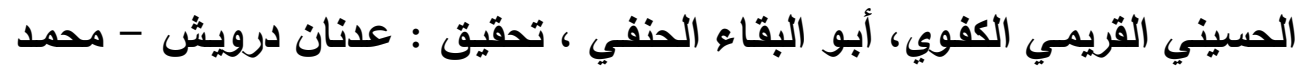

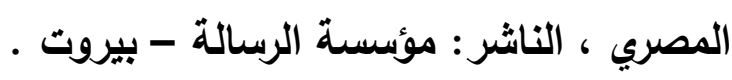

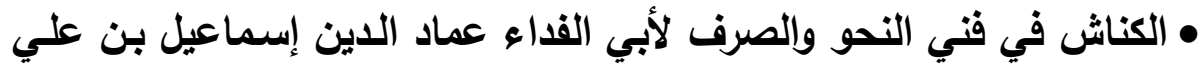
ابن محمود بن محمد ابن عمر بن شاهنشـاه بن أيوب ، دراسـة وتحقيق : الدكتور

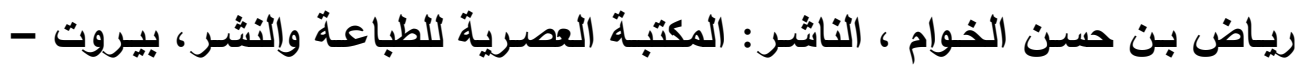

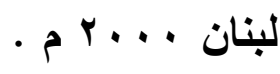


• ابن كيسـان النحوي ، رسـالة مقدمـة لنيل درجة الماجستير ، إعداد محمد

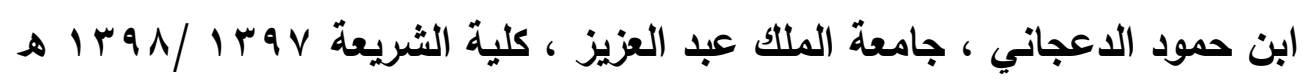
- 19V^/19VV

• اللباب في علل البناء والإعراب لأبي البقاء العكبري ، تحقيق: د.

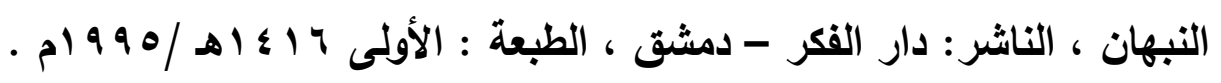

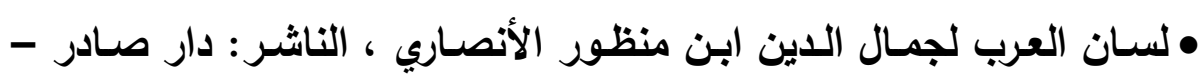

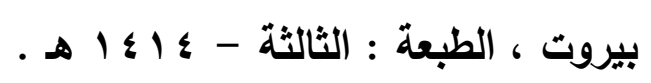
• لسان المحدثين تأليف محمد خلف سلامة ، تم نشره في ملتقى أهل الحديث $r^{r} \cdot \cdot v$

• اللمحة في شرح الملحة ، المؤلف: محمد بن حسن بن سِباع بن أبي بكر الجذامي، أبو عبد الله، شمس الدين، المعروف بابن الصائغ ، تحقيق : إبراهيم بن

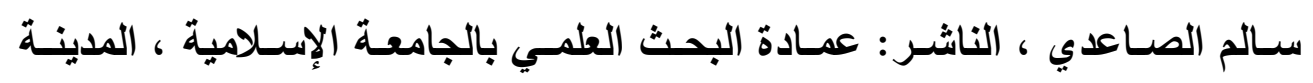

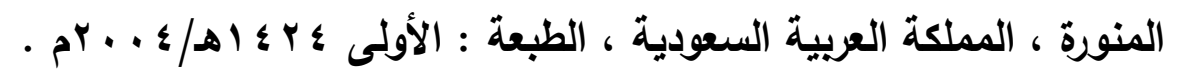
• اللمع في العربية لأبي الفتح عثمان بن جني الموصلي ، تحقيق : فائز فارس ، الناشر : دار الكتب الثقافية - الكويت . • مجالس ثعلب لأحمد بـن يحيـى بن زيــ بـن سيار الثيباني بـالولاء، أبو

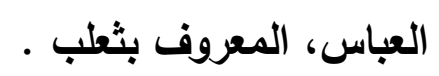
• مجلـة لسـان العـرب ، العدد الثـامن والأريعون ، الربـاط ـ مطبعة النجـاح

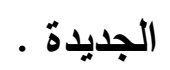

• مجمـع الأمثال للميداني النيسـابوري ، تحقيق : محمد محيـى الدين عبد

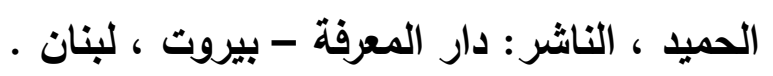


• مجمع الزوائد ومنبع الفوائد لنور الاين الهيثمي ، تحرير الحافظين العراقي وابن حجر ، الطبعة : الثانية V 99 و م ، دار الكتاب العربي • بيروت .

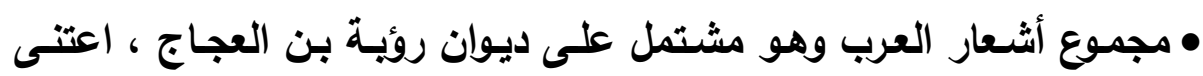
بتصحيحه وترتيبه وليم بن الورد ، دار ابن قتيبة ـ الكويت . • المحتسب في تبيين وجوه شواذ القراءات والإيضاح عنها لأبي الفتح عثمان بن جني الموصلي ، الناشر : وزارة الأوقاف-المجلس الأعلى للشئون الإسـلامية ،

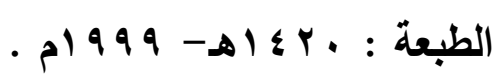

• المحرر الوجيز في تفسير الكتاب العزيز لابن عطية الأندلسي المحاريي ،

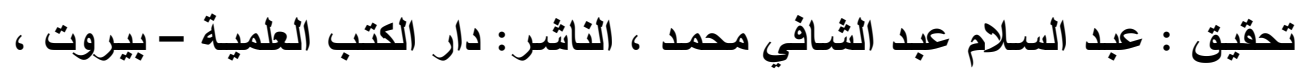

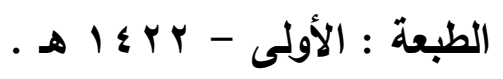
• المحكم والمحيط الأعظم ، المؤلف: أبو الحسن علي بن إسماعيل بن سيده المرسسي ، تحقيق : عبد الحميد هنداوي ، الناشر: دار الكتب العلمية - بيروت ،

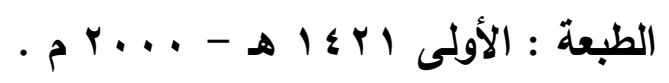
• المدارس النحوية لشوقي ضيف ، الناشر: دار المعارف . • المذكر والمؤنث ، المؤلف: سعيد بن إبراهيم التستري، البغدادي، النصراني،

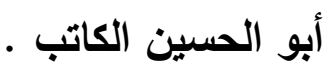
• مرآة الجنان وعبرة اليقظان في معرفة مـا يعتبر من حوادث الزمـان لأبي محمد عفيف الاين عبد الله بن أسعد بن علي بن سليمان اليافعي ، وضع حواشيه:

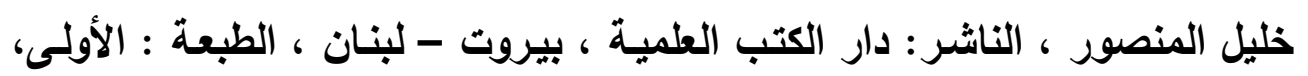
- $199 \mathrm{~V}-\Delta 1 \leq 1 \mathrm{~V}$ • المرتجل لابن الخشـاب ، تحقيق ودراسـة : علي حيدر (أمين مكتبة مجمع

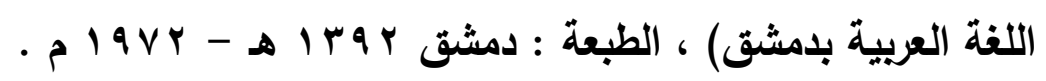


• المزهر في علوم اللغة وأنواعها لجلال الاين السيوطي ، تحقيق : فؤاد علي

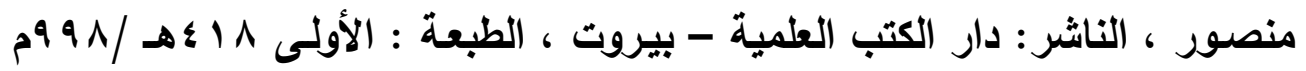

• المسائل البصريات لأبي علي الفارسي ، تحقيق : د. محمد الشاطر أحمد

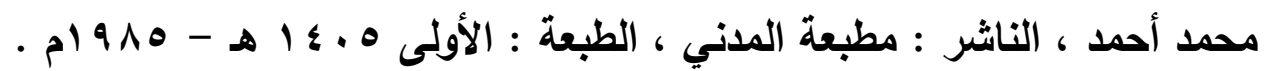
• المساعد على تسهيل الفوائد لابن عقيل ، تحقيق د / محمد كامل بركات ،

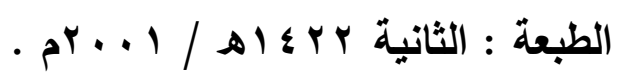

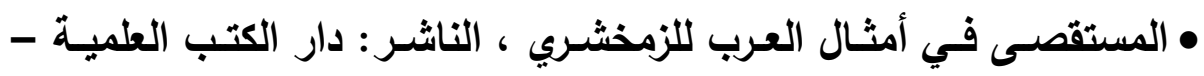

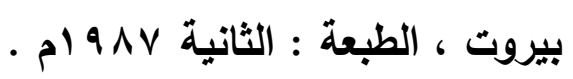
• مسند الإمـام أحمد بن حنبل ، المؤليف: أبو عبد الله أحمد بن محمد بن حنبل بـن هـلال بـن أسـد الثـيباني ، تحقيق : أحمد محمد شـاكر ، الناشـر : دار

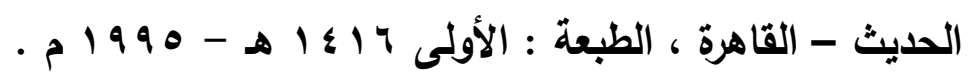
• مسند الحميدي ، المؤلف: أبو بكر عبد الله بن الزبيز بن عيسى بن عبيد الله القرشي الأسدي الحميدي المكي ، حقق نصوصسه وخرج أحاديثه : حسن سليم أسد الآَّرَانيّ ، الناشر: دار السقا، دمشث - سوريا ، الطبعة : الأولى 999 الألى 19 م. • مسند الإمـام الثـافعي للشـافعي ، رتبـه على الأبواب الفقهية : محمد عابـ السندي ، عرف للكتاب وترجم للمؤلف : محمد زاهد بن الحسن الكوثري ، تولى ، نشره وتصحيحه ومراجعة أصوله على نسختين مخطوطتين : السيد يوسف علي

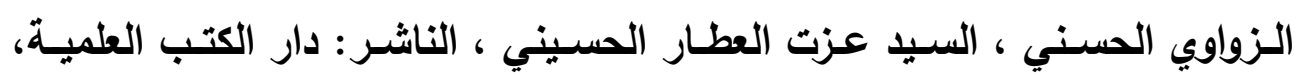

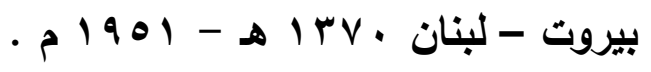


• المسند الصحيح المختصر بنقل العدل عن العدل إلى رسول الله صلى الله عليه وسلم ، المؤلف : مسلم بن الحجاج أبو الحسن القشيري النيسابوري ، تحقيق : محمد فؤاد عبد الباقي ، الناشر : دار إحياء التراث العربي - بيروت . • مصابيح السنة لأبي محمد الحسين بن مسعود بن محمد بن الفراء البغوي الثافعي ، تحقيق : الاكتور يوسف عبد الرحمن المرعثلي ، محمد سليم إبراهيم

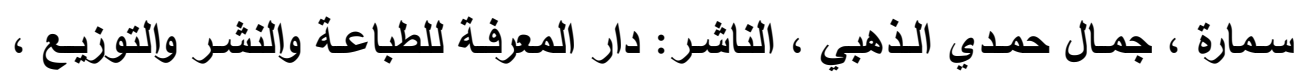

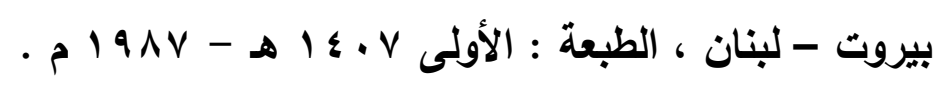

• معالم السنن ، وهو شرح سنن أبي داود ، المؤلف : أبو سليمان حمد بن محمد بن إبراهيم بن الخطاب البستي المعروف بالخطابي ، الناشر : المطبعة العلمية

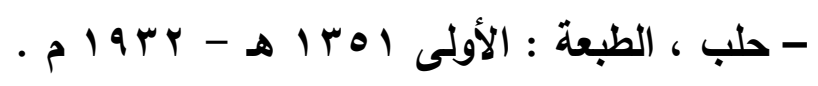

• معاني القراءات للأزهري ، المؤلف: محمد بن أحمد بن الأزهري الههري أبو ه منصور ، الناشر: مركز البحوث في كلية الآداب - جامعة الملك سعود ، المملكة

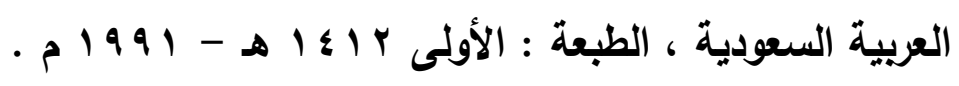

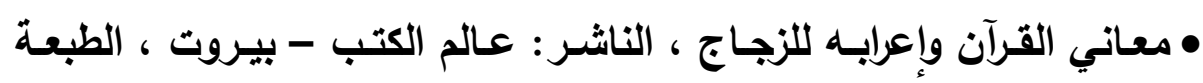

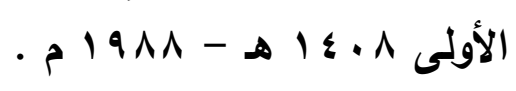

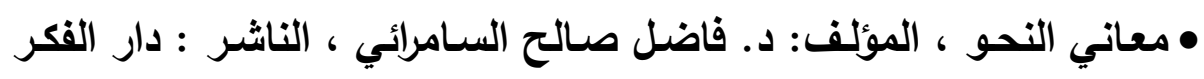

للطباعة والنشر والتوزيع - الأردن ، الطبعة : الأولى ، ، بـ 1 هـ - . . . ب م .

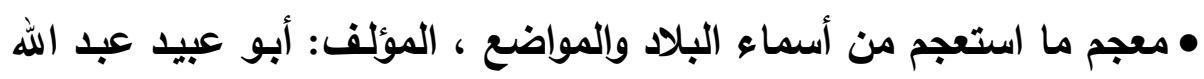

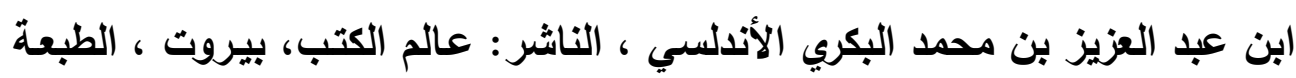

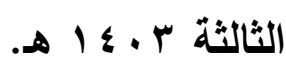

• مغني اللبيب عن كتب الأعاريب لابن هشام ، تحقيق : د. مـازن المبارك، محمد علي حمد الله ، الناشر: دار الفكر - دمشث ، الطبعة : السادسة هـ 9 ام . 
• مفتاح العلوم للسكاكي الخوارزمي ، ضبطه وكتب هوامشـه وعلق عليه : نعيم زرزور ، الناشـر : دار الكتب العلميـة ، بيـروت - لبنـان ، الطبعـة : الثانيـة

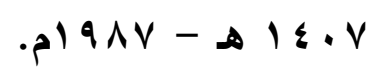

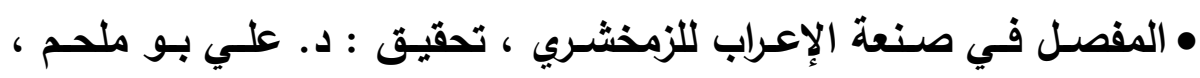
الناشر: مكتبة الهلال - بيروت ، الطبعة : الأولى به 9 ام .

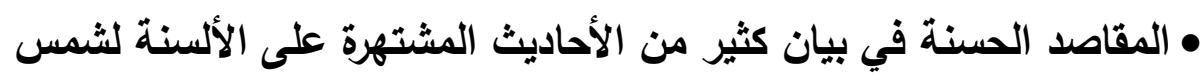
الدين السـخاوي ، تحقيق : محمد عثمـان الخشت ، الناشر : دار الكتاب العريسي -

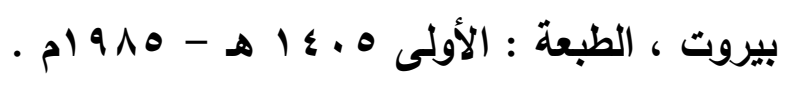
• المقاصد الثافية في شرح الخلاصة الكافية (شرح ألفية ابن مالك) للشاطبي ، تحقيـق : مجموعـة محققين وهــ : الجـزع الأول/ د. عبد الـرحمن بـن سـليمان

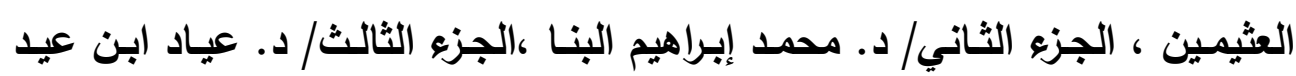

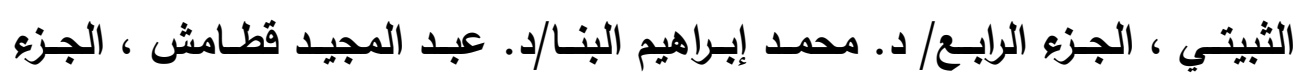
الخامس/د. عبد المجيد قطامش ، الجزع السـاد//د. د. عبد المجيد قطامش الجزع السابع/د. محمد إبراهيم البنا/د. سليمان بن إبراهيم العايد/د. السيد تقي ، الجزيع الثامن/ د. محمد إبراهيم البنا ، الجزع التاسع/د. محمد إبراهيم البنا ، الناشر : معهد البحوث العلمية وإحياء التراث الإسـلامي بجامعة أم القرى - مكة المكرمة ، الطبعة

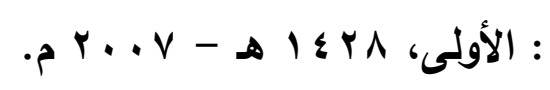

• المقتضـب للمبـرد ، تحقيـق : محمـد عبد الخـالق عظيمـة ، الناشـر: عـالم

$$
\text { الكتب - بيروت }
$$

• المقـرب لابـن عصـفور ، تحقيـث أحمــ عبــ السـتار الجـواري ، عبــ الله

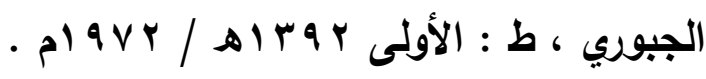


• المقصور والممدود لابن ولاد ، تحقيق : بولس برونله ، الناشر : مطبعة

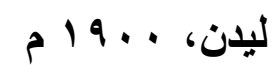

• نثـأة النحو وتاريخ أثـهر النحاة للثيخ محمد الطنطاوي . رحمـه الله . ،

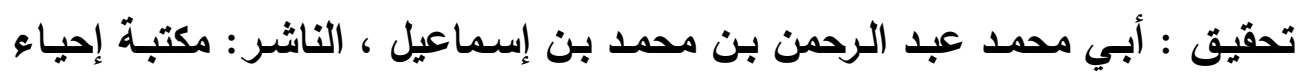

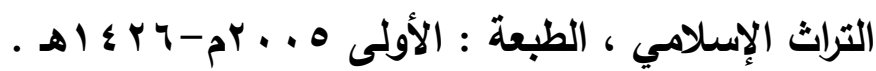

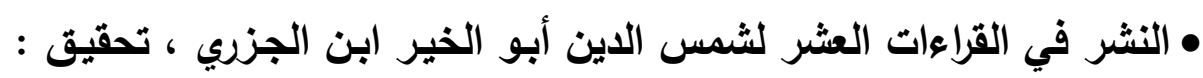

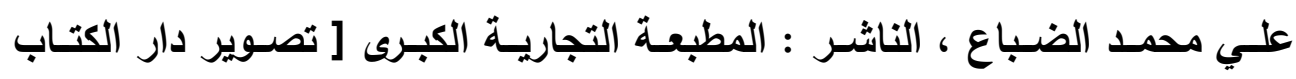

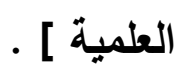
• النكت في تفسير كلام سييويه للأعلم الثنتمري ، دراسـة وتحقيق الأستاذ

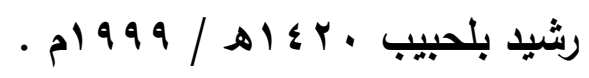

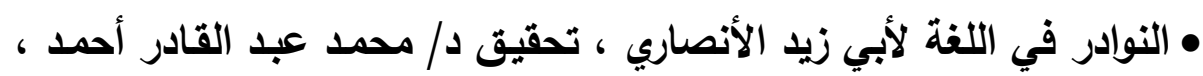

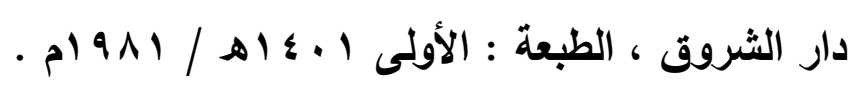

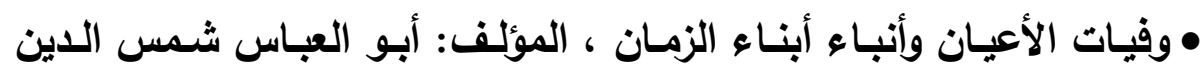

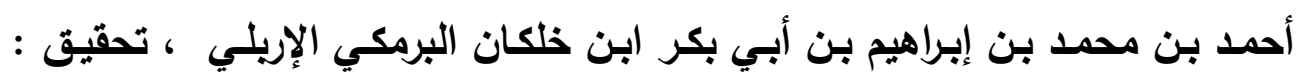

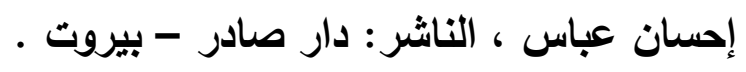

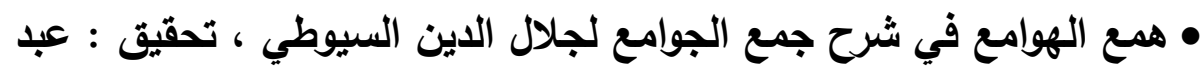

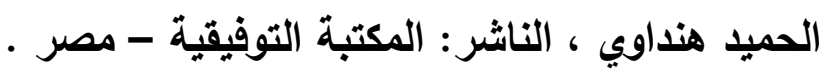

